Sara J. Casare

\title{
Uma Ontologia Funcional de Reputação para Agentes
}

Texto apresentado à Escola Politécnica da Universidade de São Paulo para a obtenção do título de Mestre em Engenharia Elétrica

São Paulo

2005 
Sara J. Casare

\section{Uma Ontologia Funcional de}

\section{Reputação para Agentes}

Texto apresentado à Escola Politécnica da Universidade de São Paulo para a obtenção do título de Mestre em Engenharia Elétrica

Área de Concentração:

Sistemas Digitais

Orientador:

Prof. Dr. Jaime Simão Sichman

São Paulo 
FICHA CATALOGRÁFICA

\section{Casare, Sara J.}

Uma ontologia funcional de reputação para agentes / S.J. Casare. -- São Paulo, 2005.

$170 \mathrm{p}$.

Dissertação (Mestrado) - Escola Politécnica da Universidade de São Paulo. Departamento de Engenharia de Computação e Sistemas Digitais.

1.Inteligência artificial 2.Sistemas multiagentes I.Universidade de São Paulo. Escola Politécnica. Departamento de Engenharia de Computação e Sistemas Digitais Il.t. 
Ao Andrei 
Quem já não se sacrificou alguma vez - pela própria reputação?

Friedrich Nietzsche, Além do bem e do mal. 


\section{Agradecimentos}

Eu gostaria de agradecer:

Ao professor Sigmar Malvezzi, do Instituto de Psicologia da USP, pela atenção e pelas importantes indicações bibliográficas no campo da Psicologia Social.

Ao professor Alexis Drogoul, da Universidade de Paris VI, pela acolhida no Laboratório de Inteligência Artificial - LIP 6 - durante os meses de janeiro, fevereiro e março de 2004, que proporcionou o meu acesso às suas aulas, à biblioteca, aos seminários promovidos pelo Laboratório, assim como a convivência com pesquisadores franceses.

Aos professores Anna Helena Reali Costa e Edson Satoshi Gomi, da Escola Politécnica da USP, pelos seus importantes comentários e sugestões no meu exame de qualificação.

Ao professor Jaime Simão Sichman, meu orientador no programa de mestrado. Agradeço ao Jaime pela sugestão do tema deste trabalho, pelo seu apoio e disponibilidade durante os quase três anos que me foram necessários para desenvolvê-lo, pelas suas várias e sempre criteriosas revisões deste texto, pela compreensão de minhas limitações de tempo e, finalmente, pela oportunidade de escrever dois artigos em co-autoria.

Aos meus colegas do Laboratório de Técnicas Inteligentes, em especial a Maria das Graças Bruno Marietto, pelas oportunidades de diálogo e por sua disponibilidade para responder minhas inúmeras questões.

Aos meus gerentes na IBM, Gustavo Cameira e Eduardo Villela, que concordaram com meu afastamento do trabalho por um ano, sem o qual a realização deste trabalho não teria sido possível.

Aos meus colegas e mentores na IBM, em especial ao Jéferson Soares e à Miriam Caçador, que incentivaram e apoiaram minha decisão de voltar aos bancos de escola.

Aos meus pais, pelo seu apoio sempre incondicional e sua compreensão pelas minhas raras viagens a Fernandópolis nos últimos dois anos. 


\section{Resumo}

Esta dissertação propõe uma Ontologia Funcional de Reputação para agentes. Tal ontologia representa uma parte do conhecimento científico sobre reputação provido tanto pelas Ciências Humanas quanto pelos trabalhos em Inteligência Artificial. Seu objetivo é oferecer uma perspectiva funcional para a representação e análise da reputação como mecanismo de controle social em sociedades de agentes, de forma a sustentar a implementação de modelos de reputação para agentes. A perspectiva funcional adotada consiste em considerar que os conceitos que compõem a ontologia são agrupados em categorias, de acordo com a sua função no mecanismo de controle social. A Ontologia Funcional de Reputação foi construída a partir das categorias de conhecimento da Ontologia Funcional do Direito, proposta por Valente (1995), e é composta por cinco categorias de conhecimento: Conhecimento Reputativo, Conhecimento Normativo, Conhecimento de Responsabilidade, Conhecimento do Mundo e Conhecimento de Senso Comum. A categorização de conceitos definida para o mundo jurídico é utilizada para a representação do mundo social, por meio da extensão do conceito de norma jurídica em norma social e da interiorização do mecanismo de controle social. A ontologia foi codificada em OWL, uma linguagem formal baseada em lógica descritiva. Uma vez construída a ontologia, os conceitos utilizados por diversos modelos e sistemas de reputação foram utilizados na sua avaliação. A utilização de um motor de inferência permitiu comparar estes conceitos, representados por meio de classes OWL, com as classes da ontologia. Tal comparação permite avaliar, de modo preliminar, a adequação do uso da Ontologia Funcional de Reputação como uma possível interlingua entre diversos agentes heterogêneos, cada qual utilizando um modelo de reputação diferente, que necessitam interoperar. 


\section{Abstract}

This work presents a Functional Ontology of Reputation for agents. This ontology represents the broad knowledge about reputation produced in some areas of interest such as Social Sciences and Artificial Intelligence. Its goal is to provide a functional perspective both to represent and analyze reputation as a social control mechanism for agent's societies, in order to support the implementation of reputation model for agents. The Functional Ontology of Reputation employs the primitive categories of knowledge used in the Functional Ontology of Law proposed by Valente (1995). The idea is that the concepts of the legal world can be used to model the social world, through the extension of the concept of legal rule to social norm and the internalization of social control mechanisms in the agent's mind, so far externalized in legal institutions. The Functional Ontology of Reputation contains five main categories that have been borrowed from or inspired by the Functional Ontology of Law: Reputative Knowledge, Responsibility Knowledge, Normative Knowledge, World Knowledge and Common Sense Knowledge.

As in the Functional Ontology of Law, the distinction among the categories of the reputation ontology are accomplished according to a functional perspective, in which each component of the reputation system, embedded in the social system, exists to perform a specific function in the effort to achieve social objectives, such as trust, reciprocity and social cooperation. The Functional Ontology of Reputation was implemented in OWL, a description logic language. This ontology was evaluated by using several concepts related to reputation, included in different reputation models and reputation systems. These concepts were defined as OWL classes and a reasoner was used in order to produce the comparison between these concepts and the ontology classes. This comparison allows evaluating, in a preliminary way, the Functional Ontology of Reputation utilization as a possible interlingua between several heterogeneous agents that need to interoperate, despite the utilization of different reputation model. 


\section{Sumário}

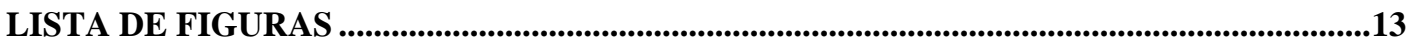

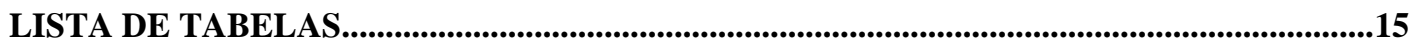

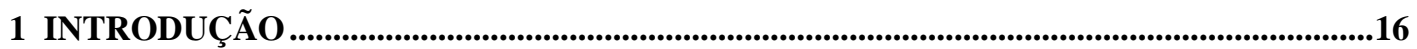

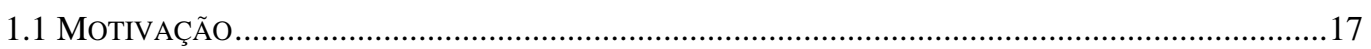

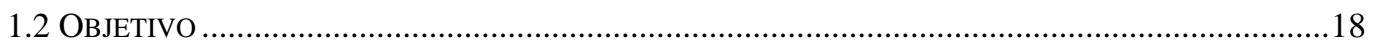

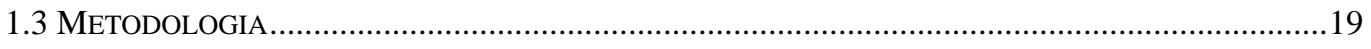

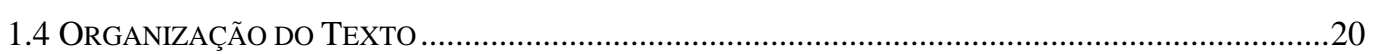

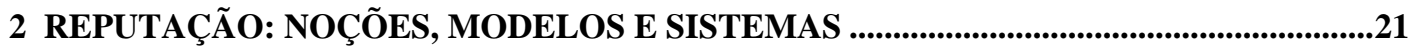

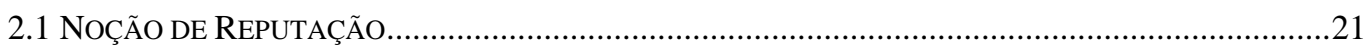

2.1.1 Reputação como Objeto da Psicologia .......................................................................22

2.1.2 Formação da Reputação.........................................................................................22

2.1.3 Reputação, Auto-Imagem, Auto-Estima e Comportamento ............................................23

2.1.4 Rede Social e Rede de Reputação...................................................................................24

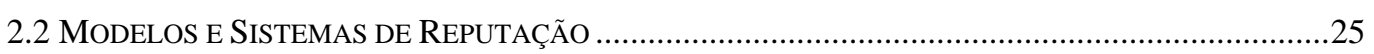

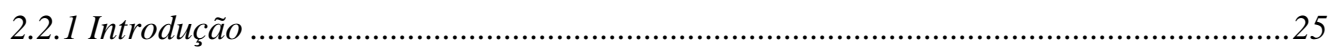

2.2.2 Modelo Cognitivo de Reputação de Conte e Paolucci (2002).........................................26

2.2.3 Modelo Tipologia de Reputação de Mui et al. (2002a) ..................................................28

2.2.4 Sistemas Histos e Sporas de Zacharia e Maes (2000)....................................................29

2.2.5 Sistema de Reputação Baseado em Papel Social de Carter et al. (2002).........................31

2.2.6 Sistema de Reputação e Endosso de Maximilien e Singh (2002a).....................................33

2.2.7 Sistema de Reputação e Confiança ReGret de Sabater (2003).........................................35

2.2.8 Análise Comparativa dos Modelos e Sistemas de Reputação.............................................37

2.3 REPUTAÇÃo COMO COMPONENTE DA NoÇÃO DE CONFIANÇA ....................................................39

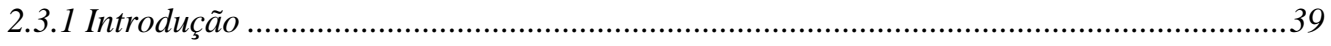

2.3.2 Modelo de Comportamento para Ação Social de Ostrom (1998).....................................40

2.3.3 Modelo Sócio-Cognitivo de Confiança de Castelfranchi et al. (2003a) ............................42

2.4 CONSIDERAÇõES FINAIS......................................................................................................4

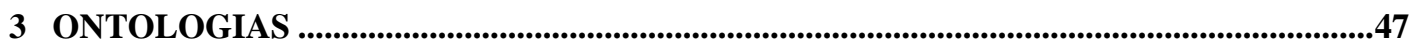

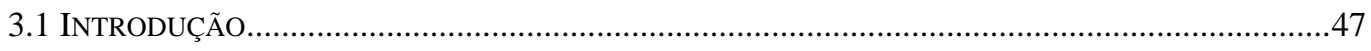

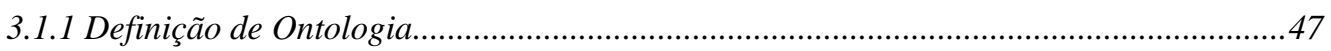

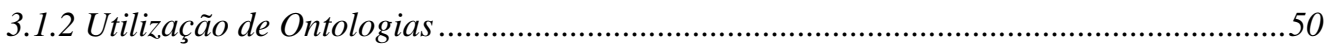

3.2 Metodologias Para A ConStruÇão de OnTOLOGIAS ..........................................................

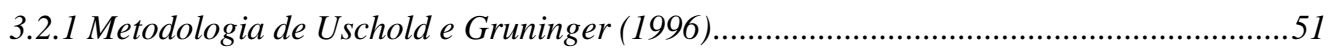

3.2.2 Methontology de Fernandez-Lopez et al. (1997) .............................................................53 
3.3 LiNGUAGENS PARA IMPLEMENTAÇÃO DE ONTOLOGIAS .....................................................54

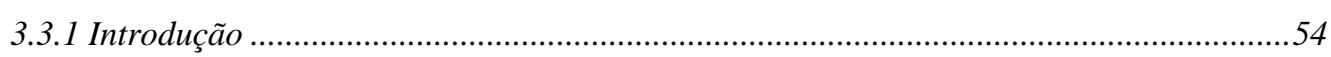

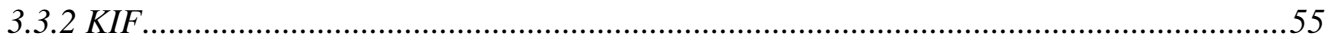

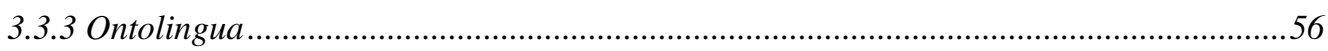

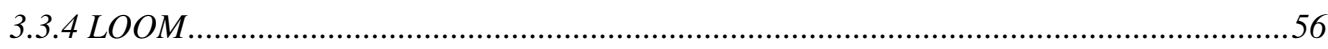

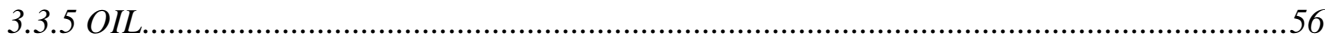

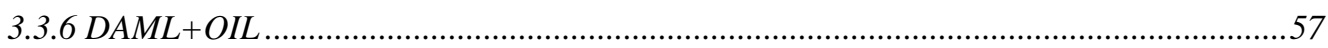

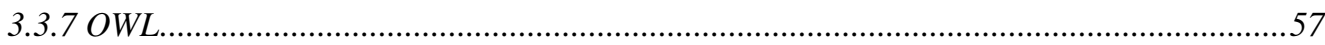

3.4 AMBIENTES PARA A EDIÇÃO E CONSTRUÇÃO DE ONTOLOGIAS .............................................64

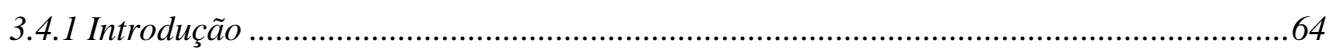

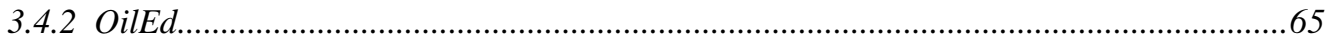

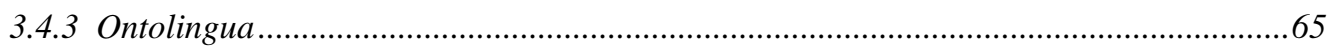

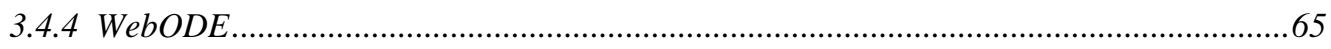

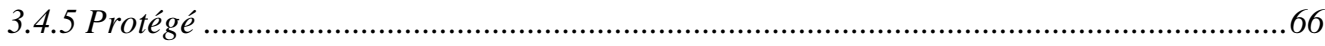

3.5 AMBIENTES PARA RACiOCÍNIO AutOMÁTiCo COM ONTOLOGIAS ..........................................67

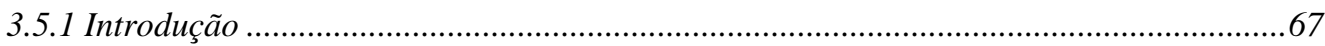

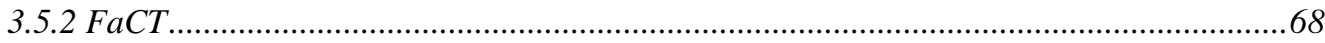

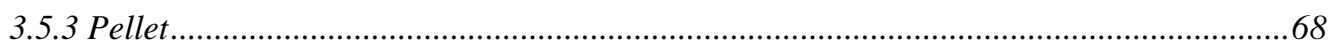

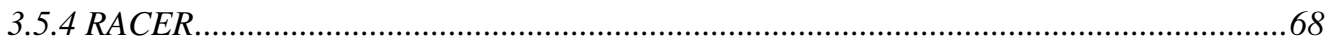

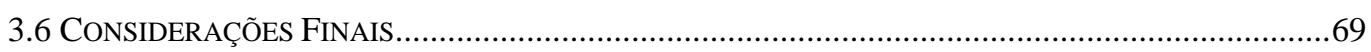

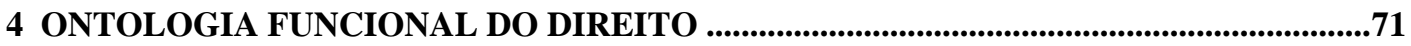

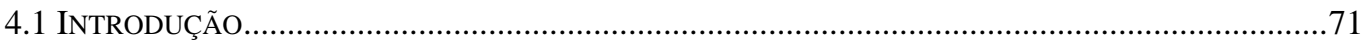

4.2 CATEGORIAS DE CONHECIMENTO DA ONTOLOGIA FunCIONAL DO DiREITO ............................72

4.2.1 Conhecimento de Senso Comum ..............................................................................73

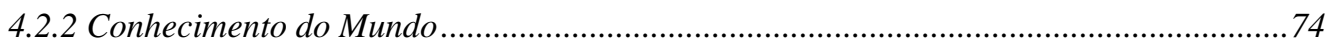

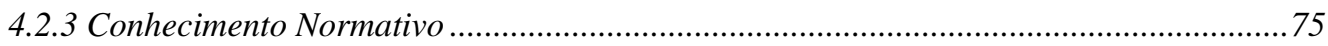

4.2.4 Conhecimento de Responsabilidade .......................................................................77

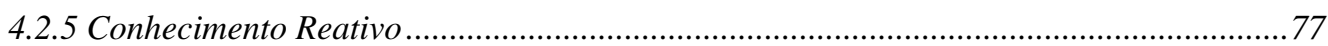

4.3 VisÃo GERAL dA ONTOLOGIA FunCIONAL do DiREITO ..................................................78

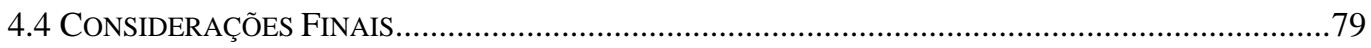

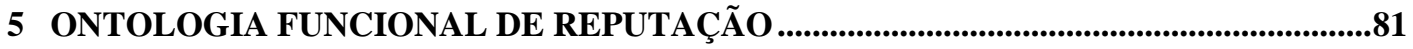

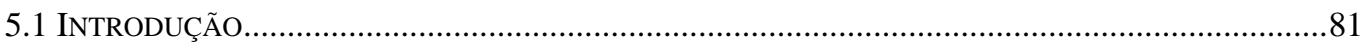

5.2 ESTRATÉGIA DE DESENVOLVIMENTO DA ONTOLOGIA.........................................................83

5.3 OBJETIVO E ESCOPO DA ONTOLOGIA FUnCIONAL DE REPUTAÇÃO ........................................86

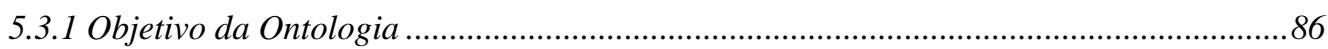

5.3.2 Escopo e Questões de Competência ..............................................................................87

5.4 CATEGORIAS DE CONHECIMENTO DA ONTOLOGIA FunCIONAL DE REPUTAÇÃO .......................89

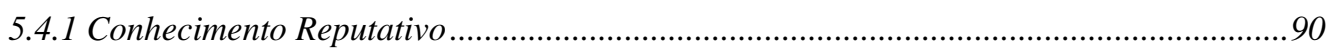

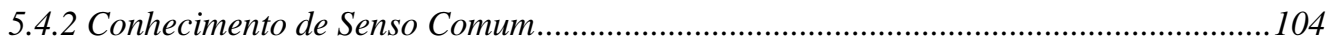




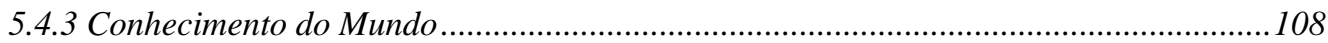

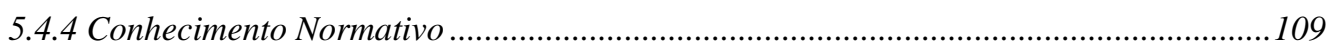

5.4.5 Conhecimento de Responsabilidade .......................................................................112

5.4.6 Relacionamento entre as Categorias da Ontologia Funcional de Reputação................114

5.5 CODIFICAÇÃO DA ONTOLOGIA FUNCIONAL DE REPUTAÇÃO .................................................116

5.5.1 Linguagem e Ferramentas Utilizadas na Codificação ................................................117

5.5.2 Implementação da Ontologia Funcional de Reputação em OWL DL .........................118

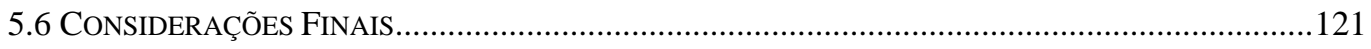

6 AVALIAÇÃO DA ONTOLOGIA FUNCIONAL DE REPUTAÇÃO.......................................123

6.1 Procedimento de AvaliaÇÃo da OnTOLOGIA ..................................................................123

6.2 AvaliaÇÃo UtiLizando o ModElo Cognitivo dE REPUTAÇÃo .......................................126

6.2.1 Questões de Competência ..........................................................................................126

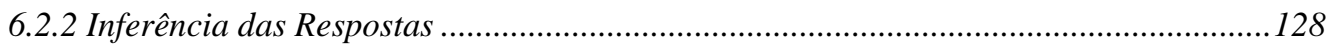

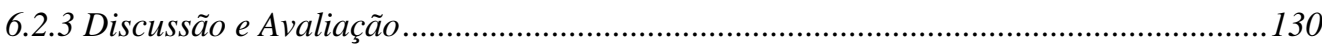

6.3 AvaliaÇÃo Utilizando o Modelo Tipologia de REPUtAÇÃo.......................................131

6.3.1 Questões de Competência ........................................................................................131

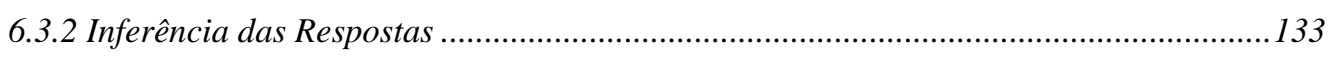

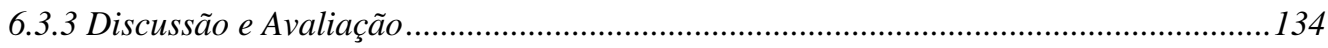

6.4 AvaliaÇÃo UtiLiZANDO OS ModELOS Histos E SPORAS .................................................134

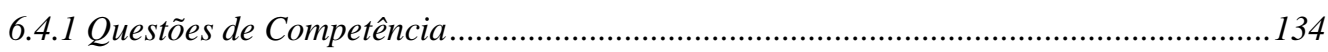

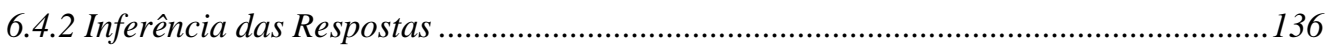

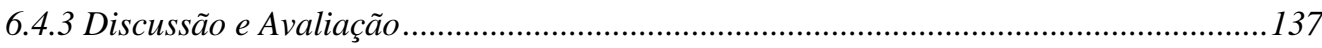

6.5 AVALiAÇÃo UtILIZANDO O SiSTEMA DE REPUTAÇÃo BASEADO EM PAPEL SOCIAL...............137

6.5.1 Questões de Competência .........................................................................................138

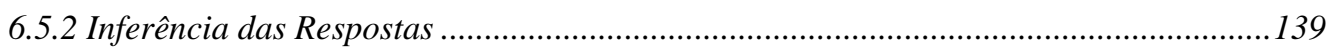

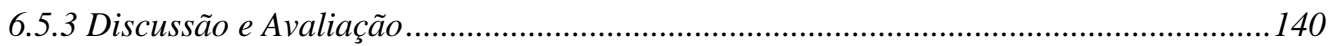

6.6 AvaliaÇÃo UtILIZANDO O Sistema DE REPUTAÇÃO E ENDOSSO.......................................141

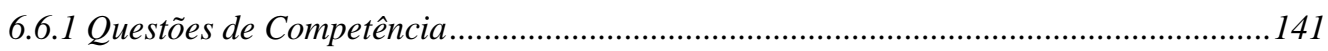

6.6.2 Inferência das Respostas ........................................................................................143

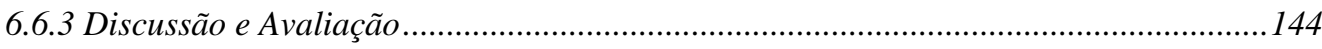

6.7 AVAliaÇÃo UtiLiZANDO o SiSTEMA DE REPUTAÇÃo E CONFIANÇA REGRET .......................145

6.7.1 Questões de Competência ........................................................................................145

6.7.2 Inferência das Respostas ............................................................................................147

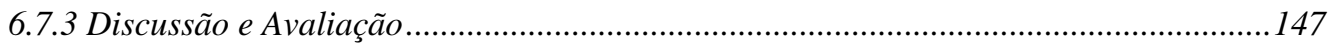

6.8 SUMÁRIO DA AVALIAÇÃO DA ONTOLOGIA.........................................................................149

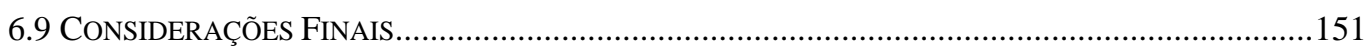

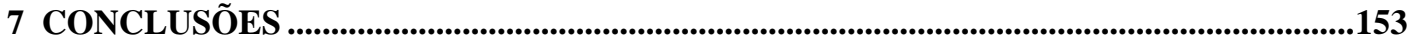

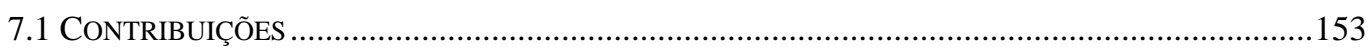

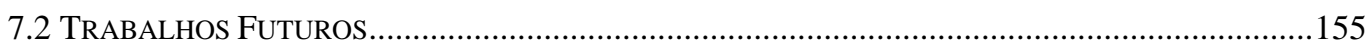




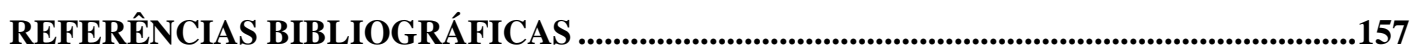

ANEXO A - DESCRIÇÃO DO CONTEÚDO DO CD ............................................................165

ANEXO B - TRADUÇÃO E VERSÃO DE TERMOS...........................................................166 


\section{Lista de Figuras}

FigURA 2.1: FormaÇão DA IMAGEM E DifuSÃO DA REPUTAÇão (CONTE E PAOLUCCI, 2002, P. 72) ........27

FiguRA 2.2: ModELO TIPOLOGIA DE REPUTAÇÃo (MUI ET AL., 2003; P. 127) ................................................29

FiguRA 2.3: COMPONENTES DO MOdelo de REPUtAÇão BASEAdo EM PAPEL (CARTER ET AL., 2002; P.

$520)$ .32

Figura 2.4: Parte do Modelo Conceitual em UML do Sistema de Reputação e Endosso

(MAXIMILIEN E SINGH, 2002B) .35

Figura 2.5: Visão Parcial Do Sistema ReGret (SABATER, 2003, P. 42)

Figura 2.6: REPRESENTAÇÃo dOS RELACIONAMENTOS ENTRE CONFIANÇA, RECIPROCIDADE E REPUTAÇÃO

(MUI ET AL., 2002B) .42

Figura 2.7: MAPA Nebuloso Cognitivo para um Sistema Médico (CASTELFRANCHI ET AL., 2003A) 44

FIGURA 3.1: JANELA DO PROTÉGÉ COM OWL PLUG-IN CONTENDO UMA HIERARQUIA DE CLASSES 67

Figura 4.1: Relacionamento ENTRE O Sistema JuRídico E A Sociedade (VALENTE, 1995, P.49)..........72

Figura 4.2: Hierarquia de CONCEITOS DO CONHECIMENTO DE SENSO COMUM, INSPIRAdo EM ( VALENTE,

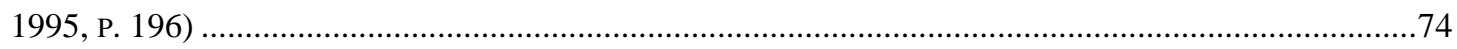

FiguRA 4.3: VISÃo GERAL DA ONTOLOGIA FunCIONAL do DiREITO ( VALENTE, 1995, P. 74) ......................78

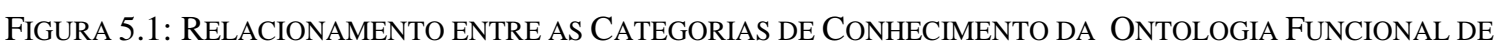

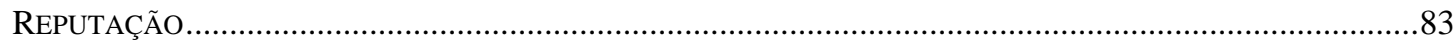

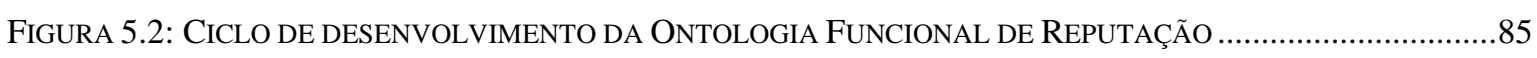

FigURA 5.3: REPRESENTAÇÃO DAS CATEGORIAS DA ONTOLOGIA FUNCIONAL DE REPUTAÇÃO ..........................90

FigURA 5.4: REPRESENTAÇÃO DOS CONCEITOS DA CATEGORIA DE CONHECIMENTO REPUTATIVO .....................91

FigURA 5.5: REPRESENTAÇão do CONCEITO PROPRIEDADE DA REPUTAÇÃ̃O ....................................................94

FIGURA 5.6: REPRESENTAÇÃO DO CONCEITO PAPEL REPUTATIVO ……………………………………….......96

FIGURA 5.7: REPRESENTAÇÃO DO CONCEITO COMPONENTE DE CÁLCULO DA REPUTAÇÃO ...............................101

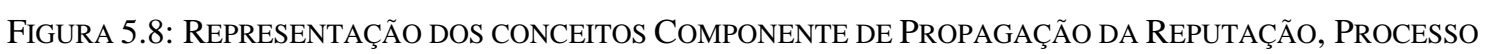

REPUTATIVO E COMPONENTE DE CÁLCULO DA REPUTAÇÃO ....................................................................102

FIGURA 5.9: REPRESENTAÇÃO DOS CONCEITOS DA CATEGORIA CONHECIMENTO REPUTATIVO ........................104

FiguRA 5.10: REPRESENTAÇÃo dos CONCEITOS DA CATEGORIA CONHECIMENTO DE SENSO COMUM .............107

FIGURA 5.11: REPRESENTAÇÃO DOS CONCEITOS DA CATEGORIA CONHECIMENTO DO MUNDO........................109

FIGURA 5.12: REPRESENTAÇÃO DOS CONCEITOS DA CATEGORIA CONHECIMENTO NORMATIVO.........................111

FigurA 5.13: REPRESENTAÇÃO DOS CONCEITOS DA CATEGORIA CONHECIMENTO DE RESPONSABILIDADE ...114

FiguRA 5.14: PRINCIPAIS CONCEITOS E RELACIONAMENTOS DA ONTOLOGIA FunCIONAL DE REPUTAÇÃO .....115

Figura 5.15: TELA DO PROTÉGÉ APRESENTANDO UMA PARTE DAS CLASSES DA ONTOLOGIA FUNCIONAL DE

REPUTAÇÃO 120

FiguRA 6.1: REPRESENTAÇÃO DAS CLASSES USADAS NA AVALIAÇÃO DA ONTOLOGIA FUNCIONAL DE REPUTAÇÃO 
FiguRA 6.2: DiAgRAMA DAS CLASSES QUE REPRESENTAM OS CONCEITOS DO MODELO COGNITIVO DE REPUTAÇÃO 126

FIGURA 6.3: REPRESENTAÇÃO DO PROCEDIMENTO DE SUBSUNÇÃO DA ONTOLOGIA E DE SEU RESULTADO .....129

Figura 6.4: DiAgRAMA DA HIERARQUIA INFERIDA PARA AS CLASSES DO MODELO COGNITIVO DE REPUTAÇÃO, REALÇADAS PELA LINHA PONTILHADA, MOSTRANDO AS SUPERCLASSES A ELAS ASSOCIADAS PELO PROCESSO DE SUBSUNÇÃO . 130

FiguRA 6.5: DiAgRAMA DAS CLASSES QUE REPRESENTAM OS CONCEITOS DO MODELO TIPOLOGIA DE REPUTAÇÃO

Figura 6.6: DiAgRAMA DA HIERARQUiA INFERIDA PARA AS CLASSES DO MODELO TIPOLOGIA DE REPUTAÇÃO, REPRESENTADAS ENTRE AS LINHAS PONTILHADAS, MOSTRANDO AS SUPERCLASSES A ELAS ASSOCIADAS PELO PROCESSO DE SUBSUNÇÃO

FigURA 6.7: DIAGRAMA DAS CLASSES QUE REPRESENTAM OS CONCEITOS DOS SISTEMAS HISTOS E SPORAS .135

FIGURA 6.8: DIAGRAMA DA HIERARQUIA INFERIDA PARA AS CLASSES DOS SISTEMAS HISTOS E SPORAS (REALÇADAS PELA LINHA PONTILHADA), MOSTRANDO AS SUPERCLASSES A ELAS ASSOCIADAS PELO PROCESSO DE SUBSUNÇÃO

FiguRA 6.9: DiAGRAMA DAS CLASSES QUE REPRESENTAM OS CONCEITOS DO SiSTEMA DE REPUTAÇÃO BASEADO EM PAPEL SOCIAL

FIGURA 6.10: DiAGRAMA DA HIERARQUIA INFERIDA PARA AS CLASSES DOS SISTEMAS DE REPUTAÇÃO BASEADO EM PAPEL SOCIAL (REALÇADAS PELA LINHA PONTILHADA), MOSTRANDO AS SUPERCLASSES A ELAS ASSOCIADAS PELO PROCESSO DE SUBSUNÇÃO 140

FIGURA 6.11: DIAGRAMA DAS CLASSES QUE REPRESENTAM OS CONCEITOS DO SISTEMA DE REPUTAÇÃO E ENDOSSO

FIGURA 6.12: DiAGRAMA DA HIERARQUIA INFERIDA PARA AS CLASSES DOS SISTEMAS DE REPUTAÇÃO E ENDOSSO (REALÇADAS PELA LINHA PONTILHADA), MOSTRANDO AS SUPERCLASSES A ELAS ASSOCIADAS PELO PROCESSO DE SUBSUNÇÃO

FIGURA 6.13: DIAGRAMA DAS CLASSES QUE REPRESENTAM OS CONCEITOS DO SISTEMA REGRET .146

FIGURA 6.14: DIAGRAMA DA HIERARQUIA INFERIDA PARA AS CLASSES DOS SISTEMAS REGRET (REALÇADAS PELA LINHA PONTILHADA), MOSTRANDO AS SUPERCLASSES A ELAS ASSOCIADAS PELO PROCESSO DE SUBSUNÇÃO 


\section{Lista de Tabelas}

TABELA 2.1: COMPARAÇÃO DOS MODELOS E SISTEMAS DE REPUTAÇÃO …………………………………......38

TABELA 4.1: NORMAS PRIMÁRIAS, COMPORTAMENTOS E STATUS NORMATIVOS (VALENTE, 1995, P. 95) .....76

TABELA 5.1: QUESTÕES DE COMPETÊNCIA SEGUNDO OS CRITÉRIOS DE ANÁLISE DA REPUTAÇÃO .......................88

TABELA 5.2: ReLACiONAMENTOS DE NATUREZA DA REPUTAÇÃO E TiPo dE REPUTAÇÃO ..................................95

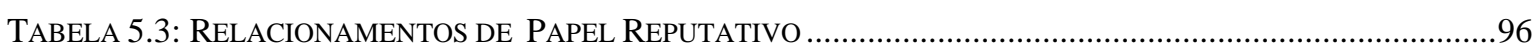

TABELA 5.4: Relacionamentos De PRocesso RePutativo ......................................................................102

TABELA 5.5: RELACIONAMENTOS DE CONHECIMENTO DE SENSO COMUM ……..................................................107

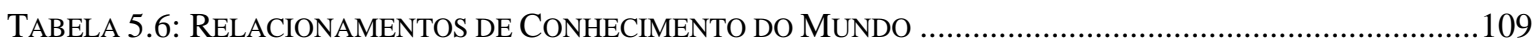

TABELA 5.7: RELACIONAMENTOS DE CONHECIMENTO NORMATIVO..............................................................111

TABELA 5.8: RELACIONAMENTOS DE CONHECIMENTO DE RESPONSABILIDADE ...............................................114

TABELA 6.1: QUESTÕES DE COMPETÊNCIA E RESPECTIVAS CLASSES OWL DL PARA CONCEITOS DO MODELO COGNITIVO dE REPUTAÇÃO 127

TABELA 6.2: QUESTÕES DE COMPETÊNCIA E RESPECTIVAS ClASSES OWL DL PARA CONCEITOS DO MODELO

Tipologia de REPUTAÇÃo 132

TABELA 6.3: QUESTÕES DE COMPETÊNCIA E RESPECTIVAS CLASSES OWL DL PARA CONCEITOS DOS SISTEMAS HISTOS E SPORAS 135

TABELA 6.4: QUESTÕES DE COMPETÊNCIA E RESPECTIVAS CLASSES OWL DL PARA CONCEITOS DO SISTEMA DE REPUTAÇ̃̃O BASEADO EM PAPEL SOCIAL 138

TABELA 6.5: QUESTÕES DE COMPETÊNCIA E RESPECTIVAS CLASSES OWL DL PARA CONCEITOS DO SISTEMA DE REPUTAÇÃO E ENDOSSO .142

TABELA 6.6: QUESTÕES DE COMPETÊNCIA E RESPECTIVAS CLASSES OWL DL PARA CONCEITOS DO SISTEMA REGRET 146

TABELA 6.7: SUMÁRIO DAS RESPOSTAS ÀS QUESTÕES DE COMPETÊNCIA SEGUNDO OS MODELOS E SISTEMAS DE REPUTAÇÃO POR CRITÉRIOS DE ANÁLISE. .149

TABELA 7.1: EXEMPLO DA COMPARAÇÃO ENTRE TERMOS UTILIZADOS PELOS MODELOS DE REPUTAÇÃO ........155

TABELA 8.1: TRADUÇÃO DOS NOMES DAS CLASSES DA ONTOLOGIA FUNCIONAL DE REPUTAÇÃO.....................166

TABELA 8.2: VERSÃO DOS NOMES DAS CLASSES DA ONTOLOGIA FUNCIONAL DE REPUTAÇÃO...........................168

TABELA 8.3: NOMES DAS PROPRIEDADES DA ONTOLOGIA FUNCIONAL DE REPUTAÇÃO ...................................170 


\section{Introdução}

A área de Sistemas Multiagentes (SMA), sub-área da Inteligência Artificial (IA) que estuda a coletividade ao invés do indivíduo, empresta as noções de sociedade e de comportamento social de outras áreas, como a Sociologia e a Psicologia.

Muitos mecanismos foram propostos para regular as relações sociais entre agentes em SMA, entre eles as emoções (BAZZAN et al., 1999), as relações de dependência existentes entre os agentes (SICHMAN, 1995) e as normas sociais (CASTELFRANCHI et al., 1998a). Normas jurídicas e normas sociais têm sido objetos de estudo de algumas áreas da IA, como sistemas especialistas jurídicos (VALENTE, 1995) e agentes autônomos normativos (CONTE et al., 1999).

Em sociedades onde o altruísmo é limitado, as normas de conduta permitem prever o comportamento futuro dos outros, e esta previsibilidade é necessária para a manutenção da cooperação entre os indivíduos (HART, 1961). O caráter normativo do comportamento social de agentes é atualmente uma das áreas de interesse dos SMA's. Como nas sociedades humanas, um agente com comportamento regrado por normas de conduta traz vários benefícios para o convívio social, tais como a previsibilidade do comportamento de outrem e a resolução de conflitos. Castelfranchi et al. (1998a) sugerem que a boa reputação é um tipo de recompensa social pela conduta conforme a norma, enquanto a má reputação é um tipo de punição pela conduta contrária à norma.

O termo reputação é definido pelo dicionário Aurélio (FERREIRA, 1986) como sendo "o ato ou efeito de considerar, julgar, dar bom crédito a, avaliar, estimar e calcular”. Considera ainda a reputação como "similar à fama, à celebridade ou ao renome”.

A reputação tem sido objeto de estudo de diversas áreas de pesquisa, tais como as Ciências Humanas e a Inteligência Artificial $^{1}$. Conte e Paolucci (2002) ressaltam que, apesar da noção de reputação ser um artefato antigo, não se trata de modo algum de uma relíquia, visto que até as sociedades eletrônicas precisam das noções de confiança e credibilidade a fim de fortalecer o comprometimento e a responsabilidade entre os parceiros.

\footnotetext{
${ }^{1}$ (BAUMEINSTER, 1982; ALT et al.,, 1988; BROMLEY, 1993; CONTE e PAOLUCCI, 2002; FERRIS et al., 2003; SABATER, 2003) entre outros.
} 
Uma visão integrada da noção de reputação entre as diversas áreas das Ciências Humanas foi proposta por Shenkar e Yuchtman-Yaar (1997) e sugere que o conceito que os economistas nomeiam reputação é o mesmo que os estudiosos da área de Marketing chamam de imagem, os sociólogos, de prestígio, e os especialistas em Direito, de boa-fé (goodwill). Entretanto, não há uma definição comum desse conceito dado que os estudos realizados se encontram em diversos níveis de análise e empregam definições diferentes do mesmo termo (FERRIS et al., 2003).

Na Psicologia, Bromley (1993) desenvolveu um importante trabalho sobre reputação, no qual apresenta os diversos aspectos que determinam a reputação de um indivíduo, salientando que envolvem fatores complexos e interdependentes, e não totalmente sob o controle do indivíduo. Em IA, vários modelos e mecanismos computacionais foram propostos ${ }^{2}$, oferecendo distintas formas de representar a reputação e os aspectos envolvidos.

\subsection{Motivação}

Nos ambientes de comércio eletrônico, bem como nos de comércio tradicional, os agentes buscam os seus próprios interesses e estão sujeitos à competição e trapaças. Para o bom funcionamento desses ambientes, a confiança nos parceiros e nas regras e procedimentos vigentes são fundamentais (CASTELFRANCHI et al., 2000a). Assim, os mecanismos computacionais de reputação e confiança desempenham atualmente um papel decisivo nos mercados eletrônicos, nas sociedades eletrônicas e nos Sistemas Multiagentes, contribuindo para o fortalecimento de uma forma distribuída de controle info-social (SABATER, 2003).

Entretanto, como nas sociedades humanas, no mundo dos agentes existem diversos modelos e sistemas de reputação, que usam distintas noções deste conceito. Essa diversidade, que por um lado mostra a vitalidade e a ampla produção desta área de pesquisa, por outro lado dificulta a interoperabilidade em sistemas multiagentes envolvendo agentes construídos a partir de diferentes modelos de reputação. A análise de tais modelos mostra que, em alguns casos, significados diferentes são associados a termos similares e, em outros casos, o mesmo significado é representado por termos distintos. Assim, os termos “confiança direta” (SABATER, 2003) e “confiança”

\footnotetext{
2 (ZACHARIA e MAES, 2000; CONTE e PAOLUCCI, 2002; MUI et al., 2002a; SABATER, 2003) entre outros.
} 
(CASTELFRANCHI et al., 2003a) são exemplos do primeiro caso, enquanto "reputação direta” (SABATER, 2003) e “imagem” (CONTE e PAOLUCCI, 2002) são exemplos do segundo.

Portanto, a construção de um sistema multiagentes envolvendo agentes que trocam informações sobre reputação, mas baseados em distintos modelos, requer a utilização de uma camada de integração semântica (VISSER et al., 2000), capaz de atuar como uma interlingua entre tais agentes, possibilitando a identificação de similaridades e de diferenças entre os diversos modelos de reputação.

\subsection{Objetivo}

A análise de diversos modelos computacionais de reputação mostra que a noção de reputação é muitas vezes representada de forma intuitiva, sem uma definição precisa e sem a utilização de bases teóricas ou empíricas mais elaboradas.

Em muitos casos, esses modelos computacionais não possuem uma base ontológica clara que permita entender porque e como eles funcionam. Em sua revisão de modelos computacionais de reputação e confiança, Sabater e Sierra (2005) constatam a ausência de uma estrutura que permita avaliar e comparar os modelos computacionais de reputação e confiança por meio de condições representativas e comuns a esses modelos.

O presente trabalho propõe uma Ontologia Funcional de Reputação para agentes. Esta ontologia tem como objetivo oferecer uma perspectiva funcional para a representação e análise da reputação como mecanismo de controle social em sociedades de agentes, de forma a sustentar a implementação de sistemas de reputação. A perspectiva funcional adotada consiste em agrupar os conceitos que compõem a ontologia em categorias, de acordo com a sua função no mecanismo de controle social.

Em linhas gerais, os objetivos desta ontologia podem ser descritos da seguinte forma:

1. Representar o conhecimento sobre reputação - apresentando uma parte do conhecimento científico sobre reputação por meio de categorias e conceitos, agrupados segundo uma perspectiva funcional;

2. Ilustrar o uso da reputação para controle social - mostrando como a reputação pode ser usada como parte de um mecanismo de controle social baseado em normas sociais. Cabe ressaltar que o objetivo deste trabalho é fornecer subsídios para a construção de um modelo de agentes que use a 
reputação como mecanismo de controle, através da ilustração de um possível arcabouço, e não construir tal modelo;

3. Funcionar como uma interlingua - mitigando a ausência de padrão entre os diversos modelos computacionais existentes, provendo uma conceitualização que pode ser usada como uma interlingua na comparação dos diversos modelos e sistemas de reputação.

\subsection{Metodologia}

Os objetivos descritos na seção anterior foram alcançados através da realização de três etapas. A primeira etapa consistiu na coleta dos conceitos que formam o núcleo da ontologia. Estes conceitos representam de forma estruturada os aspectos envolvidos na noção de reputação identificados tanto em Ciências Humanas (FERRIS et al., 2003; BROMLEY, 1993) quanto nos trabalhos em IA, especialmente em SMA (CONTE e PAOLUCCI, 2002; YU e SINGH, 2002; MUI et al., 2002a, 2003; SABATER, 2003 entre outros).

Na segunda etapa, esse núcleo foi inserido em uma estrutura mais ampla, as categorias de conhecimento propostas pela Ontologia Funcional do Direito (VALENTE, 1995). A justificativa da utilização desta ontologia na construção da ontologia de reputação aqui proposta é a similaridade existente entre uma norma social e uma norma jurídica (HART, 1961). Enquanto no mundo jurídico a violação à norma jurídica gera uma punição legal do agente, no mundo social a má reputação é a penalidade associada ao comportamento que viola a norma social (CASTELFRANCHI et al., 1998a). A categorização de conceitos definida para o mundo jurídico foi utilizada para a representação do mundo social, por meio (i) da extensão do conceito de norma jurídica em norma social, (ii) da substituição da reação jurídica (sanção ou compensação) pela reação social (má reputação ou boa reputação), e (iii) da interiorização do mecanismo de controle social, que passa a existir na 'mente' do agente e não mais como instituição jurídica externa a ele. De forma análoga à Ontologia Funcional do Direito, a distinção entre as categorias da Ontologia Funcional de Reputação é realizada de acordo com uma perspectiva funcional, segundo a qual cada componente do sistema reputativo existe para cumprir uma função específica no esforço para atingir objetivos sociais mais amplos, como a confiança, a reciprocidade e a cooperação social. 
A terceira etapa consistiu na codificação das categorias e conceitos que compõem a ontologia em uma linguagem formal baseada em lógica descritiva, a Ontology Web Language (OWL) (DEAN e SCHREIBER, 2004). Uma vez a ontologia formalmente implementada, os termos utilizados por diversos modelos e sistemas de reputação foram descritos por meio de seus conceitos. A utilização de um motor de inferência permitiu comparar os conceitos utilizados por estes modelos e sistemas com os conceitos da ontologia, que atuou como uma interlingua.

\subsection{Organização do Texto}

Além deste capítulo introdutório, este texto é composto por seis outros capítulos. O capítulo 2 apresenta a noção de reputação segundo os estudos realizados no campo das Ciências Humanas, e a forma como essa noção foi representada por diversos modelos e sistemas de reputação.

O capítulo 3 procura responder às seguintes questões: “O que são ontologias?”, “Para que servem as ontologias?” e “Como desenvolver ontologias?”, dentro da linha de pesquisa deste trabalho, a IA. Para tanto, apresenta um panorama dos elementos que fazem parte da construção de ontologias, quais sejam, metodologias, linguagens, ambientes de desenvolvimento e motores de inferência.

O capítulo 4 apresenta a Ontologia Funcional do Direito, proposta por Valente (1995), que, como já apresentado na seção anterior, fornece um arcabouço básico para este trabalho.

A Ontologia Funcional de Reputação ${ }^{3}$, objeto deste trabalho, é apresentada no capítulo 5, que descreve a estratégia de desenvolvimento adotada para a sua construção, as categorias e conceitos que a compõem, e as características da sua implementação, realizada em OWL DL.

O capítulo 6 apresenta o procedimento utilizado para a avaliação da Ontologia Funcional de Reputação, bem como a discussão dos resultados obtidos nesta avaliação.

Finalmente, o capítulo 7 apresenta as contribuições deste trabalho e um esboço dos trabalhos futuros.

\footnotetext{
${ }^{3}$ Por abuso de linguagem, o artigo definido “a” é utilizado no lugar do artigo indefinido "uma” para qualificar a Ontologia Funcional de Reputação ao longo deste texto.
} 


\section{Reputação: Noções, Modelos e Sistemas}

O objetivo deste capítulo é apresentar a noção de reputação segundo os estudos realizados no campo das Ciências Humanas e da IA.

O capítulo está organizado em quatro seções. Inicialmente, é apresentada na seção 2.1 a noção de reputação em sociedades humanas. Em seguida, a seção 2.2 apresenta alguns modelos e sistemas de reputação desenvolvidos no campo da IA, bem como uma análise comparativa dos mesmos. A seção 2.3 apresenta duas formas de utilizar a noção de reputação como componente da noção de confiança (trust). Finalmente, a seção 2.4 apresenta algumas considerações sobre os modelos e sistemas de reputação estudados e sobre a dificuldade encontrada, tanto em Ciências Humanas como em IA, na identificação e representação dos aspectos envolvidos na noção de reputação.

\subsection{Noção de Reputação}

Englobando áreas como a Psicologia, a Sociologia, a Economia, o Marketing e a Teoria das Organizações, Ferris et al. (2003) realizaram uma completa e recente revisão bibliográfica sobre a reputação, na qual é destacada a relevância da obra de Bromley (1993). Essa obra, realizada no campo da Psicologia, apresenta uma ampla discussão sobre a noção de reputação, baseada em resultados de pesquisas empíricas com grupos humanos, e fornece um quadro conceitual que pôde ser usado no desenvolvimento da Ontologia Funcional de Reputação proposta neste trabalho.

Segundo Bromley (1993), reputações são sistemas coletivos de crenças e opiniões que influenciam as ações das pessoas com respeito às demais pessoas e às coisas. No plano individual, a reputação pode ser definida como sendo o núcleo de impressões compartilhadas e expressadas pela maioria dos membros de uma rede social. Pode ainda ser considerada como um mecanismo social utilizado para reduzir a incerteza frente à impossibilidade de se conhecer previamente todos os atributos importantes na interação dos indivíduos, tais como a qualidade e o desempenho desses indivíduos. 


\subsubsection{Reputação como Objeto da Psicologia}

A reputação está fortemente associada a diversos aspectos da Psicologia Social, tais como relacionamentos interpessoais, atitudes, estereótipos, preconceitos, personalidade, comportamento desviante e cognição social (BROMLEY, 1993, p.30). Segundo Bromley (1993, p. 32), a psicologia da vida social humana inclui três áreas de interesse, nomeadamente, a personalidade, o relacionamento entre pessoas e entre grupos, e a reputação. A personalidade é o conjunto de características pessoais que dão consistência e regularidade ao comportamento de um indivíduo. Ao mesmo tempo em que existe uma diferença clara entre a personalidade e a reputação, existe também uma forte conexão entre esses conceitos. Por um lado, a reação das outras pessoas às ações do indivíduo estabelece uma relação entre a identidade pessoal (auto-imagem) e identidade social (reputação). Por outro lado, grande parte do comportamento social de uma pessoa é governada pela consideração da sua própria reputação (BROMLEY, 1993, p. 51).

A partir de pesquisas realizadas em diversos campos e disciplinas de pesquisa, Ferris et al. (2003) propõem uma definição de trabalho (working definition) para a reputação pessoal, segundo a qual a reputação é uma identidade perceptiva que reflete a combinação complexa das características e realizações pessoais, dos comportamentos demonstrados e das imagens almejadas. Essa combinação ocorre durante um certo período de tempo, sendo que os fatores que a compõem podem ser observados diretamente e/ou reportados por fontes secundárias (FERRIS et al., 2003, p. 215). Os autores salientam diversos pontos que resultam dessa definição, tais como (i) cada indivíduo pode ter diversas reputações, que eventualmente podem ser conflitantes entre si, (ii) cada reputação tem um caráter perceptivo e subjetivo por natureza, tratando-se mais de uma realidade socialmente construída do que de uma realidade objetiva, (iii) a reputação é influenciada pelas características dos indivíduos, como gênero, etnia, idade, assim como pelas suas realizações, experiências adquiridas e educação formal, (iv) a reputação tem uma dimensão temporal, visto que não emerge instantaneamente. Salientam ainda que (v) no processo de criação da reputação interagem diversos aspectos do comportamento do indivíduo e das decisões por ele tomadas (FERRIS et al., 2003, p. 216-217).

\subsubsection{Formação da Reputação}

A reputação pessoal é construída dentro de uma cultura específica e tem relações fortes com os valores vigentes em determinadas comunidades. As normas, tanto morais 
como legais, que regem uma sociedade, afetam a forma de julgamento e avaliação do comportamento dos indivíduos. Assim, a reputação é formada dentro de um contexto específico, que inclui o conjunto de papéis do individuo, as normas sociais e o ambiente (FERRIS et al., 2003). As questões sobre os relacionamentos entre esses fatores e as formas pelas quais eles afetam a formação da reputação são subjetivas e complexas, pois dependem da percepção que as pessoas têm de uma dada situação. A maneira pela qual o papel é entendido como tal e não como característica inerente da pessoa altera a avaliação da situação e em conseqüência a avaliação da reputação pessoal. Pode-se avaliar um dado comportamento como tendo uma causa externa, por exemplo o papel desempenhado pelo indivíduo, ou como tendo uma causa interna, por exemplo a motivação do indivíduo.

Cada indivíduo possui diversas reputações, associadas aos diversos grupos aos quais pertence. Além disso, uma reputação pode ser primária, quando resulta do contato direto com o indivíduo observado, ou pode ser secundária, quando resulta do relato de terceiros. Entretanto, é possível extrair uma reputação consistente dessas diversas reputações. A questão que se coloca é quais são os princípios que regulam esse processo de síntese de diversas reputações (BROMLEY, 1993; FERRIS et al., 2003).

\subsubsection{Reputação, Auto-Imagem, Auto-Estima e Comportamento}

Pode-se esperar algumas discrepâncias entre a auto-imagem e a reputação de um indivíduo (BROMLEY, 1993). A imagem que um individuo tem de si mesmo está associada à sua auto-estima, ou à falta dessa, enquanto a reputação vincula-se às atitudes, relacionamentos interpessoais, estereótipos e preconceitos vigentes em uma sociedade. A discrepância entre a imagem e a reputação pode surgir quando algumas características individuais são avaliadas como positivas ou negativas pelo próprio indivíduo, e essa avaliação não coincide com a avaliação feita pelas pessoas que com ele interagem. Para ilustrar essa idéia, Bromley (1993, p. 101) cita um provérbio inglês segundo o qual "muitos homens podem não reconhecer a própria reputação se cruzarem com ela na rua”.

A auto-estima afeta a reputação de forma indireta, visto que influencia o desempenho do indivíduo, e esse desempenho após algum tempo afeta a sua reputação. De forma similar, a reputação, mesmo quando não merecida, afeta a auto-estima do indivíduo e, portanto, tem impacto sobre o seu desempenho. Nesse caso, um declínio da reputação do indivíduo pode ter efeito positivo sobre o seu desempenho, visto que pode estimulá-lo a melhorá-lo para restabelecer a sua reputação. Contudo, a preocupação excessiva com a própria reputação pode inibir as ações do indivíduo, pois ele evita uma eventual alteração 
de comportamento devido ao receio de provocar uma má impressão entre os membros da sua comunidade (BROMLEY, 1993, p.81).

A reputação reflete com maior intensidade as características que distinguem os indivíduos, e nem tanto aquelas que eles têm em comum. Segundo diversos autores (BROMLEY, 1993; HASTORF et al.,1973; FERRIS et al., 2003), o comportamento normal e esperado não requer explicações, ele é auto-explicativo pois está de acordo com a norma social. Entretanto, o comportamento desviante ou inesperado chama a atenção e requer explicações, revelando mais sobre o indivíduo do que o comportamento normal. $\mathrm{O}$ comportamento desviante é um dos aspectos envolvidos com a reputação, mas nem sempre produz efeitos na avaliação da reputação de um indivíduo. Bromley (1993) cita dois motivos pelos quais esse comportamento não afeta necessariamente a avaliação. O primeiro deles é que o comportamento desviante pode ser escondido pelo indivíduo e não detectado pelas demais pessoas. O segundo motivo é que o indivíduo tem múltiplas reputações correspondentes aos diversos grupos aos quais pertence e esses grupos podem não ter conexão entre si. Assim, mesmo que o comportamento desviante seja detectado pelos membros de um grupo e afete a reputação do indivíduo naquele grupo, essa informação não será transmitida para os demais grupos e, portanto, as outras reputações do indivíduo não serão alteradas pelo comportamento desviante.

\subsubsection{Rede Social e Rede de Reputação}

A análise das redes sociais é relevante para o estudo da reputação na medida em que oferece uma abordagem sistemática e quantitativa para a avaliação da disseminação das informações e das influências entre os membros de um grupo social. A principal questão que se coloca sobre as redes sociais é quem são as pessoas que o indivíduo conhece, enquanto nas redes de reputação a questão é por quais pessoas esse indivíduo é conhecido e o que pensam dele. Os atributos que são incorporados a uma reputação dependem dos interesses e valores dos membros de uma rede social. A percepção, a seleção, a atenção e mesmo a lembrança dos diversos atributos depende das características da rede social. Bromley (1993) ressalta que alguns grupos sociais têm mais peso na atribuição da reputação de um indivíduo que os demais e, portanto, no estudo das redes de reputação a ênfase deve estar na distribuição da informação dentro desses grupos.

O conceito de reputação pessoal e as suas implicações nas relações sociais são temas ao mesmo tempo fascinantes e de difícil compreensão. Bromley (1993) salienta que a pesquisa científica sobre reputação depende de definições operacionais, tais como (i) a 
definição das fronteiras dos grupos sociais, (ii) a especificação dos critérios de medição dos atributos da reputação a serem investigados, (iii) e, finalmente, uma definição do conceito de reputação. Considerando-se que a reputação é essencialmente um sistema coletivo de crenças subjetivas entre os membros de um grupo social, o problema consiste em como avaliar esse sistema de forma científica e útil. Essa avaliação deve considerar que as reputações têm um ciclo de vida, visto que elas se formam, se desenvolvem, se alteram e, eventualmente, deixam de existir.

\subsection{Modelos e Sistemas de Reputação}

\subsubsection{Introdução}

Segundo Resnick et al. (2000), um sistema de reputação é responsável por coletar, distribuir e agregar as informações sobre o comportamento passado de seus participantes, de maneira a ajudá-los a decidir em quem confiar, encorajando comportamentos leais e dissuadindo comportamentos desonestos. Esses sistemas procuram estabelecer vestígios das transações atuais no futuro, criando a expectativa de que outras pessoas irão em busca desses vestígios antes de se decidirem a realizar ou não uma determinada transação. Para que esses sistemas tenham um bom funcionamento, são necessárias três propriedades: (i) os atores devem permanecer no sistema por um período longo o suficiente para possibilitar as interações futuras, (ii) as informações sobre as interações devem ser coletadas e distribuídas de forma a serem acessados no futuro e (iii) essas informações devem ser usadas em situações de tomada de decisão.

O objetivo desta seção é apresentar e analisar alguns modelos conceituais e sistemas de reputação que fazem parte da literatura de IA. Esses modelos consistem em uma representação do conhecimento na forma de conceitos, descritos apenas em linguagem natural ou organizados em diagramas hierárquicos, enquanto os sistemas são artefatos de software.

Os modelos conceituais de reputação apresentados são o Modelo Cognitivo de Reputação proposto por Conte e Paolucci (2002) e a Tipologia de Reputação proposta por Mui et al. (2002a, 2003). Os sistemas de reputação apresentados são: Sistemas Histos e Sporas, propostos por Zacharia e Maes (2000); Sistema de Reputação baseada em papéis sociais, proposto por Carter et al. (2002); Sistema de Reputação e Endosso, desenvolvido por Maximilien e Singh (2002a, 2002b); o Sistema de Reputação e Confiança ReGret, desenvolvido por Sabater (2003). 
Estes modelos e sistemas de reputação foram selecionados entre diversos outros ${ }^{4}$. Esta escolha deveu-se à originalidade da solução proposta e à sua importância para o desenvolvimento da Ontologia Funcional de Reputação, na medida em que oferecem opções para a representação dos diversos aspectos associados à noção de reputação. Maiores detalhes sobre a razão da escolha destes modelos e sistemas encontram-se descritos na seção 2.4 .

\subsubsection{Modelo Cognitivo de Reputação de Conte e Paolucci (2002)}

O Modelo Cognitivo de Reputação proposto por Conte e Paolucci (2002) está baseado na noção de estado mental de um agente, tal como crença, meta-crença e objetivo. Este modelo envolve dois conceitos centrais, a imagem (image) e a reputação (reputation) de um agente, e especifica quais são os fatores envolvidos na sua propagação.

A imagem é uma propriedade subjetiva do agente. Tal propriedade representa a avaliação que um agente avaliador faz de um agente alvo e consiste no conjunto de crenças do avaliador sobre as características deste agente. Essas características refletem a disposição do agente alvo em agir segundo as normas e costumes sociais vigentes. A formação da imagem, pelo avaliador, depende da informação adquirida através de sua experiência.

A reputação corresponde ao processo e ao efeito da transmissão da imagem de um agente alvo na esfera social. É, portanto, uma propriedade social objetiva que emerge da propagação de uma representação cognitiva, a imagem do agente alvo (CONTE e PAOLUCCI, 2000, p. 72). A reputação pode ser herdada do grupo social ao qual o agente pertence. Por exemplo, um funcionário pode herdar a reputação da firma onde trabalha. A reputação pode, ainda, ser estendida de um agente a um outro, desde que exista entre eles relacionamento de proximidade ou de similaridade, o que corresponde ao preconceito (prejudice) (CONTE e PAOLUCCI, 2000, p. 76-77).

Enquanto a imagem corresponde a uma crença do agente, a reputação é uma metacrença, visto que é uma crença sobre a avaliação de um agente alvo feita por outros agentes avaliadores. Os autores salientam que, apesar de imagem e reputação serem noções conceitualmente distintas, empiricamente elas podem ocorrer de forma sobreposta. A imagem e a reputação de um mesmo agente alvo podem ter valores diferentes, visto tratar-

\footnotetext{
${ }^{4}$ (CARBO et al., 2001; SEN e SAJJA, 2002; YU e SINGH, 2003; PUJOL et al., 2002; ROUCHIER et al., 2001; HUYNH et al., 2004; KLOS e LA POUTRÉ, 2004; FULLAM e BARBER, 2004) entre outros.
} 
se de objetos distintos, sendo o primeiro uma crença que resulta de uma avaliação de comportamento, e o segundo uma meta-crença, resultado da transmissão da crença original. As avaliações da imagem e da reputação são geradas a partir da comparação entre o comportamento do agente e as normas e costumes sociais que regem esse comportamento.

A figura 2.1 ilustra a formação da imagem e a difusão da reputação.

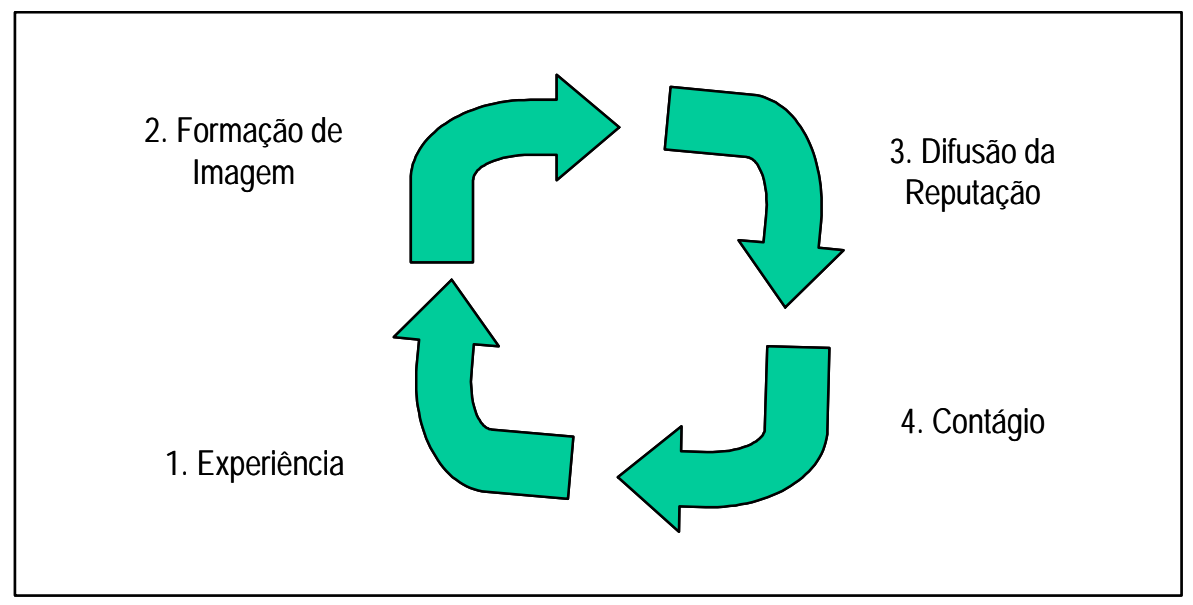

Figura 2.1: Formação da Imagem e Difusão da Reputação (CONTE e PAOLUCCI, 2002, p. 72)

Inicialmente, (1) a informação é adquirida através da experiência direta do agente. Em seguida, ocorre (2) a formação da imagem e (3) a difusão dessa imagem na forma de reputação. Finalmente, a presença da reputação pode (4) influenciar a experiência dos agentes, através do efeito que os autores chamam de contágio.

A imagem e a reputação envolvem três conjuntos de agentes, distintos e não disjuntos: as entidades avaliadoras (evaluators), as entidades alvos (target), as entidades beneficiárias (beneficiaries). Adicionalmente, a reputação envolve um quarto conjunto, aquele formado pelas entidades transmissoras (third-party). As entidades avaliadoras são aquelas capazes de formar uma avaliação, ou crença avaliadora, sobre as demais entidades, resultado das suas interações e percepções sociais. Entidades alvo são os indivíduos, grupos, ou mesmo artefatos, que são os objetos da avaliação. Entidades beneficiárias são os indivíduos, grupos, organizações que compartilham o objetivo (goal) a respeito do qual o agente alvo é avaliado e para os quais a avaliação do alvo traz algum tipo de benefício. As entidades transmissoras, ou terceira parte, são aquelas capazes de transmitir as informações sobre as reputações dos demais agentes (CONTE e PAOLUCCI, 2000, p. 73-78).

Conte e Paolucci (2002, p. 107) sugerem que há quatro aspectos envolvidos na decisão de um agente em transmitir uma reputação:

- por que transmitir - o agente pode decidir transmitir ou não uma reputação devido a diversos fatores, tais como a similaridade entre a imagem e a reputação 
do agente alvo, a reputação do agente avaliador, a responsabilidade social frente às conseqüências da transmissão;

- $\quad$ sobre quem transmitir - o agente pode decidir transmitir a reputação de uma entidade alvo devido à fama desta ou à distância social e física existente entre eles;

- $\quad$ para quem transmitir - a escolha do receptor pode ser influenciada por fatores tais como a proximidade física e social entre as entidades transmissora e receptora, a reciprocidade existente entre elas e o interesse da entidade receptora pela informação transmitida;

- como transmitir - a transmissão da reputação normalmente acontece em uma cadeia de interação entre os agentes, onde um agente recebe uma informação e a transmite para outros agentes.

Após ter decidido transmitir uma reputação, o agente deve escolher o que será transmitido, ou seja, decidir o conteúdo da informação (CONTE e PAOLUCCI, 2002, p.110). Uma entidade transmissora pode selecionar, inventar ou manipular a informação original de acordo com as restrições e oportunidades apresentadas pelas circunstâncias. Assim, a informação transmitida pode ser fiel à informação original, como também pode ser alterada devido a fatores como o cinismo, que provoca uma subestimação do valor da reputação, e o otimismo, que provoca uma superestimação do valor da reputação.

\subsubsection{Modelo Tipologia de Reputação de Mui et al. (2002a)}

Mui et al. (2002a, 2003) realizaram uma ampla revisão dos trabalhos sobre reputação desenvolvidos em diversas disciplinas- como Economia, Ciência da Computação e Biologia - e propuseram um arcabouço para sumarizar as noções existentes de reputação. Tal arcabouço, ao qual deram o nome de Tipologia de Reputação ${ }^{5}$ (typology of reputation), descreve a reputação por meio de duas dimensões de análise, segundo a natureza da entidade alvo e o tipo de informação utilizada na sua formação. Além disso, os autores ressaltam que a reputação depende do contexto no qual os indivíduos estão inseridos e do papel desempenhado por eles em tal contexto.

\footnotetext{
${ }^{5} \mathrm{O}$ termo tipologia foi adotado como tradução da palavra inglesa typology, usada pelos autores para designar uma estrutura intuitiva de super-conceitos - sub-conceitos relacionados à noção de reputação.
} 
A primeira dimensão diferencia a reputação de acordo com a natureza da entidade alvo, qual seja, indivíduo ou grupo de indivíduos, denominando Reputação Individual (individual reputation) a primeira e Reputação de Grupo (group reputation) a segunda.

A segunda dimensão aplica-se apenas à reputação de indivíduos e distingue a reputação segundo a sua fonte de informação. A tipologia denomina Reputação Direta (direct reputation) aquela derivada da experiência direta e Reputação Indireta (indirect reputation) aquela inferida a partir das evidências recebidas de segunda mão, tal como informações fornecidas por terceiros. O termo Reputação Direta é refinado através de duas noções, nomeadamente, a Reputação Derivada da Interação (interaction-derived reputation), que resulta dos encontros dos agentes, e a Reputação Observada (observed reputation), que é baseada na observação de um encontro entre agentes. O termo Reputação Indireta é detalhado por meio de três noções: a Reputação Derivada Anterior (prior-derived reputation), que resulta dos preconceitos sociais; a Reputação Derivada do Grupo (group-derived reputation), que é aquela que o agente herda de seu grupo social; e a Reputação Propagada (propagated reputation), que é aquela derivada das informações recebidas de outros agentes.

A figura 2.2 apresenta o diagrama do Modelo Tipologia de Reputação proposto por Mui et al. (2002a, 2003).

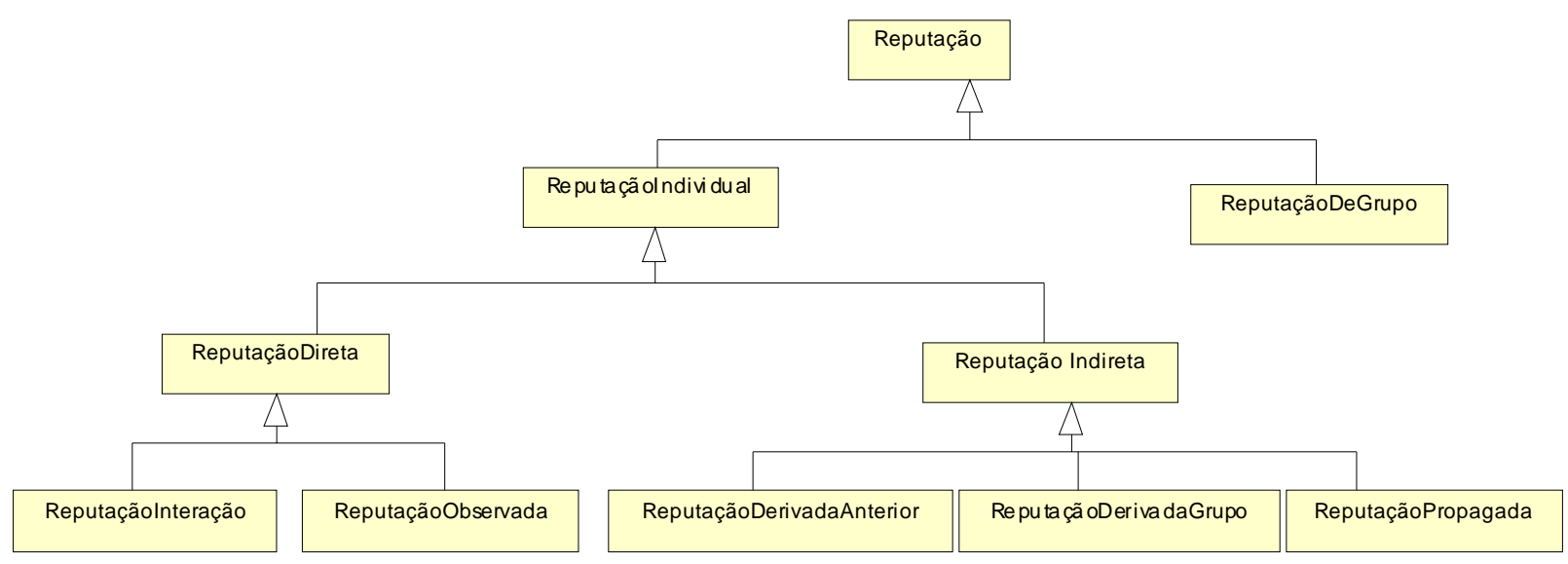

Figura 2.2: Modelo Tipologia de Reputação (MUI et al., 2003; p. 127)

\subsubsection{Sistemas Histos e Sporas de Zacharia e Maes (2000)}

Os sistemas de reputação Histos e Sporas (ZACHARIA et al., 1999; ZACHARIA e MAES, 2000) estão entre os primeiros sistemas computacionais propostos na área e por esta razão são amplamente citados pelas pesquisas posteriores. Trata-se de sistemas 
complementares para a avaliação da reputação dos indivíduos que participam como usuários do ambiente de comércio eletrônico Kasbah (CHAVEZ e MAES, 1996). Os autores ressaltam que apesar desses sistemas terem sido desenvolvidos para um ambiente de comércio eletrônico, eles podem ser utilizados em outros tipos de sistemas online, tais como ambientes de bate-papo e grupos de discussão.

Sporas (ZACHARIA e MAES, 2000) é um mecanismo de reputação para comunidades online com conexão fraca, e oferece um valor de reputação para cada usuário da comunidade, por meio das avaliações sobre as interações diretas fornecidas pelos usuários envolvidos. Neste sistema cada indivíduo tem uma única reputação, conhecida por todos os membros da comunidade.

Histos (ZACHARIA e MAES, 2000) é um mecanismo de reputação personalizada para comunidades online altamente conectadas, que considera as relações sociais existentes entre os usuários no cálculo da reputação. Tal abordagem compensa a falta de personalização da reputação no sistema Sporas, permitindo que um mesmo indivíduo tenha diversas reputações. A idéia de base do Histos é que os agentes sociais tendem a ter mais confiança nos amigos e nos amigos dos amigos, bem como nas informações por eles fornecidas, do que em uma pessoa estranha.

Tanto no Histos como no Sporas, após cada transação no ambiente de comércio eletrônico, o usuário avaliador fornece um valor de avaliação, que consiste em um número entre 0,1 e 1, representando respectivamente uma avaliação péssima ou ótima, que corresponde à avaliação do usuário alvo naquela transação.

O cálculo da reputação é realizado por um componente central, e não pelos próprios usuários, após a coleta das avaliações fornecidas. O valor da reputação do usuário avaliador é considerado no cálculo da reputação do usuário alvo, através da ponderação do valor da avaliação fornecida com o valor da sua reputação. Assim, a avaliação fornecida por um usuário de boa reputação tem maior influência na reputação do usuário alvo que aquelas avaliações fornecidas por avaliadores de reputação ruim. O valor da reputação varia entre 0 e 3000, onde 0 corresponde à reputação dos recém-chegados à comunidade e 3000 à melhor reputação possível. O valor máximo da reputação de um usuário é controlado por ambos sistemas, não permitindo que ultrapasse o teto de 3000 .

Histos e Sporas propõem um fator de depreciação da reputação, que dá mais importância às avaliações mais recentes em detrimento das mais antigas. Assim, uma eventual alteração no padrão de comportamento do usuário no decorrer do tempo pode ser rapidamente refletida no valor da sua reputação. 


\subsubsection{Sistema de Reputação Baseado em Papel Social de Carter et al. (2002)}

O Sistema de Reputação baseado em Papel Social proposto por Carter et al. (2002) apresenta uma formalização do conceito de reputação associada a papéis, onde a reputação depende da capacidade de desempenho de papéis sociais pelos indivíduos, que são os usuários do sistema. Tal sistema de reputação restringe-se aos sistemas de compartilhamento de informações, que são sistemas multiagentes nos quais os agentes de software têm como objetivo facilitar a troca de informações entre os indivíduos usuários do sistema. Esses agentes interagem a fim de compartilhar as informações requisitadas pelo usuário, e de descobrir quem são os usuários com interesses relacionados. Assim, a principal função dos agentes de software é facilitar a troca de informação entre os indivíduos que utilizam o sistema de compartilhamento de informações.

A reputação de um indivíduo depende da maneira como desempenha os papéis sociais que lhe são atribuídos no contexto do sistema de compartilhamento de informações. O sistema propõe cinco papéis sociais distintos, e apresenta métodos para calcular a reputação de um indivíduo a partir do grau de satisfação associado a cada papel. Os cinco papéis são:

- Papel de Provedor de Informação Social (social information provider): esse papel é desempenhado pelos indivíduos que fornecem regularmente informações sobre os seus amigos e conhecidos, na forma de recomendações. O grau de satisfação desse papel reflete a regularidade com a qual um indivíduo fornece recomendações sobre os demais;

- $\quad$ Papel Interativo (interactive role): esse papel é desempenhado pelos indivíduos que interagem com o sistema de compartilhamento de informações, refletindo o nível de utilização do mesmo. O grau de satisfação desse papel depende da quantidade de interações feitas pelo indivíduos;

- $\quad$ Papel de Provedor de Conteúdo (content provider): esse papel é desempenhado pelos indivíduos quando eles relatam para o sistema quais são suas áreas de interesse e habilidades específicas. O grau de satisfação desse papel reflete a veracidade do relato desses interesses e habilidades;

- $\quad$ Papel de Informante Administrativo (administrative feedback role): esse papel é desempenhado pelos indivíduos que avaliam a qualidade das recomendações fornecidas pelos demais indivíduos. Esse papel também é desempenhado pelos 
indivíduos que fornecem informações sobre as diversas funcionalidades do sistema, como a facilidade de uso e a estabilidade. O grau de satisfação desse papel reflete a freqüência com a qual um indivíduo fornece essas informações administrativas;

- $\quad$ Papel de Longevidade (longevity role): esse papel depende da agregação dos demais papéis. Neste caso, o grau de satisfação depende do valor médio da reputação em um determinado período de tempo.

Um usuário será premiado com uma boa reputação se apresentar um comportamento que satisfaça às expectativas associadas a esses cinco papéis sociais. Caso contrário, será punido com uma má reputação. Por exemplo, o sistema de compartilhamento de informações atribui uma boa reputação a João, caso ele desempenhe os seus cinco papéis sociais de forma adequada: João fornece recomendações de boa qualidade sobre os demais indivíduos (papel de provedor de informação), executa regularmente operações no sistema de compartilhamento de informações (papel interativo), relata corretamente as suas áreas de interesse (papel de provedor de conteúdo), avalia as recomendações recebidas e fornece informações sobre as funcionalidades do sistema (papel de informante administrativo) e, além disso, nos últimos seis meses manteve uma reputação média positiva (papel de longevidade).

A figura 2.3 mostra os componentes do sistema de reputação proposto, ilustrando a forma pela qual a reputação de um usuário é estabelecida a partir da avaliação do desempenho dos seus papéis sociais.

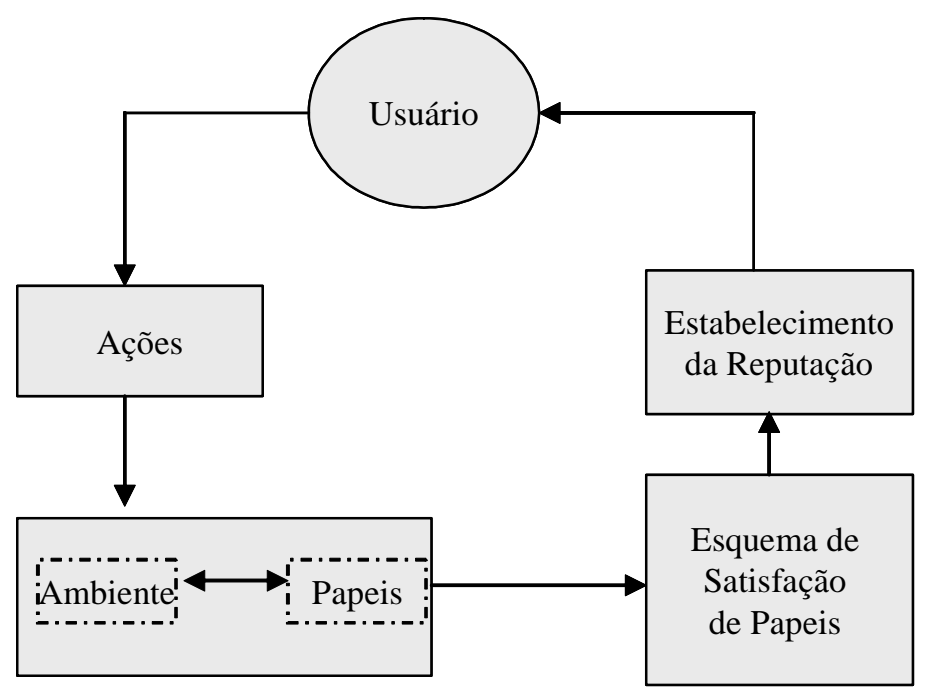

Figura 2.3: Componentes do Modelo de Reputação Baseado em Papel (CARTER et al., 2002; p. 520) 
A reputação de um indivíduo é calculada por um componente central do sistema, que monitora o comportamento dos usuários em relação aos seus desempenhos nos diversos papéis. O valor da reputação resulta da soma ponderada dos graus de satisfação de cada papel social e tem valor definido no intervalo [-1,1], onde -1 corresponde a uma péssima reputação e 1 a uma ótima reputação.

\subsubsection{Sistema de Reputação e Endosso de Maximilien e Singh (2002a)}

O Sistema de Reputação e Endosso (Reputation and Endorsement System - RES), proposto por Maximilien e Singh (2002a, 2002b), é um sistema de reputação para os serviços fornecidos via $\mathrm{Web}^{6}$ que utiliza uma arquitetura baseada em agentes de software inseridos em um sistema multiagentes. Esses agentes, chamados de Web Service Agent Proxy (WSAP), atuam como representantes do usuário no acesso aos serviços disponíveis na Web.

Os usuários deste sistema possuem um agente WSAP para cada serviço Web utilizado, através do qual ocorrem suas atividades em relação ao serviço. Além desses agentes WSAP, a arquitetura do sistema multiagentes utiliza as agências de reputação e de endosso, que são responsáveis pela coleta e fornecimento de informações sobre a reputação de um serviço Web. Os agentes WSAP executam diversas tarefas, tais como compartilhar o conhecimento com os demais agentes e com as agências de reputação e de endosso, ajudar a encontrar o fornecedor apropriado e registrar a avaliação do usuário após a utilização do serviço.

A avaliação que um usuário faz de um serviço Web reflete a sua experiência com aquele serviço por meio de um conjunto de atributos e seus respectivos valores e relevâncias. Assim, esta avaliação depende da visão subjetiva desse usuário, ou seja, depende dos atributos escolhidos e dos pesos associados por ele a cada atributo. Alguns exemplos de atributos são o preço do produto, a flexibilidade do fornecedor e a pontualidade na entrega. Os autores salientam que a escolha dos atributos para um determinado domínio de negócio não é uma tarefa trivial, devendo ser realizada pela comunidade de usuários e fornecedores.

\footnotetext{
${ }^{6}$ World Wide Web.
} 
Nesse sistema, a reputação de um serviço agrega as avaliações fornecidas pelos diversos usuários ao longo do tempo. Entretanto, essas avaliações não são consideradas como valores absolutos, e sim como uma função dos atributos envolvidos. Dessa forma, a reputação de um serviço é uma função dos diversos atributos que interessam determinado usuário, visto que o peso que este associa a cada atributo afeta o valor da reputação do serviço. Portanto, não é suficiente conhecer apenas o valor das avaliações feitas pelos demais usuários, pois é necessário também conhecer quais os atributos que a compõem, os pesos associados a eles e o significado semântico de cada atributo. Por exemplo, um serviço de aluguel de carros que pratica um preço mais alto que a concorrência, sendo, entretanto, mais flexível em relação aos locais de retirada e entrega dos carros, pode ser mais interessante para um usuário que está a trabalho do que para usuários em férias. Assim, um usuário em férias pode ter atribuído uma reputação ruim para esse serviço, porque deu mais importância ao preço do serviço do que à flexibilidade do local de entrega; contudo, ele pode ter atribuído um valor alto ao atributo flexibilidade. Um usuário a trabalho, que considera a avaliação feita pelo usuário em férias, pode chegar a um valor favorável de reputação do serviço, porque alterou os pesos dos atributos, considerando a flexibilidade mais importante do que o preço.

Cada atributo possui características como a unidade de medida utilizada (percentual, velocidade, quantidade, etc), os domínios de negócio aos quais pertence (viagem, livros, etc), o seu peso e o impacto do aumento ou diminuição de seu valor no valor da reputação. Além dos atributos, o valor da reputação depende do algoritmo de reputação, responsável pela integração das diversas avaliações realizadas ao longo do tempo. Tal algoritmo considera que as avaliações recentes devem ser mais relevantes do que as antigas.

A figura 2.4 apresenta, em Unified Modeling Language (UML), o modelo conceitual para reputação de serviço utilizado pelo Sistema de Reputação e Endosso. De acordo com este modelo, um serviço possui uma reputação que agrega o histórico das diversas avaliações feitas pelos usuários ao longo do tempo. Essas avaliações dependem dos atributos escolhidos, e dos pesos de cada um deles. Esses atributos estão associados a um determinado domínio, por exemplo, Viagem ou Varejo. O algoritmo de avaliação, que consolida os valores dos atributos e pesos, produz o valor da avaliação do serviço, enquanto o algoritmo de reputação agrega os diversos valores históricos da avaliação de um serviço, gerando o valor da reputação. 


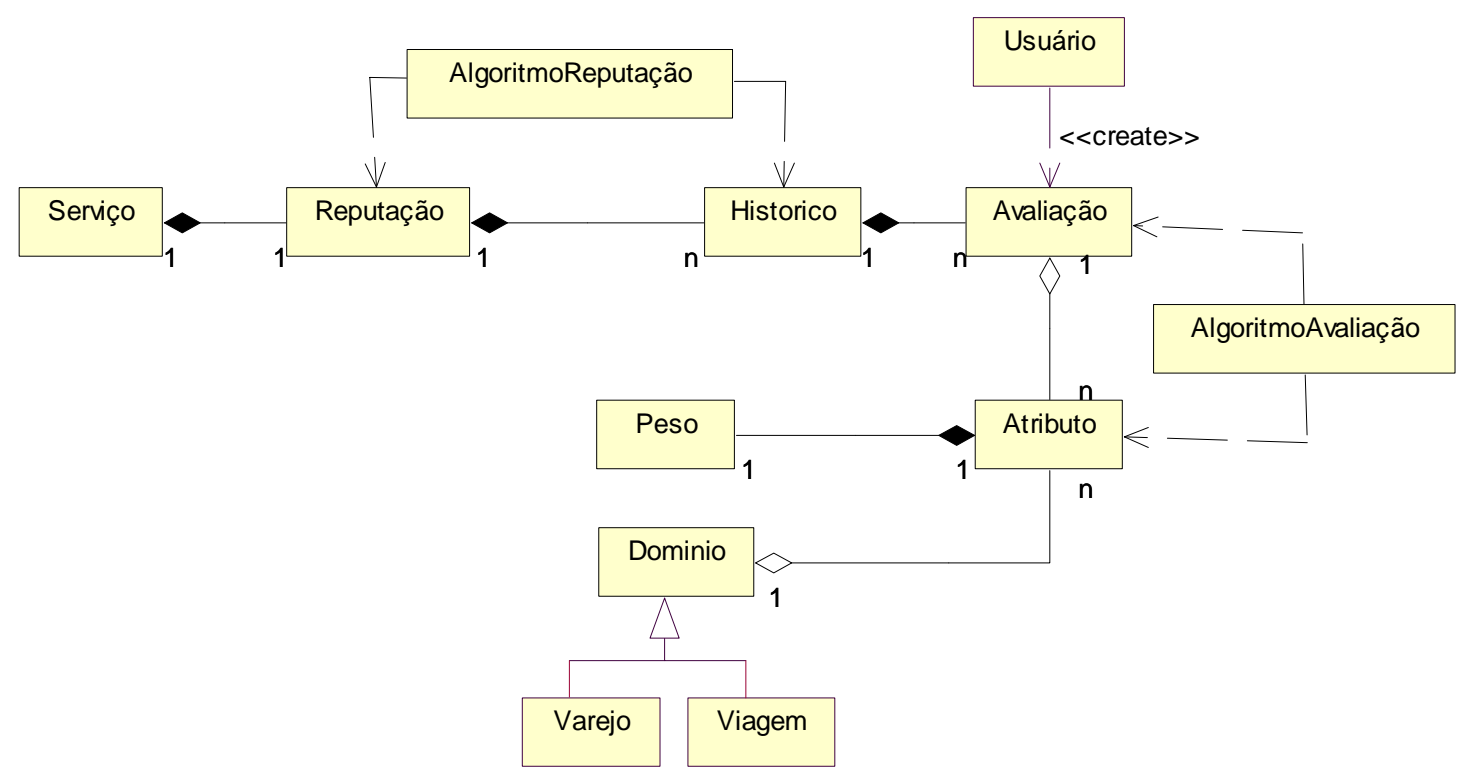

Figura 2.4: Parte do Modelo Conceitual em UML do Sistema de Reputação e Endosso (MAXIMILIEN e SINGH, 2002b)

\subsubsection{Sistema de Reputação e Confiança ReGret de Sabater (2003)}

O Sistema de Reputação e Confiança ReGret, proposto por Sabater (2003), foi desenvolvido para ambientes complexos de comércio eletrônico. Tal sistema valoriza os aspectos sociais envolvidos nos conceitos de reputação e confiança, levando em conta as estruturas sociais existentes entre os membros de uma sociedade na avaliação da reputação de um indivíduo.

O modelo de reputação utilizado considera diversas fontes de informação para a reputação, tais como a experiência direta dos indivíduos, as informações recebidas de terceiros e o grupo ao qual os indivíduos pertencem. A partir dessas fontes de informação o sistema ReGret gera quatro distintas avaliações sobre a reputação de um mesmo individuo, chamadas de Confiança Direta (direct trust), Reputação de Testemunha (witness reputation), Reputação de Vizinhança (neighborhood reputation) e Reputação de Sistema (system reputation). Essas avaliações são posteriormente consolidadas em uma avaliação chamada de Confiança (trust) (ver figura 2.5).

A Confiança Direta é a avaliação que resulta tanto da interação direta entre os agentes como da observação dessa interação. É considerada como uma propriedade 
subjetiva do agente e calculada como uma média ponderada dos resultados das interações passadas, onde as interações antigas têm um peso menor que as recentes.

A Reputação de Testemunha resulta das informações recebidas dos agentes transmissores que tiveram experiência direta com o agente alvo. O sistema ReGret considera que os agentes podem transmitir informações falsas, mentir e esconder informações relevantes, e permite que o agente receptor escolha os agentes transmissores dos quais quer receber informações. Um peso é associado à informação recebida, indicando dessa forma a credibilidade (credibility) do agente transmissor, a qual depende das suas relações sociais e sofre alterações se essas relações forem modificadas.

A Reputação de Vizinhança reflete o preconceito social associado ao agente alvo, enquanto a Reputação do Sistema baseia-se em características do grupo social ao qual o agente pertence, tal como a empresa na qual ele trabalha.

O valor dessas quatro avaliações é calculado a partir dos diversos atributos considerados na composição de cada uma delas. Exemplos desses atributos para um agente fornecedor são entregar o produto rapidamente, oferecer bons preços, oferecer boa qualidade e manter a quantidade prometida.

A Confiança (trust) no agente alvo resulta da escolha, e não de uma combinação, de uma dessas quatro avaliações. Esta escolha depende tanto da relevância como do grau de confiabilidade (reliability) associado a cada avaliação. Inicialmente, as quatro avaliações são classificadas em uma escala de relevância, na qual são consideradas mais relevantes a Confiança Direta e a Reputação de Testemunha, e menos relevantes a Reputação de Vizinhança e a Reputação de Sistema. Em seguida, é aplicada uma heurística para a escolha de uma das avaliações de acordo com seu grau de confiabilidade: se a avaliação mais relevante tiver um baixo grau de confiabilidade, considera-se a próxima avaliação da escala. Caso a última avaliação da escala, que é a reputação do sistema, tenha pouca confiabilidade, o sistema considera um valor padrão de reputação (default reputation), que é definido como um valor fixo e sempre disponível.

A figura 2.5 ilustra os conceitos envolvidos na escolha do valor da Confiança de um agente: a Confiança Direta; a noção de Credibilidade, que é associada à Reputação de Testemunha; e o Modelo de Reputação, composto pelas três avaliações de reputação (Reputação de Testemunha, Reputação de Vizinhança, Reputação de Sistema).

Este sistema lida com duas noções complementares: reputação e confiança. Mais detalhes sobre a noção de confiança, que não será abordada diretamente neste trabalho, podem ser encontrados na seção 2.3. 
A seguir, apresenta-se uma síntese dos modelos e sistemas de reputação apresentados nesta seção.

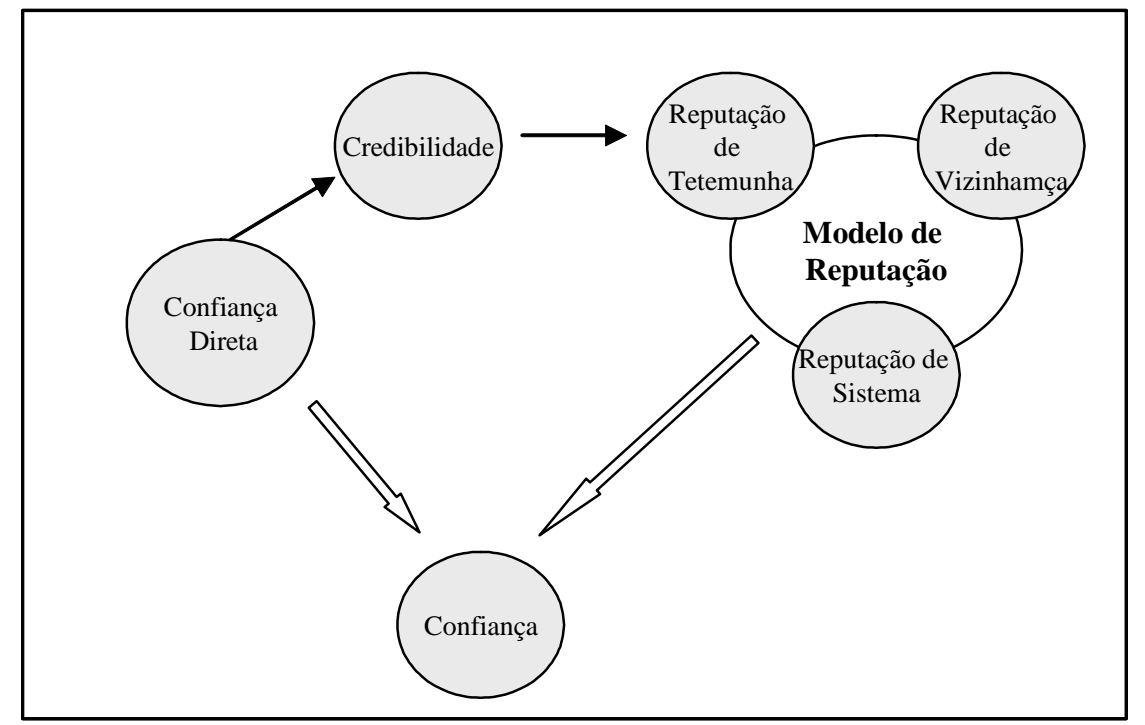

Figura 2.5: Visão Parcial do Sistema ReGret (SABATER, 2003, p. 42)

\subsubsection{Análise Comparativa dos Modelos e Sistemas de Reputação}

A análise comparativa dos modelos e sistemas de reputação apresentados nas seções anteriores necessita do estabelecimento de alguns critérios. Tais critérios foram definidos a partir (i) das noções de reputação propostas por Bromley (1993) e por Ferris et al. (2003), apresentadas na seção 2.1, e (ii) da definição das atribuições de um sistema de reputação segundo Resnick et al. (2000): um sistema de reputação é responsável por coletar, distribuir e agregar as informações sobre o comportamento passado de seus participantes. Tais critérios estão apresentados aqui de forma resumida, pois serão extensamente detalhados quando a Ontologia Funcional de Reputação for apresentada no capítulo 5. A descrição destes critérios pode também ser encontrada em (CASARE e SICHMAN, 2005a).

Os critérios de análise adotados na análise comparativa dos modelos e sistemas de reputação são os seguintes:

- $\quad$ Natureza da reputação - permite identificar a que tipo de entidade a reputação se aplica. Por exemplo, trata-se de uma reputação de individuo, de grupo, de produto, de serviço;

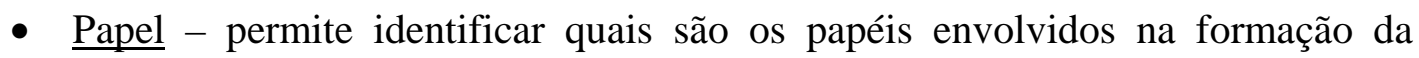
reputação. Por exemplo, papel de alvo, papel de avaliador ou papel de transmissor da reputação; 
- Tipo da reputação - permite classificar a reputação a partir da fonte de informação utilizadas na sua formação: reputação primária, se baseada no contato direto com o indivíduo observado; ou reputação secundária, se baseada em relato de terceiros;

- Valor da reputação - permite identificar o tipo do valor da reputação: valor consolidado ou valor detalhado por meio de atributos;

- Fator de avaliação - permite identificar quais são os fatores considerados na avaliação da reputação, além do comportamento do agente. Por exemplo, a reputação da entidade que forneceu a informação ou as relações sociais existentes entre os agentes;

- Manutenção da reputação - permite identificar o método utilizado para agregar os diversos valores da reputação ao longo do tempo;

- Distribuição da reputação - permite identificar o método utilizado para a propagação da reputação. Por exemplo, se existe uma entidade responsável pela coleta e distribuição da informação ou se esta pode ser realizada por qualquer um.

A tabela 2.1 apresenta a comparação dos modelos e sistemas de reputação estudados, segundo os critérios de análise apresentados acima.

Tabela 2.1: Comparação dos modelos e sistemas de reputação

\begin{tabular}{|c|c|c|c|c|c|c|c|}
\hline Modelo & Natureza & Papel & $\begin{array}{c}\text { Tipo de } \\
\text { Reputação }\end{array}$ & $\begin{array}{c}\text { Valor } \\
\text { Avaliação }\end{array}$ & $\begin{array}{l}\text { Fator de } \\
\text { avaliação }\end{array}$ & Manutenção & Distribuição \\
\hline $\begin{array}{c}\text { Modelo } \\
\text { Cognitivo } \\
\text { de } \\
\text { Reputação } \\
\text { (Conte e } \\
\text { Paolucci) }\end{array}$ & $\begin{array}{c}\text { Reputação } \\
\text { de } \\
\text { Individuo }\end{array}$ & $\begin{array}{c}\text { Alvo, } \\
\text { Avaliador, } \\
\text { Transmissor; } \\
\text { Receptor }\end{array}$ & $\begin{array}{l}\text { Primária e } \\
\text { Secundária }\end{array}$ & $\begin{array}{c}\text { Valor } \\
\text { consolidado }\end{array}$ & & & $\begin{array}{c}\text { Distribuiçãa } \\
\text { resulta de } \\
\text { processo de } \\
\text { decisão; } \\
\text { Trata } \\
\text { fidelidade da } \\
\text { informação }\end{array}$ \\
\hline $\begin{array}{c}\text { Modelo } \\
\text { Tipologia } \\
\text { de } \\
\text { Reputação } \\
\text { (Mui et al.) }\end{array}$ & $\begin{array}{c}\text { Reputação } \\
\text { de } \\
\text { Individuo; } \\
\text { Reputação } \\
\text { de Grupo } \\
\end{array}$ & & $\begin{array}{l}\text { Primária e } \\
\text { Secundária }\end{array}$ & & & & \\
\hline $\begin{array}{l}\text { Sistema } \\
\text { Histos } \\
\text { (Zacharia e } \\
\text { Maes) }\end{array}$ & $\begin{array}{c}\text { Reputação } \\
\text { de } \\
\text { Individuo }\end{array}$ & $\begin{array}{l}\text { Alvo, } \\
\text { Avaliador }\end{array}$ & $\begin{array}{c}\text { Não } \\
\text { distingue }\end{array}$ & $\begin{array}{c}\text { Valor } \\
\text { consolidado }\end{array}$ & $\begin{array}{l}\text { Reputação } \\
\text { do avaliador; } \\
\text { Relação } \\
\text { Social }\end{array}$ & $\begin{array}{c}\text { Valoriza } \\
\text { resultado } \\
\text { mais recente }\end{array}$ & $\begin{array}{c}\text { Componente } \\
\text { central } \\
\text { distribui para } \\
\text { usuários } \\
\end{array}$ \\
\hline $\begin{array}{c}\text { Sistema } \\
\text { Sporas } \\
\text { (Zacharia e } \\
\text { Maes) }\end{array}$ & $\begin{array}{c}\text { Reputação } \\
\text { de } \\
\text { Individuo }\end{array}$ & $\begin{array}{l}\text { Alvo, } \\
\text { Avaliador }\end{array}$ & $\begin{array}{c}\text { Não } \\
\text { distingue }\end{array}$ & $\begin{array}{c}\text { Valor } \\
\text { consolidado }\end{array}$ & $\begin{array}{l}\text { Reputação } \\
\text { do avaliador }\end{array}$ & $\begin{array}{c}\text { Valoriza } \\
\text { resultado } \\
\text { mais recente }\end{array}$ & $\begin{array}{c}\text { Componente } \\
\text { central } \\
\text { distribui para } \\
\text { usuários }\end{array}$ \\
\hline
\end{tabular}




\begin{tabular}{|c|c|c|c|c|c|c|c|}
\hline Critério & Natureza & Papel & $\begin{array}{c}\text { Tipo de } \\
\text { Reputação }\end{array}$ & $\begin{array}{c}\text { Valor } \\
\text { Avaliação }\end{array}$ & $\begin{array}{l}\text { Fator de } \\
\text { avaliação }\end{array}$ & Manutenção & Distribuição \\
\hline $\begin{array}{c}\text { Sistema } \\
\text { Reputação } \\
\text { cl papéis } \\
\text { (Carter et } \\
\text { al.) }\end{array}$ & $\begin{array}{c}\text { Reputação } \\
\text { de } \\
\text { Individuo }\end{array}$ & $\begin{array}{l}\text { Alvo, } \\
\text { Avaliador }\end{array}$ & $\begin{array}{c}\text { Não } \\
\text { distingue }\end{array}$ & $\begin{array}{c}\text { Valor } \\
\text { consolidado }\end{array}$ & Papel Social & $\begin{array}{c}\text { Valoriza } \\
\text { resultado } \\
\text { mais recente }\end{array}$ & $\begin{array}{l}\text { Componente } \\
\text { central } \\
\text { distribui para } \\
\text { usuários }\end{array}$ \\
\hline $\begin{array}{c}\text { Sistema de } \\
\text { Reputação } \\
\text { e Endosso } \\
\text { (Maximilien } \\
\text { e Singh) }\end{array}$ & $\begin{array}{c}\text { Reputação } \\
\text { de serviço } \\
\text { Web }\end{array}$ & $\begin{array}{c}\text { Alvo, } \\
\text { Avaliador, } \\
\text { Transmissor, } \\
\text { Receptor }\end{array}$ & $\begin{array}{c}\text { Não } \\
\text { distingue }\end{array}$ & $\begin{array}{l}\text { Valor } \\
\text { detalhado } \\
\text { (atributos e } \\
\text { pesos) }\end{array}$ & & $\begin{array}{c}\text { Valoriza } \\
\text { resultado } \\
\text { mais recente }\end{array}$ & $\begin{array}{l}\text { Agência de } \\
\text { reputação } \\
\text { distribui os } \\
\text { valores dos } \\
\text { atributos } \\
\text { para agente } \\
\text { do usuário }\end{array}$ \\
\hline $\begin{array}{c}\text { Sistema } \\
\text { ReGret } \\
\text { (Sabater) }\end{array}$ & $\begin{array}{c}\text { Reputação } \\
\text { de } \\
\text { Individuo }\end{array}$ & $\begin{array}{c}\text { Alvo, } \\
\text { Avaliador, } \\
\text { Transmissor, } \\
\text { Receptor }\end{array}$ & $\begin{array}{l}\text { Primária e } \\
\text { Secundária }\end{array}$ & $\begin{array}{c}\text { Valor } \\
\text { detalhado } \\
\text { (atributos) }\end{array}$ & $\begin{array}{c}\text { Credibilidade } \\
\text { do } \\
\text { transmissor }\end{array}$ & $\begin{array}{c}\text { Valoriza } \\
\text { resultado } \\
\text { mais recente }\end{array}$ & \\
\hline
\end{tabular}

\subsection{Reputação como Componente da Noção de Confiança}

\subsubsection{Introdução}

A confiança é definida pelo Dicionário Aurélio (FERREIRA, 1986) como “a segurança de procedimento, o bom conceito que inspiram as pessoas de probidade, talento, discrição, etc”. Depositar confiança em alguém significa “crer na sua honradez ou discrição, tendo a pessoa em alta estima”.

Ostrom (1998) define a confiança como sendo a expectativa que uma pessoa tem sobre a ação das outras pessoas. Barber et al. (2003) propõem uma definição de confiança para o mundo dos agentes: a confiança é a convicção (confidence) de alguém nas habilidades e intenções de um agente em prover informações corretas ou executar as ações prometidas. Para um agente, o ato de confiar deveria ser refletido na sua disposição para interagir com outro agente, a fim de alcançar seus objetivos.

A noção de confiança é fundamental tanto para a noção de agência como para os sistemas multiagentes. É um conceito crítico para os modelos de conhecimento distribuído e de circulação de conhecimento, assim como para os modelos que envolvem questões de equilíbrio entre o interesse individual do agente e o interesse coletivo e global da 
sociedade, tais como os modelos de grupos e times, de organizações, de coordenação e de negociação (CASTELFRANCHI e FALCONE, 2001).

Segundo Barber et al. (2003), modelos de confiança têm como objetivo sustentar a decisão do agente de cooperar ou não com os demais agentes em um determinado contexto, visto que em certos ambientes a cooperação pode expor o agente a riscos. Em outras palavras, um modelo de confiança deve (i) permitir ao agente avaliar os riscos envolvidos em uma cooperação com outro agente, (ii) escolher a melhor parceria e (iii) revisar o resultado das cooperações, a fim de aprender e atualizar o seu modelo de confiança (CASTELFRANCHI et al., 2000b).

A literatura apresenta vários sistemas de confiança que incluem a reputação como um dos fatores envolvidos na emergência da confiança (SEN e SAJJA, 2002; CASTELFRANCHI et al., 2003a; SABATER, 2003; CARBO et al., 2001, 2003; MUI et al., 2002b, entre outros).

A seguir, são apresentados dois exemplos da utilização da reputação como parte da noção de confiança: o Modelo de Comportamento para Ações Sociais, proposto por Ostrom (1998, 2000) e o Modelo Sócio-Cognitivo de Confiança proposto por Castelfranchi et al. (2003a, 2003b). O primeiro, definido em linguagem natural, mostra como a confiança e a reputação podem explicar o comportamento dos indivíduos em suas interações sociais. A descrição deste modelo é complementada com a apresentação do Modelo Computacional de Confiança (Computational Model of Trust) (MUI et al., 2002b), inspirado no trabalho de Ostrom (1998). O segundo modelo propõe um mecanismo de cálculo para o valor da confiança, no qual a reputação é um dos fatores considerados.

\subsubsection{Modelo de Comportamento para Ação Social de Ostrom (1998)}

Elinor Ostrom $(1998,2000)$ propôs um modelo qualitativo de comportamento para as ações sociais no qual a confiança, a reciprocidade e a reputação são atributos importantes na explicação do comportamento dos indivíduos em dilemas sociais.

O termo “dilema social” se refere a um grande número de situações nas quais os indivíduos fazem escolhas independentes em situações interdependentes. Essas situações são consideradas dilemas porque existe pelo menos um resultado que produz uma vantagem maior para todos os participantes. Dilemas sociais, dos quais um dos exemplos mais conhecidos é o Dilema do Prisioneiro (AXELROD, 1997), ocorrem quando os 
indivíduos, em situações interdependentes, possuem escolhas nas quais a maximização dos próprios interesses em curto prazo produz resultados que deixam os demais participantes em uma situação relativamente ruim, considerando as alternativas possíveis.

Segundo Ostrom (1998), a reputação é a identidade que os indivíduos criam e que projeta suas intenções e normas ${ }^{7}$, enquanto a confiança é a expectativa de uma pessoa sobre a ação das outras pessoas quando esta ação afeta as suas próprias escolhas. A reciprocidade consiste em uma classe importante de normas e se refere a uma família de estratégias que podem ser usadas em dilemas sociais. Essas estratégias consideram (i) o esforço para identificar quem mais está envolvido, (ii) a avaliação da possibilidade dos outros serem cooperadores condicionais, (iii) a decisão de cooperar inicialmente com os outros, caso eles sejam confiáveis como cooperadores condicionais, (iv) a recusa em cooperar com aqueles que não cooperam e (v) a punição daqueles que traem a confiança.

O relacionamento entre reciprocidade, reputação e confiança é central neste modelo e em linhas gerais se passa da seguinte forma. No centro da explicação do comportamento de um indivíduo estão os relacionamentos entre a confiança que esse indivíduo tem nos demais, o investimento feito por ele para ter uma reputação de ser confiável e a probabilidade dos participantes utilizarem as normas de reciprocidade. Quando muitos indivíduos usam a reciprocidade, existe um incentivo para adquirir uma reputação de mantenedor de promessas e compromissos, e de executor de ações que trazem custos no curto prazo e benefícios no longo prazo. Assim, a reputação de ser confiável ou de retribuir o tratamento a aqueles não cooperativos que não cumprem os acordos torna-se um recurso valioso para o indivíduo.

Mui et al. (2002b) desenvolveram um modelo computacional de confiança inspirado no modelo de comportamento proposto por Ostrom (1998). Tal modelo explicita, através de formulas matemáticas, a diferença entre confiança e reputação, e propõe um mecanismo probabilístico de inferência entre confiança, reputação e nível de reciprocidade.

Neste modelo, a reputação é descrita como a percepção relacionada às ações passadas do agente, e é representada como uma quantidade que depende da rede social do agente alvo e do histórico de seus encontros sociais.

\footnotetext{
${ }^{7}$ Uma norma (norm) é uma apreciação - positiva ou negativa - que um indivíduo associa a um tipo específico de ação.
} 
A confiança é descrita como a expectativa subjetiva que um agente possui sobre o comportamento futuro de um outro agente, baseada no histórico dos encontros ocorridos entre eles, e é representada como um valor inferido a partir da reputação do agente alvo.

A reciprocidade é a troca mútua de feitos e ações, tais como favores ou revanches, e pode ser medida de duas formas. Por um lado, ela pode ser vista como uma norma social disseminada e compartilhada pelos agentes de uma sociedade. Neste caso, quanto mais disseminada for a reciprocidade na sociedade, mais provável será a seleção aleatória de um agente engajado em ações recíprocas. Por outro lado, a reciprocidade pode ser considerada como um valor associado ao relacionamento entre dois agentes. Neste caso, quanto mais alto este valor, maior a probabilidade destes dois agentes se engajarem em ações de reciprocidade um com o outro.

A idéia na base do modelo proposto por Mui et al. (2002b) é que existem relacionamentos de reforço (reinforcing relationship) entre confiança, reputação e reciprocidade:

- um aumento na reputação de um agente pode melhorar a confiança que os demais agentes têm nele;

- um aumento na confiança depositada em um agente pode melhorar a probabilidade de que este agente aja segundo as normas de reciprocidade;

- um aumento das ações recíprocas pode melhorar a reputação de um agente.

A figura 2.6 ilustra o relacionamento de reforço entre confiança, reputação e reciprocidade. A direção das setas indica o sentido da influência entre estas noções.

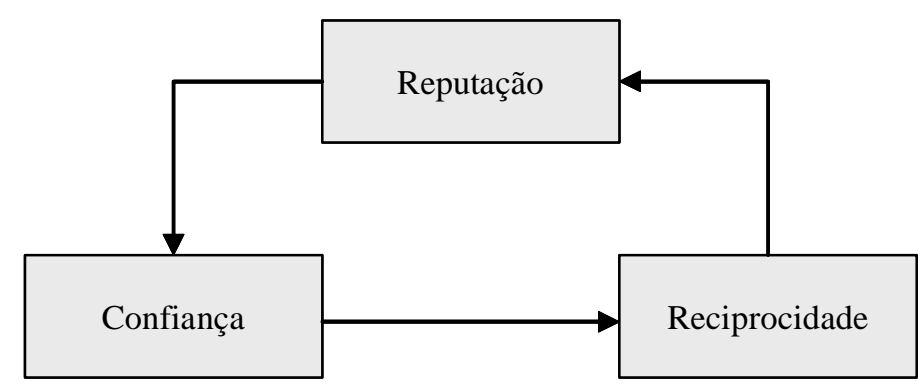

Figura 2.6: Representação dos relacionamentos entre Confiança, Reciprocidade e Reputação (Mui et al., 2002b)

\subsubsection{Modelo Sócio-Cognitivo de Confiança de Castelfranchi et al. (2003a)}

Castelfranchi et al. (2003a, 2003b) e Falcone et al. (2003) propuseram uma abordagem sócio-cognitiva para a confiança, por meio de um modelo baseado nas crenças 
e nas suas respectivas credibilidades. Os autores definem a confiança como um estado mental de um agente, uma crença, e enfatizam a importância de uma análise cognitiva da mesma, capaz de distinguir entre os fatores internos, que são as habilidades, as competências e a disposição ${ }^{8}$ de um agente, e os fatores externos, que são as oportunidades e as condições apresentadas pela ocasião.

A análise desses dois tipos de fatores conduz ao estabelecimento de diferentes estratégias, tanto para formar quanto para aumentar a confiança, visto que além da avaliação da disposição e habilidades do agente é necessário analisar a probabilidade de ocorrência de obstáculos, adversidades e interferências. A probabilidade de sucesso de um agente ao executar uma determinada ação deve ser decomposta na probabilidade de o agente executar bem a ação, dependente dos fatores internos, e na probabilidade de ele poder agir em condições apropriadas, dependentes dos fatores externos. A distinção entre os fatores internos e externos traz diversos benefícios, tal como entender porque a noção de confiança não pode ser simplesmente reduzida ou substituída por uma probabilidade ou uma medida de risco.

A confiança é detalhada por meio de dois sub-componentes, as fontes de crenças e as crenças propriamente ditas. O grau de confiança do agente avaliador no agente alvo depende da relevância dada a cada sub-componente.

O primeiro sub-componente, que se refere às fontes de crenças do agente avaliador, envolve os seguintes conceitos:

- a experiência direta (direct experience) - indica como a experiência individual, tanto positiva como negativa, do agente avaliador com o agente alvo influencia as crenças do primeiro em relação ao segundo;

- a reputação (reputation) - indica de que forma as demais experiências e as opiniões recebidas influenciam as crenças do agente avaliador;

- a categorização (categorization) - indica como as características que um agente alvo herda da classe da qual é membro influenciam a crença do agente avaliador;

- o raciocínio (reasoning) do agente - indica de que forma o agente raciocina com as diversas informações de que dispõe.

O segundo sub-componente, que se refere às crenças propriamente ditas, envolve:

\footnotetext{
${ }^{8}$ No sentido de persistência e engajamento.
} 
- os fatores internos, que são as crenças na habilidade (ability) ou competência (competence), disponibilidade (availability) e nocividade (harmfulness) do agente alvo;

- os fatores externos, que são as crenças nas oportunidades (opportunity) e condições apropriadas para a ação do agente alvo, assim como a crença no perigo (danger) dessas condições.

O cálculo do valor da confiança é feito por um mapa nebuloso cognitivo (Fuzzy Cognitive Maps) (KOSKO, 1986), consistindo em um sistema nebuloso aditivo com retroalimentação, capaz de representar um sistema dinâmico com relações de causa e efeito. Essas relações são representadas por meio dos componentes do mapa, que são os nós, as arestas e os respectivos valores. Os nós representam as causas e as arestas representam o poder causal de um nó sobre um outro nó.

A figura 2.7 ilustra um mapa cognitivo nebuloso definido para calcular a confiança (trustfulness) em um sistema médico automático.

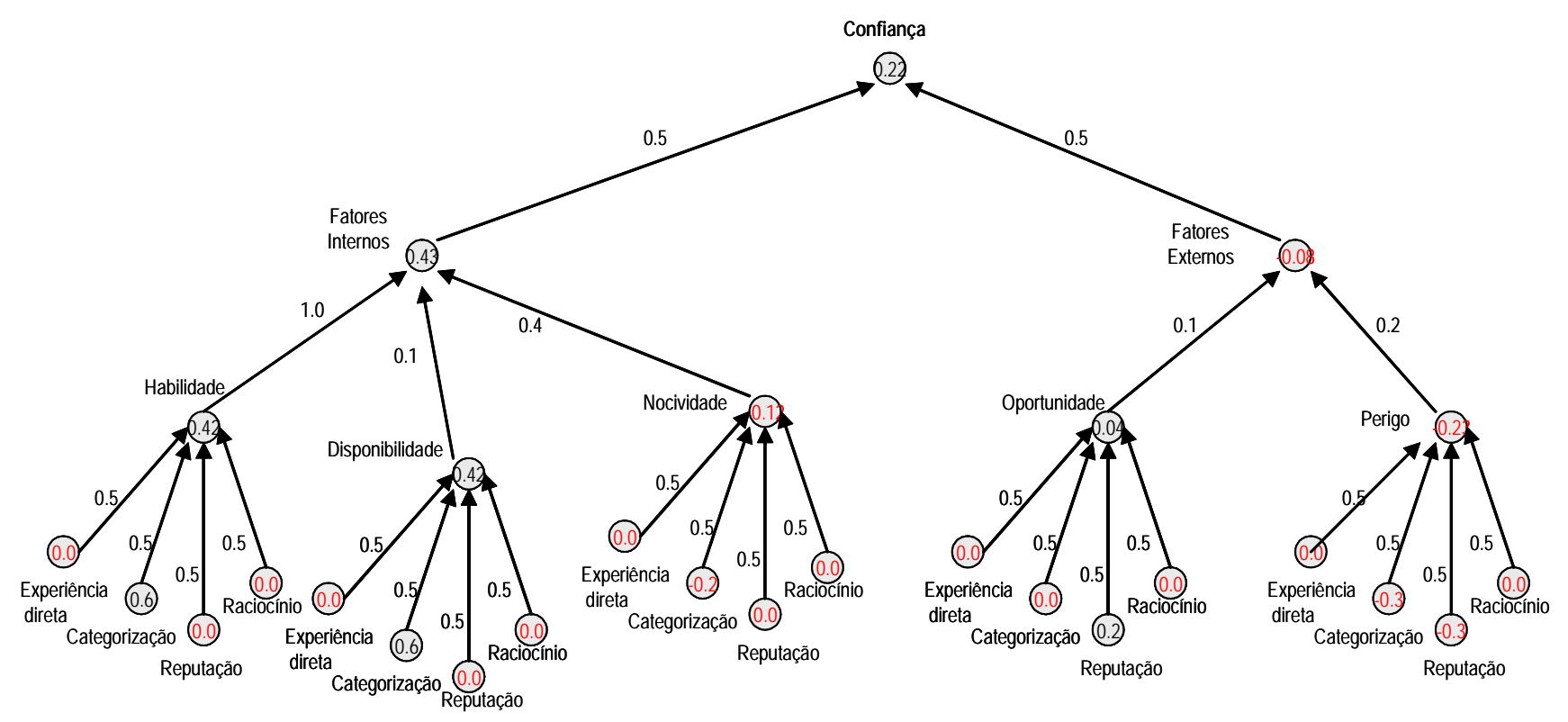

Figura 2.7: Mapa Nebuloso Cognitivo para um Sistema Médico (CASTELFRANCHI et al., 2003a)

Este mapa nebuloso contém quatro camadas de nós e arestas. Os nós da primeira camada (de baixo para cima) representam as fontes de crença (experiência direta, categorização, reputação e raciocínio). Os nós da segunda camada representam as crenças propriamente ditas (habilidade, disponibilidade, nocividade, oportunidade e perigo), enquanto os nós da terceira camada classificam as crenças como fatores internos ou externos. A última camada representa a confiança no agente alvo, calculada a partir dos valores dos nós e arestas definidos na primeira camada, que representam as fontes de 
crença. Ao final da execução do mapa nebuloso cognitivo o nó da quarta camada contém o valor da confiança no agente alvo, que pode variar qualitativamente entre baixa, media e boa.

\subsection{Considerações Finais}

Este capítulo apresentou diversos aspectos relacionados à noção de reputação de acordo com os estudos realizados no campo das Ciências Humanas. Além disso, foram apresentados vários modelos e sistemas de reputação e de confiança desenvolvidos no campo da Inteligência Artificial. A escolha destes modelos e sistemas deveu-se à originalidade da solução proposta e a sua importância para o desenvolvimento da Ontologia Funcional de Reputação, na medida que oferecem sugestões para a representação dos aspectos associados à noção de reputação. A seguir, são apresentadas algumas características que influenciaram na escolha destes modelos e sistemas. Parte destas características foi agregada à Ontologia Funcional de Reputação descrita no capítulo 5 deste texto.

- O Modelo Cognitivo de Reputação, proposto por Conte e Paolucci (2002), apresenta uma definição detalhada e original do processo de transmissão da reputação e dos conjuntos de agentes envolvidos em tal processo;

- O Modelo Tipologia de Reputação, desenvolvido por Mui et al. (2002a), especifica duas importantes dimensões da reputação, quais sejam, a natureza da reputação e as suas fontes de informações;

- O Sistema Histos, proposto por Zacharia e Maes (2000), ressalta a importância das relações sociais no processo de avaliação da reputação, considerando que os agentes tendem a ter mais confiança em um amigo, ou em um amigo de um amigo, do que em uma pessoa estranha;

- O Sistema de Reputação baseado em Papel Social, proposto por Carter et al. (2002), ressalta a importância dos papéis sociais na avaliação da reputação, implementando um modelo no qual a reputação depende do desempenho desses papéis;

- O Sistema de Reputação e Endosso, desenvolvido por Maximilien e Singh (2002b), propõe uma forma de compor o valor da reputação de um serviço por meio de atributos e seus respectivos pesos; 
- O Sistema de Reputação e Confiança ReGret, desenvolvido por Sabater (2003), ressalta a importância da análise das estruturas sociais existentes entre os membros de uma sociedade para a avaliação da reputação, além de mostrar como a reputação pode ser usada para gerar a confiança;

- O Modelo Sócio-Cognitivo de Confiança, proposto por Castelfranchi et al. (2003a), enfatiza a importância dos fatores internos (habilidades, competências e disposição) e dos fatores externos (oportunidades e condições) na análise do comportamento do agente;

- O Modelo de Comportamento para a Ação Social, proposto por Ostrom (1998), mostra como a reputação, a confiança e a reciprocidade podem ser fatores decisivos no comportamento social dos indivíduos.

O estudo e a análise desses modelos e sistemas de reputação mostrou que eles apresentam abordagens interessantes, mas parciais, dos diversos aspectos da reputação. A dificuldade para representar e modelar esses aspectos não se encontra apenas no campo da IA, mas também nas Ciências Humanas. A reputação faz parte do sistema de crenças dos membros de um grupo social e, portanto, essa dificuldade se deve ao caráter subjetivo das crenças sociais e da percepção das pessoas, e aos sistemas complexos que regem a convivência em grupo. As pesquisas realizadas por Bromley (1993) lançam algumas luzes sobre a noção de reputação, mas apresentam uma análise quantitativa ainda insuficiente para propiciar a construção de uma teoria. Ferris et al. (2003) citam algumas direções para as pesquisas futuras. Entre elas, está o desafio de desenvolver uma teoria de reputação que articule com maior precisão os antecedentes, as conseqüências, os moderadores e os mediadores envolvidos nesse processo.

Como dito anteriormente na seção 1.2, o objetivo deste trabalho é a construção de uma Ontologia Funcional de Reputação. Neste capítulo, os principais aspectos referentes à reputação foram apresentados. No próximo capítulo, aborda-se a definição e uso de ontologias em IA. 


\section{Ontologias}

Este capítulo procura responder às seguintes questões: O que são ontologias? Para que servem? Como desenvolvê-las? Tais respostas são fornecidas dentro da perspectiva de IA. Para tanto, apresenta-se um panorama dos elementos que fazem parte da construção de ontologias: metodologias, linguagens, ambientes de desenvolvimento e motores de inferência.

O capitulo segue a seguinte organização. Inicialmente apresenta-se uma discussão sobre a definição do termo ontologia e o papel das ontologias na representação do conhecimento. A seção 3.2 apresenta as metodologias para o desenvolvimento de ontologias. A seção 3.3 apresenta um panorama das linguagens de implementação de ontologias. As seções 3.4 e 3.5 descrevem, respectivamente, os ambientes de edição e construção e os mecanismos de raciocínio automático sobre ontologias. Finalmente, a seção 3.6 apresenta as considerações finais deste capítulo.

\subsection{Introdução}

\subsubsection{Definição de Ontologia}

O termo Ontologia designa originalmente uma das áreas de estudo da Filosofia, a área que se ocupa do conhecimento dos princípios e fundamentos últimos da realidade e dos seres (CHAUI, 1999). O termo utilizado inicialmente para designar essa área de estudo foi Metafísica, e o uso do termo Ontologia como sinônimo de Metafísica foi introduzido no século XVII pelo filósofo alemão Jacobus Thomasius.

A palavra Ontologia é composta por duas outras, onto e logia, e significa "o estudo ou o conhecimento do Ser, dos entes e das coisas tais como são em si mesmas, real e verdadeiramente, correspondendo ao que Aristóteles chamara de filosofia primeira, isto é , o estudo do Ser enquanto Ser”(CHAUI, 1999, p.183).

Após ficar restrito durante séculos à esfera da Filosofia, o termo Ontologia ganhou um significado específico em áreas como a IA, a Computação Lingüística e a Teoria de Banco de Dados, tendo a sua importância reconhecida em campos de pesquisa diversos como Engenharia do Conhecimento, Representação do Conhecimento, Análises Orientadas 
a Objetos e Desenho de Sistemas Baseados em Agentes (GUARINO, 1995). No inicio dos anos 80, pesquisadores em IA (especialmente em Representação do Conhecimento) perceberam que as ontologias desempenhavam um papel importante no processo de descrever o mundo, descrição esta essencial para que os sistemas inteligentes possam raciocinar e agir sobre esse mundo (WELTY e GUARINO, 2001). Valente (1995, p. 35) sugere que o termo Ontologia como é usado em IA está mais próximo daquilo que a Filosofia chama de Teoria Ontológica, uma teoria formada por conceitos genéricos, ou categorias ontológicas, que representam os componentes de um mundo. Ressalta que a formulação de uma teoria ontológica completa e coerente é um ideal a ser buscado, e não a realidade normalmente alcançada.

Segundo Guarino (1995), uma ontologia se refere a um artefato de Engenharia constituído por dois componentes: (i) um vocabulário específico usado para descrever uma certa realidade e (ii) um conjunto de pressupostos explícitos sobre o significado desse vocabulário. Esses pressupostos podem ser apresentados como uma teoria em lógica de primeira ordem, onde as palavras do vocabulário aparecem como nomes de predicados unários ou binários, chamados respectivamente de conceitos e relações. Ontologias que apresentam essa característica são algumas vezes chamadas de ontologias formais.

Segundo Gruber (1993), uma ontologia é uma especificação explícita de uma conceitualização, sendo que uma conceitualização é uma visão abstrata do mundo que se deseja representar, consistindo nos objetos, nos conceitos e nas relações entre eles, que existem no mundo representado. A especificação de uma conceitualização consiste em definir os axiomas que restringem e limitam a interpretação da entidade, além de descrever essas entidades em linguagem natural. Dessa forma, uma ontologia associa o nome de uma entidade com uma descrição em linguagem natural do significado desse nome, restringindo e limitando essa definição por meio de axiomas formais. Formalmente, uma ontologia é uma sentença (statement) de uma teoria lógica.

A definição de ontologia adotada neste trabalho é aquela proposta por Uschold e Gruninger (1996), segundo a qual uma ontologia engloba uma visão específica do mundo relativa a um domínio particular. Tal visão do mundo, também chamada de conceitualização, é geralmente concebida como um conjunto de conceitos, tais como entidades, atributos e processos, com suas respectivas definições e relacionamentos. Uma ontologia pode ter várias formas, mas deve incluir necessariamente um vocabulário de termos e as respectivas definições de significado. Como varia muito o grau de formalização 
desse vocabulário e de seus significados, os autores definiram uma escala de avaliação composta de quatro níveis de formalização de ontologias:

a) altamente informal - vocabulário em linguagem natural desestruturada;

b) semi-informal - vocabulário em linguagem natural estruturada e restrita, reduzindo a ambigüidade e aumentando a clareza dos conceitos;

c) semi-formal - vocabulário em linguagem artificial formalmente definida;

d) rigorosamente formal - vocabulário com termos meticulosamente definidos, através de semântica formal, teoremas e provas de completude (completeness) e corretude (soundness).

Para Valente (1995, p. 79), o papel de uma ontologia formal na representação do conhecimento é servir de base e complementar a descrição dos conceitos em linguagem natural, funcionando como um meio para verificar a coerência e a completude dessas descrições, ao invés de substituí-las.

Apesar dos termos “Ontologia” e "Modelo Conceitual" serem muitas vezes empregados para nomear o mesmo tipo de representação do mundo, alguns autores (GRUBER, 1992; WELTY e GUARINO, 2001; GUIZZARDI et al., 2002) salientam as diferenças entre essas duas noções. Gruber (1992) sugere que um modelo conceitual de uma base de dados oferece uma descrição lógica dos dados compartilhados, definindo as relações existentes entre os dados, que são associados aos fatos atômicos, enquanto uma ontologia define os termos que representam o conhecimento, e é composta por sentenças lógicas formadas por variáveis quantificadas existencialmente e universalmente. Welty e Guarino (2001) sugerem uma diferenciação entre esses termos, considerando um modelo conceitual como sendo uma implementação de uma determinada ontologia, implementação essa que satisfaz os requisitos de Engenharia da aplicação. O projeto de uma ontologia é independente das considerações técnicas da aplicação, e tem como único objetivo especificar a conceitualização do mundo. Segundo Guizzardi et al. (2002), um modelo conceitual deve identificar, analisar e descrever os conceitos e restrições de um domínio, através de uma linguagem de modelagem baseada em um conjunto pequeno de metaconceitos, por exemplo classes, relações e atributos. Ontologias, por outro lado, devem capturar as entidades do domínio e representá-las por meio de uma linguagem ontológica baseada em categorias ontológicas que são independentes de domínio. Essas categorias têm suas raízes em princípios filosóficos, tais como “quais são os tipos de coisas existentes” e “quais são os tipos de relações entre elas”, formando assim uma ontologia de alto nível, a partir da qual a ontologia propriamente dita deve ser desenvolvida. 
Taxonomias, que são classificações de conceitos, formam a parte central da maioria dos modelos conceituais e das ontologias. Taxonomias bem estruturadas ajudam a ordenar os elementos do modelo e são úteis na apresentação de visões limitadas do modelo para a interpretação humana. Welty e Guarino (2001) propõem uma formalização de taxonomias que consiste na adaptação das noções da prática filosófica de ontologia formal para os sistemas de informação. Essas noções - identidade, essência, unidade e dependência oferecem uma estrutura lógica sólida para a análise de taxonomias. O objetivo dessa análise é ajudar a explicitar o significado dos conceitos envolvidos, melhorando o entendimento e reduzindo os custos de integração de sistemas.

\subsubsection{Utilização de Ontologias}

Segundo Uschold e Gruninger (1996), uma ontologia tem diversas formas de uso e podem ser agrupadas em três categorias segundo a sua utilização: comunicação, interoperabilidade e Engenharia de sistemas.

Ontologias podem ser utilizadas para melhorar a comunicação, pois facilitam o compartilhamento de conhecimento entre pessoas, organizações e sistemas de software, graças à redução de confusões conceituais e terminológicas, proporcionada pela unificação de conceitos.

Ontologias podem apoiar a interoperabilidade de sistemas, pois permitem a troca de informação entre sistemas que utilizam linguagens ou representações distintas. Nesse caso, uma ontologia funciona como uma interlingua entre os diversos sistemas, por meio da tradução de diferentes linguagens e representações. Os ambientes multiagentes com arquiteturas distintas, onde diferentes tipos de agentes precisam se comunicar para atingir seus objetivos são exemplos de casos nos quais uma ontologia pode ser necessária para a criação de um ambiente integrado para modelos distintos.

Em Engenharia de sistemas, as ontologias apóiam o projeto e o desenvolvimento dos mesmos, facilitando a fase de especificação, aumentando a confiabilidade (reliability) e promovendo a reusabilidade (reusability) de sistemas. Durante a especificação, ontologias podem apoiar o processo de identificação de requisitos e a compreensão dos relacionamentos entre os componentes do sistema. Servindo como uma base para a verificação manual do projeto (design) em relação à especificação original, ontologias podem aumentar a confiabilidade dos sistemas. Finalmente, por meio da criação de bibliotecas de ontologias, que podem ser reusadas e adaptadas para diferentes problemas ou domínios, as ontologias provêem a reusabilidade. 


\subsection{Metodologias para a Construção de Ontologias}

Diversas metodologias foram propostas para a construção de ontologias (CORCHO et al., 2003), entre elas a metodologia de Uschold e Gruninger (1996) e a Methontology, proposta por Fernandez-Lopez et al. (1997), detalhadas a seguir.

\subsubsection{Metodologia de Uschold e Gruninger (1996)}

A metodologia para a construção e avaliação de ontologias proposta por Uschold e Gruninger (1996) envolve três fases de desenvolvimento propriamente dito: (i) a identificação do objetivo e escopo, (ii) a construção e (iii) a avaliação da ontologia. Além disso, contempla duas fases de suporte ao desenvolvimento, que são executadas de forma concomitante com as demais fases, (iv) a definição de guias e (v) a documentação da ontologia. Estas cinco fases são descritas a seguir.

\section{i) Identificação do objetivo e do escopo da ontologia}

A função desta fase é esclarecer porque a ontologia será construída e como será utilizada. O escopo da ontologia é definido por meio das chamadas questões de competência. Essas questões descrevem os requerimentos (requirements) que devem ser atendidos pela ontologia, em linguagem natural e de forma interrogativa. A ontologia deve permitir a representação dessas questões e de suas respostas através de seus componentes, como conceitos e relacionamentos.

ii) Construção da ontologia

A função desta fase é construir a ontologia propriamente dita. É composta por três atividades:

- Captura da ontologia, durante a qual se esboça a conceitualização da ontologia. Contempla três passos: a identificação dos conceitos chave e dos relacionamentos existentes no domínio; a descrição desses conceitos e relacionamentos através de um texto não ambíguo; e a escolha dos termos para identificar cada conceito e relacionamento;

- Codificação da ontologia, durante a qual a conceitualização esboçada na atividade anterior é representada através de uma linguagem formal. Envolve três passos: a escolha das primitivas, ou meta-termos ${ }^{9}$, que serão utilizados para expressar os termos do domínio da ontologia; a escolha da linguagem formal

\footnotetext{
${ }^{9}$ Por exemplo: classes, entidades, relações.
} 
para representar a ontologia e a implementação da ontologia na linguagem escolhida;

- Integração com ontologias existentes, sendo que o objetivo dessa atividade é integrar parte de ontologias já existentes àquela que está sendo construída, através da adaptação e reuso de conceitos.

iii) Avaliação da ontologia

A função desta fase é verificar as características da ontologia, como a sua expressividade e consistência, por meio das questões de competência que descrevem o seu escopo. Nesta fase, as questões de competência que foram formuladas em linguagem natural são descritas em linguagem formal. Os elementos usados na formulação dessas questões de competência, tais como as classes e suas restrições, devem fazer parte da ontologia.

\section{iv) Definição de guias}

O objetivo desta fase é definir o conjunto de técnicas e métodos utilizados durante as demais fases, assim como indicar o relacionamento entre elas, tais como a ordem de execução e as entradas e saídas de cada fase. Alguns critérios para projetos de ontologias são sugeridos como guias:

- Manter a clareza da ontologia, minimizando as ambigüidades, usando exemplos para facilitar o entendimento e documentando as definições em linguagem natural;

- Buscar a coerência da ontologia, através da definição de axiomas logicamente consistentes e da documentação dos componentes em linguagem natural de forma precisa;

- Garantir a possibilidade de extensão da ontologia, oferecendo uma base conceitual para definição de novos termos.

v) Documentação da ontologia

Esta fase deve garantir que a construção da ontologia seja documentada adequadamente. A documentação deve incluir as principais premissas formuladas durante a fase de construção, tanto sobre os conceitos como sobre as primitivas, ou meta-conceitos, utilizados. 


\subsubsection{Methontology de Fernandez-Lopez et al. (1997)}

Methontology (FERNANDEZ-LOPEZ et al., 1997; FERNANDEZ-LOPEZ, 1999) é uma metodologia para a construção de ontologias desenvolvida pelo Laboratório de Inteligência Artificial da Universidade Politécnica de Madrid. Esta metodologia propõe um processo de desenvolvimento de ontologias composto por três categorias de atividades: atividades de gerenciamento, atividades de desenvolvimento e atividades de suporte.

i) Atividades de gerenciamento

Estas atividades descrevem a organização do projeto de construção da ontologia: o planejamento, a gestão e o controle de qualidade (quality assurance) do produto final.

Durante a atividade de planejamento devem ser identificadas as tarefas que serão executadas, a duração de cada uma, a seqüência em que serão efetuadas e os recursos envolvidos na sua execução. A gestão tem como objetivo garantir que a execução das tarefas acontecerá segundo o planejado, enquanto o controle de qualidade deve assegurar que a qualidade do produto final seja satisfatória.

ii) Atividades de desenvolvimento

Estas atividades descrevem as tarefas diretamente envolvidas na construção da ontologia: a especificação, a conceitualização, a formalização, a implementação e a manutenção da mesma.

O objetivo da atividade de especificação é definir o motivo pelo qual a ontologia está sendo construída e por quem será utilizada. Durante a atividade de conceitualização, o conhecimento do domínio deve ser estruturado em um modelo conceitual. No decorrer da atividade de formalização, este modelo conceitual será transformado em um modelo formal, que por sua vez será transcrito em uma linguagem formal durante a atividade de implementação. A ontologia será atualizada e corrigida no decorrer da atividade de manutenção.

De maneira geral, as atividades dessa categoria correspondem a duas fases da metodologia proposta por Uschold e Gruninger (1996): fase de identificação do objetivo e fase de construção da ontologia.

iii) $\quad$ Atividades de suporte ao desenvolvimento

Estas atividades apóiam as atividades do ciclo de desenvolvimento. São elas: a aquisição de conhecimento, a integração de ontologias, a avaliação, a documentação e a configuração do ambiente de desenvolvimento. 
O objetivo da atividade de aquisição de conhecimento é coletar o conhecimento sobre um domínio específico. A atividade de integração deve ser executada quando a construção da ontologia envolver a reutilização de ontologias existentes. Durante a atividade de avaliação, são efetuadas a verificação e a validação da ontologia construída, garantindo a sua exatidão (correctness) e a sua correspondência com o conhecimento sobre o domínio que deveria representar. A atividade de documentação envolve a confecção de uma descrição detalhada e exaustiva dos produtos gerados. Durante a atividade de configuração, devem ser registradas as versões dos produtos gerados, de forma a permitir o controle das alterações efetuadas no decorrer do projeto.

As atividades dessa categoria correspondem principalmente às fases de avaliação e de documentação da metodologia proposta por Uschold e Gruninger (1996).

\subsection{Linguagens para Implementação de Ontologias}

\subsubsection{Introdução}

Esta seção apresenta um panorama das linguagens que podem ser utilizadas na implementação de ontologias, e descreve de forma detalhada as características de uma destas linguagens, a Ontology Web Language - OWL (DEAN e SCHREIBER, 2004), que foi utilizada na implementação da Ontologia Funcional de Reputação.

Os três paradigmas de representação de conhecimento mais utilizados nas linguagens para implementação de ontologias são: o cálculo de predicados de primeira ordem, as linguagens baseadas em frames e em abordagem orientada a objetos, e as lógicas descritivas (SU e ILEBREKKE, 2002).

O cálculo de predicados de primeira ordem utiliza fatos, objetos e relações para modelar o mundo. Por exemplo, em cálculo de predicados, o fato representando que a reputação de João é boa poderia ser descrito através do predicado binário Reputação (João, Boa), onde João e Boa são as constantes que representam os objetos e o predicado Reputação representa a relação entre estes objetos.

Os frames e as linguagens orientadas a objetos utilizam como primitivas de modelagem objetos estruturados ${ }^{10}$, também chamados de frames, e suas propriedades, também chamadas de atributos. Um frame oferece o contexto para a modelagem de um determinado aspecto de um domínio. Neste caso, o fato descrevendo a reputação do João

\footnotetext{
${ }^{10}$ Semelhante a classes em orientação a objetos.
} 
poderia ser representado por meio do frame Reputação \{alvo: João; avaliação: Boa\}, onde João e Boa são os valores dos atributos alvo e avaliação, respectivamente.

Lógicas descritivas (Description Logics - DLs), também conhecidas como lógicas terminológicas, formam uma classe de linguagens de representação do conhecimento baseadas em fragmentos da Lógica de Primeira Ordem. Estas lógicas apresentam um alto grau de expressividade, permitindo tanto a representação do conhecimento como o raciocínio automático sobre esse conhecimento (FENSEL et al., 2000). As lógicas descritivas oferecem um conjunto de construtores que permitem a representação de conceitos e papéis. Os conceitos, que correspondem às classes, são interpretados como conjunto de objetos, enquanto os papéis, que correspondem às relações, são interpretados como relações binárias entre os objetos. Neste caso, o fato descrevendo a reputação do João poderia ser representado pela classe Pessoa, que representa o conjunto de objetos que são pessoas, como o João, a classe Valor Reputação, que representa o conjunto dos objetos que são os valores possíveis de uma reputação, como o objeto Boa, e pela relação Tem Reputação entre os objetos João e Boa.

Uma das principais características das lógicas descritivas é a ênfase dada à eficiência do processo de inferência. As principais formas de inferência em uma lógica descritiva são a subsunção de classes, que verifica se uma classe é subconjunto de uma outra através da comparação de suas definições, e a classificação de instâncias, que verifica se um objeto pertence a uma determinada classe.

Diversas linguagens, que seguem os paradigmas descritos acima, foram desenvolvidas para expressar formalmente as ontologias, tais como KIF (GENESERETH e FIKES, 1992), Ontolingua (FARQUHAR et al., 1997), LOOM (MACGREGOR, 1991) e mais recentemente DAML+OIL (HORROCKS, 2002) e OWL (DEAN e SCHREIBER, 2004). A seguir, é feita uma breve descrição de suas principais características.

\subsubsection{KIF}

KIF (Knowledge Interchange Format) (GENESERETH e FIKES, 1992) é uma linguagem com alto poder de expressividade, baseada em uma extensão do cálculo de predicados, e tem como principal objetivo facilitar a troca de conhecimento entre sistemas construídos em diferentes linguagens. Trata-se de uma das primeiras linguagens desenvolvidas para representação de conhecimento, e tem como principais características (i) a semântica declarativa, por meio da qual o significado das expressões pode ser compreendido sem a ajuda de um interpretador, (ii) a base lógica, permitindo expressão de 
sentenças em cálculo de predicados, (iii) a representação de meta-conhecimento, permitindo definir de forma explícita as decisões tomadas durante a representação do conhecimento.

\subsubsection{Ontolingua}

O termo Ontolingua (GRUBER, 1992) designa tanto a linguagem como o ambiente Ontolingua Server (descrito na seção 3.4.3), desenvolvidos pela Universidade de Stanford. A linguagem Ontolingua é baseada em KIF e em Frame Ontology (FO). A FO, construída como uma camada sobre KIF, permite que a ontologia seja especificada segundo o paradigma de frames, oferecendo primitivas como classe e instâncias.

Ontolingua permite a construção de ontologias de três formas distintas: usando o vocabulário de FO, empregando as expressões de KIF e utilizando uma combinação das duas anteriores. Uma ontologia desenvolvida com Ontolingua envolve a definição de relações, classes, funções, indivíduos (instâncias das classes) e axiomas (CORCHO e GÓMEZ-PEREZ, 2000).

\subsubsection{LOOM}

LOOM (MACGREGOR, 91) é uma linguagem de representação de conhecimento baseada em lógica descritiva e regras de produção. Inicialmente, foi desenvolvida para a construção de bases de conhecimento genéricas e sistemas especialistas, e não para a especificação de ontologias. Permite a representação de conceitos, taxonomias, relações, funções, axiomas e regras de produção. Provê também um mecanismo de raciocínio automático que permite classificar os conceitos da ontologia (criação automática de taxonomias a partir de definições dos conceitos), verificação de consistência e execução de regras de produção.

\subsubsection{OIL}

OIL (Ontology Inference Layer) (FENSEL et al., 2000) consiste em uma linguagem para representação de ontologias e em uma camada de inferência baseada na Web. Combina três aspectos: (i) a semântica formal e o raciocínio das lógicas descritivas; (ii) as primitivas de modelagem das linguagens baseadas em frames; (iii) os padrões sintáticos para notações das linguagens da Web, nomeadamente, XML (Exchange Markup Language) e RDF (Resource Description Framework). 
XML (BRAY et al., 2000) é um formato universal para documentos e dados na Web, proposto pelo W3C (World Wide Web Consortium) ${ }^{11}$. A principal contribuição do XML é prover uma sintaxe comum para os documentos Web. Esquemas XML (XML Schemas) definem a estrutura, as restrições e a semântica de documentos Web. RDF (KLYNE e CARROLL, 2004) também foi proposto pelo W3C e consiste em uma infraestrutura para codificar, trocar e reusar metadados, provendo um padrão de representação para documentos em XML. O modelo de dados de RDF envolve três tipos de objetos: (i) os recursos, que são as entidades disponíveis, (ii) as propriedades, que são os predicados que descrevem os recursos, e (iii) as sentenças (statements), que associam um valor para uma propriedade em um recurso. Esquemas RDF (RDF Schemas) provêem um conjunto de primitivas de modelagem tais como classe, recurso e propriedade, e uma maneira padrão de codificá-los em XML.

\subsubsection{DAML+OIL}

DAML+OIL (Darpa Agent Markup Language+Ontology Inference Layer) (HORROCKS, 2002) é uma linguagem para especificação de ontologias que explora os padrões existentes para a Web, nomeadamente, XML e RDF, aos quais adiciona o formalismo de uma lógica descritiva. É resultado da junção da linguagem DAML-ONT, desenvolvida como parte do programa americano US DARPA Agent Markup Language, e da linguagem OIL. DAML+OIL permite descrever a estrutura de um domínio em termos de classes e propriedades, adotando um enfoque orientado a objetos.

\subsubsection{OWL}

A linguagem OWL (Ontology Web Language) (DEAN e SCHREIBER, 2004) é descrita aqui em maiores detalhes, pois foi a escolhida para a implementação da Ontologia Funcional de Reputação ${ }^{12}$, devido a fatores tais como a expressividade por ela oferecida e a sua grande utilização pela comunidade acadêmica. A seguir, apresentam-se os principais aspectos desta linguagem.

\footnotetext{
${ }^{11}$ http://www.w3.org/.

${ }^{12}$ A escolha da linguagem de implementação da Ontologia Funcional de Reputação faz parte das atividades previstas pela metodologia de desenvolvimento utilizada. A seção 5.5 apresenta a justificativa da escolha de OWL.
} 


\subsubsection{Introdução}

OWL foi proposta pelo W3C e consiste em uma revisão da linguagem DAML+OIL. OWL explora os padrões existentes para a construção de páginas Web, e foi desenvolvida para ser utilizada no contexto da Web Semântica (Semantic Web) (BERNERS-LEE et al., 2001).

Web Semântica é uma futura extensão da Web atual, na qual a informação tem sentido explícito, através da representação semântica, o que facilita o processamento automático e integrado das informações existentes nestas páginas. A Web Semântica explorará as funcionalidades oferecidas pelos padrões sintáticos para notações das linguagens da Web, tais como XML e RDF. O XML oferece a definição de esquemas baseados em marcas (tags), o RDF provê uma abordagem flexível para a representação dos dados, baseada na definição de objetos e do relacionamento entre eles, enquanto os esquemas RDF descrevem as classes e propriedades dos objetos (ou recursos) RDF. A OWL amplia o vocabulário para descrição de classes e propriedades em RDF, oferecendo funcionalidades como relações entre classes, cardinalidade de relacionamento e características de propriedades.

OWL é composta por três sub-linguagens, quais sejam, OWL Lite, OWL DL e OWL Full, que oferecem níveis de expressividade distintos e incrementais. OWL Lite, que é sintaticamente mais simples e menos expressiva que as demais, foi desenvolvida para ser usada na representação de ontologias que consistem em uma hierarquia simples de classes e que requerem a utilização de restrições pouco complexas.

OWL DL é mais expressiva que OWL Lite, apresentando semântica e propriedades formais bem definidas, como a decidibilidade. É baseada em lógica descritiva e permite a verificação de consistência da ontologia através de algoritmos de inferência. Uma das características chave de ontologias descritas em OWL Lite e OWL DL é o fato de poderem ser processadas por mecanismos de raciocínio automático (reasoner).

OWL Full é a mais expressiva das três sub-linguagens, tendo sido projetada para permitir a construção de ontologias que necessitam de um alto grau de expressividade, em detrimento da garantia de decidibilidade e da completude computacionais, visto que essa linguagem não permite o raciocínio automático. Apesar de OWL DL e OWL Full usarem os mesmos construtores, existe uma importante diferença entre elas, já que OWL DL requer a separação de tipos, ou seja, uma classe não pode ser também um indivíduo ou 
propriedade, e vice-versa. Por esse motivo só é possível definir meta-classes (classes cujas instâncias são também classes) em OWL Full.

OWL Full pode se vista como uma extensão do RDF, enquanto OWL Lite e OWL DL são extensões de uma visão restrita do RDF (MCGUINNESS e HARMELEN, 2004). Assim, todo documento em OWL é também um documento em RDF e consiste em um conjunto de expressões em mark up language.

Uma ontologia em OWL contém classes, propriedades e instâncias de classes (SMITH et al., 2004). As classes são um mecanismo de abstração para agrupar elementos com características similares. Instâncias são os indivíduos que pertencem às classes. Propriedades são relacionamentos entre os indivíduos de duas classes, designadas de classe domínio (domain) e classe imagem (range). A definição das classes e das propriedades em OWL pode envolver primitivas de RDF e de esquemas RDF. Nestes casos, são utilizados os prefixos $r d f$ e $r d f s$ no nome do construtor. Por exemplo, o termo rdfs:subClassOf indica que o construtor subClassOf faz parte do vocabulário de esquema RDF, enquanto o termo owl:Class indica que o construtor Class é primitivo de OWL.

\subsubsection{Classes em OWL}

Em OWL todas as classes são subclasses da classe Thing e representam um conjunto de indivíduos. Uma classe é definida através de descrições de classe (class descriptions), que são combinadas em axiomas de classe (class axioms). As seguintes funcionalidades e respectivos construtores podem ser usados na descrição de uma classe ${ }^{13}$ :

- Subclasse (rdfs : subclassof), usado para criar hierarquia de classes;

- Equivalência (owl: equivalentclass), usado para definir que duas classes são equivalentes, ou seja, possuem as mesmas instâncias;

- Enumeração (owl:one0f), que permite definir uma classe por meio da enumeração exaustiva das instâncias que a formam ${ }^{14}$;

- Disjunção (owl:disjointWith), que define que duas classes não podem ter nenhuma instância comum ${ }^{15}$;

\footnotetext{
${ }^{13}$ A expressão que aparece entre parênteses após o nome da funcionalidade corresponde ao construtor associado à mesma, que pode pertencer originalmente ao RDF, aos esquemas RDF, ou ainda ser uma primitiva OWL.

${ }^{14}$ Funcionalidade restrita a OWL DL e OWL Full.

${ }^{15}$ Funcionalidade restrita a OWL DL e OWL Full.
} 
- União (owl: unionof), interseção (owl:intersectionof) e complemento de classe (owl:complementof), usados para definir uma classe por meio da combinação de outras classes ${ }^{16}$.

O fragmento abaixo descreve a classe Homem, que é equivalente à classe Pessoa_Sexo_Masculino, subclasse de Pessoa e disjunta da classe Mulher .

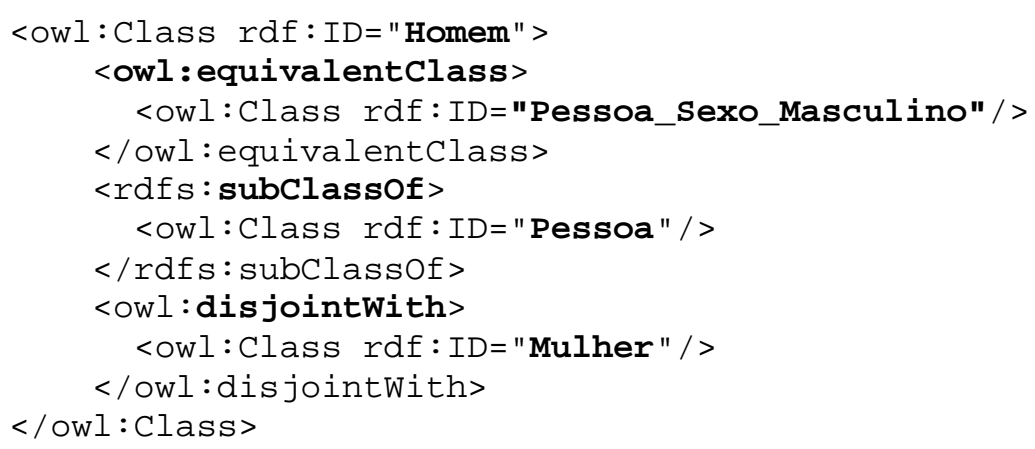

\subsubsection{Propriedades em OWL}

As propriedades em OWL representam o relacionamento entre dois indivíduos. As propriedades pertencem a duas categorias principais: propriedade de objeto (object properties) e propriedade de tipo de dado (datatype properties). As propriedades de objeto relacionam indivíduos a indivíduos. Por exemplo, o relacionamento entre duas instâncias da classe Pessoa.

As propriedades de tipo de dado relacionam indivíduos ao formato de dados, que podem ser tanto literais RDF como tipos de dados definidos de acordo com esquemas XML. Alguns exemplos de formatos de dados disponíveis são: string (xsd: string), número decimal (xsd:decimal), número inteiro (xsd:integer), data e hora (xsd: dateTime), constante booleana (xsd: boolean), mês do ano (xsd: gMonth).

As seguintes funcionalidades, e seus respectivos construtores, podem ser aplicados às propriedades:

- Sub-propriedade(rdfs: subPropertyof), que permite criar hierarquias de propriedades;

- Domínio (rdfs: domain), que limita os indivíduos aos quais a propriedade se aplica;

- Imagem (rdfs: range), que limita os indivíduos que a propriedade tem como valor;

\footnotetext{
${ }^{16}$ Funcionalidades restritas a OWL-DL e OWL-Full.
} 
- Equivalência ( $r$ dfs : equivalentProperty) define a equivalência entre duas propriedades;

- Propriedade inversa (owl : inver se0f) define que uma propriedade é o inverso de outra ${ }^{17}$;

- Propriedade transitiva (owl : transitiveProperty) define a transitividade de uma propriedade;

- Propriedade simétrica (owl:symmetricProperty) especifica que uma propriedade é igual a sua inversa $^{18}$;

- Propriedade funcional (owl:functionalProperty) especifica que a propriedade tem um único valor ${ }^{19}$;

- Propriedade funcional inversa (owl:inversefunctionalProperty) especifica que a propriedade inversa é funcional.

O fragmento abaixo apresenta um exemplo de utilização de propriedade de objeto em OWL. Este fragmento define a propriedade temmãe, que é sub-propriedade de temGenitor, tem a propriedade temFilho como inversa e a classe Pessoa como imagem.

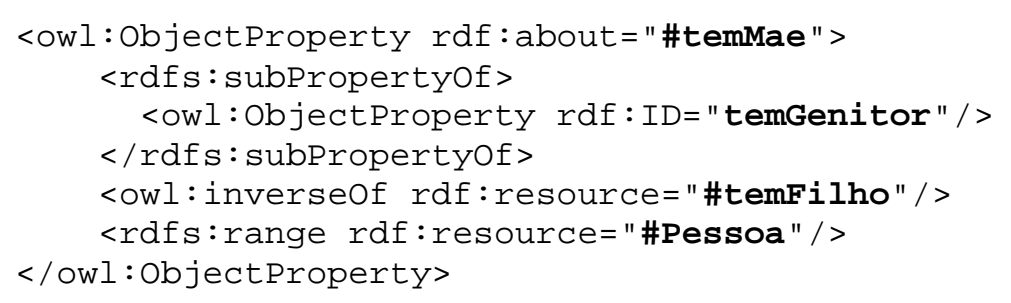

O fragmento abaixo apresenta um exemplo de utilização de propriedade de tipo de dado em OWL. Este fragmento define a propriedade temNome, que tem como imagem uma string.

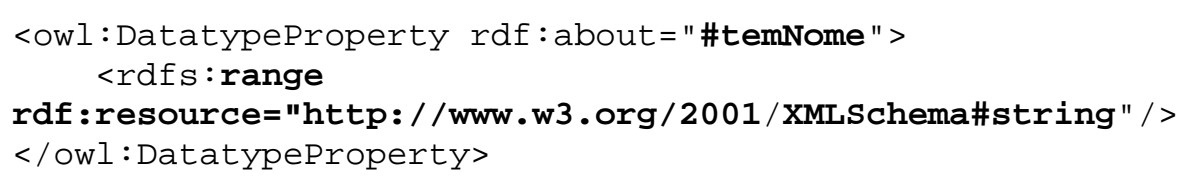

\subsubsection{Limitação de Propriedade em OWL}

Em OWL, a limitação de propriedade ${ }^{20}$ (property restriction) permite descrever uma classe por meio de restrições sobre propriedades que devem ser obedecidas por todos

\footnotetext{
${ }^{17}$ As propriedades éGenitorDe e éFilhoDe são exemplos de propriedades inversas.

${ }^{18}$ A propriedade éIrmãoDe é um exemplo de propriedade simétrica.

${ }^{19}$ A propriedade temDataNascimento é um exemplo de propriedade funcional.
} 
os indivíduos que pertencem à classe. Como o nome sugere, os limites de propriedade são usados para limitar os indivíduos que pertencem a uma classe. Essas limitações, que se aplicam à propriedade no contexto da classe sendo descrita (os indivíduos da classe são o domínio da propriedade), podem ser de dois tipos: restrição de valor (value constraint) e restrição de cardinalidade (cardinality constraint).

Tanto uma restrição de valor como uma restrição de cardinalidade descrevem um conjunto anônimo que contém os indivíduos que satisfazem a restrição. Este conjunto pode ser considerado como sendo uma classe anônima. Qualquer indivíduo membro desta classe anônima deve satisfazer a restrição que a descreve. Quando se descreve uma classe por meio de uma restrição, o que se faz efetivamente é descrever uma superclasse anônima daquela classe.

As seguintes funcionalidades, e respectivos construtores, podem ser usados para definir restrições de valor em uma propriedade durante a descrição de uma classe, o que restringe a imagem (range) da propriedade no contexto da classe:

- Restrição existencial (owl : someValuesFrom)

É a restrição mais comum em OWL e especifica a existência de pelo menos um relacionamento, através de dada propriedade, entre os indivíduos da classe sendo descrita (domínio da propriedade) e os indivíduos da classe imagem da propriedade.

Por exemplo, o fragmento abaixo descreve a classe ProfessorPesquisador, definida como sendo uma subclasse da classe Pessoa e da classe anônima que contém os indivíduos que tem algum aluno da classe AlunoRegular.

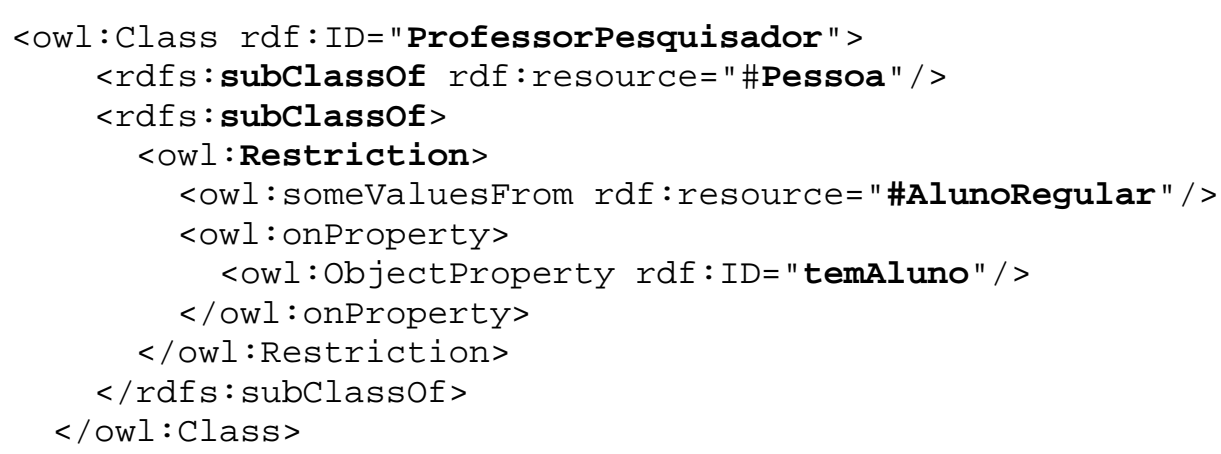

Essa restrição existencial não implica que todos os indivíduos da classe ProfessorPesquisador tem apenas alunos regulares, mas apenas que pelo menos um dos alunos é aluno regular.

\footnotetext{
${ }^{20}$ A palavra limitação foi usada como tradução de restriction enquanto a palavra restrição foi utilizada como tradução de constraint.
} 
- Restrição universal (owl : allValuesFrom)

Especifica que, através de uma dada propriedade, todos os relacionamentos existentes entre os indivíduos da classe sendo definida os associam aos indivíduos da classe imagem da propriedade.

O fragmento abaixo apresenta como exemplo a descrição da classe ProfessorPesquisador, definida como sendo uma subclasse da classe Pessoa e da classe anônima contendo os indivíduos que tem apenas alunos regulares.

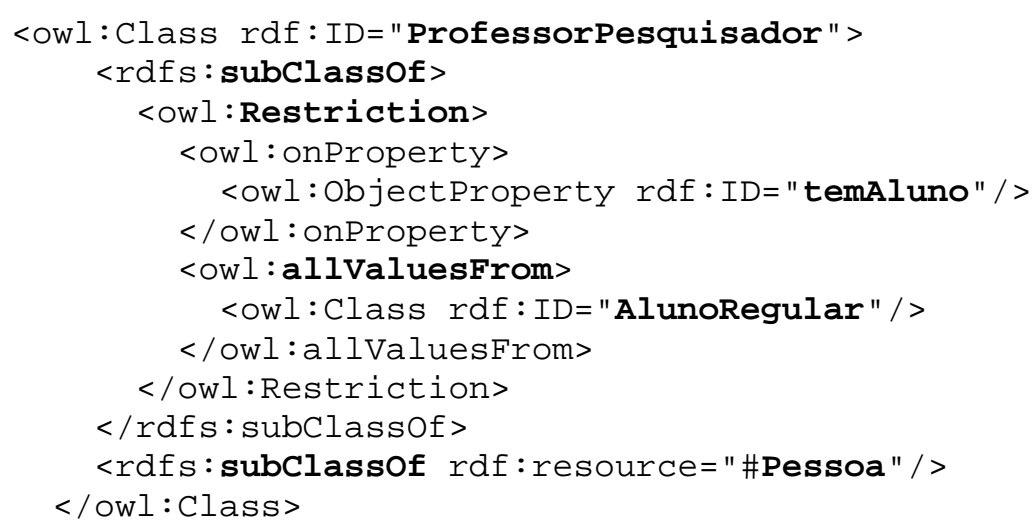

Ao contrário da restrição existencial, a restrição universal não garante a existência de um relacionamento sobre a propriedade temAluno para todos os indivíduos da classe ProfessorPesquisador. Ela apenas garante que, se tal relacionamento existe, então deve ser com indivíduos da classe AlunoRegular.

- Restrição de indivíduo (owl : hasValue)

Especifica que, através de uma dada propriedade, pelo menos um dos relacionamentos dos indivíduos da classe sendo definida é com um determinado indivíduo ${ }^{21}$.

As seguintes funcionalidades restringem a cardinalidade de uma propriedade no contexto da descrição de uma determinada classe. Cabe ressaltar que em OWL Lite apenas os números 0 e 1 podem ser utilizados na restrição de cardinalidade.

- Cardinalidade mínima (owl:minCardinality) define o número mínimo de relacionamentos, através de dada propriedade, que um indivíduo deve ter;

- Cardinalidade máxima (owl:maxCardinality) define o número máximo de relacionamentos, através de dada propriedade, que um indivíduo pode ter;

\footnotetext{
${ }^{21}$ Funcionalidade restrita a OWL DL e OWL Full.
} 
- Cardinalidade (owl:cardinality) define o número exato de relacionamentos, através de dada propriedade, que um indivíduo deve ter.

Por exemplo, o fragmento abaixo descreve a classe Mãe como sendo uma subclasse de Mulher e da classe anônima que contém os indivíduos que tem no mínimo um filho.

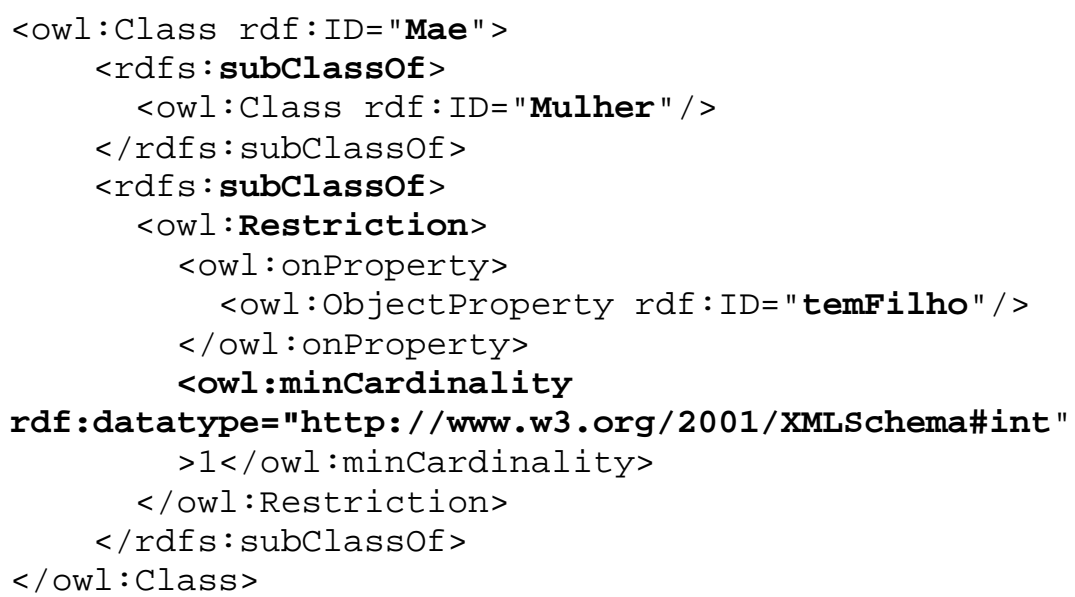

\subsection{Ambientes para a Edição e Construção de Ontologias}

\subsubsection{Introdução}

Diversos ambientes foram criados para apoiar a edição e a construção de ontologias (CORCHO et al., 2003). Estes ambientes normalmente oferecem uma interface gráfica que permite que o usuário crie e edite as ontologias sem usar diretamente a linguagem de implementação da ontologia. Além disso, oferecem conexão com sistemas de raciocínio automático, ou motores de inferência, através dos quais pode-se verificar a consistência das ontologias e executar a subsunção de suas classes. O fato de algumas das linguagens para implementação de ontologias terem uma sintaxe complexa, como OWL e DAML-OIL, dificulta a tarefa de implementação manual de ontologias. Nestes casos o uso de editores de ontologias com interface gráfica e mecanismos de validação da linguagem é essencial para facilitar a tarefa de codificação da ontologia.

Exemplos desses ambientes são OilEd (HORROCKS et al., 2001), Servidor Ontolingua (FARQUHAR et al., 1997), WebODE (ARPIREZ et al., 2001), e Protégé (GENNARI et al., 2003). O desenvolvimento da Ontologia Funcional de Reputação ${ }^{22}$

\footnotetext{
${ }^{22}$ A escolha do ambiente de desenvolvimento da Ontologia Funcional de Reputação faz parte das atividades previstas pela metodologia de desenvolvimento utilizada. A seção 5.5 apresenta a justificativa da escolha do Protégé.
} 
envolveu este último. Por este motivo, esta seção descreve o Protégé de forma mais detalhada que os demais ambientes.

\subsubsection{OilEd}

OilEd (HORROCKS et al., 2001) é um editor de ontologias para as linguagens OIL e DAML-OIL, desenvolvido pela Universidade de Manchester e pela Universidade Livre de Amsterdã. Integra o motor de inferência FaCT (HORROCKS, 1999), permitindo a verificação de consistência da ontologia, bem como a classificação automática da taxonomia. No OilEd é possível importar ontologias implementadas em RDF e OIL e exportar ontologias em RDF, OIL e DAML-OIL.

\subsubsection{Ontolingua}

O servidor Ontolingua (FARQUHAR et al., 1997) consiste em um conjunto de ferramentas de apoio para a construção de ontologias na linguagem homônima, de forma compartilhada entre grupos distintos. Foi desenvolvido pelo Laboratório de Sistemas de Conhecimento (Knowledge Systems Laboratory) da Universidade de Stanford e oferece funcionalidades tais como editor para criação de ontologias, acesso a bibliotecas de ontologias e tradutores de linguagens (Prolog, LOOM, etc), que podem ser usadas de forma local ou remota.

\subsubsection{WebODE}

WebODE (ARPIREZ et al., 2001), desenvolvido pelo Laboratório de Inteligência Artificial da Universidade Técnica de Madri (UPM), é um ambiente integrado para a construção de ontologias baseado em tecnologia Web. O WebODE permite manipular as representações intermediárias de uma ontologia realizadas de acordo com a metodologia Methontology (ver seção 3.2.2), apoiando parte das atividades envolvidas no ciclo de desenvolvimento de uma ontologia segundo esta metodologia. Os principais serviços oferecidos por este ambiente são: editor de ontologia, construtor de axiomas, motor de inferência baseado em OKBC (The Open Knowledge Base Connectivity protocol) e serviço de interoperabilidade com outros ambientes de desenvolvimento de ontologias. 


\subsubsection{Protégé}

Protégé (GENNARI et al., 2003) é um ambiente integrado para a edição de ontologias e a construção de sistemas baseados em conhecimento (knowledge-based systems), desenvolvido pelo Grupo Médico de Informática da Universidade de Stanford (Stanford Medical Informatics group - SMI). Apesar do desenvolvimento do Protégé ter sido historicamente voltado para aplicações biomédicas, o ambiente é independente de domínio e tem sido utilizado em outras áreas de aplicação. O Protégé é baseado em um meta-modelo que pode ser comparado com sistemas de orientação a objeto, podendo representar ontologias que consistem em classes, propriedades (slots), características de propriedades (facets e constraints) e instâncias. Pode ser usado para carregar, editar e salvar ontologias em vários formatos, incluindo RDF, XML e UML.

O Protégé consiste em uma aplicação com código fonte aberto e arquitetura baseada em componentes, permitindo a extensão de suas funcionalidades básicas através do desenvolvimento de plug-ins. Por meio do Protégé OWL Plug-in ${ }^{23}$ (KNUBLAUCH et al., 2004), é possível utilizar o Protégé para a construção de ontologias em OWL. Tal plug-in fornece apoio às sub-linguagens OWL Lite e OWL DL, e a uma parte significativa de OWL Full. Como extensão do Protégé, o Protégé OWL Plug-in beneficia-se de ampla comunidade de usuários, de biblioteca de componentes reutilizáveis e de uma arquitetura flexível.

O ambiente Protégé oferece acesso, através de um botão da sua interface gráfica, a motores de inferência para Lógica Descritiva, tal como o RACER (HAARSLEV e MOLLER, 2003).

A figura 3.1 apresenta uma tela do Protégé com o OWL Plug-in contendo a descrição da classe Mãe.

\footnotetext{
${ }^{23}$ http://protege.stanford.edu/plugins/owl.
} 


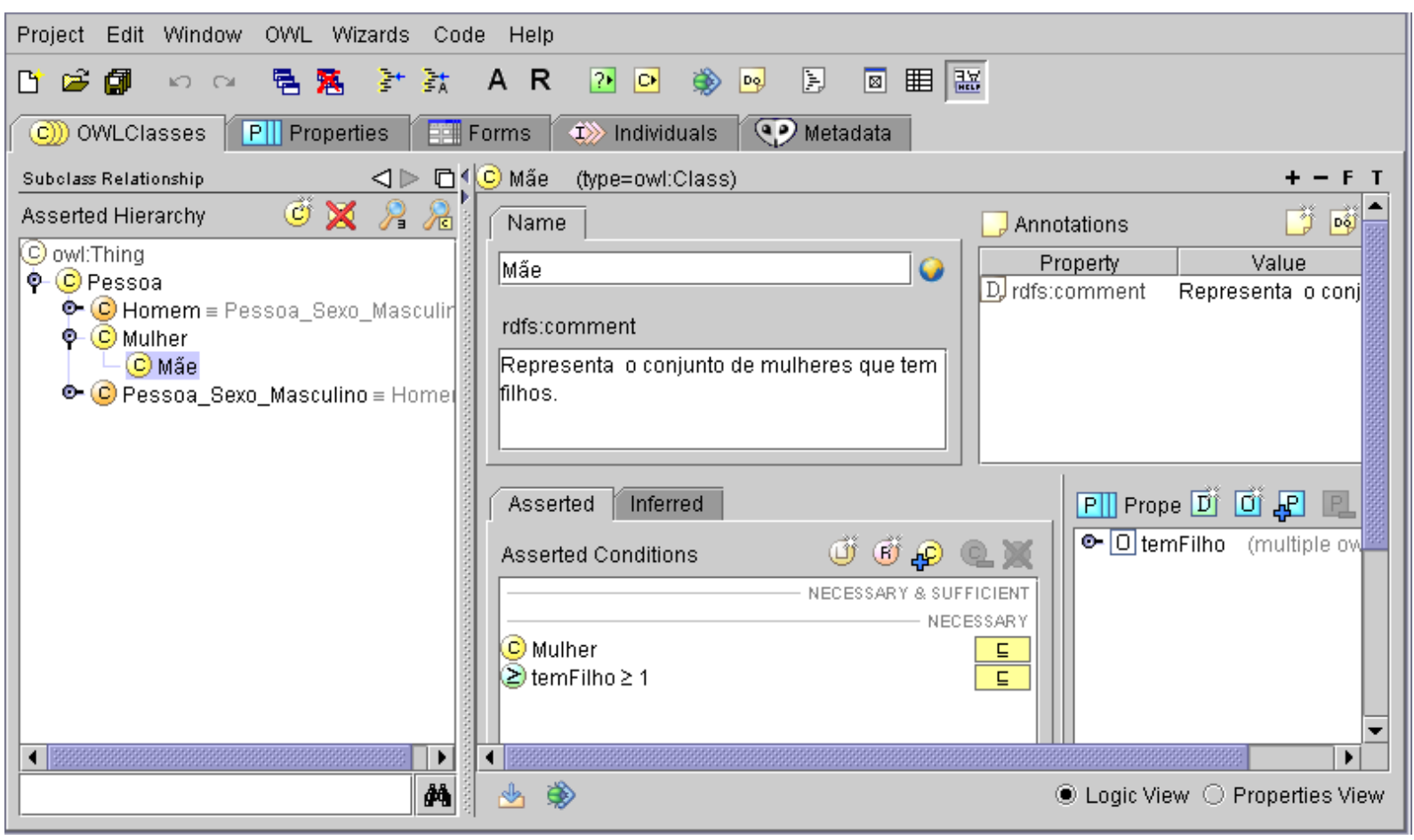

Figura 3.1: Janela do Protégé com OWL Plug-in contendo uma hierarquia de classes

\subsection{Ambientes para Raciocínio Automático com Ontologias}

\subsubsection{Introdução}

Durante a construção de uma ontologia, os ambientes para raciocínio automático oferecem dois serviços principais, a verificação de consistência e a determinação da subsunção de classes. O primeiro garante que a descrição de uma classe não contém inconsistências, podendo, portanto, ter instâncias. Por exemplo, a descrição da classe Genitor como sendo o conjunto de indivíduos que pertencem à classe Mãe e à classe Pessoa_Sexo_Masculino é uma descrição inconsistente, visto que Mãe e Pessoa_Sexo_Masculino são classes disjuntas.

O teste de subsunção, também chamado de classificação da ontologia, consiste em verificar se a descrição de uma classe determina a existência de um relacionamento de superclasse / subclasse com as demais classes da ontologia. Por meio da realização do teste de subsunção em todas as classes da ontologia é possível criar uma nova hierarquia de classes, chamada de hierarquia inferida, complementar à hierarquia explicitamente desenvolvida.

Diversos ambientes permitem o raciocínio automático com ontologias, como FaCT (HORROCKS, 1999), Pellet (PARSIA e SIRIN, 2004) e RACER (HAARSLEV e 
MOLLER, 2003). Este último foi utilizado no desenvolvimento da Ontologia Funcional de Reputação ${ }^{24}$ e por isso esta seção o descreve de forma mais detalhada.

\subsubsection{FaCT}

FaCT (Fast Classification of Terminologies) (HORROCKS, 1999) é um sistema de raciocínio automático para ontologias escritas em Lógica Descritiva que permite executar tanto a classificação de ontologias como a verificação de consistência de classes. Contudo, não oferece serviços de raciocínio com instâncias. iFaCT é uma extensão de FaCT que permite o raciocínio com propriedades inversas.

\subsubsection{Pellet}

Pellet (PARSIA e SIRIN, 2004) é um motor de inferência desenvolvido para raciocinar sobre ontologias escritas em OWL. Ao contrário de FaCT e de RACER, que podem ser usados com várias lógicas descritivas, o objetivo de Pellet é ser usado exclusivamente com OWL. Dessa forma, pode explorar as funcionalidades da OWL, oferecendo raciocínio sobre tipo de dados (datatype) e consultas sobre instâncias. Outra funcionalidade oferecida é a reparação de ontologias, que transforma, através de heurísticas, uma ontologia original em OWL Full, que não permite raciocínio automático, em outra ontologia em OWL DL, que possibilita tal tipo de raciocínio.

\subsubsection{RACER}

RACER - Renamed Abox and Concept Expression Reasoner - (HAARSLEV e MOLLER, 2003, 2004) é um motor de inferência para lógica descritiva desenvolvido na Universidade de Hamburgo (Alemanha), em conjunto com a Universidade de Concórdia (Canadá) e Universidade de Ciências Aplicadas de Weddel (Alemanha). As principais funcionalidades oferecidas pelo RACER são a verificação de consistência de classes e a subsunção de classes, incorporando técnicas de otimização que permitem o manuseio de grandes ontologias. Além disso, manuseia instâncias de classes, provendo teste de instância (verifica se dada instância pertence a uma classe) e computação de tipos diretos (identifica a classe mais específica que pode ser associada a uma dada instância).

\footnotetext{
${ }^{24}$ A escolha do ambiente para raciocínio automático com ontologias faz parte das atividades previstas pela metodologia de desenvolvimento utilizada. A seção 5.5 apresenta a justificativa da escolha do RACER.
} 
É baseado em algoritmos de inferência que são completos (complete) e corretos (sound) para o raciocínio com classes, ou seja, encontram a solução se esta existe e garantem que a solução encontrada é correta. Contudo, o raciocínio com instâncias não é completo, causando resultados inesperados quando instâncias são utilizadas na definição de classes, por exemplo por meio do construtor owl:hasValue (descrito na seção 3.3.2.3) (HORRIDGE, 2004, p.95).

RACER assume duas premissas lógicas importantes: (i) a premissa de nome único (unique name assumption), de acordo com a qual duas instâncias com nomes distintos são consideradas objetos distintos, e (ii) a premissa de mundo aberto (open world assumption), segundo a qual o que não pode ser provado como verdadeiro não é considerado falso e sim desconhecido (nil).

Além de oferecer um ambiente gráfico específico, o RICE (Racer Interactive Client Environment), RACER pode ser invocado de forma automática por vários ambientes de desenvolvimento de ontologias, tais como OilEd e Protégé. A sua utilização via Protégé é feita por meio um botão da janela principal do Protégé, que permite verificar a consistência e subsumir a ontologia sendo editada.

Algumas das funcionalidades adicionais do RACER são:

- Acessar ontologias escritas em DAML-OIL e OWL, a partir de arquivos locais ou servidores Web remotos;

- Implementar a interface especificada pelo Grupo de Implementação de Lógica Descritiva (DIG - Description Logic Implementation Group) para o acesso a sistemas de inferência para lógicas descritivas (BECHHOFER et al., 2003);

- Implementar uma interface baseada em TCP que pode ser acessada por meio de programas em Java ou $\mathrm{C}++$.

\subsection{Considerações Finais}

Este capítulo apresentou uma discussão sobre a utilização de ontologias como forma de representação do conhecimento e um panorama dos elementos envolvidos na sua construção: metodologias, linguagens, ambientes de desenvolvimento e motores de inferência.

A definição de ontologia adotada neste trabalho é aquela proposta por Uschold e Gruninger (1996), segundo a qual uma ontologia engloba uma visão específica do mundo 
relativa a um domínio, sendo concebida como um conjunto de conceitos e suas definições, bem como os relacionamentos entre eles.

A metodologia para a construção de ontologias proposta por Uschold e Gruninger (1996) e a Methontology, proposta por Fernandez-Lopez et al. (1997) foram as duas metodologias apresentadas. A primeira propõe três atividades principais para o desenvolvimento de uma ontologia - identificação de objetivo e escopo, construção e avaliação - enquanto a segunda é uma metodologia mais extensa, envolvendo, além das atividades de desenvolvimento, as atividades de gestão e de suporte.

Foram apresentadas várias linguagens para a implementação de ontologias, dentre elas Ontolingua (FARQUHAR et al., 1997), LOOM (MACGREGOR, 1991) e OWL (DEAN e SCHREIBER, 2004). Esta última foi descrita de forma mais detalhada que as demais, uma vez que foi a linguagem utilizada na implementação da Ontologia Funcional de Reputação.

Este capítulo apresentou ainda os diversos ambientes que podem ser usados para a edição e a construção de ontologias, tais como WebODE (ARPIREZ et al., 2001) e Protégé (GENNARI et al., 2003), e os mecanismos de raciocínio automático sobre elas, como Pellet (PARSIA e SIRIN, 2004) e RACER (HAARSLEV e MOLLER, 2003). As justificativas para a escolha dos elementos envolvidos na construção da ontologia - a metodologia de Uschold e Gruninger (1996), a linguagem OWL, o Protégé e o RACER são apresentados no capítulo 5.

O próximo capítulo apresenta a Ontologia Funcional do Direito (VALENTE, 1995), ontologia que define as categorias de conhecimento usadas como base da Ontologia Funcional de Reputação. 


\section{Ontologia Funcional do Direito}

Este capítulo apresenta a Ontologia Funcional do Direito proposta por Valente (1995), utilizada como base para o desenvolvimento da Ontologia Funcional de Reputação. O capítulo está organizado em 4 seções. Inicialmente, apresenta-se uma introdução sobre a Ontologia Funcional do Direito. Em seguida, a seção 4.2 descreve as categorias de conhecimento que compõem esta ontologia, enquanto a seção 4.3 apresenta uma visão integrada da mesma. Finalmente, a seção 4.4 apresenta algumas considerações sobre a utilização da Ontologia Funcional do Direito neste trabalho.

\subsection{Introdução}

A Ontologia Funcional do Direito, proposta por Valente (1995), apresenta uma estrutura parcimoniosa para representar e raciocinar com o conhecimento jurídico, por meio de uma abordagem baseada na modelagem do domínio do problema. A área de pesquisa na qual essa ontologia se insere é uma sub-área da IA, conhecida como IA \& Direito ( $A I \& L a w)$, cujo objetivo é o desenvolvimento de sistemas para resolver problemas jurídicos, através da representação do conhecimento jurídico e do raciocínio com esse conhecimento.

Essa ontologia foi desenvolvida a partir da literatura em Teoria do Direto e tem como base os textos dos principais teóricos desta área, principalmente Hart (1961) e Kelsen (1986, 2001). O papel desempenhado pela Teoria do Direito em IA \& Direito é prover as perspectivas e os pressupostos ontológicos necessários para a compreensão das questões inerentes a essa área de pesquisa.

A Ontologia Funcional do Direito é composta por um conjunto interconectado de categorias do conhecimento jurídico. A distinção entre estas categorias é dada pela perspectiva funcional, segundo a qual o sistema jurídico existe para cumprir uma certa função, a fim de alcançar objetivos sociais (VALENTE, 1995, p. 3). O sistema jurídico é visto como uma entidade dotada de uma certa estrutura interna e que age em um ambiente determinado, com o intuito de atingir metas sociais específicas. Valente (1995) salienta que o sistema jurídico é caracterizado por sua reação ao comportamento dos agentes sociais, na forma de punição ou compensação, tendo como resultado a regulação do comportamento 
social. Essa interpretação do sistema jurídico pressupõe uma forma de raciocínio que, partindo de um determinado comportamento social, é capaz de especificar as conseqüências legais desse comportamento.

A figura 4.1 ilustra o relacionamento do sistema jurídico com a sociedade.

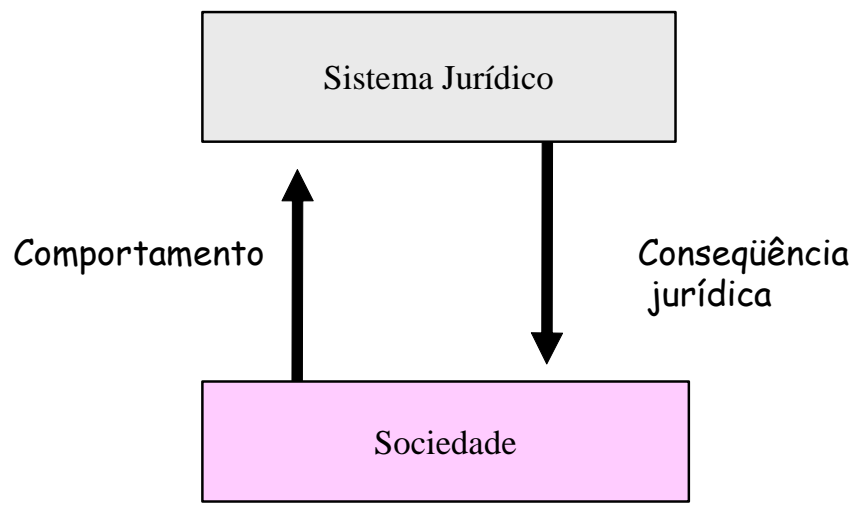

Figura 4.1: Relacionamento entre o Sistema Jurídico e a Sociedade (VALENTE, 1995, p.49)

A Ontologia Funcional do Direito foi descrita em Ontolingua (ver seção 3.3.3) e constitui a base para a representação do conhecimento da arquitetura ON-LINE. Tal arquitetura foi desenvolvida para armazenar e recuperar informações jurídicas, além de permitir o raciocínio com o conhecimento jurídico.

\subsection{Categorias de Conhecimento da Ontologia Funcional do Direito}

As categorias de conhecimento propostas pela Ontologia Funcional do Direito oferecem um critério funcional de classificação dos diversos componentes que fazem parte do sistema jurídico: Conhecimento Normativo (Normative Knowledge), Conhecimento Reativo (Reactive Knowledge), Conhecimento de Responsabilidade (Responsibility Knowledge), Conhecimento do Mundo (World Knowledge), Conhecimento Criativo (Creative Knowledge) e Conhecimento Meta-Jurídico (Meta-legal Knowledge). Além disso, a ontologia inclui uma sétima categoria, que não faz parte do sistema jurídico, o Conhecimento de Senso Comum (Common Sense Knowledge).

O Conhecimento Normativo é a categoria mais típica do conhecimento jurídico e tem duas funções distintas: prescrever o comportamento dos agentes e definir padrões de comparação com a realidade social. 
O Conhecimento Reativo especifica quais são as reações legais que devem ser associadas ao comportamento dos agentes. Normalmente, uma reação é uma sanção ou punição, mas pode ser também uma recompensa ou premiação em determinados casos.

O Conhecimento de Responsabilidade é um conhecimento intermediário entre o Conhecimento Normativo e o Conhecimento Reativo, dado que uma reação só pode ocorrer se o agente responsável for identificado como tal. Este conhecimento possibilita confirmar ou limitar a responsabilidade de um agente em uma dada situação, estabelecendo a ligação entre a violação de uma norma e o agente considerado responsável por esta violação.

O Conhecimento Criativo é o instrumento pelo qual se criam novas instituições normativas dentro do sistema jurídico.

O Conhecimento Meta-Jurídico define o meta-conhecimento do sistema jurídico, apresentando duas funções básicas, quais sejam, a implementação da dinâmica do sistema jurídico e a instituição dos mecanismos de resolução de conflitos entre as categorias do conhecimento jurídico, principalmente os conflitos gerados na aplicação das normas.

O Conhecimento do Mundo é uma interface entre o mundo legal e mundo real. Seu papel é definir um modelo do mundo real que possa ser usado como base para expressar os demais conhecimentos do sistema jurídico.

O Conhecimento de Senso Comum representa o mundo real, expressando o conhecimento geral que todas as pessoas possuem sobre o mundo do qual fazem parte.

A seguir, são descritas as principais categorias desta ontologia: o Conhecimento de Senso Comum, o Conhecimento do Mundo, o Conhecimento Normativo, o Conhecimento de Responsabilidade e o Conhecimento Reativo.

\subsubsection{Conhecimento de Senso Comum}

O Conhecimento de Senso Comum, também chamado de consenso de realidade (consensus reality), especifica o conhecimento geral que todas as pessoas possuem. Essa categoria de conhecimento inclui tanto os conceitos associados às entidades relevantes para o sistema jurídico como os conceitos genéricos de tempo e espaço.

As entidades relevantes para o sistema jurídico fazem parte da subcategoria Elemento Individuo (individual thing), composta por duas hierarquias de conceitos, Agente (agent) e Não Agente (non agent). O conceito Agente representa as coisas e pessoas que podem agir por si mesmo e assim produzir alterações no estado do mundo. São considerados agentes os conceitos Pessoa (person) e Organização (organisation). O 
conceito Não Agente representa os elementos que não podem ser responsabilizados juridicamente, mesmo quando são capazes de agir. São considerados não agentes os conceitos Ser Não Racional (non rational being) e Objeto (object).

A figura 4.2 apresenta a hierarquia de conceitos do Conhecimento de Senso Comum.

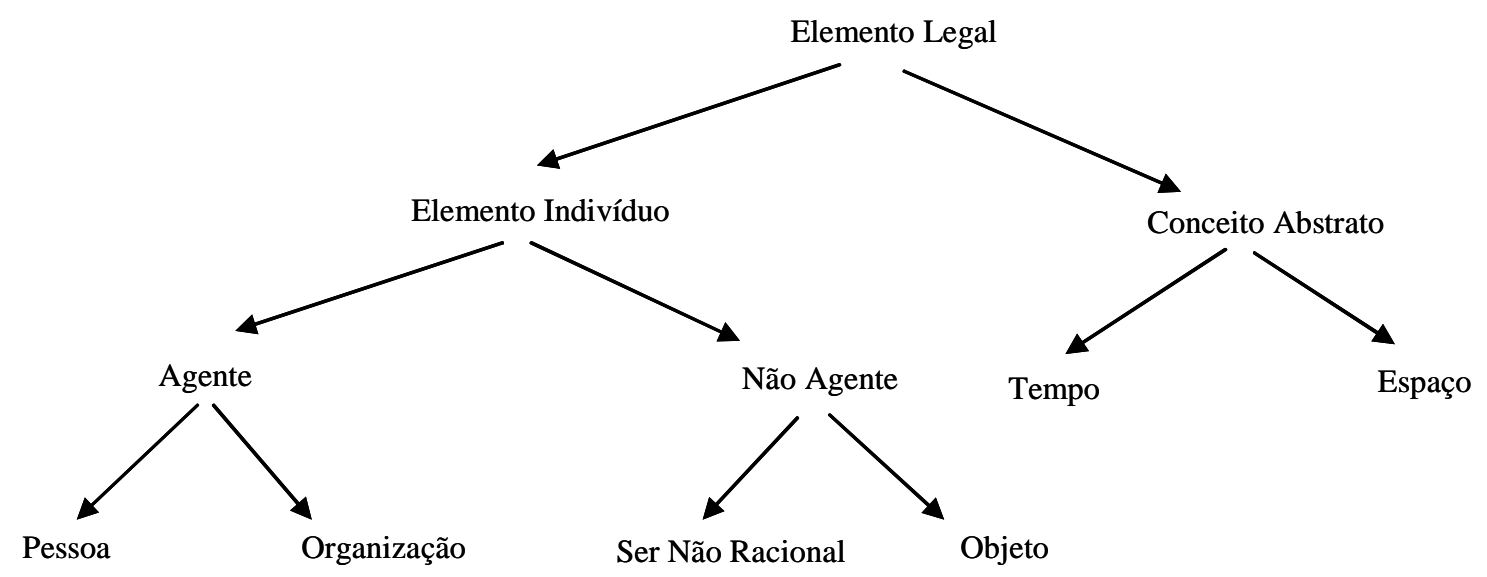

Figura 4.2: Hierarquia de conceitos do Conhecimento de Senso Comum, inspirado em ( VALENTE, 1995, p. 196)

\subsubsection{Conhecimento do Mundo}

A categoria Conhecimento do Mundo compreende o conhecimento do mundo sobre o qual se aplicam as normas jurídicas e especifica o modelo do mundo que o sistema jurídico procura regular através da imposição de normas. Esse mundo é, de fato, uma parte da sociedade, vista sob uma determinada perspectiva (VALENTE, 1995, p. 122).

Esta categoria desempenha o papel de interface entre o mundo real e o mundo jurídico, definindo um modelo do mundo real que possa ser usado como base para expressar, por um lado, as categorias típicas do sistema jurídico, tais como o Conhecimento Normativo e o Conhecimento de Responsabilidade e, por outro lado, os conceitos advindos do Conhecimento de Senso Comum. Assim, esse conhecimento descreve, de forma abstrata, as situações e os comportamentos que podem ocorrer no mundo real, especificando as possibilidades da realidade sem, contudo, especificar as diferenças entre a situação ideal e a situação real. Essa descrição é feita por meio de conceitos que representam as entidades e os relacionamentos existentes no mundo real, os quais são utilizados como ponto de partida para a definição das relações e conceitos do Conhecimento de Senso Comum. 
Os seis conceitos que compõem esse conhecimento são: Conceito Jurídico (legal concept), Relação Jurídica (legal relation), Caso (case), Caso Genérico (generic case), Circunstância (circumstance) e Condição (condition). Os dois primeiros fornecem um arcabouço que encapsula tanto os elementos do senso comum quanto o relacionamento existente entre eles. Assim, um conceito jurídico define a classe de coisas, tanto concretas como abstratas, que existem no mundo, enquanto uma relação jurídica é uma relação entre as instâncias desses conceitos.

Um Caso é uma descrição do comportamento de indivíduos em um conjunto de circunstâncias, enquanto um Caso Genérico é um padrão que descreve um conjunto de casos. Uma Circunstância é uma descrição da situação na qual o caso ocorreu e uma Condição é uma descrição genérica de circunstâncias similares.

Por exemplo, considere-se uma situação onde um motorista provoca um atropelamento e não socorre a vítima, fugindo do local do acidente. As circunstâncias poderiam ser descritas da seguinte forma: um motorista dirige em alta velocidade em local de velocidade controlada e não respeita a faixa de pedestres. Já a condição poderia ser descrita da seguinte forma: um motorista infringe regras de trânsito. O caso poderia ser descrito como: um motorista atropela um aluno na saída da escola e foge do local do acidente. Finalmente, o caso genérico poderia ter a seguinte descrição: atropelamento com fuga do local do acidente.

\subsubsection{Conhecimento Normativo}

Segundo a literatura da Teoria do Direito (HART, 1961), o Conhecimento Normativo tem duas funções claramente relacionadas: prescrever o comportamento e definir um padrão de comparação para a realidade social. A ontologia adota a visão segundo a qual a definição de um padrão de comparação é a principal característica do conhecimento normativo, sendo a prescrição do comportamento um dos efeitos da definição do padrão.

O conceito de norma usado na ontologia é derivado do trabalho de Kelsen (1986) e considera que uma norma expressa uma idealização, um mundo ideal, que pode ser obedecida ou violada. Uma norma é obedecida, ou observada, quando o comportamento do mundo real não conflita com a sua especificação no mundo ideal. Caso contrário, a norma é violada. A aplicação de uma norma consiste na verificação ou comparação do mundo real com o mundo ideal definido na norma, classificando a realidade como aderente 
ou não a essa norma. Essa classificação é denominada de status normativo do comportamento, de acordo com uma determinada norma.

A Ontologia Funcional do Direito adota a distinção entre norma primária e norma secundária proposta por Hart (1961). Normas primárias são aquelas relativas ao comportamento dos indivíduos, enquanto normas secundárias são aquelas que especificam a forma pela qual as normas primárias são criadas, eliminadas e alteradas. Nessa ontologia, a noção de norma primária está incorporada ao Conhecimento Normativo, e a noção de norma secundária está incorporada ao Conhecimento Meta-Jurídico.

Os principais conceitos que compõem o Conhecimento Normativo são Norma Primária (primary norm) e Status Normativo (normative status). As normas primárias são entidades que classificam o comportamento de um agente como permitido ou não permitido. Essa classificação, que é o status normativo de um comportamento em relação a uma norma, assume os valores de Permitido (allowed), Não Permitido (disallowed) e Neutro (silent), caso no qual uma determinada norma não pode ser usada para classificar o comportamento. Segundo essa definição, normas diferentes podem gerar status normativos distintos para o mesmo comportamento. Neste caso, é função do Conhecimento MetaJurídico resolver o conflito entre as normas primárias, decidindo qual status normativo deve prevalecer.

Retomando exemplo do atropelamento citado na seção 4.2.2, a norma primária a ser aplicada ao caso poderia ser: "é proibido abandonar o local do acidente sem prestar socorro”.

A tabela 4.1 ilustra a aplicação de normas primárias, e seus respectivos status normativos, para cinco comportamentos distintos. Além disso, tal tabela mostra um exemplo onde o mesmo comportamento, “João fuma na Sala B5”, pode gerar status normativos distintos: “não permitido” e “neutro”.

Tabela 4.1: Normas primárias, comportamentos e status normativos (VALENTE, 1995, p. 95)

\begin{tabular}{|c|l|l|}
\hline Norma Primária & \multicolumn{1}{|c|}{ Comportamento } & \multicolumn{1}{|c|}{ Status Normativo } \\
\hline \multirow{2}{*}{$\begin{array}{c}\text { É proibido fumar na sala de } \\
\text { aula }\end{array}$} & João fuma na Sala B5 & Não permitido \\
\cline { 2 - 3 } & João Fuma no pátio & Neutro \\
\hline $\begin{array}{c}\text { É permitido fumar na entrada } \\
\text { do prédio da Engenharia } \\
\text { Elétrica }\end{array}$ & João fuma na Sala B5 & Neutro \\
\cline { 2 - 3 } & $\begin{array}{l}\text { João fuma na lanchonete da Poli, que } \\
\text { está na entrada do prédio }\end{array}$ & Permitido \\
\hline $\begin{array}{c}\text { É obrigatório ficar em silêncio } \\
\text { na biblioteca }\end{array}$ & João conversa na biblioteca & Não permitido \\
\hline
\end{tabular}




\begin{tabular}{|l|l|l|}
\hline Norma Primária & \multicolumn{1}{|c|}{ Comportamento } & \multicolumn{1}{c|}{ Status Normativo } \\
\hline & João conversa na lanchonete da Poli & Neutro \\
\hline
\end{tabular}

\subsubsection{Conhecimento de Responsabilidade}

O Conhecimento de Responsabilidade tem como função atribuir ou limitar a responsabilidade de um agente em uma dada situação, estabelecendo uma ligação entre a violação de uma norma e o agente responsável pela violação. Esse conhecimento é uma categoria intermediária entre o Conhecimento Normativo e o Conhecimento Reativo, visto que a reação só pode ocorrer após a atribuição de responsabilidade pela violação da norma por um agente determinado.

A Restrição de Responsabilidade (responsibility restriction) e a Confirmação de Responsabilidade (responsibility assignment) são os conceitos desse conhecimento. A restrição de responsabilidade define que, em certas condições, um agente não pode ser considerado responsável pela violação da norma, enquanto a confirmação de responsabilidade define que, em dadas condições, um agente deve ser considerado responsável pela violação da norma.

Retomando o exemplo do atropelamento, um motorista com mais de 18 anos teria a sua responsabilidade confirmada neste acidente. Entretanto, caso o motorista tivesse menos de 18 anos, haveria uma restrição de responsabilidade. Ainda neste exemplo, a restrição de responsabilidade também poderia ocorrer caso uma falha mecânica no automóvel impedisse o motorista de ter controle sobre o mesmo e provocasse o excesso de velocidade.

\subsubsection{Conhecimento Reativo}

O Conhecimento Reativo especifica as reações jurídicas que devem ser associadas aos comportamentos descritos pelas normas primárias. O autor justifica a importância deste conhecimento ressaltando que as reações jurídicas, em particular as sanções, desempenham um papel importante no mundo jurídico.

Dois conceitos compõem o Conhecimento Reativo: a Reação (reaction) e a Especificação da Reação (reaction specification). A Reação representa as sanções e as compensações que existem no sistema jurídico, sendo as primeiras associadas aos comportamentos indesejáveis, e as segundas aos comportamentos desejáveis. A Especificação da Reação associa uma norma primária a uma dada reação, especificando a 
relação de causa e conseqüência entre a violação / observação da norma e a reação prescrita, respectivamente, uma sanção ou uma compensação.

No exemplo do atropelamento, a norma seria "é proibido abandonar o local do acidente sem prestar socorro”, enquanto a especificação da reação associada a esta norma poderia ser a sanção “detenção de 6 a 12 meses e suspensão da carteira de habilitação por até 1 ano”. A aplicação da sanção ao motorista causador do acidente pelo juiz poderia ser “detenção por 6 meses e suspensão da carteira de habilitação por 1 ano”. Entretanto, esta aplicação não é representada pelo Conhecimento Reativo e sim pelo Conhecimento MetaJurídico, que tem entre as suas funções a adjudicação, que é o poder do juiz de aplicar a sanção, ou seja, de determinar a sentença judicial.

\subsection{Visão Geral da Ontologia Funcional do Direito}

A figura 4.3 ilustra a forma pela qual as categorias de conhecimento identificadas pela Ontologia Funcional do Direito desempenham suas respectivas funções no sistema jurídico.

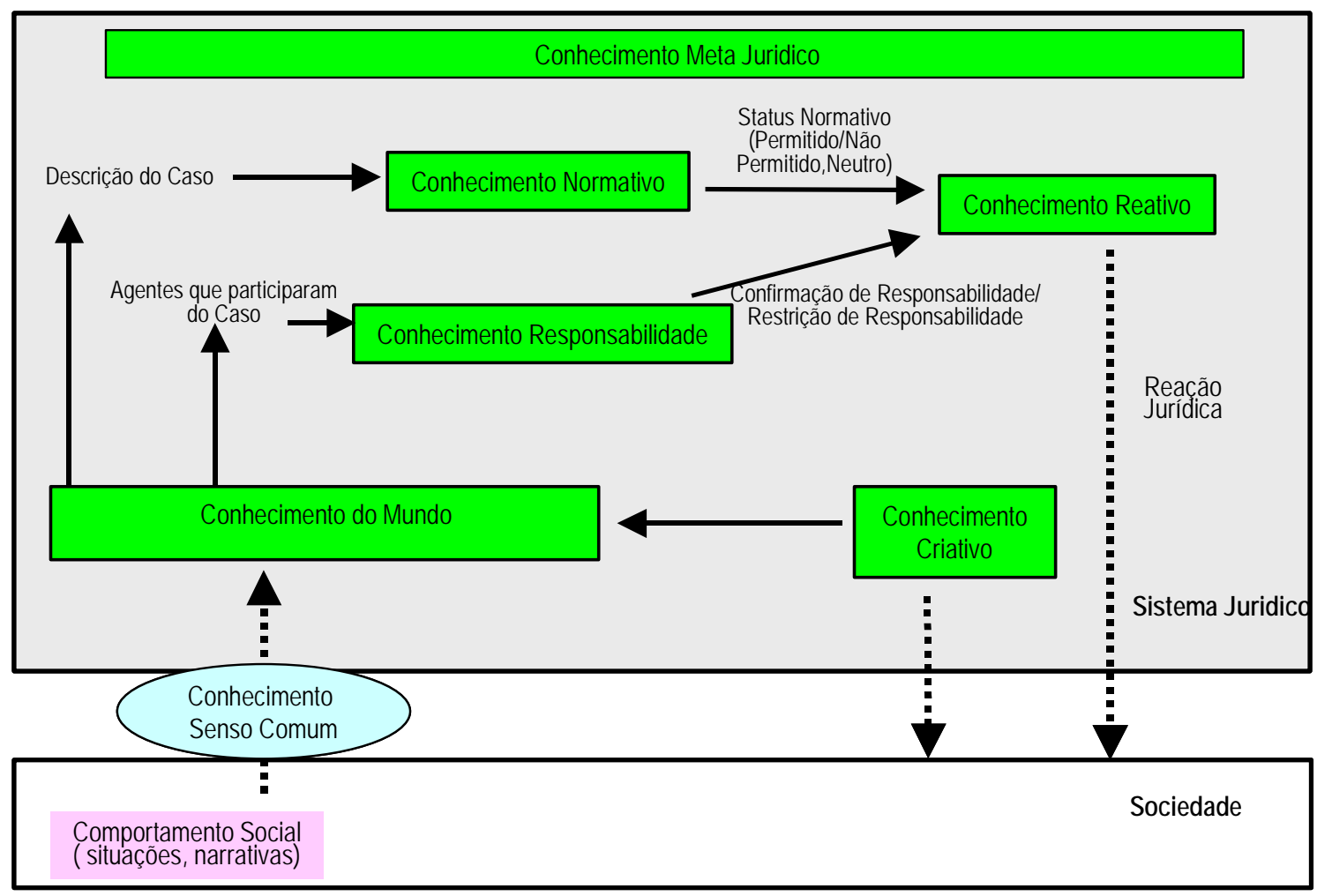

Figura 4.3: Visão geral da Ontologia Funcional do Direito (VALENTE, 1995, p. 74)

O ciclo principal se inicia com a ocorrência de um comportamento social, que pode ser uma situação do mundo real, ou uma narrativa que descreve uma situação, por exemplo 
“João atropela aluno na saída da escola e foge do local do acidente”. Essa situação é então interpretada pelo Conhecimento Do Mundo, que (i) gera uma descrição desta situação, o Caso "motorista provoca atropelamento e foge do local”, e (ii) produz uma lista dos agentes que causaram a situação - “indivíduo João”. O Caso é então analisado pelo Conhecimento Normativo, que constata que este violou uma norma jurídica - “é proibido abandonar o local do acidente sem prestar socorro”. O resultado dessa análise é a Status Normativo do Caso, que pode ser Permitido, Não Permitido ou Neutro. Nesse exemplo o Status Normativo é "não permitido". Em paralelo, o Conhecimento De Responsabilidade analisa os agentes que participaram do Caso e conclui que o indivíduo João tem sua responsabilidade confirmada neste caso e, portanto, tem-se a Confirmação de Responsabilidade do individuo João. O Status Normativo - "não permitido” - e o agente responsável pela situação - “indivíduo João” - são então analisados pelo Conhecimento Reativo, que especifica uma Reação. Nesse exemplo, a reação poderia ser “detenção de 6 a 12 meses e suspensão da carteira de habilitação por até 1 ano”.

Além deste ciclo principal, a figura 4.2 mostra um ciclo secundário que envolve o Conhecimento do Mundo e o Conhecimento Criativo. Esse ciclo representa a criação de uma nova entidade do sistema jurídico. Essa nova entidade, cuja criação é função do Conhecimento Criativo, passa a ser considerada pelo Conhecimento do Mundo. Finalmente, o Conhecimento Meta-Jurídico refere-se a todas as entidades envolvidas no sistema jurídico, promovendo a resolução de conflitos entre elas, quando estes ocorrem. Neste exemplo, o Conhecimento Meta-Jurídico poderia produzir a sentença do juiz: “detenção por 6 meses e suspensão da carteira de habilitação por 1 ano”.

\subsection{Considerações Finais}

Este capítulo apresentou a Ontologia Funcional do Direito, proposta por Valente (1995), que propõe um conjunto de categorias de conhecimento para representar e raciocinar com o conhecimento jurídico.

A Ontologia Funcional do Direito desempenha um duplo papel no desenvolvimento deste trabalho, ambos associados à idéia de modelo. Segundo Dupuy (1999), a ciência é a única atividade humana na qual a palavra "modelo” tem um sentido inverso daquele da língua usual. Enquanto na língua usual um “modelo” é algo digno de ser seguido e imitado, por exemplo, um funcionário modelo ou uma escola modelo, para a ciência “modelo” é uma representação parcial da realidade, uma imitação. Assim, por um lado, a Ontologia 
Funcional do Direito forneceu o modelo, no sentido científico da palavra, para o desenvolvimento de uma Ontologia Funcional de Reputação, visto que foi utilizada uma representação da realidade semelhante àquela ali proposta. Por outro lado, essa ontologia desempenhou o papel de modelo a ser imitado, no sentido que foi um excelente exemplo de como é possível representar o conhecimento de uma área tão distinta da IA, no caso a Teoria do Direito, em termos formais e automatizáveis.

O próximo capítulo apresenta a Ontologia Funcional de Reputação, desenvolvida a partir das categorias de conhecimento propostas pela Ontologia Funcional do Direito. 


\section{Ontologia Funcional de Reputação}

O objetivo deste capítulo é apresentar a Ontologia Funcional de Reputação. Para tanto, foi adotada a seguinte organização. A seção 5.1 justifica a utilização da Ontologia Funcional do Direito (VALENTE, 1995) como base para o desenvolvimento da Ontologia Funcional de Reputação, e oferece uma visão geral dessa ontologia. A seção 5.2 apresenta a estratégia de desenvolvimento adotada para a construção da ontologia. O seu objetivo e escopo são apresentados na seção 5.3. A seção 5.4 apresenta as categorias de conhecimento que formam essa Ontologia Funcional de Reputação, enquanto a seção 5.5 discute a sua implementação em OWL DL. Finalmente, a seção 5.6 apresenta algumas considerações sobre a construção desta ontologia. Cabe ressaltar que a avaliação da ontologia é objeto do capítulo 6.

\subsection{Introdução}

Segundo Valente (1995, p. 41), grande parte das pesquisas em IA \& Direito tornam-se repetições de variações de "soluções de trabalho" quando não possuem uma base ontológica clara, que permita entender porque e como os sistemas especialistas jurídicos funcionam. Esse argumento pode ser estendido para as pesquisas em reputação, visto que, em muitos casos, essas pesquisas são variações empíricas de conceitos baseados no senso comum, implementados em modelos matemáticos e testados em sucessivos ciclos de tentativa e erro. Assim, a análise desses modelos é prejudicada pela falta de clareza e pela não explicitação dos conceitos envolvidos.

A Ontologia Funcional de Reputação proposta nesse trabalho representa uma grande parte do conhecimento científico sobre reputação por meio de categorias e conceitos, estruturados de forma que possam apoiar a implementação de modelos de reputação para agentes de software, escapando assim do senso comum que norteia alguns dos trabalhos sobre o tema (YU e SINGH, 2002; CARBO et al., 2003 entre outros).

A abordagem adotada neste trabalho consiste em estender as categorias da Ontologia Funcional do Direito (VALENTE, 1995) a fim de representar o mecanismo de controle social executado subjetivamente por cada um dos agentes em uma sociedade de 
agentes. Esse mecanismo produz a crença que reflete a avaliação da conduta dos agentes, qual seja, a sua reputação.

A justificativa para a adoção de tal abordagem é a similaridade existente entre uma norma social e uma norma jurídica, visto que uma norma primária (ver seção 4.2.3) pode ser tanto uma norma social como uma norma jurídica (HART, 1961). Enquanto no mundo jurídico a violação da norma jurídica gera uma punição legal do agente, no mundo social a má reputação é a penalidade associada ao comportamento que viola a norma social (CASTELFRANCHI et al., 1998a).

Assim, a Ontologia Funcional de Reputação foi construída a partir da Ontologia Funcional do Direito (VALENTE, 1995) através das seguintes extensões: (i) a ampliação do conceito de norma jurídica para norma social, (ii) a substituição da reação jurídica (sanção ou compensação) pela reação social (má reputação ou boa reputação), e (iii) a interiorização do mecanismo de controle social, que passa a existir na 'mente' do agente e não mais como instituição jurídica externa a ele. De forma análoga à Ontologia Funcional do Direito, a distinção entre as categorias da Ontologia Funcional de Reputação é realizada de acordo com uma perspectiva funcional, segundo a qual cada componente do sistema reputativo existe para cumprir uma função específica no esforço para atingir objetivos sociais mais amplos, como a confiança, a reciprocidade e a cooperação social.

A Ontologia Funcional de Reputação envolve cinco das sete categorias primitivas da Ontologia Funcional do Direito (ver seção 4.2): Conhecimento do Mundo, Conhecimento Normativo, Conhecimento de Responsabilidade, Conhecimento Reativo e Conhecimento de Senso Comum. As demais categorias, que são o Conhecimento MetaJurídico e o Conhecimento Criativo, não foram utilizadas pelo presente trabalho.

Uma visão da interação entre as quatro principais categorias de conhecimento da Ontologia Funcional de Reputação é apresentada na figura 5.1, inspirada em (VALENTE, 1995, p. 74). A sociedade de agentes e o comportamento dos agentes são representados pelo retângulo inferior, enquanto o retângulo superior representa as categorias de conhecimento que compõem o sistema reputativo existente na "mente” do agente.

De forma análoga à Ontologia Funcional do Direito (ver figura 4.3), na Ontologia Funcional de Reputação um ciclo reputativo começa com a interpretação do comportamento social do agente, função da categoria Conhecimento do Mundo. Esta categoria descreve o comportamento do agente em termos de casos, ou situações, de forma que esse comportamento possa ser interpretado pelas demais categorias da ontologia. Após esse primeiro passo, o Conhecimento Normativo é capaz de classificar o caso, por meio de 
um status normativo, de acordo com as normas sociais vigentes. O Conhecimento de Responsabilidade então define se o agente deve ser considerado responsável pelo comportamento apresentado (confirmação de responsabilidade) ou não (restrição de responsabilidade). Finalmente, a partir do status normativo e da confirmação da responsabilidade do agente no caso, o Conhecimento Reputativo é capaz de definir a reputação do agente, como uma recompensa (boa reputação) ou penalidade (reputação ruim).

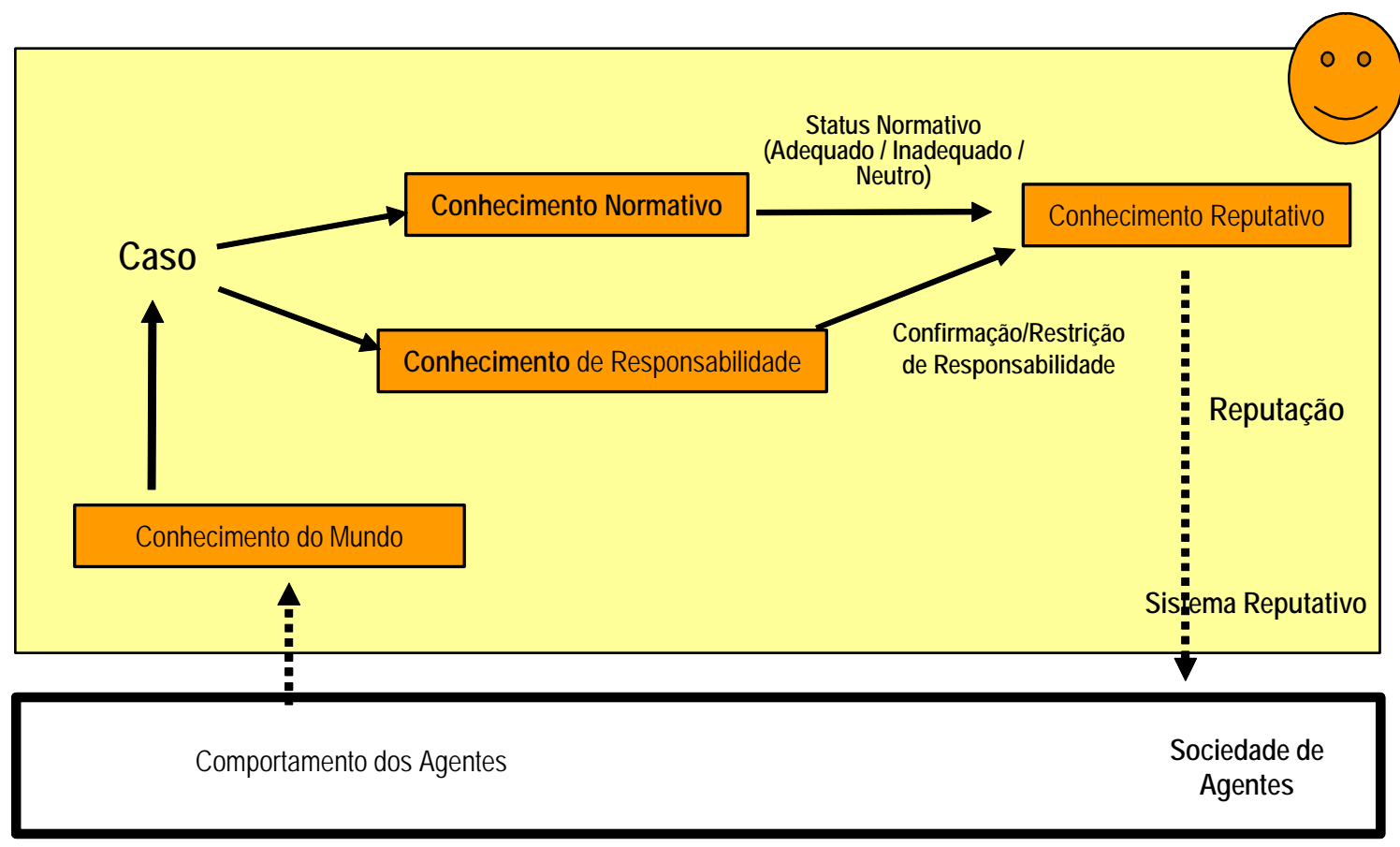

Figura 5.1: Relacionamento entre as Categorias de Conhecimento da Ontologia Funcional de Reputação

\subsection{Estratégia de Desenvolvimento da Ontologia}

A Ontologia Funcional de Reputação foi desenvolvida de acordo com a metodologia para construção de ontologias proposta por Uschold e Gruninger (1996) descrita na seção 3.2 deste texto. A escolha desta metodologia deveu-se à sua adequação à natureza desse trabalho de pesquisa, visto tratar-se de um projeto executado por apenas uma pessoa, e não por uma equipe, e com um ciclo de vida mais curto que os projetos de maior envergadura. Além disso, esta metodologia descreve de forma clara e objetiva as atividades relacionadas à fase de avaliação de uma ontologia.

A metodologia adotada é composta por cinco fases (ver seção 3.2): (i) a identificação do objetivo e escopo, (ii) a construção da ontologia, (iii) a avaliação da 
ontologia, (iv) a documentação da ontologia e (v) o desenvolvimento de guias de orientação.

A primeira fase consistiu na identificação do objetivo da Ontologia Funcional de Reputação e na definição do escopo da mesma. Esse escopo foi definido por meio da formulação de questões de competência em linguagem natural. A seção 5.3 desse capítulo descreve o resultado desta fase.

Durante a segunda fase, que consistiu na construção da ontologia, foram realizadas as atividades de captura de conceitos, integração com a Ontologia Funcional do Direito e codificação da Ontologia Funcional de Reputação. A atividade de captura dos conceitos incluiu a identificação, descrição e escolha de nomes dos conceitos associados à noção de reputação, assim como a identificação dos relacionamentos entre eles. A atividade de integração consistiu na agregação das categorias e conceitos da Ontologia Funcional do Direito à Ontologia Funcional de Reputação. Estas duas atividades estão descritas na seção 5.4 desse capítulo. A atividade de codificação da ontologia incluiu a escolha da linguagem de implementação, OWL DL, e das ferramentas utilizadas, quais sejam, o editor de ontologias Protégé e o motor de inferência (reasoner) RACER. A seção 5.5 desse capítulo descreve o resultado desta atividade.

A avaliação da ontologia, que foi realizada na terceira fase do desenvolvimento, consistiu na verificação das características da Ontologia Funcional de Reputação, como a sua expressividade e consistência. Nesta fase, as questões de competência, até então formuladas em linguagem natural como forma de delimitar o escopo, foram descritas em linguagem formal. O resultado desta fase é apresentado no capitulo 6.

Cabe ressaltar que houve uma grande interação entre a atividade de captura de conceitos, a atividade de integração com a Ontologia Funcional do Direito e a fase de avaliação da ontologia. Os conceitos que resultaram da atividade de captura foram detalhados durante a integração das ontologias, e o resultado de ambas atividades foi refinado durante a codificação e avaliação da ontologia.

As atividades propostas na quarta e quinta fase, quais sejam, a documentação da ontologia e a definição de guias de desenvolvimento, foram executadas ao longo das três fases descritas acima.

A figura 5.2 ilustra o ciclo de desenvolvimento da ontologia, mostrando as fases e as atividades executadas. 


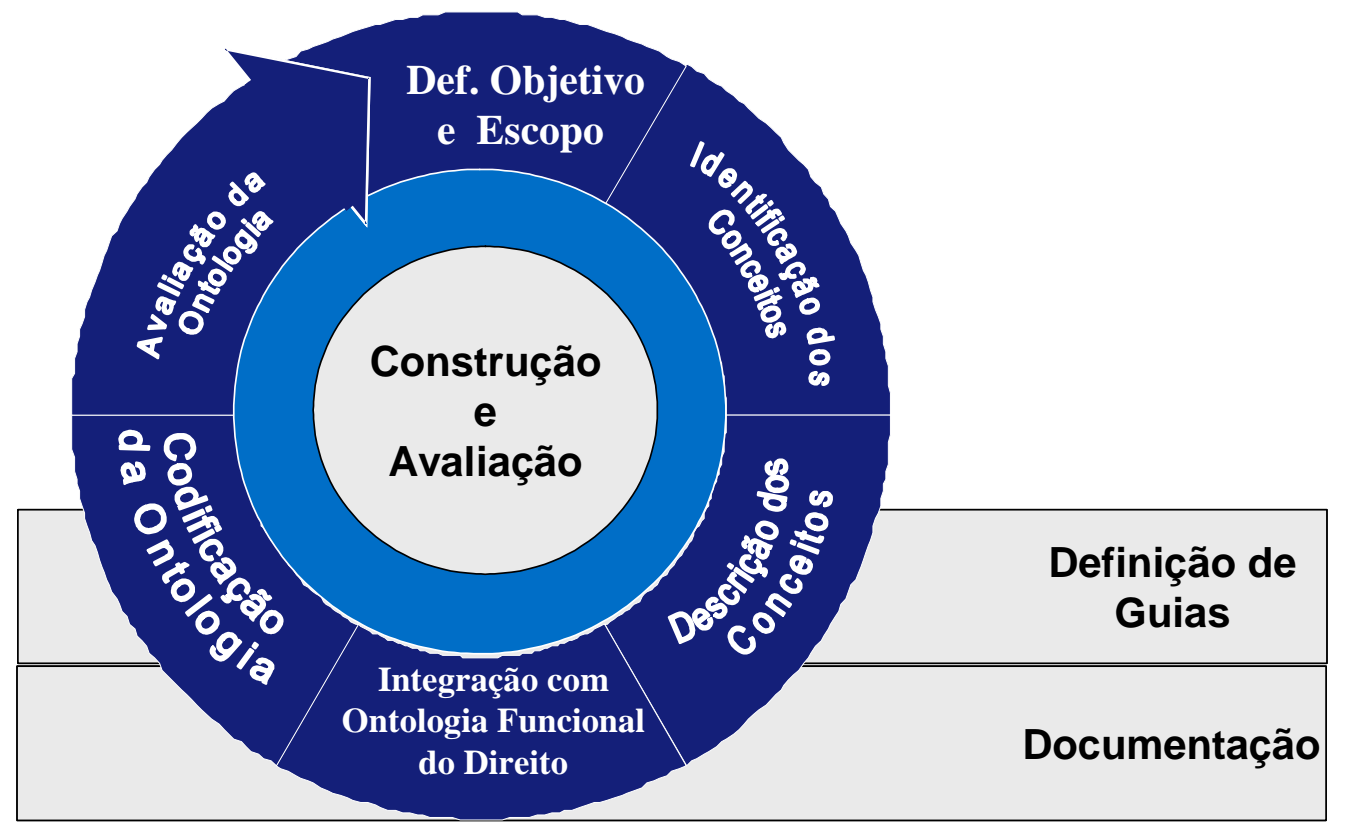

Figura 5.2: Ciclo de desenvolvimento da Ontologia Funcional de Reputação

Algumas técnicas de desenvolvimento de ontologias foram adotadas na construção desta ontologia. O objetivo dessas técnicas é facilitar o entendimento dos conceitos e relacionamentos que formam a ontologia e tornar menos árdua a sua futura manutenção e extensão:

- Qualificar corretamente os conceitos por meio de nomes representativos, mesmo que sejam compostos por diversas palavras, de forma que o termo tenha sentido em um contexto fora da sua hierarquia. Por exemplo, usar o nome “Processo de Avaliação de Reputação”, ao invés de apenas “Avaliação de Reputação";

- Descrever os conceitos em linguagem natural, evitando o uso das mesmas palavras usadas para nomear o conceito. Por exemplo, a definição do conceito “Conhecimento de Senso Comum” não utiliza a expressão "senso comum”: “O Conhecimento de Senso Comum é a raiz da hierarquia de conceitos que constituem o conhecimento geral que se considera acessível a todos agentes (...).”;

- Utilizar exemplos sempre que possível na descrição dos conceitos, para facilitar a compreensão dos mesmos;

- Usar regras e técnicas de codificação na implementação da ontologia, de maneira a facilitar o entendimento e a manutenção do código. Por exemplo, 
utilizar um padrão para a formação de nomes de classes e propriedades. A seção 5.5 descreve essas regras e técnicas de forma detalhada.

\subsection{Objetivo e Escopo da Ontologia Funcional de Reputação}

\subsubsection{Objetivo da Ontologia}

O objetivo da ontologia apresentada nesse trabalho é oferecer uma perspectiva funcional para a análise da reputação como mecanismo de controle social. O método utilizado para atingir esse objetivo foi agregar o conhecimento sobre reputação disperso na literatura de IA, usando os aspectos da reputação propostos por Bromley (1993) e por Ferris et al. (2003) como quadro conceitual, e integrá-lo às categorias da Ontologia Funcional do Direito proposta por Valente (1995).

De acordo com as possíveis formas de utilização de uma ontologia (USCHOLD e GRUNINGER, 1996), descritas na seção 3.1.2, a Ontologia Funcional de Reputação pode ser usada para promover a comunicação e a interoperabilidade, assim como em Engenharia de sistemas:

- Comunicação - a ontologia proposta mitiga a dificuldade de compreensão gerada pela ambigüidade de termos usados pelos diversos modelos e sistemas de reputação, através da captura e representação de múltiplos termos e da identificação de sinônimos;

- Interoperabilidade - tal ontologia pode facilitar a interoperabilidade em sistemas multiagentes envolvendo agentes que implementam distintos sistemas de reputação, servindo como uma interlingua entre eles (CASARE e SICHMAN, 2005b);

- Engenharia de sistemas - esta ontologia pode apoiar o projeto e desenvolvimento de sistemas de reputação, servindo como guia tanto para a identificação requisitos quanto para a definição do modelo de reputação a ser utilizado.

Em relação aos processos envolvidos na geração da reputação, cabe ressaltar que o objetivo da Ontologia Funcional de Reputação é fornecer um arcabouço que inclui esses processos como seus conceitos. Entretanto, a sua representação por meio de técnicas específicas de modelagem de processos e tarefas, e a sua implementação em procedimentos computacionais está fora do escopo deste trabalho. 


\subsubsection{Escopo e Questões de Competência}

O escopo da Ontologia Funcional de Reputação foi definido por meio de questões de competência que descrevem em linguagem natural, e de forma interrogativa, os requisitos que esta deve atender.

Essas questões de competência definem o escopo da ontologia em relação à sua capacidade de representar os termos e noções utilizadas pelos seis modelos e sistemas de reputação apresentados na seção 2.2. Tais questões restringem-se à categoria Conhecimento Reputativo, visto ser esta a categoria que representa as noções de reputação. Cabe ressaltar ainda que a representação da noção de confiança não faz parte do escopo desta ontologia.

A escolha destes seis modelos e sistemas como delimitadores do escopo da ontologia é resultado da avaliação de diversos modelos e sistemas de reputação ${ }^{25}$. Tal escolha foi guiada pelos seguintes princípios:

i) Selecionar modelos e sistemas que discutem as diversas dimensões da reputação propostas pelas pesquisas realizadas em Ciências Humanas (ver seção 2.1), em busca de definições técnicas detalhadas para as idéias aí apresentadas. Alguns exemplos são:

- Bromley (1993) sugere que a avaliação da reputação pode ser feita considerando-se apenas o nível de estima ou também os atributos que a influenciam. Tal aspecto é tratado pelo Sistema de Reputação e Endosso (MAXIMILIEN e SINGH, 2002), que propõe um modelo para a avaliação da reputação por meio de atributos e seus respectivos pesos;

- Ferris et al.(2003) consideram que o comportamento mais recente deve ter maior peso na manutenção da reputação que o mais antigo. Para tanto, o sistema Sporas (ZACHARIAS e MÃES, 2000) propõe um mecanismo para a aplicação de um fator de depreciação no valor de reputações mais antigas, dando maior importância às avaliações mais recentes;

- Bromley discute a relação entre a reputação e a fonte de informação utilizada na sua formação. Este aspecto é detalhado na Tipologia de Reputação (MUI et

\footnotetext{
${ }^{25}$ (ZACHARIA e MAES, 2000; CARBO et al., 2001; ROUCHIER et al., 2001; CARTER et al., 2002; CONTE e PAOLUCCI, 2002; SEN e SAJJA, 2002; MAXIMILIEN e SINGH , 2002; PUJOL et al., 2002; MUI et al., 2002a,2003; SABATER, 2003, YU e SINGH, 2003; HUYNH et al., 2004; KLOS e LA POUTRÉ, 2004; FULLAM e BARBER, 2004 entre outros).
} 
al.,2002a) , que representa a reputação de um individuo de acordo com a natureza da fonte de informação.

ii) Oferecer um panorama das pesquisas realizadas sobre reputação em IA, valorizando a originalidade dos trabalhos. Foram incluídos modelos e sistemas com diversas abordagens da dimensão social da reputação:

- reputação baseada em papéis sociais (CARTER et al., 2002);

- reputação avaliada a partir das relações sociais existentes entre os agentes (SABATER, 2003; ZACHARIA e MAES, 2000);

- características da transmissão da reputação em uma rede social (CONTE e PAOLUCCI, 2002).

As questões de competência, apresentadas na tabela 5.1, foram organizadas a partir dos critérios de análise apresentados na seção 2.2.8 deste texto, nomeadamente, natureza da reputação, papel envolvido na formação da reputação, tipo da reputação segundo a fonte de informação utilizada, valor e fator de avaliação da reputação, manutenção e distribuição da reputação.

Tabela 5.1: Questões de competência segundo os critérios de análise da reputação

\begin{tabular}{|c|c|c|c|c|c|}
\hline $\begin{array}{l}\text { Critério } \\
\text { Modeld } \\
\text { SSistema }\end{array}$ & Natureza & Papel & $\begin{array}{c}\text { Tipo de } \\
\text { Reputação }\end{array}$ & $\begin{array}{l}\text { Valor e Fator de } \\
\text { Avaliação }\end{array}$ & $\begin{array}{l}\text { Manutenção e } \\
\text { Distribuição }\end{array}$ \\
\hline $\begin{array}{c}\text { Modelo } \\
\text { Cognitivo } \\
\text { de } \\
\text { Reputação } \\
\text { (Conte e } \\
\text { Paolucci) }\end{array}$ & $\begin{array}{c}\text { Qual é a } \\
\text { natureza } \\
\text { da } \\
\text { reputação } \\
\text { do agente? }\end{array}$ & $\begin{array}{l}\text { Qual é o papel } \\
\text { desempenhado pelos } \\
\text { conjuntos de agentes } \\
\text { alvos, avaliadores, } \\
\text { transmissores e } \\
\text { beneficiários? }\end{array}$ & $\begin{array}{c}\text { O que é a } \\
\text { Imagem? } \\
\text { O que é a } \\
\text { reputação? }\end{array}$ & & $\begin{array}{c}\text { O que são os } \\
\text { aspectos } \\
\text { envolvidos na } \\
\text { transmissão da } \\
\text { reputação: o que } \\
\text { transmitir, para } \\
\text { quem transmitir, } \\
\text { como transmitir e } \\
\text { por que } \\
\text { transmitir? }\end{array}$ \\
\hline $\begin{array}{c}\text { Modelo } \\
\text { Tipologia } \\
\text { de } \\
\text { Reputação } \\
\text { (Mui et al.) }\end{array}$ & $\begin{array}{c}\text { Qual é a } \\
\text { natureza } \\
\text { da } \\
\text { reputação } \\
\text { do } \\
\text { individuo e } \\
\text { do grupo } \\
\text { de } \\
\text { indivíduos? }\end{array}$ & & $\begin{array}{c}\text { O que são: a } \\
\text { reputação direta, a } \\
\text { de interação, a } \\
\text { observada, a } \\
\text { indireta, a derivada } \\
\text { anterior, a } \\
\text { derivada de grupo } \\
\text { e a propagada? }\end{array}$ & & \\
\hline
\end{tabular}




\begin{tabular}{|c|c|c|c|c|c|}
\hline $\begin{array}{l}\text { Critério } \\
\text { Modeld } \\
\text { ISistema }\end{array}$ & Natureza & Papel & $\begin{array}{c}\text { Tipo de } \\
\text { Reputação }\end{array}$ & $\begin{array}{l}\text { Valor e Fator de } \\
\text { Avaliação }\end{array}$ & $\begin{array}{l}\text { Manutenção e } \\
\text { Distribuição }\end{array}$ \\
\hline $\begin{array}{l}\text { Sistemas } \\
\text { Histos e } \\
\text { Sporas } \\
\text { (Zacharia e } \\
\text { Maes) }\end{array}$ & $\begin{array}{c}\text { Qual é a } \\
\text { natureza } \\
\text { da } \\
\text { reputação } \\
\text { do usuário } \\
\text { do } \\
\text { sistema? }\end{array}$ & $\begin{array}{l}\text { Qual é o papel } \\
\text { desempenhado pelos } \\
\text { usuários do sistema? }\end{array}$ & & $\begin{array}{l}\text { O que é a avaliação da } \\
\text { reputação? } \\
\text { O que é o valor da } \\
\text { reputação? } \\
\text { O que é a relação } \\
\text { social entre os } \\
\text { usuários? } \\
\text { O que é a reputação do } \\
\text { avaliador? }\end{array}$ & $\begin{array}{c}\text { O que faz o } \\
\text { componente } \\
\text { central do } \\
\text { sistema? }\end{array}$ \\
\hline $\begin{array}{l}\text { Sistema } \\
\text { Reputação } \\
\text { cl papéis } \\
\text { (Carter et } \\
\text { al.) }\end{array}$ & $\begin{array}{c}\text { Qual é a } \\
\text { natureza } \\
\text { da } \\
\text { reputação } \\
\text { do usuário } \\
\text { do } \\
\text { sistema? }\end{array}$ & $\begin{array}{c}\text { Qual é o papel } \\
\text { desempenhado pelos } \\
\text { usuários do sistema? }\end{array}$ & & $\begin{array}{l}\text { O que é o valor da } \\
\text { reputação? } \\
\text { O que é o papel social? }\end{array}$ & $\begin{array}{c}\text { O que faz o } \\
\text { componente } \\
\text { central do } \\
\text { sistema? } \\
\text { O que é o } \\
\text { estabelecimento } \\
\text { da reputação? }\end{array}$ \\
\hline $\begin{array}{l}\text { Sistema } \\
\text { de } \\
\text { Reputação } \\
\text { e Endosso } \\
\text { (Maximiliam } \\
\text { e Singh) }\end{array}$ & $\begin{array}{c}\text { Qual é a } \\
\text { natureza } \\
\text { da } \\
\text { reputação } \\
\text { do serviço } \\
\text { Web? }\end{array}$ & $\begin{array}{l}\text { Qual é o papel } \\
\text { desempenhado pelo } \\
\text { serviço Web, pelo } \\
\text { usuário do sistema e } \\
\text { pelo agente WSAP? }\end{array}$ & & $\begin{array}{l}\text { O que é o algoritmo de } \\
\text { avaliação? } \\
\text { O que é a avaliação do } \\
\text { serviço? } \\
\text { O que é o valor da } \\
\text { reputação? } \\
\text { O que são os atributos } \\
\text { e seus pesos? }\end{array}$ & $\begin{array}{l}\text { O que fazem as } \\
\text { agências de } \\
\text { reputação? } \\
\text { O que é o } \\
\text { algoritmo de } \\
\text { reputação? }\end{array}$ \\
\hline $\begin{array}{l}\text { Sistema } \\
\text { Regret } \\
\text { (Sabater) }\end{array}$ & $\begin{array}{c}\text { Qual é a } \\
\text { natureza } \\
\text { da } \\
\text { reputação } \\
\text { do agente? }\end{array}$ & $\begin{array}{l}\text { Qual é o papel do } \\
\text { usuário do comércio } \\
\text { eletrônico? }\end{array}$ & $\begin{array}{c}\text { O que é a } \\
\text { confiança direta? } \\
\text { O que são: a } \\
\text { reputação de } \\
\text { testemunha, a de } \\
\text { vizinhança, a de } \\
\text { sistema? }\end{array}$ & $\begin{array}{l}\text { Qual é a função da } \\
\text { credibilidade? }\end{array}$ & \\
\hline
\end{tabular}

\subsection{Categorias de Conhecimento da Ontologia Funcional de Reputação}

Esta seção apresenta o resultado das atividades de captura dos conceitos e de integração com a Ontologia Funcional do Direito, descrevendo as categorias da Ontologia Funcional de Reputação e os conceitos a elas associados. Essa descrição é feita em linguagem natural e complementada por figuras com os diagramas de hierarquia de classes gerados pelo ambiente de desenvolvimento Protégé, e eventualmente por tabelas mostrando os relacionamentos entre os conceitos.

A Ontologia Funcional de Reputação é formada por duas grandes categorias: o Conhecimento de Reputação e o Conhecimento de Senso Comum. A primeira representa o 
conhecimento sobre o sistema reputativo, sendo formado por quatro subcategorias: Conhecimento Reputativo, Conhecimento De Responsabilidade, Conhecimento Normativo e Conhecimento Do Mundo. A segunda categoria agrupa a hierarquia de conceitos que representam os elementos do senso comum relevantes para o Conhecimento de Reputação.

A figura 5.3 mostra o Conhecimento De Reputação, o Conhecimento de Senso Comum e as suas subcategorias e conceitos. Esta figura, assim como as demais de mesma natureza utilizadas neste texto, foram geradas por meio do Plug-in OWLViz.

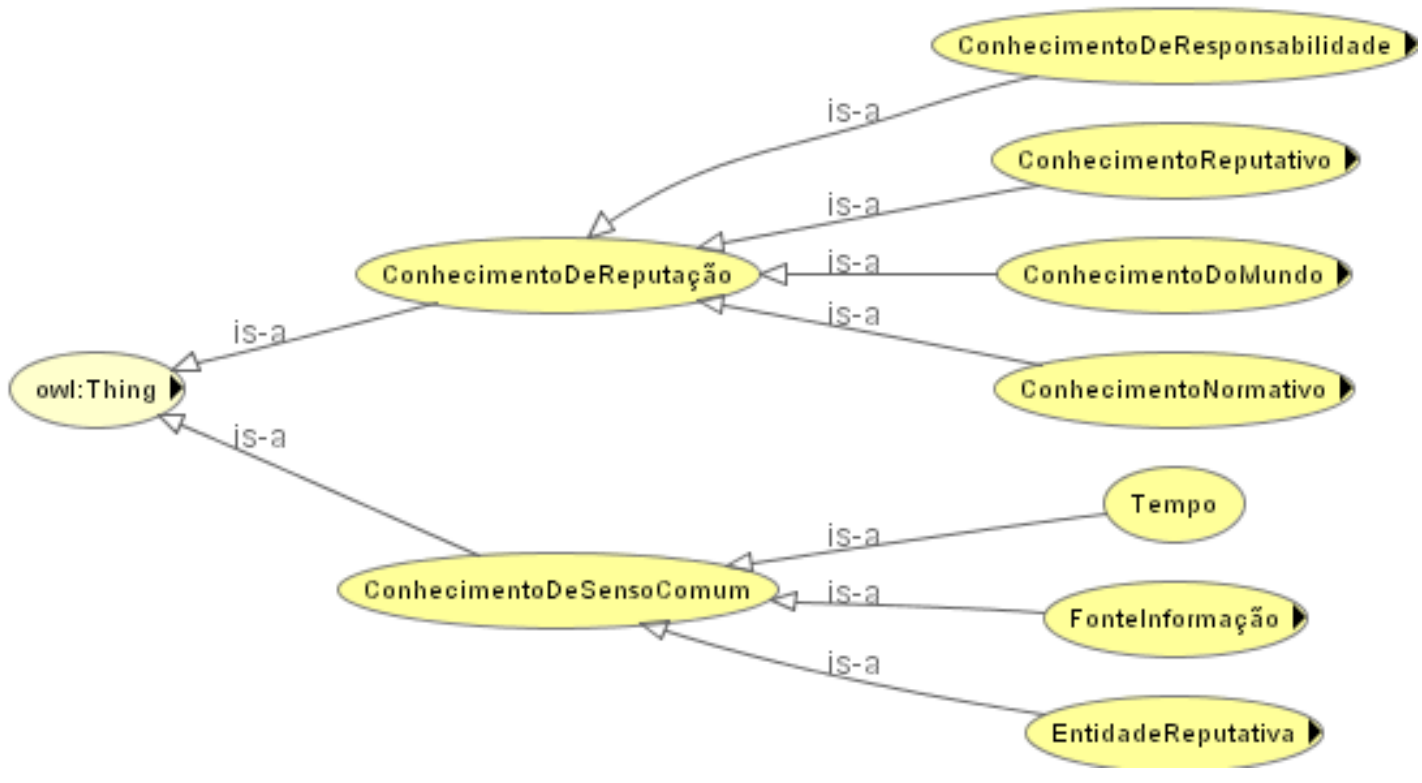

Figura 5.3: Representação das categorias da Ontologia Funcional de Reputação

As seções seguintes apresentam as categorias e subcategorias da Ontologia Funcional de Reputação na seguinte ordem: Conhecimento Reputativo, Conhecimento de Senso Comum, Conhecimento do Mundo, Conhecimento Normativo e Conhecimento de Responsabilidade.

\subsubsection{Conhecimento Reputativo}

O Conhecimento Reputativo é a categoria mais detalhada desta ontologia. Foi inspirada no Conhecimento Reativo da Ontologia Funcional do Direito (VALENTE, 1995) e tem como função definir a recompensa ou a punição de um agente, com uma boa reputação ou com uma má reputação.

Segundo Bromley (1993, p. 29, 217), a reputação é ao mesmo tempo um produto e um processo social. Um produto, ou propriedade, no sentido que, a cada instante, ela consiste no acordo de opiniões em algum nível; um processo no sentido que ela depende do fluxo de informações e das influências existentes na rede social. 
O Conhecimento Reputativo representa a reputação como uma propriedade e como um processo através dos seguintes conceitos: Propriedade da Reputação, Processo Reputativo, Papel Reputativo, Componente de Cálculo da Reputação e Componente de Propagação da Reputação. Os conceitos Propriedade da Reputação e Processo Reputativo representam este caráter dual da reputação, ao mesmo tempo um produto e um processo social. O terceiro conceito, Papel Reputativo, representa os papéis envolvidos na formação de uma reputação. O conceito Componente de Cálculo da Reputação representa os componentes envolvidos na avaliação de uma reputação, tal como os atributos de avaliação e a relevância dos mesmos. O quinto conceito, Componente de Propagação da Reputação, representa os diversos fatores envolvidos na transmissão e recepção de uma reputação, tal como a forma e o objetivo da transmissão.

A figura 5.4 mostra a categoria Conhecimento Reputativo e o primeiro nível dos conceitos que a compõem.

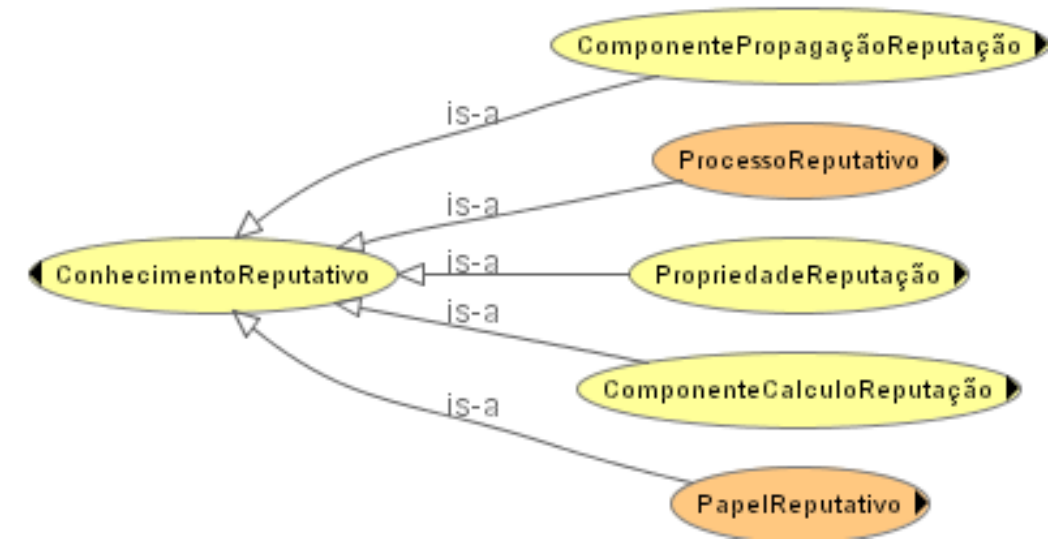

Figura 5.4: Representação dos conceitos da categoria de Conhecimento Reputativo

A seguir, os 45 conceitos que compõem esta categoria de conhecimento são apresentados em detalhes. Ao final desta seção, a figura 5.9 apresenta o diagrama da hierarquia contendo todos os conceitos.

\subsubsection{Propriedade da Reputação}

O conceito Propriedade da Reputação permite identificar a natureza e o tipo de uma reputação. Essas duas noções são representadas pelos conceitos Natureza da Reputação e Tipo de Reputação, respectivamente.

\subsection{Natureza da Reputação}

O conceito Natureza da Reputação permite distinguir uma reputação de acordo com a entidade que é o alvo da mesma. Segundo Bromley (1993, p. 4), as entidades reputacionais (reputational entities) usuais são as pessoas, os grupos de pessoas e as 
corporações, mas ressalta que o termo reputação também pode ser aplicado aos produtos, aos serviços, às áreas geográficas e aos eventos de forma geral, inclusive as atividades.

Os conceitos definidos na Ontologia Funcional de Reputação para representar as distintas naturezas de reputação são: Reputação Individual, Reputação de Grupo, Reputação de Produto, Reputação de Local, Reputação de Evento e Reputação de Atividade.

O conceito Reputação Individual representa a reputação associada a indivíduos ou agentes singulares, como por exemplo, a reputação de uma pessoa ou de agente de software. O conceito Reputação de Grupo representa aquela relacionada às coletividades de indivíduos ou de agentes. Por exemplo, a reputação de uma empresa, de uma universidade ou de um grupo de pesquisa.

O conceito Reputação de Produto designa a reputação de produtos e serviços, tal como a reputação de um carro ou de um serviço Web. O conceito Reputação de Local representa a reputação das localidades geográficas, tal como a reputação de São Paulo ou do Rio de Janeiro. O conceito Reputação de Evento designa a reputação associada aos eventos de forma geral, como o Carnaval ou um congresso de Inteligência Artificial, enquanto o conceito Reputação de Atividade representa a reputação das atividades que podem ser executadas pelos agentes, tais como fumar e praticar esportes.

\subsection{Tipo de Reputação}

O conceito Tipo de Reputação permite classificar uma reputação de acordo com as fontes de informações utilizadas na sua formação, se fontes primárias ou secundárias. As fontes de informações primárias são as experiências diretas dos agentes. As fontes secundárias consistem nas diversas opiniões sobre os agentes que circulam dentro das redes sociais e que não são baseadas em contato direto. Essas opiniões podem ter origens diversas, tais como as informações que relatam experiências vividas, os estereótipos e os preconceitos vigentes em um grupo social (BROMLEY, 1993).

Os termos utilizados para denominar a reputação variam de acordo com o autor e com o tipo de fonte de informação utilizada. Bromley (1993, p. 43-44) chama de Reputação Primária aquela resultante tanto de interações diretas como da observação dessas interações, e chama de Reputação Secundária ou estendida aquela que resulta das opiniões que circulam em uma rede social. Conte e Paolucci (2002, p. 72) chamam de Imagem a avaliação derivada das fontes primárias de informações, e adotam o termo Reputação para a avaliação derivada das fontes secundárias de informações. Yu e Singh 
(2002) nomeiam de crença local a avaliação resultante de interação direta entre os agentes, e de crença total aquela resultante da combinação da crença local e das informações recebidas através da propagação da crença local.

Os conceitos definidos na Ontologia Funcional de Reputação para representar estes distintos tipos de reputação são: Reputação Primária, Reputação Direta, Reputação Observada, Reputação Secundária, Reputação Propagada, Reputação Coletiva e Reputação a Priori.

O conceito Reputação Primária designa a reputação formada a partir das fontes primárias, tais como a interação direta e a observação. Este conceito é especializado por meio de dois conceitos: Reputação Direta e Reputação Observada. O primeiro representa a reputação derivada das interações diretas entre duas entidades, o avaliador e o alvo. O segundo conceito designa a reputação advinda da observação feita pela entidade avaliadora a partir de encontros entre as entidades alvo. Cabe ressaltar que o nome deste conceito, Reputação Observada, foi proposto por Mui at al. (2002a). Um exemplo que ilustra esses conceitos é a reputação que o gerente Pedro tem do funcionário José, que pode ser formada a partir das interações diretas que Pedro teve com José ou da observação das interações deste com os demais colegas.

O conceito Reputação Secundária representa a reputação derivada de fontes indiretas de informação. O termo proposto por Mui et al. (2002a), Reputação Propagada, foi adotado para nomear o conceito que designa a reputação derivada das informações recebidas de outros agentes. Por exemplo, Pedro associa uma má reputação a José porque ouviu Maria dizer que ele é preguiçoso. O conceito Reputação Coletiva representa a reputação que o agente herda dos grupos ao qual pertence. Assim, a reputação que Pedro herda da empresa na qual trabalha ou que José herda da faculdade na qual estudou são exemplos desse tipo de reputação.

A reputação baseada nos preconceitos e estereótipos sociais é representada pelo conceito Reputação a Priori. Segundo Bromley (1993, p. 72, 73), estereótipos típicos estão associados à idade, à etnia, à religião e à nacionalidade de um indivíduo. Os indivíduos identificados por estereótipos são geralmente reconhecidos pela aparência ou pelo sotaque. Esta identificação é então associada a uma variedade de atributos, usualmente prejudiciais ao indivíduo. Um exemplo deste tipo de reputação é aquela associada à nacionalidade ou etnia, como a reputação dos alemães de beberem muita cerveja ou dos índios de serem avessos ao trabalho. 
No limite, o conceito Reputação Coletiva poderia ser considerado como sendo um sub-conceito de Reputação a Priori, pois ambos se referem a grupos de indivíduos, o primeiro a grupos mais restritos, por exemplo uma empresa ou faculdade, e o segundo a grupos mais amplos, como nacionalidades. Entretanto, optou-se por manter esses conceitos independentes por duas razões: (i) os modelos e sistemas de reputação tendem a mantê-los separados (MUI et. al., 2002a); (ii) a noção de preconceito e estereótipo social tem uma conotação negativa na maior parte das vezes (BROMLEY, 1993, p. 72), o que não acontece com a noção de herança de grupo.

5.4.1.1.3 Hierarquia e Relacionamento dos Conceitos de Propriedade da

\section{Reputação}

A figura 5.5 mostra o diagrama da hierarquia dos conceitos que compõem a Propriedade da Reputação.

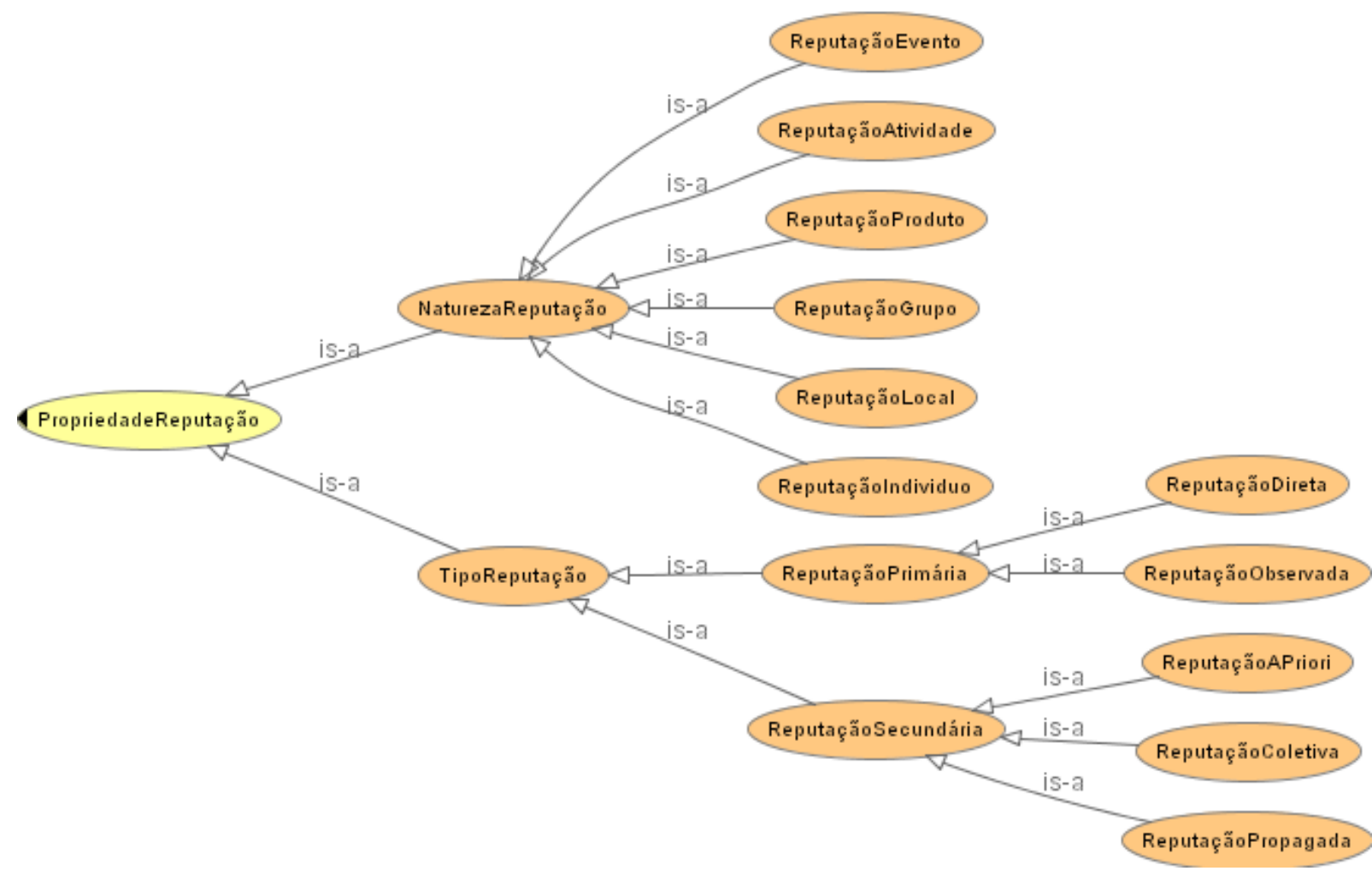

Figura 5.5: Representação do conceito Propriedade da Reputação

A tabela 5.2 apresenta os relacionamentos nos quais os conceitos Natureza da Reputação e Tipo de Reputação são os sujeitos dos mesmos ${ }^{26}$.

\footnotetext{
${ }^{26}$ Os conceitos citados como objeto do relacionamento fazem parte das demais categorias da ontologia e são descritos ao longo deste capítulo.
} 
Tabela 5.2: Relacionamentos de Natureza da Reputação e Tipo de Reputação

\begin{tabular}{|l|l|l|}
\hline Sujeito do relacionamento & \multicolumn{1}{|c|}{ Relacionamento } & Objeto do relacionamento \\
\hline Reputação de Evento & É natureza de reputação de & Evento \\
\hline Reputação de Atividade & É natureza de reputação de & Atividade \\
\hline \multirow{2}{*}{ Reputação de Produto } & É natureza de reputação de & Objeto \\
\cline { 2 - 4 } & É natureza de reputação de & Serviço \\
\hline Reputação de Grupo & É natureza de reputação de & Grupo de Indivíduo \\
\hline Reputação de Local & É natureza de reputação de & Local \\
\hline Reputação de Indivíduo & É natureza de reputação de & Indivíduo \\
\hline Tipo de Reputação & É reputação de & Papel Alvo \\
\hline Reputação Primária & Têm fonte de Informação em & Experiência Direta \\
\cline { 2 - 4 } & Têm fonte de Informação em & Observação \\
\hline Reputação Direta & Têm fonte de Informação em & Experiência Direta \\
\hline Reputação Observada & Têm fonte de Informação em & Observação \\
\hline Reputação Secundária & Têm fonte de Informação em & Preconceito \\
\cline { 2 - 4 } & Têm fonte de Informação em & Herança de Grupo \\
\cline { 2 - 4 } & Têm fonte de Informação em & Informação de Terceiro \\
\hline Reputação A Priori & Têm fonte de Informação em & Preconceito \\
\hline Reputação Coletiva & Têm fonte de Informação em & Herança de Grupo \\
\hline Reputação Propagada & Têm fonte de Informação em & Informação de Terceiro \\
\hline
\end{tabular}

\subsubsection{Papel Reputativo}

O conceito Papel Reputativo representa os diversos papéis envolvidos na formação de uma reputação. Esses papéis podem ser desempenhados pelos indivíduos, pelos grupo de indivíduos da rede social ou pelos agentes de software, por exemplo, aqueles existentes nos sistemas de comércio eletrônico.

Os papéis reputativos foram identificados a partir da noção de conjuntos de entidades alvo, avaliadoras e transmissoras, proposta por Conte e Paolucci (2002), e descrita na seção 2.2.2. São eles: Papel de Alvo, Papel de Transmissor, Papel de Receptor, Papel de Avaliador e Papel de Mantenedor.

O Papel de Alvo é desempenhado por uma entidade reputativa quando esta é o objeto da reputação. O Papel de Transmissor é desempenhado pelas entidades que transmitem as informações sobre a reputação, enquanto o Papel de Receptor é desempenhado por aquelas que recebem essa informação. O Papel de Avaliador é desempenhado pelos agentes que avaliam as demais entidades reputativas, e o Papel de Mantenedor, por aqueles que executam o processo de manutenção da reputação. Por exemplo, após uma reunião de trabalho entre Pedro e José, Pedro conta a Maria, que não participou da reunião, a sua opinião sobre José. Neste caso, Pedro desempenhou o papel de entidade avaliadora e transmissora, José, o papel de alvo e Maria, o papel de receptor.

Em geral, o papel de mantenedor é executado de forma concomitante ao papel de avaliador. Entretanto, há casos onde o processo de manutenção é prerrogativa de uma 
entidade específica, tal como o mecanismo central de manutenção da reputação proposto pelos sistemas Histos e Sporas (ZACHARIA e MAES, 2000), descritos na seção 2.2.4. Nestes sistemas, o papel de mantenedor e de transmissor é desempenhado pelo mecanismo central, enquanto os usuários desempenham os papéis de alvo, avaliador e receptor.

A figura 5.6 mostra o diagrama com a hierarquia de papéis reputativos.

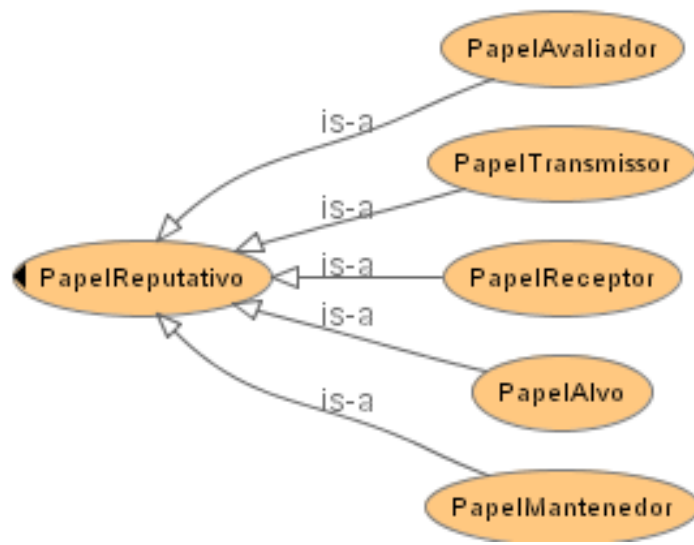

Figura 5.6: Representação do conceito Papel Reputativo

A tabela 5.3 apresenta os relacionamentos nos quais os papéis reputativos são os sujeitos. A maior parte desses relacionamentos tem os processos reputativos como objeto.

Tabela 5.3: Relacionamentos de Papel Reputativo

\begin{tabular}{|l|l|l|}
\hline Sujeito do relacionamento & \multicolumn{1}{|c|}{ Relacionamento } & \multicolumn{1}{|c|}{ Objeto do relacionamento } \\
\hline Papel Alvo & Tem reputação & Tipo de Reputação \\
\hline Papel Transmissor & Tem Processo Reputativo & $\begin{array}{l}\text { Processo de Transmissão da } \\
\text { Reputação }\end{array}$ \\
\hline Papel Receptor & Tem Processo Reputativo & $\begin{array}{l}\text { Processo de Recepção da } \\
\text { Reputação }\end{array}$ \\
\hline Papel Avaliador & Tem Processo Reputativo & $\begin{array}{l}\text { Processo de Avaliação da } \\
\text { Reputação }\end{array}$ \\
\hline Papel Mantenedor & Tem Processo Reputativo & $\begin{array}{l}\text { Processo de Manutenção da } \\
\text { Reputação }\end{array}$ \\
\hline
\end{tabular}

Com exceção do papel de alvo, que pode ser desempenhado por qualquer entidade, como um produto ou uma pessoa, os demais papéis são desempenhados pelas entidades capazes de executar os processos reputativos, descritos a seguir.

\subsubsection{Processos Reputativos e Componentes Associados}

O conceito Processo Reputativo representa os quatro processos envolvidos na noção de reputação: Processo de Avaliação da Reputação, Processo de Manutenção da Reputação, Processo de Transmissão da Reputação e Processo de Recepção da Reputação. Os dois primeiros são responsáveis pela geração do valor da reputação, 
envolvendo os componentes de cálculo da reputação. Os dois últimos se ocupam da propagação deste valor na rede social, envolvendo os componentes da propagação da reputação. Estes componentes são representados por meio dos conceitos Componente de Cálculo da Reputação e Componente de Propagação da Reputação, respectivamente.

A seguir, são descritos tanto os processos reputativos quanto os componentes a eles associados. A ordem de exposição adotada consiste na apresentação (i) dos processos de avaliação e (ii) de manutenção da reputação, (iii) dos componentes de cálculo envolvidos com esses processos, (iv) dos processos de transmissão e recepção da reputação, e finalmente, (v) dos componentes de propagação da reputação. Ao final desta seção, a figura 5.8 apresenta o diagrama de hierarquia desses conceitos.

\subsection{Processo de Avaliação da Reputação}

O conceito Processo de Avaliação da Reputação representa o processo de mensuração de uma reputação. Os tipos de mensuração que podem ser utilizados na avaliação de uma reputação permitem que esta seja (i) avaliada de forma mais genérica, através do nível de estima, como ruim ou ótima, ou (ii) por meio do detalhamento dos aspectos envolvidos na mensuração, identificando tanto os atributos considerados como a relevância dada a cada um deles. Tanto a natureza como a relevância desses aspectos, ou atributos, depende da entidade alvo à qual eles estão relacionados, e variam de acordo com os interesses e valores dos membros de uma rede social (BROMLEY, 1993, p. 26).

Estes tipos de mensurações são representados por meio de dois conceitos: Processo de Avaliação do Conteúdo da Reputação e Processo de Avaliação do Nível de Estima da Reputação. Em ambos os casos, os processos são executados pelas entidades reputativas capazes de desempenhar o papel de avaliador e produzem o valor de avaliação de uma reputação.

O conceito Processo de Avaliação do Conteúdo da Reputação representa o processo de mensuração realizado a partir dos atributos de avaliação e suas respectivas relevâncias, descrevendo o valor de uma reputação em termos desses atributos. O conceito Processo de Avaliação do Nível de Estima da Reputação representa o processo de mensuração que produz um valor de reputação que não pode ser descrito em detalhes, como por exemplo, uma reputação muito boa ou reputação ruim. Ambos os processos podem produzir valores de reputação qualitativos ou quantitativos. 


\subsection{Processo de Manutenção da Reputação}

O conceito Processo de Manutenção da Reputação representa o processo que define qual é o impacto que o resultado da avaliação mais recente da reputação deve causar no valor final da mesma, controlando as alterações que ocorrem no valor da reputação de uma entidade ao longo do tempo. Para tanto, este processo deve considerar tanto a dimensão histórica da reputação como a comparação entre o comportamento real da entidade e aquele esperado dela.

No que concerne à dimensão histórica, ou temporal, alguns autores ${ }^{27}$ consideram que o comportamento mais recente deve ter maior peso na manutenção da reputação de uma entidade alvo em relação ao comportamento mais antigo, visto que a reputação deve refletir com mais fidelidade o comportamento atual que o comportamento passado. Sobre a questão da consistência entre o comportamento real e o esperado, Bromley (1993, p. 216) sugere que qualquer discrepância entre eles pode provocar ajustes no valor da reputação.

Essas duas noções são representadas na Ontologia Funcional de Reputação pelos conceitos Histórico da Reputação e Agregação da Reputação, respectivamente. O conceito Histórico da Reputação define a abrangência temporal da memória das avaliações anteriores considerada na manutenção de uma reputação, assim como a relevância associada às avaliações recentes em detrimento das antigas. Por exemplo, Pedro considera apenas as avaliações feitas no último ano no processo de manutenção da reputação de Maria e atribui àquelas ocorridas nos primeiros seis meses a metade da relevância atribuída àquelas ocorridas nos seis meses mais recentes.

O conceito Agregação da Reputação reflete o impacto no valor da reputação provocado pela discrepância entre o comportamento realmente apresentado pela entidade alvo e o comportamento esperado dela. Por exemplo, o fracasso de Pedro, tido como um ótimo médico, em um determinado procedimento, pode ter maior impacto na sua reputação do que o mesmo fracasso teria na reputação de José, um médico tido como um profissional ainda inexperiente.

O Processo de Manutenção da Reputação produz o valor de final de uma reputação. Zacharia e Maes (2000) e Ferris et al. (2003) sugerem que esse processo deve garantir que o valor final da reputação não cresça infinitamente, pois, caso contrário, as

\footnotetext{
${ }^{27}$ (ZACHARIA e MAES, 2000; FERRIS et al., 2003; MAXIMILIEM e SINGH, 2002a, 2002b; CARTER et al., 2002; FULLAM e BARBER, 2004)
} 
defecções mais recentes da entidade alvo não poderiam afetar de forma significativa uma reputação com valor muito alto.

\subsection{Componente de Cálculo da Reputação}

O conceito Componente de Cálculo da Reputação agrupa os aspectos envolvidos no estabelecimento do valor de uma reputação. Como dito anteriormente, esses componentes são utilizados pelos processos de avaliação e de manutenção da reputação. São eles: Atributo de Avaliação da Reputação, Relevância do Atributo de Avaliação da Reputação, Valor da Avaliação da Reputação, Valor Final da Reputação e Fator de Avaliação da Reputação.

\section{Atributo de Avaliação e sua Relevância}

O conceito Atributo de Avaliação da Reputação representa as características consideradas na avaliação de uma reputação, enquanto o conceito Relevância do Atributo de Avaliação da Reputação representa a importância que uma entidade avaliadora associa a cada atributo. Esses dois conceitos foram definidos a partir da noção de atributo e peso, propostos por Maximilien e Singh (2002b) e descritos na seção 2.2.6, e são utilizados nos processos de avaliação do tipo Processo de Avaliação do Conteúdo da Reputação.

Por exemplo, a avaliação da reputação de um produto pode levar em conta características como o preço, a qualidade e a aparência do mesmo, onde a aparência pode ser mais relevante que os demais. Os atributos considerados na avaliação de uma pessoa podem ser a sua capacitação profissional e facilidade de relacionamento com os colegas, onde o primeiro pode ser mais relevante que o segundo.

\section{Valores da Reputação}

Dois valores são produzidos durante o cálculo de uma reputação: Valor da Avaliação da Reputação e Valor Final da Reputação. O primeiro representa o valor que resulta do Processo de Avaliação de uma reputação. Esse valor pode consistir em uma medida qualitativa, como "boa” ou "má", ou em uma medida quantitativa, como 1 , 2, ou 3. Tal valor pode ser descrito em termos de atributos e seus pesos quando for produzido pelo Processo de Avaliação do Conteúdo da Reputação. Caso contrário, consiste apenas em uma medida simples.

O Valor Final da Reputação representa o valor resultante do Processo de Manutenção da Reputação. Tal como o valor de avaliação da reputação, este valor final pode ser uma medida qualitativa ou quantitativa.

\section{Fator de Avaliação da Reputação}


O conceito Fator de Avaliação da Reputação representa os elementos que, de alguma maneira, influenciam a avaliação de uma reputação, tais como (i) o comportamento do agente alvo (YU e SINGH, 2002, entre outros), (ii) a reputação do agente que transmite a informação (SABATER, 2003; ZACHARIAS e MAES, 2000; KLOS e LA POUTRÉ, 2004) e (iii) as relações sociais existentes entre o agente alvo e o transmissor (SABATER, 2003).

Essas noções são representadas na Ontologia Funcional de Reputação pelos conceitos Comportamento da Entidade Alvo, Reputação da Entidade Transmissora e Relação Social entre Alvo e Transmissor, respectivamente. O conceito Comportamento da Entidade Alvo envolve a noção de norma social (ver seção 5.4.4), dado que a avaliação do comportamento de um agente depende das normas sociais vigentes. Além disso, este fator pode provocar uma confirmação ou uma restrição da responsabilidade do agente (ver seção 5.4.5).

O conceito Relação Social entre Alvo e Transmissor pode ser explicado através do seguinte exemplo: Pedro, no momento em que recebe de José uma informação sobre a reputação de Maria, considera que José e Maria são amigos de longa data antes de aceitar a informação como verdadeira. O seguinte exemplo ilustra o conceito Reputação da Entidade Transmissora como fator de avaliação: Pedro, quando recebe uma informação de José, considera que, dada a má reputação deste, tal informação deve ser considerada apenas parcialmente no seu processo de avaliação.

Cabe ressaltar que a principal diferença entre os conceitos Fator Avaliação da Reputação e Atributo de Avaliação da Reputação consiste em que o último é uma característica específica e inerente à entidade reputativa, por exemplo, a disciplina ou a pontualidade de uma pessoa, enquanto o primeiro é um aspecto mais amplo, normalmente dependente do meio social, como as relações sociais.

A figura 5.7 mostra o diagrama hierárquico dos componentes de cálculo da reputação. 


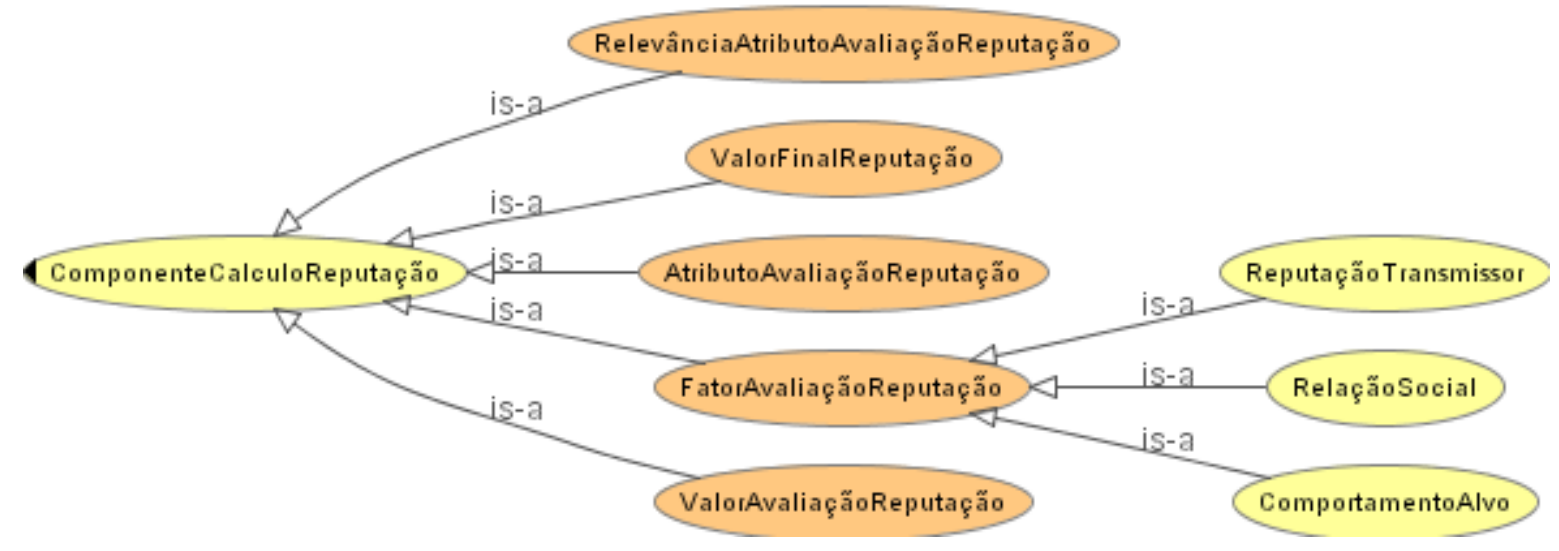

Figura 5.7: Representação do conceito Componente de Cálculo da Reputação

\subsection{Processo de Transmissão e Processo de Recepção da Reputação}

Os conceitos Processo de Transmissão da Reputação e Processo de Recepção da Reputação representam os processos responsáveis pela propagação de uma reputação na rede social. Esses processos foram definidos a partir da noção de transmissão da imagem e reputação proposta por Conte e Paolucci (2002, p. 72), descrita na seção 2.2.2.

O Processo de Transmissão da Reputação, que é executado pelas entidades reputativas que desempenham o papel de transmissor, produz as informações de terceiros, ou informações de segunda mão, que circulam na rede social. O Processo de Recepção da Reputação, que é executado pelas entidades que desempenham o papel de receptor, trata as informações de segunda mão produzidas pelo processo de transmissão. Ambos processos envolvem os componentes de propagação da reputação descritos a seguir.

\subsection{Componente de Propagação da Reputação}

O conceito Componente de Propagação de Reputação representa os elementos envolvidos nos processos de transmissão e recepção de uma reputação na rede social. Tais elementos foram baseados nos aspectos envolvidos na decisão de um agente em transmitir uma reputação, propostos por Conte e Paolucci (2002) e descritos na seção 2.2.2, nomeadamente, “como transmitir”, "por que transmitir” e “o que transmitir”.

Estes elementos são representados na Ontologia Funcional de Reputação por três conceitos: Forma de Propagação, Objetivo da Propagação e Conteúdo da Propagação. O conceito Forma de Propagação define a maneira pela qual a informação sobre a reputação se espalha na rede social, por exemplo, através da cadeia de interações entre os agentes. O conceito Objetivo da Propagação especifica os motivos que levam um agente a propagar uma determinada informação sobre reputação, como, por exemplo, a 
responsabilidade social frente às conseqüências da transmissão. O conceito Conteúdo da Propagação especifica o que a informação propagada compreende, como, por exemplo, o valor real de uma reputação, uma subestimação ou uma superestimação desse valor.

\subsection{Hierarquia e Relacionamentos Envolvendo os Conceitos do Processo}

\section{Reputativo e seus Componentes}

A figura 5.8 mostra o diagrama de hierarquia dos conceitos Componente de Propagação da Reputação, Processo Reputativo e Componente de Cálculo da Reputação.

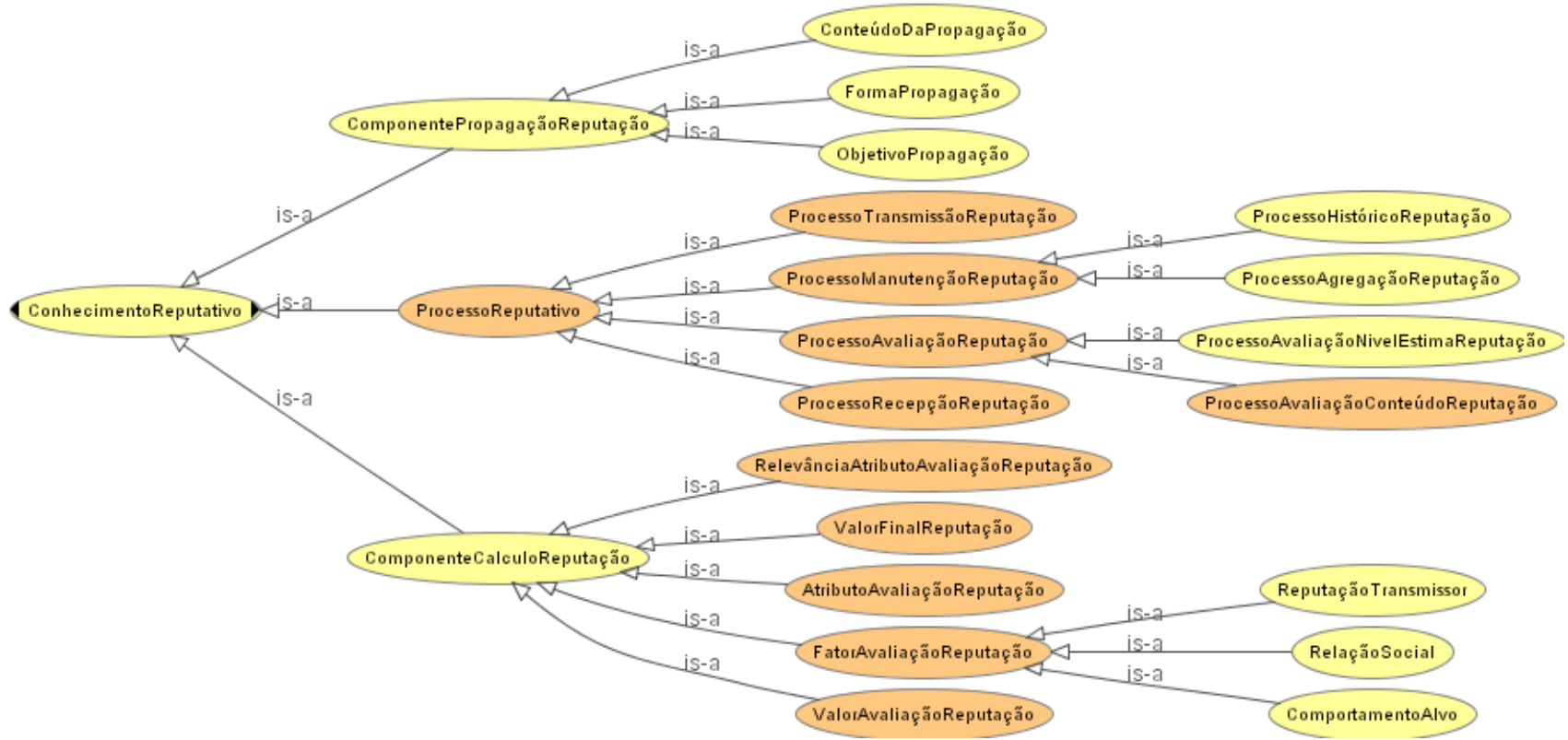

Figura 5.8: Representação dos conceitos Componente de Propagação da Reputação, Processo Reputativo e Componente de Cálculo da Reputação

A tabela 5.4 apresenta os relacionamentos nos quais os processos reputativos e os componentes associados são os sujeitos.

Tabela 5.4: Relacionamentos de Processo Reputativo

\begin{tabular}{|l|l|l|}
\hline \multicolumn{1}{|c|}{ Sujeito do relacionamento } & \multicolumn{1}{|c|}{ Relacionamento } & Objeto do relacionamento \\
\hline Processo Recepção da Reputação & Tem entrada & Informações de Terceiros \\
\cline { 2 - 3 } & É processo reputativo de & Papel de Receptor \\
\cline { 2 - 3 } & Têm componentes em & $\begin{array}{l}\text { Componentes de Propagação } \\
\text { da Reputação }\end{array}$ \\
\hline $\begin{array}{l}\text { Processo Manutenção da } \\
\text { Reputação }\end{array}$ & Produz & Valor Final de Reputação \\
\cline { 2 - 3 } & É processo reputativo de & Papel de Mantenedor \\
\hline Processo Agregação Reputação & Tem entrada & $\begin{array}{l}\text { Valor de Avaliação da } \\
\text { Reputação }\end{array}$ \\
\hline Processo Histórico Reputação & Tem entrada & Tempo \\
\hline Processo Transmissão da & Produz & Informação de Terceiros \\
\hline
\end{tabular}




\begin{tabular}{|c|c|c|}
\hline Sujeito do relacionamento & Relacionamento & Objeto do relacionamento \\
\hline \multirow[t]{2}{*}{ Reputação } & É processo reputativo de & Papel de Transmissor \\
\hline & Têm componentes em & $\begin{array}{l}\text { Componente de Propagação da } \\
\text { Reputação }\end{array}$ \\
\hline \multirow[t]{3}{*}{ Processo Avaliação da Reputação } & Tem entrada & Fator de Avaliação \\
\hline & Produz & $\begin{array}{l}\text { Valor de Avaliação da } \\
\text { Reputação }\end{array}$ \\
\hline & É processo reputativo de & Papel de Avaliador \\
\hline $\begin{array}{l}\text { Processo Avaliação Conteúdo } \\
\text { Reputação }\end{array}$ & Tem detalhe em & Atributo Avaliação Reputação \\
\hline \multirow[t]{2}{*}{ Atributo Avaliação Reputação } & Tem relevância & $\begin{array}{l}\text { Relevância Atributo Avaliação } \\
\text { Reputação }\end{array}$ \\
\hline & É detalhe de & $\begin{array}{l}\text { Processo Avaliação Conteúdo } \\
\text { Reputação }\end{array}$ \\
\hline $\begin{array}{l}\text { Relevância Atributo Avaliação } \\
\text { Reputação }\end{array}$ & É relevância de & Atributo Avaliação Reputação \\
\hline \multirow[t]{2}{*}{ Valor Avaliação Reputação } & Ë produzido por & Processo Avaliação Reputação \\
\hline & Tem detalhe em & Atributo Avaliação Reputação \\
\hline Valor Final Reputação & É produzido por & $\begin{array}{l}\text { Processo Manutenção } \\
\text { Reputação }\end{array}$ \\
\hline Fator de Avaliação & É entrada para & Processo Avaliação Reputação \\
\hline \multirow[t]{2}{*}{ Comportamento Alvo } & Ë classificado por & Norma Social \\
\hline & $\begin{array}{l}\text { Tem responsabilidade } \\
\text { confirmada por }\end{array}$ & Atribuição de Causalidade \\
\hline
\end{tabular}

\subsubsection{Visão Geral do Conhecimento Reputativo}

A figura 5.9 apresenta todos os conceitos que fazem parte da categoria Conhecimento Reputativo. 


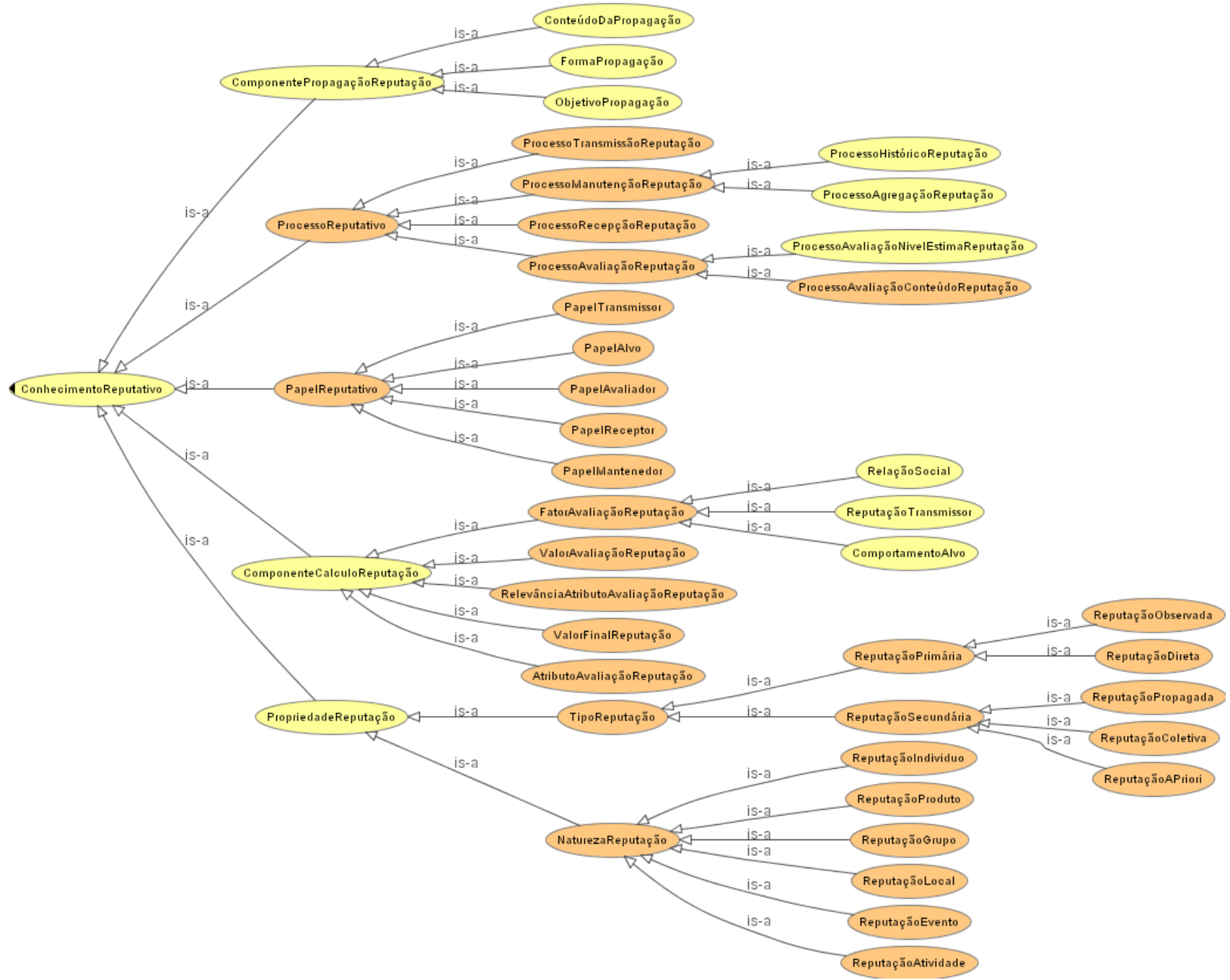

Figura 5.9: Representação dos conceitos da categoria Conhecimento Reputativo

\subsubsection{Conhecimento de Senso Comum}

A categoria Conhecimento de Senso Comum foi emprestada da Ontologia Funcional do Direito (VALENTE, 1995) e adaptada para especificar os elementos do senso comum envolvidos na descrição do Conhecimento de Reputação, principalmente na sua subcategoria Conhecimento Reputativo. Por exemplo, os papéis reputativos aplicam-se às entidades do mundo real, enquanto os tipos de reputação envolvem as fontes de informação do mundo real.

Cabe ressaltar que uma definição exaustiva das características desses elementos do senso comum não faz parte do escopo dessa ontologia. A função deste conhecimento é especificar apenas aquelas características que são relevantes para a construção do Conhecimento de Reputação. 
O Conhecimento de Senso Comum é composto por 17 conceitos, organizados em duas hierarquias, Fonte de Informação e Entidade Reputativa, e do conceito Tempo. Em relação à Ontologia Funcional do Direito, o conceito Entidade Reputativa corresponde ao Indivíduo Jurídico e Tempo ao conceito homônimo, enquanto Fonte de Informação consiste em um conceito original da Ontologia Funcional de Reputação. Estes conceitos são descritos a seguir.

\subsubsection{Fonte de Informação}

O conceito Fonte de Informação representa os elementos que podem ser fonte de informação de uma reputação: Experiência Direta, Observação, Herança de Grupo, Informação Recebida de Terceiro e Preconceito.

O conceito Experiência Direta representa a fonte que consiste nas informações adquiridas através da interação direta, enquanto o conceito Observação consiste nas informações adquiridas por meio da observação dessas interações.

O conceito Informação Recebida de Terceiro representa a fonte de informação que consiste nas informações transmitidas na rede social.

O conceito Preconceito representa a informação baseada em estereótipos e preconceitos sociais. Por exemplo, preconceitos e estereótipos associados à etnia, gênero ou nacionalidade.

O conceito Herança de Grupo representa a fonte de informação que consiste nas características do grupo ao qual o agente pertence que são herdadas por ele. Por exemplo, um funcionário pode herdar as características associadas à firma na qual trabalha. Este conceito poderia ser considerado um subconceito de Preconceito, mas, como discutido na seção 5.4.1.1.2, esta solução não foi adotada visto que este último tem uma conotação negativa na maior parte dos casos, o que não acontece com Herança de Grupo.

\subsubsection{Entidade Reputativa}

O conceito Entidade Reputativa foi definido a partir do conceito Elemento Individuo da Ontologia Funcional do Direito (ver seção 4.2.1) e representa as entidades relevantes para o Conhecimento de Reputação. Tais entidades são aquelas capazes de desempenhar pelo menos um papel reputativo, e dessa forma serem envolvidas nos processos de avaliação, manutenção, transmissão e recepção da reputação. Da mesma forma que um Elemento Individuo, as entidades reputativas podem ser classificadas como agentes ou não agentes. 
O conceito Agente amplia a noção do seu homônimo na Ontologia Funcional do Direito, visto que representa qualquer entidade capaz de agir por si mesma, e não apenas aquelas que podem ser responsabilizadas juridicamente pelas próprias ações. Assim, este conceito representa as entidades reputativas que, além de desempenhar o papel de alvo da reputação, também são capazes de executar os processos reputativos, tais como os indivíduos (pessoas e agentes de software) e grupos de indivíduos.

O conceito Não Agente representa aquelas entidades desprovidas da capacidade de executar processos reputativos e, portanto, limitadas a serem apenas o alvo da reputação, tal como um objeto, um local ou um serviço. Em relação ao seu homônimo na Ontologia Funcional do Direito, o conceito foi (i) estendido, a fim de representar também as entidades que não são objetos, tal como uma atividade, e (ii) restringido de modo a representar apenas as entidades que não são capazes de $\operatorname{agir}^{28}$.

O conceito Tempo representa a sucessão dos anos, dias e horas que envolvem a noção de presente, passado e futuro, e corresponde ao seu homônimo na Ontologia Funcional do Direito.

\subsubsection{Relacionamentos envolvendo os conceitos do Conhecimento de Senso}

\section{Comum}

A figura 5.10 mostra o diagrama da hierarquia entre os conceitos que compõem o Conhecimento de Senso Comum.

\footnotetext{
${ }^{28}$ Na Ontologia Funcional do Direito, o conceito Não Agente representa os elementos que não podem ser responsabilizados juridicamente por seus atos, mesmo sendo capazes de agir (ver seção 4.2.1).
} 


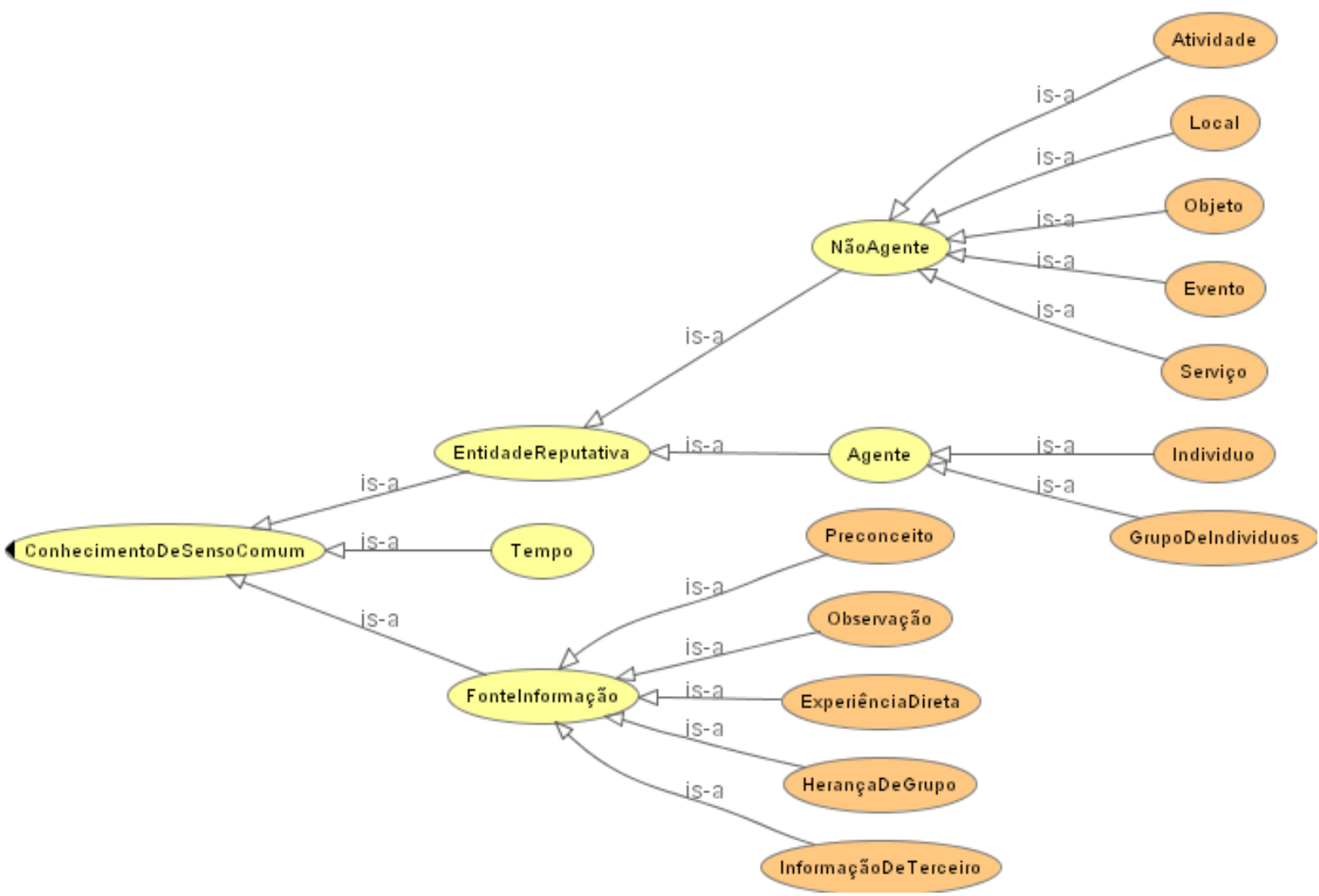

Figura 5.10: Representação dos conceitos da categoria Conhecimento de Senso Comum

A tabela 5.5 apresenta os relacionamentos definidos entre os conceitos do Conhecimento de Senso Comum e os conceitos do Conhecimento de Reputação, nos quais os primeiros são sujeito do relacionamento.

Tabela 5.5: Relacionamentos de Conhecimento de Senso Comum

\begin{tabular}{|l|l|l|}
\hline \multicolumn{1}{|c|}{ Sujeito do relacionamento } & Nome do Relacionamento & Objeto do relacionamento \\
\hline Agente & Tem papel reputativo & Papel Reputativo \\
\hline Grupo de Individuo & Tem natureza de reputação & Reputação de Grupo \\
\hline Indivíduo & Tem natureza de reputação & Reputção Individual \\
\hline Não Agente & Tem papel reputativo & Papel Alvo \\
\hline Serviço & Tem natureza de reputação & Reputação de Produto \\
\hline Local & Tem natureza de reputação & Reputação de Local \\
\hline Atividade & Tem natureza de reputação & Reputação de Atividade \\
\hline Objeto & Tem natureza de reputação & Reputação de Produto \\
\hline Evento & Tem natureza de reputção & Reputção de Evento \\
\hline Preconceito & É fonte de informação de & Reputação a Priori \\
\hline Experiência Direta & É fonte de informação de & Reputação Direta \\
\hline Herança de Grupo & É fonte de informação de & Reputação Coletiva \\
\hline Observação & É fonte de informação de & Reputação Observada \\
\hline Informação de Terceiro & É fonte de informação de & Reputação Propagada \\
\hline Tempo & É entrada para & Histórico da Reputação \\
\hline
\end{tabular}




\subsubsection{Conhecimento do Mundo}

A categoria Conhecimento do Mundo foi emprestada da Ontologia Funcional do Direito (VALENTE, 1995) e representa os acontecimentos do mundo que são relevantes para o Conhecimento de Reputação.

Da mesma forma que em (VALENTE, 1995), na Ontologia Funcional de Reputação esta categoria desempenha o papel de interface entre o mundo real e o mundo reputativo, definindo um modelo do primeiro de forma a expressar, por um lado, as categorias típicas do segundo, e, por outro lado, os conceitos advindos do conhecimento do senso comum, encapsulando essas noções para que possam ser tratadas como noções reputativas. Assim, esse conhecimento descreve, de forma abstrata, as situações e comportamentos que podem ocorrer nos acontecimentos do mundo real.

O Conhecimento do Mundo envolve quatro conceitos principais: Conceito Reputativo, Relação Reputativa, Caso e Circunstância. Em relação à Ontologia Funcional do Direito (ver seção 3.5.2), o primeiro corresponde ao Conceito Jurídico (legal concept), o segundo corresponde à Relação Jurídica (legal relation) e os conceitos Caso e Circunstância correspondem aos seus homônimos. Os demais conceitos do Conhecimento Do Mundo propostos por essa ontologia, nomeadamente, Caso Genérico e Condição, não fazem parte da Ontologia Funcional de Reputação, visto que a abstração fornecida por eles não foi necessária para a especificação dos demais conceitos desta ontologia.

Da forma análoga à Ontologia Funcional do Direito, o Conceito Reputativo e a Relação Reputativa fornecem um arcabouço que encapsula tanto os elementos do senso comum quanto o relacionamento existente entre eles. Assim, o primeiro representa os conceitos do Conhecimento de Senso Comum, tais como pessoas, organizações, objetos, locais e fontes de informação, enquanto o segundo representa as suas relações. Por exemplo, uma relação entre o indivíduo João (exemplo do conceito Individuo) e a atividade Fumar (exemplo do conceito Atividade).

O conceito Circunstância representa a situação na qual o acontecimento ocorreu, enquanto o conceito Caso representa o comportamento de uma entidade reputativa em tal acontecimento. Por exemplo, o acontecimento "aluno fuma em uma sala de aula quando a sala está vazia” pode ser descrito pelo Caso “aluno fuma na sala de aula” e pela Circunstância "sala de aula vazia”.

A figura 5.11 mostra os conceitos da categoria Conhecimento do Mundo. 


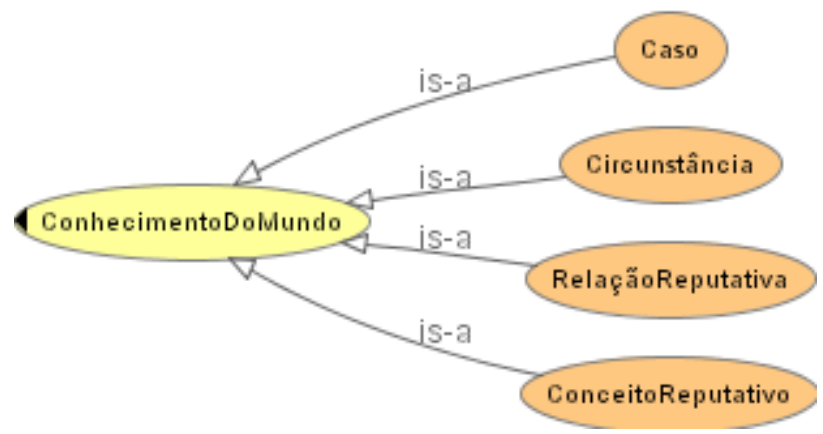

Figura 5.11: Representação dos conceitos da categoria Conhecimento do Mundo

A tabela 5.6 complementa a definição dos conceitos do Conhecimento do Mundo mostrando os relacionamentos destes conceitos com os demais conceitos da ontologia.

Tabela 5.6: Relacionamentos de Conhecimento do Mundo

\begin{tabular}{|l|l|l|}
\hline Sujeito do relacionamento & \multicolumn{1}{|c|}{ Relacionamento } & Objeto do relacionamento \\
\hline Relação Reputativa & Tem Relacionamento para & $\begin{array}{l}\text { Conhecimento de Senso } \\
\text { Comum }\end{array}$ \\
\hline Conceito Reputativo & Tem definição para & $\begin{array}{l}\text { Conhecimento de Senso } \\
\text { Comum }\end{array}$ \\
\hline Caso & $\begin{array}{l}\text { É descrição de } \\
\text { comportamento de }\end{array}$ & Entidade Reputativa \\
\cline { 2 - 3 } & É classificado por & Status Normativo \\
\cline { 2 - 3 } & Tem correspondência com & Norma Social \\
\hline Circunstância & Tem impacto em & Atribuição de Causalidade \\
\cline { 2 - 3 } & Ë situação para & Caso \\
\hline
\end{tabular}

\subsubsection{Conhecimento Normativo}

A categoria Conhecimento Normativo foi emprestada da Ontologia Funcional do Direito (VALENTE, 1995), onde representa as noções associadas às normas jurídicas, e adaptada para representar as noções associadas às normas sociais. A sua principal função é classificar o comportamento real como adequado, não adequado ou neutro, segundo as normas sociais vigentes. Essa classificação depende primeiramente da definição dessas normas sociais, e em seguida da comparação do comportamento real com as normas.

O Conhecimento Normativo envolve dois conceitos principais: Norma Social e Status Normativo. O primeiro corresponde ao conceito Norma Primária e o segundo ao conceito homônimo da Ontologia Funcional do Direito (ver seção 4.2.1). De forma análoga a tal ontologia, a aplicação de uma norma social na Ontologia Funcional de Reputação consiste na comparação do comportamento no mundo real, representado pelo Caso, com aquele do mundo ideal, representado pela Norma Social, classificando o Caso por meio de um Status Normativo. 


\subsubsection{Norma Social}

O conceito Norma Social representa a descrição das normas que prescrevem os comportamentos em uma sociedade. Essas normas podem ser positivas, quando prescrevem comportamentos válidos, ou negativas, quando prescrevem comportamentos inválidos. Os conceitos Norma Social Positiva e Norma Social Negativa representam, respectivamente, essas duas noções. A norma "é válido ser pontual nos compromissos" é um exemplo de norma social positiva, enquanto a norma "é inválido fumar em local fechado” é um exemplo de norma social negativa.

Cabe ressaltar que não é função do Conhecimento Normativo decidir se um comportamento inválido, portanto associado a uma norma negativa, deve ter maior influência na reputação de um agente que um comportamento válido. A definição do impacto do comportamento do agente na sua reputação é função do Conhecimento Reputativo, responsável pela especificação da sanção ${ }^{29}$ que deve ser aplicada ao agente.

\subsubsection{Status Normativo}

O conceito Status Normativo representa a classificação normativa de um comportamento real após ser comparado às normas sociais. Os conceitos Status Normativo Adequado, Status Normativo Inadequado e Status Normativo Neutro representam os três tipos possíveis de status normativo. O primeiro está associado às normas sociais positivas e classifica os comportamentos reais como adequados. O segundo está associado às normas sociais negativas e classifica os comportamentos reais como inadequados. Finalmente, o Status Normativo Neutro classifica os comportamentos reais que não são prescritos pelas normas sociais. Por exemplo, o comportamento real “João fuma em lugar fechado" corresponde à norma social negativa “é inválido fumar em local fechado”, sendo classificado com o Status Normativo Inadequado. O comportamento "João é pontual nos seus compromissos” que corresponde à norma "é válido ser pontual nos compromissos” é classificado com o Status Normativo Adequado. Por fim, o comportamento "João fuma no pátio” não corresponde a nenhuma norma social vigente, já que um pátio não é um lugar fechado, e assim é classificado com o Status Normativo Neutro.

\footnotetext{
${ }^{29}$ Tal sanção é resultado do Processo de Avaliação da Reputação. O impacto do comportamento do agente no valor da sua reputação é representado pelo conceito Fator de Avaliação da Reputação, e seu subconceito Comportamento da Entidade Alvo (ver seção 5.4.1.3).
} 
A principal diferença entre o Conhecimento Normativo aqui definido e aquele proposto pela Ontologia Funcional do Direito consiste na utilização das noções de adequado e inadequado, ao invés de permitido e proibido, para classificar os comportamentos associados às normas sociais positivas e negativas, respectivamente. Essas noções foram consideradas mais apropriadas que as noções de permitido e proibido visto que a Ontologia Funcional de Reputação representa o comportamento real de acordo com uma perspectiva social e não jurídica, e o comportamento prescrito por uma norma social nem sempre é juridicamente permitido ou proibido. Por exemplo: o comportamento “João fuma em local fechado” pode ser considerado socialmente inadequado, mas não é juridicamente proibido; o comportamento “João é pontual em seus compromissos” não é objeto de regulamentação jurídica, mas pode ser associado a uma norma social positiva, tendo nesse caso um status normativo adequado.

\subsubsection{Relacionamentos Envolvendo os Conceitos do Conhecimento}

\section{Normativo}

A figura 5.12 mostra o diagrama da hierarquia entre os conceitos do Conhecimento Normativo.

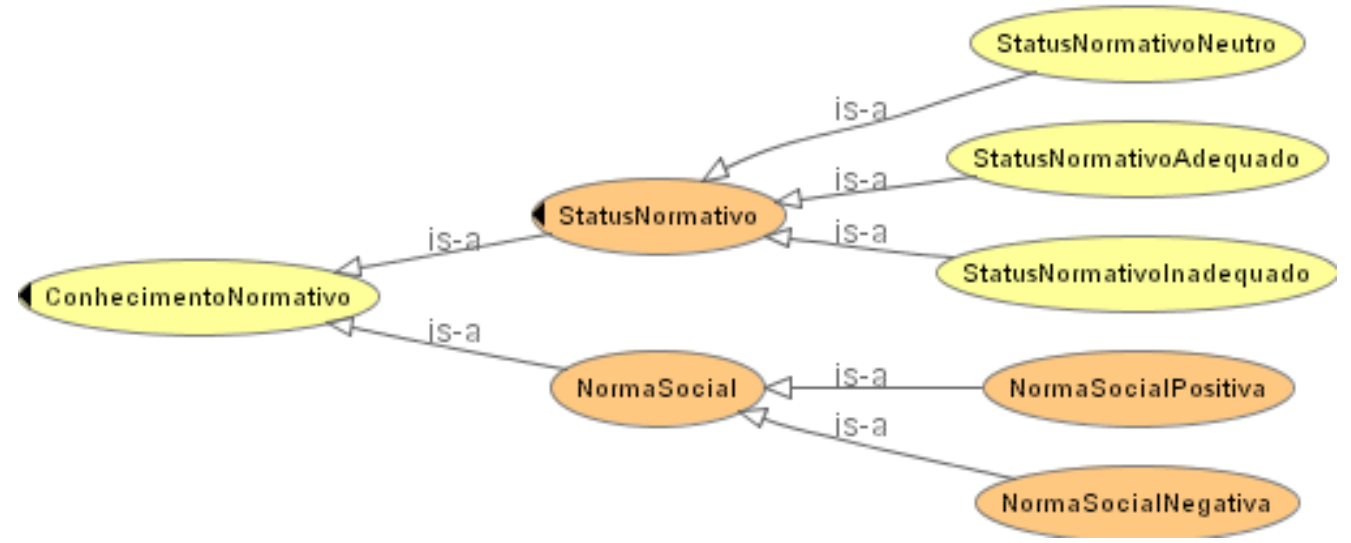

Figura 5.12: Representação dos conceitos da categoria Conhecimento Normativo

A tabela 5.7 mostra os relacionamentos que envolvem os conceitos do Conhecimento Normativo como sujeitos dos mesmos.

Tabela 5.7: Relacionamentos de Conhecimento Normativo

\begin{tabular}{|l|l|l|}
\hline Sujeito do relacionamento & \multicolumn{1}{|c|}{ Relacionamento } & \multicolumn{1}{|c|}{ Objeto do relacionamento } \\
\hline Status Normativo & Classifica & Caso \\
\hline Norma Social & É união de & $\begin{array}{l}\text { Norma Social Positiva e Norma Social } \\
\text { Negativa }\end{array}$ \\
\hline Norma Social Positiva & Tem status normativo & Status Normativo Adequado \\
\hline
\end{tabular}




\begin{tabular}{|l|c|c|}
\hline Sujeito do relacionamento & Relacionamento & Objeto do relacionamento \\
\hline Norma Social Negativa & Tem status normativo & Status Normativo Inadequado \\
\hline
\end{tabular}

\subsubsection{Conhecimento de Responsabilidade}

A categoria Conhecimento de Responsabilidade foi emprestada da Ontologia Funcional do Direito (VALENTE, 1995) e estendida para representar os conceitos relacionados aos mecanismos de atribuição de causalidade inerentes à noção de reputação (BROMLEY, 1993, p.37). Sua função é atribuir uma causa ao comportamento apresentado pelo agente, definindo se tal comportamento pode ser considerado de inteira responsabilidade do agente ou se, face às circunstâncias nas quais o comportamento ocorreu, a sua responsabilidade deve ser atenuada.

O Conhecimento de Responsabilidade é composto por seis conceitos, dos quais os principais são: Atribuição de Causalidade, Efeito Ator-Observador, Confirmação de Responsabilidade e Restrição de Responsabilidade. Os dois últimos consistem em uma reutilização dos conceitos já existentes na Ontologia Funcional do Direito, enquanto os dois primeiros foram criados na Ontologia Funcional de Reputação.

\subsubsection{Atribuição de Causalidade}

O conceito Atribuição De Causalidade representa o termo usado em cognição social para se referir às causas pelas quais as ações são interpretadas em termos das características pessoais e das circunstâncias externas, de forma a prover uma explicação causal dos comportamentos. Os processos de atribuição são parte da nossa inclinação natural de impor um padrão de significado aos fatos que são observados. Em relação à reputação, um dos efeitos da atribuição é emprestar consistência e coerência aos comportamentos (BROMLEY, 1993, p.37).

Um comportamento tem causa interna quando é interpretado como dependendo exclusivamente do agente, por exemplo, a motivação e a capacidade do agente. Um comportamento tem causa externa quando se considera que depende das circunstâncias nas quais ocorreu, por exemplo, as oportunidades oferecidas ou as ameaças sofridas pelo agente. Conforme visto na seção 2.3.3, Castelfranchi et al. (2003a) enfatizam a importância da atribuição de causalidade em modelos cognitivos de confiança, visto que essa atribuição pode guiar a definição de estratégias tanto para formar quanto para aumentar a confiança. 
Os conceitos Causa Interna e Causa Externa foram definidos na Ontologia Funcional de Reputação para representar estas noções.

\subsubsection{Efeito Ator Observador}

A percepção da causalidade, interna ou externa, é afetada pelo chamado efeito atorobservador, nome dado à tendência de atribuir causas internas ao comportamento dos outros e de atribuir causas externas ao próprio comportamento, o que provoca um erro fundamental de atribuição (BROMLEY, 1993, p. 38). O conceito Efeito Ator Observador foi criado na Ontologia Funcional de Reputação para representar tal efeito.

Bromley (1993) salienta que esse efeito tem maior possibilidade de afetar a percepção sobre pessoas que se conhece pouco e menor possibilidade de afetar a percepção sobre as pessoas que se conhece bem, pois, neste caso, pode-se avaliar melhor a forma pela qual uma determinada situação afeta o comportamento dessas pessoas.

\subsubsection{Confirmação e Restrição de Responsabilidade}

O conceito Confirmação de Responsabilidade especifica que uma determinada entidade reputativa deve ser considerada responsável em um dado caso, visto que este ocorreu sob condições interpretadas como dependentes apenas de causas internas a essa entidade. O conceito Restrição de Responsabilidade especifica que uma entidade reputativa não deve ser responsabilizada por um caso específico, dado que este ocorreu em circunstâncias que foram interpretadas como dependentes de causas externas.

Uma vez que a responsabilidade de um agente em um caso é confirmada ou restringida, o Conhecimento Reputativo, descrito na seção 5.4.1, pode exercer sua função, definindo a recompensa ou a punição de um agente com uma boa reputação ou com uma má reputação, respectivamente. Por exemplo, Pedro chegou atrasado ao trabalho porque acordou muito tarde. O Conhecimento de Responsabilidade, por meio da Atribuição de Causalidade, atribui uma Causa Interna ao comportamento "chegar atrasado por ter dormido muito", confirmando a responsabilidade de Pedro no caso. O Conhecimento Reputativo, então, define que este comportamento deve ser punido com uma má reputação. Se a causa do atraso de Pedro tivesse sido outra, por exemplo, Pedro chegou atrasado porque seu filho estava doente, a sua reputação seria diferente. Nesse caso, o Conhecimento de Responsabilidade atribuiria uma Causa Externa ao comportamento de Pedro, restringindo a sua responsabilidade. O Conhecimento Reputativo então consideraria que este comportamento não deve ser punido com uma má reputação. 


\subsubsection{Relacionamento Envolvendo os Conceitos do Conhecimento de}

\section{Responsabilidade}

A figura 5.13 mostra o diagrama da hierarquia dos conceitos da categoria Conhecimento de Responsabilidade.

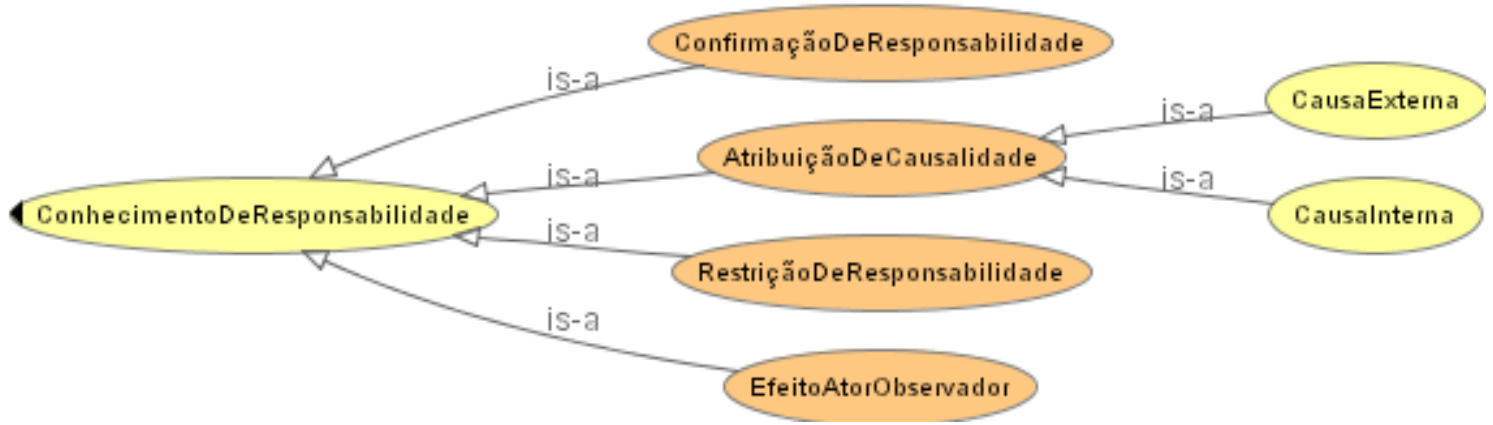

Figura 5.13: Representação dos conceitos da categoria Conhecimento De Responsabilidade

A tabela 5.8 mostra os relacionamentos que têm os conceitos do Conhecimento de Responsabilidade como o sujeito.

Tabela 5.8: Relacionamentos de Conhecimento de Responsabilidade

\begin{tabular}{|l|l|l|}
\hline \multicolumn{1}{|c|}{ Sujeito do relacionamento } & \multicolumn{1}{|c|}{ Relacionamento } & Objeto do relacionamento \\
\hline Atribuição de Causalidade & É atribuição de & Caso \\
\cline { 2 - 3 } & Ë afetada por & Efeito Ator Observador \\
\cline { 2 - 3 } & É influenciada por & Circunstância \\
\hline Causa Externa & Provoca & Restrição de Responsabilidade \\
\hline Causa Interna & Provoca & $\begin{array}{l}\text { Confirmação de } \\
\text { Responsabilidade }\end{array}$ \\
\hline Confirmação de Responsabilidade & É provocada por & Causa Interna \\
\hline Restrição de Responsabilidade & Ë provocada por & Causa Externa \\
\hline Efeito Ator Observador & Tem efeito sobre & Atribuição de Causalidade \\
\hline
\end{tabular}

\subsubsection{Relacionamento entre as Categorias da Ontologia Funcional}

\section{de Reputação}

A figura 5.14 apresenta uma visão detalhada do relacionamento entre os principais conceitos que compõem as cinco categorias de conhecimento da Ontologia Funcional de Reputação. Esta figura corresponde a uma versão detalhada da figura 5.1. 


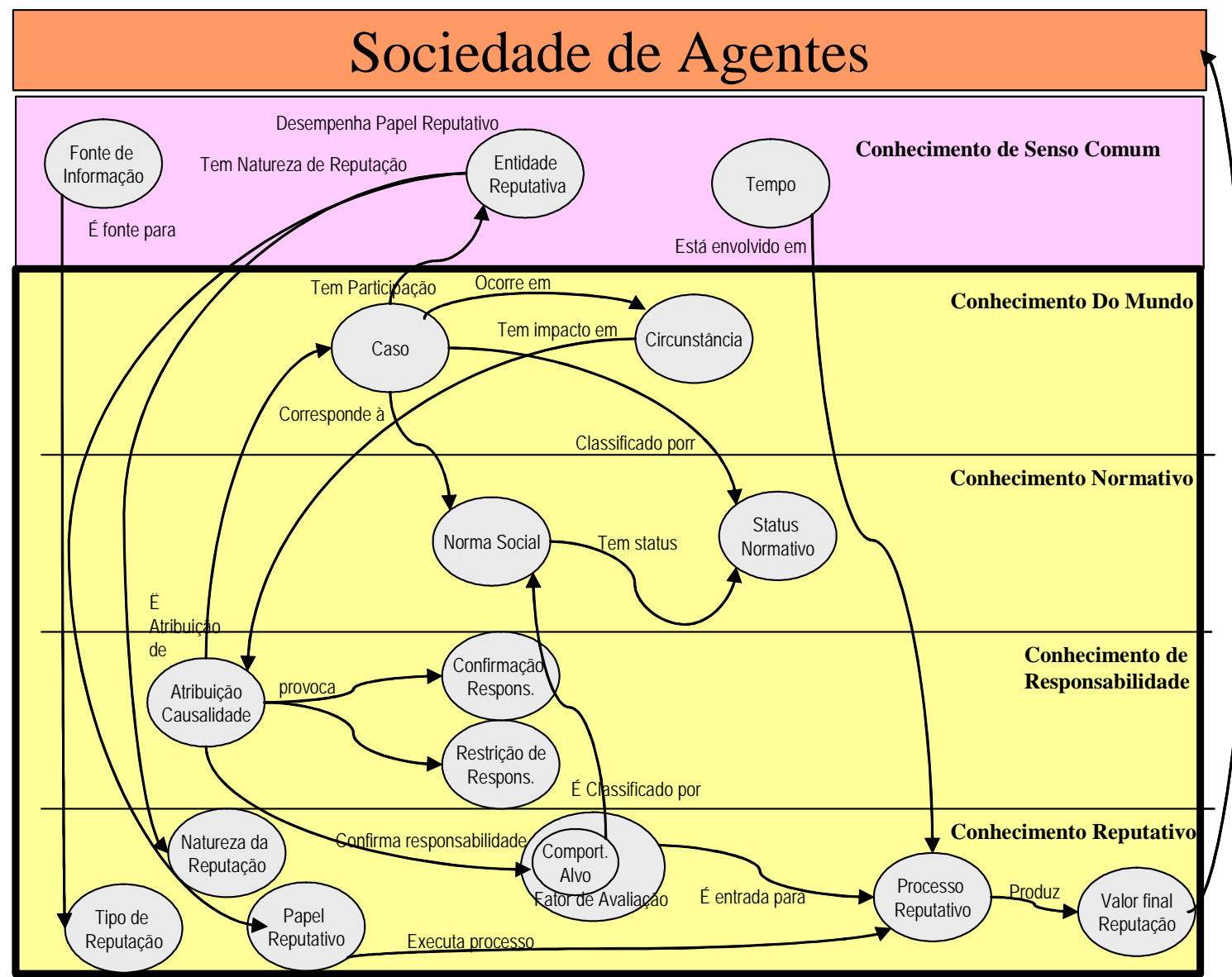

Figura 5.14: Principais conceitos e relacionamentos da Ontologia Funcional de Reputação

Para efeito de ilustração, considere-se novamente o exemplo do atropelamento descrito na seção 4.2.2: um jovem, João, provoca um atropelamento sobre uma faixa de pedestres e não socorre a vítima, Maria, fugindo do local do acidente. Um pedestre, Joaquim, presenciou o acidente e, por coincidência, é colega de trabalho de João.

Neste acontecimento, as entidades reputativas são João, Maria e Joaquim, e a fonte de informação é a observação que Joaquim, como testemunha do acidente, fez da interação entre João e Maria. O caso pode ser descrito como: João atropela Maria e foge do local do acidente. As circunstâncias seriam: João dirige em alta velocidade em local de velocidade controlada e não respeita a faixa de pedestres.

Na sociedade deste exemplo, existe a seguinte norma social: é inadequado abandonar o local do acidente sem prestar socorro à vítima. Graças ao seu Conhecimento Normativo, Joaquim é capaz de classificar o comportamento de João com um status normativo, por meio da correspondência existente entre o caso de atropelamento e a norma social citada. Portanto, aos olhos de Joaquim, o comportamento de João foi inadequado. Além disso, Joaquim conhece João há algum tempo e sabe que este tem o hábito de andar em alta velocidade. Portanto, Joaquim considera que o comportamento de João é devido a 
uma causa interna, o que o leva a confirmar a responsabilidade de João neste acontecimento.

A partir destas informações, comportamento inadequado, gerado pelo Conhecimento Normativo, e confirmação de responsabilidade, produzido pelo Conhecimento de Responsabilidade, Joaquim está apto a avaliar a reputação de João. Assim, Joaquim avalia uma reputação individual, do João, a partir da observação do comportamento deste durante o atropelamento. Por meio de seu processo de avaliação de reputação Joaquim considera os seguintes atributos de João - indivíduo pouco responsável e motorista descuidado - produzindo uma má reputação. Entretanto, anteriormente Joaquim havia atribuído uma boa reputação a João, visto ser este um colega de trabalho atencioso e pontual nos seus compromissos. Graças ao processo de manutenção da reputação, Joaquim é capaz de agregar o novo valor de reputação ao anterior, produzindo a reputação final - reputação duvidosa - mesmo sabendo que o atropelamento não provocou ferimentos graves em Maria, apenas arranhões superficiais.

No dia seguinte, de volta ao trabalho, Joaquim decide contar a Pedro o ocorrido, pois Pedro é seu amigo e costuma pegar carona com João. Desse modo, Joaquim desempenha os papéis de avaliador e mantenedor, além do papel de transmissor da reputação, tomando a decisão de transmiti-la devido a sua amizade com Pedro, enquanto esse desempenha o papel de receptor. Finalmente, a partir das informações recebidas, Pedro é então capaz de atualizar a reputação de João, graças ao seu sistema reputativo.

\subsection{Codificação da Ontologia Funcional de Reputação}

Esta seção descreve a atividade de codificação das categorias, conceitos e relacionamentos da Ontologia Funcional de Reputação em uma linguagem formal. Esta atividade foi realizada em dois passos, de acordo com a estratégia de desenvolvimento adotada. Primeiramente, ocorreu a escolha da linguagem e ferramentas utilizadas, a OWL DL (DEAN e SCHREIBER, 2004), o editor de ontologias Protégé (GENNARI et al., 2003) versão 2.1.2 e o motor de inferência RACER (HAARSLEV e MOLLER, 2003) versão 1.7.23, descritos nas seções 3.3.7, 3.4.5 e 3.5.4, respectivamente. Em seguida, foi realizada a implementação da ontologia em OWL DL. 


\subsubsection{Linguagem e Ferramentas Utilizadas na Codificação}

A linguagem OWL DL foi utilizada na implementação da Ontologia Funcional de Reputação devido às seguintes características:

- Contém as primitivas para a representação das categorias, conceitos e relacionamentos da ontologia, quais sejam, as classes, subclasses e propriedades. Além disso, estas primitivas oferecem a expressividade necessária, tais como a representação de classes disjuntas e a definição de classes a partir da combinação de outras classes (ver seção 3.3.7.2);

- Permite inferência lógica realizada por mecanismo de raciocínio automático que implementa um algoritmo correto e completo para raciocínio com classes;

- É amplamente utilizada no meio acadêmico, inclusive no Brasil;

- Permite a utilização da ontologia desenvolvida em ambientes Web;

- Pode ser gerado por meio de um editor de ontologias, o Protégé.

A principal desvantagem da linguagem OWL DL, a sintaxe complexa que dificulta a implementação e manutenção da ontologia, foi mitigada por meio da utilização de um editor, o Protégé, e de um motor de inferência, o RACER. O primeiro gerou automaticamente o código em OWL DL a partir de uma interface gráfica, enquanto o segundo permitiu checar a consistência da ontologia durante todo o processo de seu desenvolvimento.

Além de oferecer um plug-in para a linguagem OWL, o Protégé foi escolhido como ambiente de desenvolvimento pelas seguintes razões:

- É de uso livre e amplamente utilizado pela comunidade acadêmica;

- Oferece material de apoio de ótima qualidade, tal como o tutorial desenvolvido por Horridge (2004) e as listas de discussão na Internet ${ }^{30}$;

- Possui diversos plug-ins, que oferecem serviços como a representação gráfica da ontologia e sua exportação para outros ambientes.

A escolha do RACER como motor de inferência deveu-se à facilidade de uso junto com o Protégé e às características próprias do produto, tais como a rapidez de execução, a utilização de algoritmo de inferência completo e correto, e a oferta de diversas formas de interface, tanto baseadas em TCP como aquela especificada pelo Grupo de Implementação

\footnotetext{
${ }^{30}$ http://news.gmane.org/gmane.comp.misc.ontology.protege.owl.
} 
de Lógica Descritiva (DIG - Description Logic Implementation Group) (BECHHOFER et al., 2003).

\subsubsection{Implementação da Ontologia Funcional de Reputação em}

\section{OWL DL}

A codificação da Ontologia Funcional de Reputação em OWL DL consistiu na transformação da descrição de seus elementos (ver seção 5.4) de linguagem natural para linguagem formal. Assim, as categorias, conceitos e relacionamentos da ontologia foram representados formalmente por meio das classes, subclasses e propriedades da OWL DL. O Anexo A deste texto mostra de que forma a codificação da ontologia em OWL DL, que consiste em um documento em OWL DL, está disponibilizada para leitura.

A língua inglesa foi utilizada na definição dos nomes e comentários de classes e propriedades, de forma que a ontologia possa ser discutida e utilizada em meios acadêmicos internacionais. A título de exemplo, o fragmento em OWL DL abaixo define a classe Individuo (Individual), que é subclasse de Agente (Agent), tem a Reputação Individual (Individual Reputation) como Natureza de Reputação (ReputationNature) e é disjunta da classe Grupo de Indivíduos (GroupOfIndividual) (ver seção 5.4.2.2):

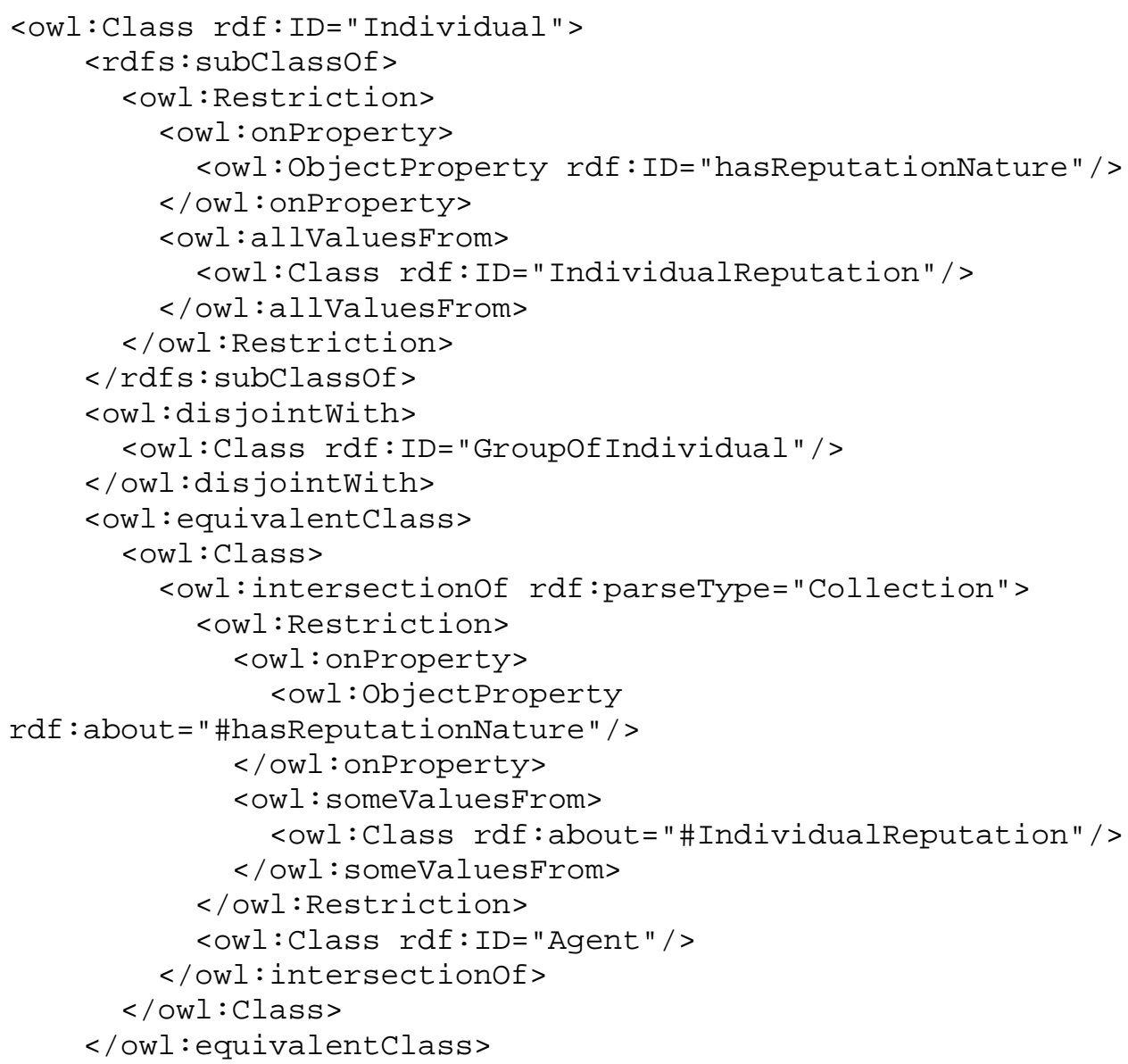


$<$ rdfs: comment

rdf : datatype="http: //Www.w3 .org/2001/XMLSchema\#string"

$>$ An individual is a single agent. For example: a person, a

robot, a software agent.

$<$ owl:Class $>$

Algumas técnicas de programação foram adotadas na implementação da ontologia em OWL DL, tais como:

- Utilizar um padrão para a definição de nomes de classes e propriedades: concatenação de palavras com as iniciais em letras maiúsculas, sem o uso de conectores como hífen ou ponto. Por exemplo: SocialNorm (norma social), ReputationEvaluationAttribute (atributo de avaliação da reputação) (HORRIDGE, 2004, p. 28);

- Utilizar um padrão para a definição de nome de propriedades. Salvo exceções, os nomes de propriedades são prefixados com os termos has (tem) e is (é), de maneira a associar semânticamente uma propriedade e a sua inversa. Por exemplo: hasReputationNature (tem natureza de reputação) e isReputationNatureOf (é natureza de reputação de). Esta convenção permite que o Protégé gere a descrição da classe em linguagem natural (English Prose Tooltip Generator) (HORRIDGE, 2004, p. 28);

- Definir a inversa de cada propriedade, ou seja, toda propriedade, sempre que possível, tem uma propriedade inversa associada a ela;

- Utilizar axiomas de fechamento (closure axiom) em descrição de classe, por meio de limitação de propriedade (property restriction), sempre que aplicável. Esta técnica consiste em definir a restrição universal em conjunto com a restrição existencial e deve ser usada porque o motor de inferência RACER assume a premissa de Mundo Aberto (ver seção 3.5.4). Assim, a restrição universal deve ser definida sempre que for pertinente especificar que, além da existência de pelo menos um relacionamento entre os indivíduos da classe sendo descrita (domínio da propriedade) e os indivíduos da classe imagem da propriedade, todos os relacionamentos ocorrem com os indivíduos desta classe imagem (HORRIDGE, 2004, p. 70);

- Utilizar axioma de cobertura (covering axiom) em descrição de classes sempre que aplicável (HORRIDGE, 2004, p. 75). Esta técnica consiste em definir que todos os membros da superclasse são membros de uma de suas subclasses, ou seja, não existe nenhuma instância da superclasse que não seja também 
instância de uma de suas subclasses. Por exemplo, todos os membros da classe Agente são Indivíduos ou Grupo de Indivíduos, não existindo nenhum agente que não seja nem um individuo nem um grupo;

- Utilizar o motor de inferência RACER para fazer a verificação de consistência da ontologia durante toda a atividade de codificação, de forma a identificar rapidamente a inserção de definições inconsistentes;

- Evitar a especificação de domínios durante a definição de propriedades, visto que tal especificação funciona como um axioma e não como uma restrição durante a inferência sobre a ontologia, gerando inconsistências de difícil diagnóstico (HORRIDGE, 2004, p.35);

- Evitar o uso do construtor owl:hasValue na descrição de classes, já que este causa resultados inesperados (HORRIDGE, 2004, p.95), porque o raciocínio com instâncias não é completo no RACER.

A figura 5.15 mostra uma tela do Protégé com as principais classes da Ontologia Funcional de Reputação.

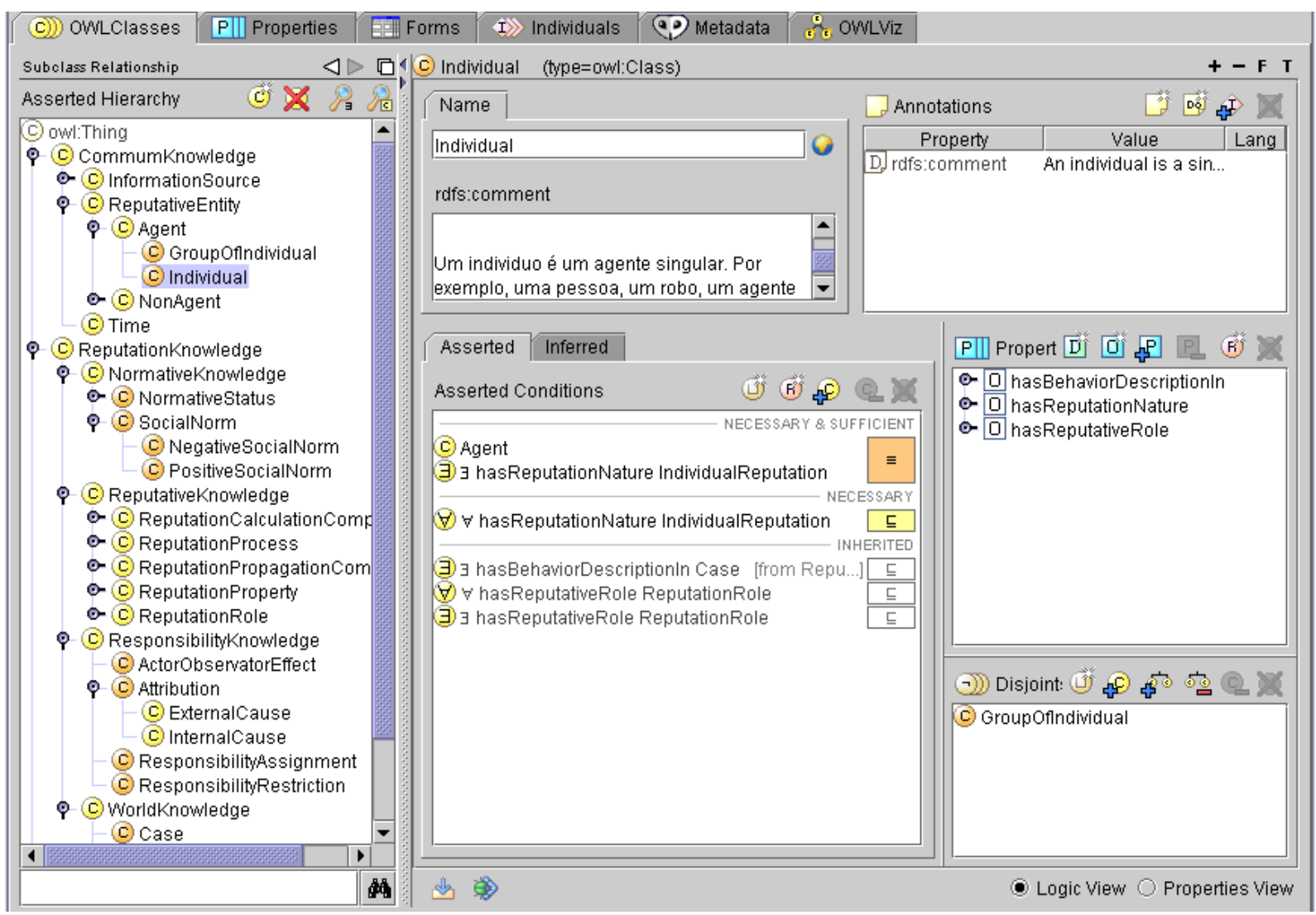

Figura 5.15: Tela do Protégé apresentando uma parte das classes da Ontologia Funcional de Reputação 
Na figura 5.15, a janela da esquerda, chamada de Hierarquia Definida (Assert Hierarchy) apresenta a hierarquia de classes, enquanto a janela central descreve as características da classe Individuo (Individual).

\subsection{Considerações Finais}

Esse capítulo apresentou as principais características da Ontologia Funcional de Reputação. A metodologia adotada para o desenvolvimento desta ontologia foi aquela proposta por Uschold e Gruninger (1996), envolvendo três fases principais: identificação de objetivo e de escopo, construção e avaliação.

O objetivo desta ontologia pode ser resumido da seguinte forma: oferecer uma perspectiva funcional para a análise da reputação como mecanismo de controle social, baseada tanto nas pesquisas realizadas no campo das Ciências Humanas (FERRIS et al., 2003; BROMLEY, 1993) como naquelas realizadas na área de IA, principalmente em SMA $^{31}$. O escopo desta ontologia foi definido por meio de questões de competência, especificadas a partir dos termos e noções de reputação utilizados pelos seis modelos e sistemas de reputação, apresentados na seção 2.2 .

Em linhas gerais, a construção da ontologia foi realizada em três etapas. A primeira etapa consistiu na captura dos conceitos relativos à noção de reputação, que formam o núcleo da ontologia. Na segunda etapa, este núcleo foi inserido em uma estrutura mais ampla, as categorias de conhecimento propostas pela Ontologia Funcional do Direito (VALENTE, 1995), sendo denominada categoria de Conhecimento Reputativo. Desta forma, a ontologia pode esboçar o sistema de reputação que ocorre na "mente" de um agente. Finalmente, as categorias, conceitos e relacionamentos foram codificados em uma linguagem formal baseada em lógica descritiva, a OWL DL.

Algumas considerações devem ser feitas sobre a escolha do método, linguagem e ferramentas envolvidas na construção da Ontologia Funcional de Reputação. A utilização da metodologia proposta por Uschold e Gruninger (1996) deveu-se a sua adequação à natureza deste trabalho e ao fato de descrever as atividades relacionadas à fase de avaliação de uma ontologia. A seleção da linguagem OWL DL envolveu diversos critérios de análise, tais como as funcionalidades oferecidas e a sua utilização pela comunidade acadêmica. Além de oferecer um plug-in para a linguagem OWL, o Protégé foi utilizado

\footnotetext{
${ }^{31}$ (ZACHARIA e MAES, 2000; CARTER et al., 2002; CONTE e PAOLUCCI, 2002; MAXIMILIEN e SINGH , 2002; MUI et al., 2002a,2003; SABATER, 2003).
} 
como ambiente de desenvolvimento por razões como seu amplo uso pela comunidade acadêmica e a existência de material de apoio de ótima qualidade. Finalmente, a escolha do RACER como motor de inferência deveu-se à facilidade de utilização junto com o Protégé e às características próprias do produto, tal como a rapidez de execução.

Tanto a metodologia como a linguagem e ferramentas adotadas foram de grande valia para o desenvolvimento deste trabalho. A metodologia mostrou-se ampla o suficiente para especificar de forma clara e consistente as principais atividades que devem ocorrer durante o desenvolvimento de uma ontologia, sem, contudo, perder-se nos detalhes de como essas atividades devem ser executadas, visto que este "como" depende tanto da linguagem e ferramentas utilizadas como do domínio do trabalho.

A linguagem OWL DL ofereceu a expressividade necessária para a implementação de todos os conceitos da ontologia. A desvantagem de usar tal linguagem, que consiste no manuseio de um código extenso e de difícil construção manual, foi mitigada pela utilização de um ambiente de desenvolvimento, o Protégé. Apesar de alguns problemas iniciais, que foram contornados com sucesso, o Protégé ofereceu todas as funcionalidades esperadas deste tipo de ambiente, tais como a geração do código OWL DL a partir de uma interface de fácil utilização e a representação gráfica da ontologia. Cabe ressaltar que o uso do tutorial desenvolvido por Horridge (2004), que apresenta a implementação de uma ontologia passo a passo, acelerou o aprendizado de OWL DL e do Protégé.

O RACER permitiu verificar a consistência da ontologia durante todo o desenvolvimento desta. Além disso, esta ferramenta foi essencial para a realização da fase de avaliação da ontologia, que é o tema do próximo capítulo desse texto. 


\section{Avaliação da Ontologia Funcional de Reputação}

O objetivo deste capítulo é apresentar o procedimento utilizado e os resultados obtidos na avaliação da Ontologia Funcional de Reputação, realizada a partir das questões de competências que delimitaram o seu escopo. Para tanto, as questões de competência foram formuladas em OWL DL e, em seguida, a ontologia foi classificada pelo motor de inferência RACER. Esta classificação produziu as respostas às questões de competência, através da subsunção das classes que representam essas questões em classes da ontologia.

Este capítulo está organizado da seguinte forma. Inicialmente, é apresentado na seção 6.1 o procedimento utilizado na avaliação da ontologia. Em seguida, as seções 6.2, 6.3, 6.4, 6.5, 6.6 e 6.7 apresentam, respectivamente, o procedimento e o resultado da avaliação dos seis modelos e sistemas de reputação que lhe delimitaram o escopo. A seção 6.8 sumariza as respostas obtidas para as questões de competência relativas a estes modelos e sistemas de reputação. Finalmente, a seção 6.9 apresenta algumas considerações sobre as avaliações realizadas.

\subsection{Procedimento de Avaliação da Ontologia}

O procedimento adotado para a avaliação da Ontologia Funcional de Reputação foi baseado na metodologia para construção e avaliação de ontologias proposta por Uschold e Gruninger (1996). A avaliação da ontologia foi realizada a partir das questões de competência que delimitaram seu escopo, descritas na seção 5.3.2. Tais questões envolvem os seis modelos e sistemas de reputação apresentados na seção 2.2: Modelo Cognitivo de Reputação, Modelo Tipologia de Reputação, Sistemas Histos e Sporas, Sistema de Reputação com Papéis, Sistema de Reputação e Endosso e Sistema Regret.

Como foi dito na seção 5.5, a língua inglesa foi utilizada na definição dos nomes e comentários de classes e propriedades da Ontologia Funcional de Reputação. Portanto, todas as classes utilizadas na avaliação da ontologia também foram definidas em inglês. $\mathrm{O}$ Anexo B contém a correspondência entre os nomes de classes e propriedades em português e em inglês. 
Este procedimento de avaliação consistiu nas seguintes atividades:

\section{Formulação das questões de competência em linguagem formal}

As questões de competência, até então descritas apenas em linguagem natural (ver seção 5.3.2), foram descritas em OWL DL. Os elementos usados na formulação destas questões, tais como as classes e propriedades, foram incorporadas à Ontologia Funcional de Reputação (USCHOLD e GRUNINGER, 1996, p.32);

Uma nova classe, chamada Ontology Evaluation Structure (Estrutura de Avaliação da Ontologia), foi criada no ambiente Protégé a fim de agrupar as questões de competência descritas em OWL DL.

A partir desta classe foram definidas seis subclasses para representar as questões de competência relacionadas aos seis modelos e sistemas de reputação: Cognitive Model Of Reputation (Modelo Cognitivo de Reputação), Typology Of Reputation (Modelo Tipologia de Reputação), Histos Sporas System (Sistemas Histos e Sporas), Reputation Based On Role System (Sistema de Reputação baseado em Papéis), Reputation and Endorsement System (Sistema de Reputação e Endosso), ReGret System (Sistema Regret). Os principais conceitos definidos em cada modelo e sistema de reputação foram então representados como subclasses dessas classes.

\section{Produção das respostas às questões de competência por meio de processo} de inferência

A execução desta atividade envolveu a ontologia, os elementos usados na formulação das questões de competência e o motor de inferência RACER (HAARSLEV e MOLLER, 2003) versão 1.7.23. As respostas às questões foram encontradas por meio da subsunção das classes que as expressam em classes da ontologia. Assim, as classes que representam tais questões foram associadas, via inferência, a superclasses da ontologia, que representam a resposta à questão.

\section{Análise do resultado do processo de inferência}

A análise do resultado consistiu em avaliar e discutir a consistência e expressividade oferecida pela Ontologia Funcional de Reputação, tanto para a descrição das questões de competência em seus termos, como na obtenção das respostas encontradas. 
A figura 6.1 mostra uma tela do ambiente Protégé (GENNARI et al., 2003) contendo a classe Ontology Evaluation Structure e suas subclasses: Cognitive Model Of Reputation, Typology Of Reputation, Histos Sporas System, Reputation Based On Role System, Reputation and Endorsement System, ReGret System. A título de exemplo, esta tela apresenta também as subclasses de Typology Of Reputation, ressaltando a descrição da subclasse Prior Derived Reputation (Reputação Derivada Anterior). À esquerda da figura, a janela Assert Hierarchy (hierarquia definida) apresenta a hierarquia de classes, enquanto a janela à direita mostra a descrição da classe Prior Derived Reputation nos termos da Ontologia Funcional de Reputação.

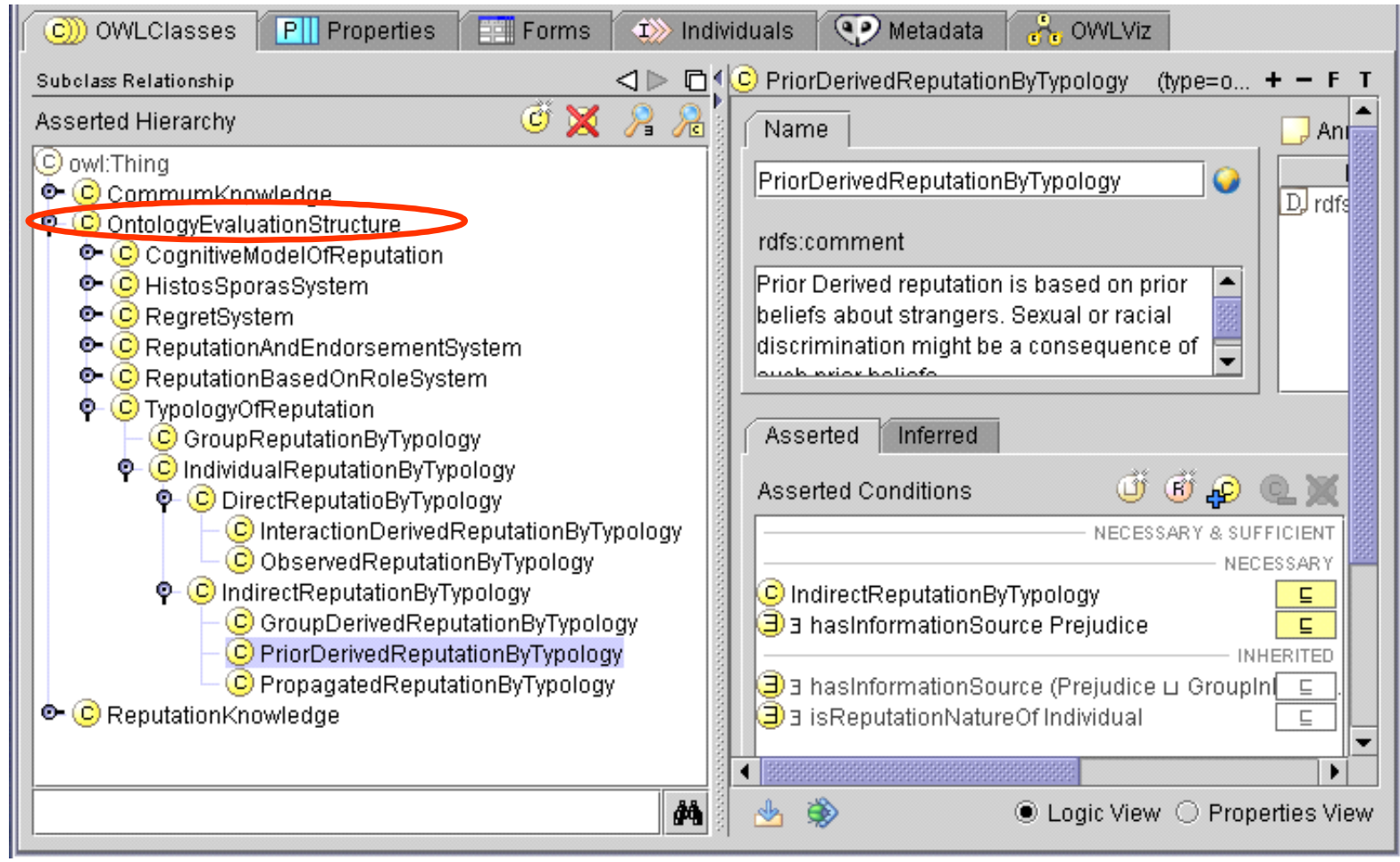

Figura 6.1: Representação das classes usadas na avaliação da Ontologia Funcional de Reputação

A seguir, são apresentados tanto os procedimentos de avaliação da Ontologia Funcional de Reputação como os seus resultados. O seguinte critério foi adotado para a grafia de nomes de conceitos, classes e propriedades envolvidas nesta avaliação:

- os nomes dos conceitos dos modelos e sistemas de reputação estão grafados na fonte Comic Sans MS;

- os nomes das classes destes modelos e sistemas estão grafados em Arial sublinhado;

- os nomes das classes e propriedades da Ontologia Funcional de Reputação estão grafados em Arial. 


\subsection{Avaliação Utilizando o Modelo Cognitivo de Reputação}

Reputação e Imagem são os principais conceitos do Modelo Cognitivo de Reputação proposto por Conte e Paolucci (2002) (ver seção 2.2.2). Estes conceitos envolvem os conjuntos de agentes que participam tanto da formação da imagem como da transmissão da reputação, quais sejam, os agentes alvos, os agentes avaliadores, os agentes transmissores e os agentes beneficiários. Este modelo apresenta os diversos aspectos relacionados à transmissão da reputação na esfera social: por que transmitir, sobre quem transmitir, para quem transmitir e como transmitir.

\subsubsection{Questões de Competência}

A classe CognitiveModelOfReputation foi definida no ambiente Protégé para representar as questões de competência relacionadas ao Modelo Cognitivo de Reputação. Os principais conceitos deste modelo foram definidos como suas subclasses. O nome de tais subclasses indica, por meio de um sufixo, o nome do modelo ao qual pertence: ByCognitiveMod. O objetivo deste procedimento é facilitar o reconhecimento do conceito e evitar nomes repetidos.

A figura 6.2 mostra o diagrama das classes que representam os conceitos do Modelo Cognitivo de Reputação.

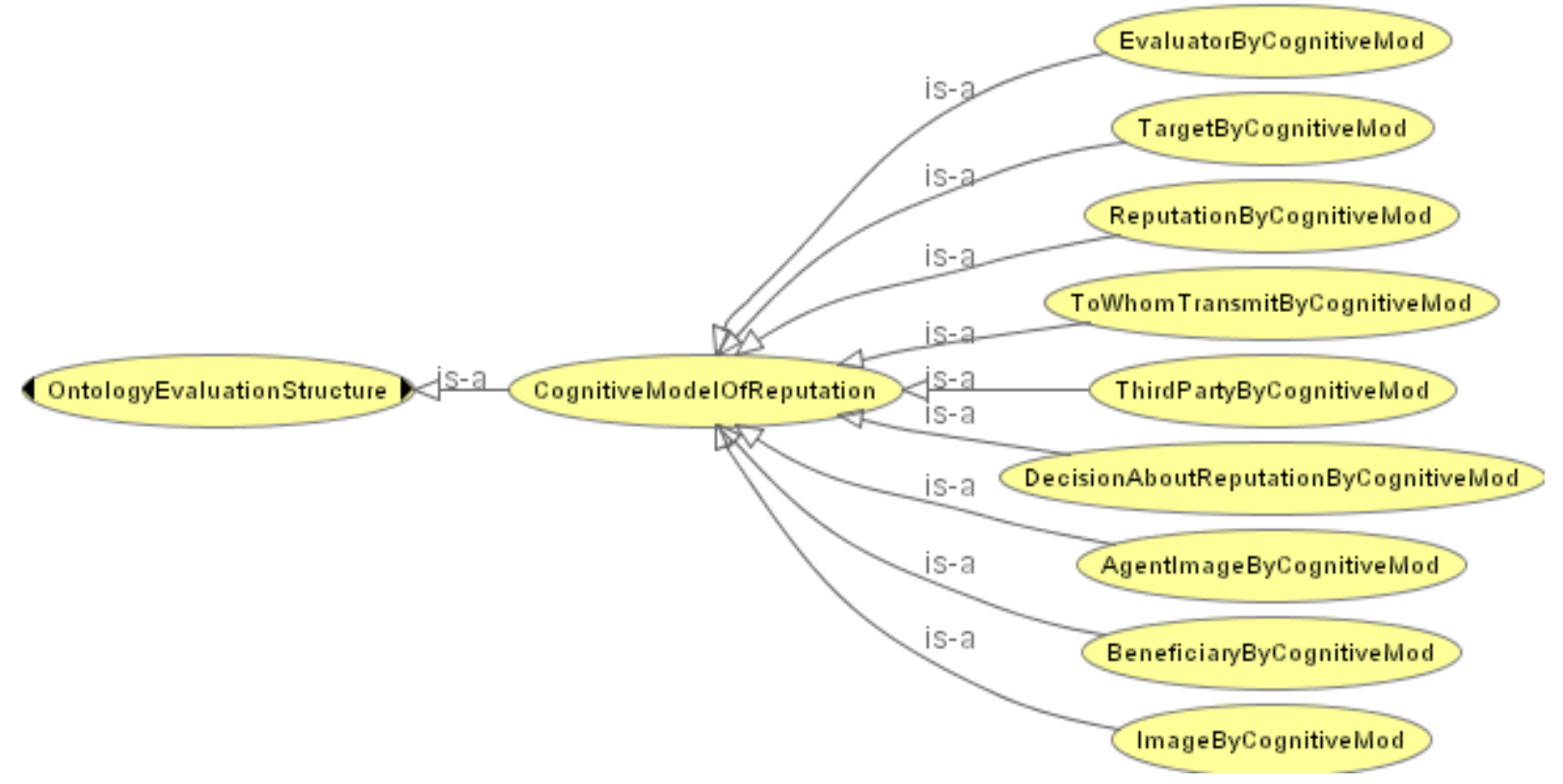

Figura 6.2: Diagrama das classes que representam os conceitos do Modelo Cognitivo de Reputação 
A tabela 6.1 mostra (i) os nomes das classes OWL DL criadas para representar os conceitos deste modelo, (ii) o nome e a definição dos conceitos a partir dos quais foram definidas as questões de competência, (iii) as descrições em linguagem natural dessas questões usando os elementos da ontologia (classes e propriedades ${ }^{32}$ ).

Tabela 6.1: Questões de competência e respectivas classes OWL DL para conceitos do Modelo Cognitivo de Reputação

\begin{tabular}{|c|c|c|}
\hline $\begin{array}{c}\text { Classe em } \\
\text { OWL DL }\end{array}$ & $\begin{array}{c}\text { Conceitos Modelo } \\
\text { Cognitivo de Reputação }\end{array}$ & $\begin{array}{c}\text { Descrição das questões em } \\
\text { termos ontológicos }\end{array}$ \\
\hline$\underline{\text { ByCognitiveMod }}$ & $\begin{array}{l}\quad \text { Imagem do agente } \\
\text { A imagem aplica-se a um individuo } \\
\text { ou agente. }\end{array}$ & $\begin{array}{l}\text { As instâncias desta classe têm pelo menos } \\
\text { uma associação através da propriedade } \\
\text { éNaturezaReputaçãoDe com instâncias } \\
\text { da classe Individuo. }\end{array}$ \\
\hline$\underline{\text { Image }}$ & \begin{tabular}{l}
\multicolumn{3}{c}{ Imagem } \\
É uma crença que representa a \\
avaliação que um agente faz de \\
outro agente a partir das \\
informações adquiridas pela \\
experiência.
\end{tabular} & $\begin{array}{l}\text { As instâncias desta classe têm pelo menos } \\
\text { uma associação através da propriedade } \\
\text { temFontelnformação com instâncias } \\
\text { das classes Experiência Direta ou } \\
\text { Observação. }\end{array}$ \\
\hline By $\frac{\text { Reputation }}{\text { CognitiveMod }}$ & $\begin{array}{l}\text { Reputação } \\
\text { Resulta da transmissão de uma } \\
\text { imagem. Pode ser herdada do grupo } \\
\text { social ao qual o agente pertence, ou } \\
\text { refletir relacionamentos de } \\
\text { similaridade (preconceito). }\end{array}$ & $\begin{array}{l}\text { As instâncias desta classe têm pelo menos } \\
\text { uma associação através da propriedade } \\
\text { temFonteInformação com instâncias } \\
\text { das classes Informação De Terceiro, } \\
\text { Herança de Grupo ou Preconceito. }\end{array}$ \\
\hline$\underset{\text { ByCognitiveMod }}{\underline{\text { Target }}}$ & $\begin{array}{l}\text { Conjunto de agentes alvos } \\
\text { Agentes aos quais se aplica a } \\
\text { imagem ou reputação. }\end{array}$ & $\begin{array}{l}\text { As instâncias desta classe têm pelo menos } \\
\text { uma associação através da propriedade } \\
\text { temReputação com instâncias da classe } \\
\text { TipoReputação. }\end{array}$ \\
\hline $\begin{array}{c}\text { Evaluator } \\
\text { ByCognitiveMod }\end{array}$ & $\begin{array}{l}\text { Conjunto de agentes avaliadores } \\
\text { Agentes capazes de formar uma } \\
\text { crença avaliadora sobre os outros, a } \\
\text { partir das interações ou percepções } \\
\text { sociais. }\end{array}$ & $\begin{array}{l}\text { As instâncias desta classe têm pelo menos } \\
\text { uma associação através da propriedade } \\
\text { temProcessoReputativo com instâncias } \\
\text { da classe Processo Avaliação } \\
\text { Reputação. }\end{array}$ \\
\hline $\begin{array}{c}\text { ThirdParty } \\
\text { ByCognitiveMod } \\
\underline{\text { Con }}\end{array}$ & $\begin{array}{l}\text { Conjunto de agentes } \\
\quad \text { transmissores } \\
\text { Agentes capazes de transmitir uma } \\
\text { reputação. }\end{array}$ & $\begin{array}{l}\text { As instâncias desta classe têm pelo menos } \\
\text { uma associação através da propriedade } \\
\text { temProcessoReputativo com instâncias } \\
\text { da classe Processo Transmissão } \\
\text { Reputação. }\end{array}$ \\
\hline $\begin{array}{c}\text { Beneficiary } \\
\text { ByCognitiveMod }\end{array}$ & $\begin{array}{l}\text { Conjunto de agentes beneficiários } \\
\text { Agentes que compartilham o } \\
\text { objetivo (goal) a respeito do qual os } \\
\text { agentes alvo são avaliados e para os } \\
\text { quais a avaliação dos alvos traz } \\
\text { algum benefício. }\end{array}$ & $\begin{array}{l}\text { Não foi possível descrever esta classe } \\
\text { em termos ontológicos (ver seção 6.2.3) }\end{array}$ \\
\hline
\end{tabular}

\footnotetext{
${ }^{32}$ O Anexo B contém a correspondência entre os nomes de classes e propriedades em português e em inglês.
} 


\begin{tabular}{|c|c|c|}
\hline $\begin{array}{l}\text { Classe em } \\
\text { OWL DL }\end{array}$ & $\begin{array}{c}\text { Conceitos Modelo } \\
\text { Cognitivo de Reputação }\end{array}$ & $\begin{array}{c}\text { Descrição das questões em } \\
\text { termos ontológicos }\end{array}$ \\
\hline $\begin{array}{c}\text { ToWhom } \\
\text { Transmit } \\
\text { ByCognitiveMod }\end{array}$ & \begin{tabular}{l} 
Para quem transmitir uma \\
\multicolumn{1}{c}{ reputação } \\
Aspecto da transmissão da \\
reputação, relacionado à escolha do \\
receptor na esfera social.
\end{tabular} & $\begin{array}{l}\text { As instâncias desta classe têm pelo menos } \\
\text { uma associação através da propriedade } \\
\text { temProcessoReputativo com instâncias } \\
\text { da classe Processo Recepção } \\
\text { Reputação. }\end{array}$ \\
\hline $\begin{array}{l}\text { DecisionAbout } \\
\text { Reputation } \\
\text { ByCognitiveMod }\end{array}$ & $\begin{array}{l}\text { Decisão sobre a Transmissão de } \\
\quad \text { uma Reputação } \\
\text { Aspectos relacionados às questões } \\
\text { por que transmitir, sobre quem } \\
\text { transmitir e como transmitir. }\end{array}$ & $\begin{array}{l}\text { As instâncias desta classe têm pelo menos } \\
\text { uma associação através da propriedade } \\
\text { éComponente com instâncias da classe } \\
\text { Processo Transmissão Reputação. }\end{array}$ \\
\hline
\end{tabular}

\subsubsection{Inferência das Respostas}

Após a definição da classe CognitiveReputationModel e de suas subclasses no ambiente Protégé, o motor de inferência RACER foi utilizado para classificar todas as classes da ontologia. As respostas às questões de competência foram então encontradas por meio da subsunção das classes que representam os conceitos do Modelo Cognitivo de Reputação em classes da Ontologia Funcional de Reputação, associando as primeiras como subclasses das últimas.

A figura 6.3 mostra uma tela do ambiente Protégé contendo, (i) na janela ao centro, o botão que permite acessar o motor de inferência RACER para executar a subsunção da ontologia (Classify Taxonomy), (ii) na janela à esquerda, a hierarquia de classes definida manualmente e (iii) na janela à direita, a hierarquia inferida para a classe ReputationByCognitiveMod. Esta figura ressalta a classe ReputationByCognitiveModel nas duas hierarquias, à esquerda como subclasse de CognitiveReputationModel e, à direita, como subclasse de CognitiveReputationModel e de SecondaryReputation. 


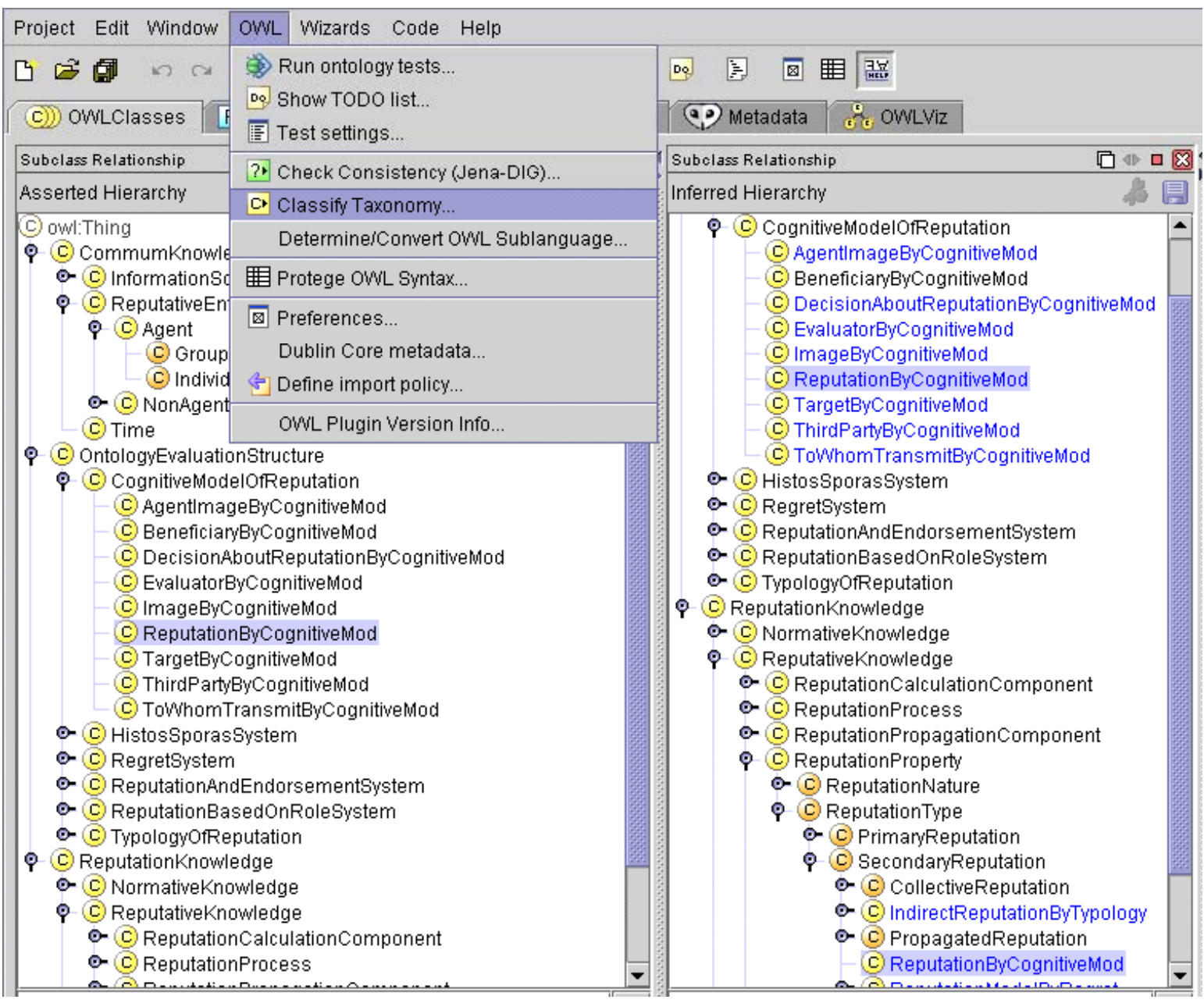

Figura 6.3: Representação do procedimento de subsunção da ontologia e de seu resultado

A figura 6.4 apresenta o diagrama da hierarquia inferida pelo RACER, mostrando, para as classes que representam os conceitos do Modelo Cognitivo de Reputação (assinaladas pela linha pontilhada), quais foram as superclasses a elas associadas pelo processo de subsunção da ontologia. Tal diagrama é gerado automaticamente pelo Protégé após a classificação da ontologia. 


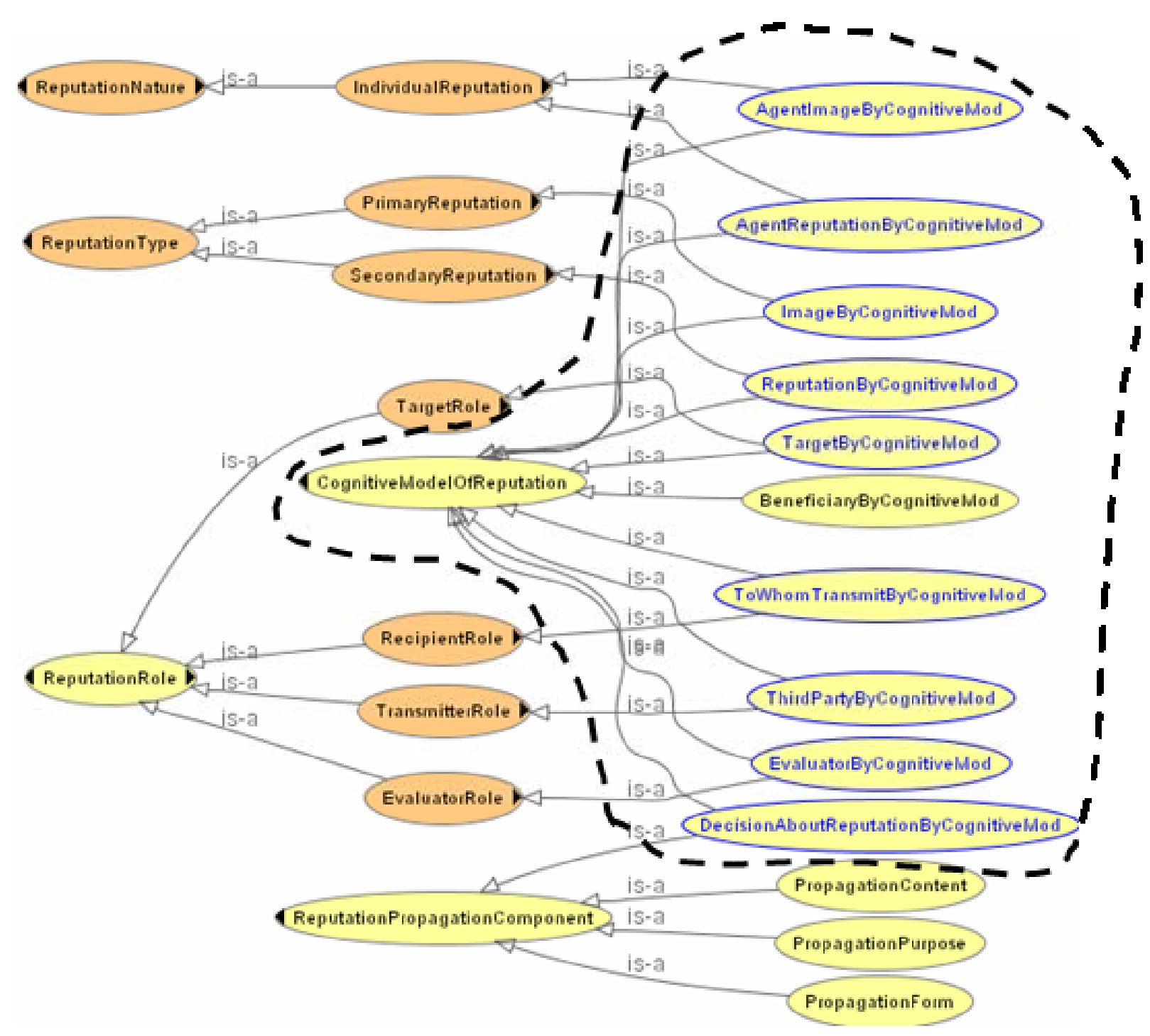

Figura 6.4: Diagrama da hierarquia inferida para as classes do Modelo Cognitivo de Reputação, realçadas pela linha pontilhada, mostrando as superclasses a elas associadas pelo processo de subsunção

\subsubsection{Discussão e Avaliação}

A Ontologia Funcional de Reputação forneceu a expressividade necessária para a definição consistente da maioria dos conceitos do Modelo Cognitivo de Reputação. A exceção consistiu no conceito Conjunto de Agentes Beneficiários, discutido a seguir.

Em relação ao conceito Imagem do Agente, foi possível inferir que a classe AgentImageByCognitiveMod, que o representa, é subclasse de IndividualReputation. Foi possível inferir também que as classes ImageByCognitiveMod e ReputationByCognitiveMod, são subclasses de PrimaryReputation (Reputação Primária) e SecondaryReputation (Reputação Secundária), respectivamente. 
As classes TargetByCognitiveMod, EvaluatorByCognitiveMod e ThirdPartyByCognitiveMod foram definidas de forma consistente e com a expressividade necessária a partir dos elementos da ontologia. Entretanto, não foi possível definir a classe BeneficiaryByCognitiveMod, já que o conceito por ela representado está relacionado à noção de objetivo do agente e de compartilhamento do mesmo. Tais noções envolvem a definição de conceitos mais amplos, como cognição e estados mentais (crença, desejo, intenção) (RAO e GEORGEFF, 1995), que não estão representados na Ontologia Funcional de Reputação.

O conceito Para quem transmitir uma reputação, representado pela classe ToWhomTransmitByCognitiveMod, foi expresso por meio da classe RecipientRole (Papel Receptor), visto que a escolha do agente para o qual transmitir uma reputação é similar à escolha do agente que desempenhará o papel de receptor da informação.

Finalmente, a classe DecisionAboutReputationByCognitiveMod foi subsumida pela classe ReputationPropagationComponent (Componente Propagação Reputação), que representa os elementos envolvidos na propagação de uma reputação.

\subsection{Avaliação Utilizando o Modelo Tipologia de Reputação}

O Modelo Tipologia de Reputação proposto por Mui et al.(2002a, 2003) (ver seção 2.2.3) representa a reputação por meio de duas dimensões de análise: segundo a natureza da entidade alvo e segundo a fonte de informação utilizada.

\subsubsection{Questões de Competência}

A classe TypologyOfReputation e suas subclasses representam as questões de competência relacionadas ao Modelo Tipologia de Reputação. O nome de tais subclasses indica, por meio de um sufixo, o nome do modelo ao qual pertence: ByTypology.

A figura 6.5 mostra o diagrama das classes que representam estes conceitos. 


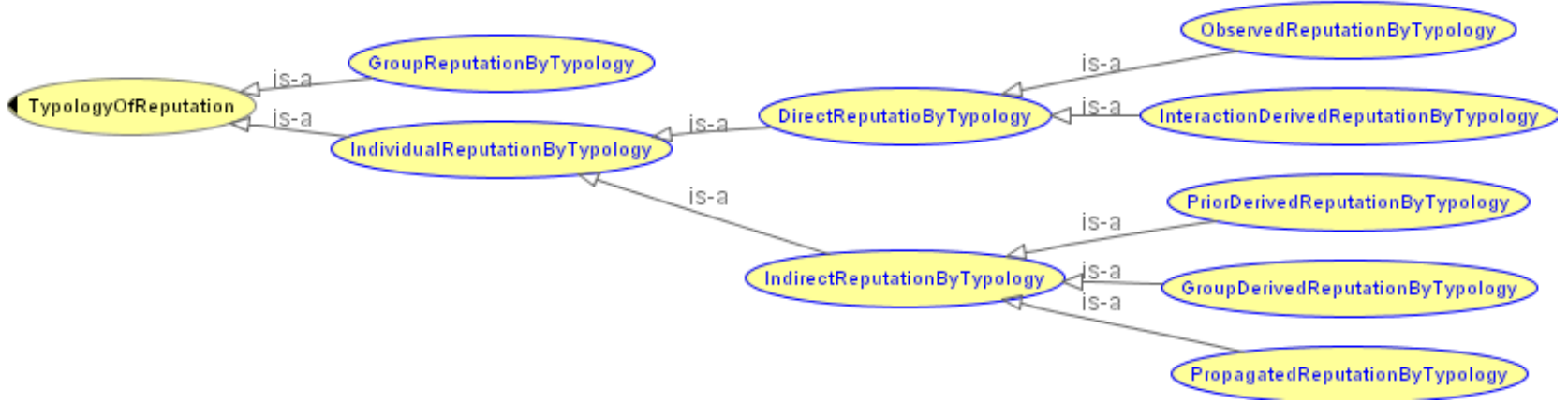

Figura 6.5: Diagrama das classes que representam os conceitos do Modelo Tipologia de Reputação

A tabela 6.2 mostra (i) os nomes das classes OWL DL criadas para representar os conceitos do Modelo Tipologia da Reputação, (ii) o nome e a definição dos conceitos a partir dos quais foram definidas as questões de competência, (iii) as descrições dessas questões usando os elementos da ontologia.

Tabela 6.2: Questões de competência e respectivas classes OWL DL para conceitos do Modelo Tipologia de Reputação

\begin{tabular}{|c|c|c|}
\hline $\begin{array}{l}\text { Classe em } \\
\text { OWL DL }\end{array}$ & $\begin{array}{l}\text { Conceitos do Modelo } \\
\text { Tipologia de Reputação }\end{array}$ & $\begin{array}{l}\text { Descrição das questões em } \\
\text { termos ontológicos }\end{array}$ \\
\hline $\begin{array}{l}\frac{\text { Individual }}{\text { Reputation }} \\
\text { ByTypology }\end{array}$ & $\begin{array}{l}\text { Reputação Individual } \\
\text { É usada para descrever um } \\
\text { individuo. }\end{array}$ & $\begin{array}{l}\text { As instâncias desta classe têm pelo menos } \\
\text { uma associação através da propriedade } \\
\text { éNaturezaReputaçãoDe com instâncias } \\
\text { da classe Individuo. }\end{array}$ \\
\hline $\begin{array}{l}\frac{\text { Group }}{\text { Reputation }} \\
\text { ByTypology }\end{array}$ & $\begin{array}{l}\quad \text { Reputação de Grupo } \\
\text { É usada para descrever grupos de } \\
\text { indivíduos. }\end{array}$ & $\begin{array}{l}\text { As instâncias desta classe têm pelo menos } \\
\text { uma associação através da propriedade } \\
\text { éNaturezaReputaçãoDe com instâncias } \\
\text { da classe Grupo De Indivíduos. }\end{array}$ \\
\hline$\frac{\text { DirectReputation }}{\text { ByTypology }}$ & $\begin{array}{l}\text { Reputação Direta } \\
\text { É a reputação individual que deriva } \\
\text { dos encontros diretos entre os } \\
\text { indivíduos ou da observação dos } \\
\text { mesmos. }\end{array}$ & $\begin{array}{l}\text { As instâncias desta classe têm pelo menos } \\
\text { uma associação através da propriedade } \\
\text { temFontelnformação com instâncias das } \\
\text { classes Experiência Direta ou Observação }\end{array}$ \\
\hline$\frac{\frac{\text { Interaction }}{\text { Derived }}}{\text { Reputation }}$ & $\begin{array}{l}\quad \text { Reputação Derivada da } \\
\quad \text { Interação } \\
\text { É a reputação individual baseada } \\
\text { nos encontros diretos ocorridos } \\
\text { entre o agente avaliador e o agente } \\
\text { alvo da reputação. }\end{array}$ & $\begin{array}{l}\text { As instâncias desta classe têm pelo menos } \\
\text { uma associação através da propriedade } \\
\text { temFontelnformação com instâncias da } \\
\text { classe Experiência Direta }\end{array}$ \\
\hline$\frac{\text { Observed }}{\frac{\text { Reputation }}{\text { ByTypology }}}$ & $\begin{array}{l}\text { Reputação Observada } \\
\text { Representa a reputação } \\
\text { individual que resulta das } \\
\text { observações feitas dos encontros } \\
\text { entre agentes. }\end{array}$ & $\begin{array}{l}\text { As instâncias desta classe têm pelo menos } \\
\text { uma associação através da propriedade } \\
\text { temFontelnformação com instâncias da } \\
\text { classe Observação }\end{array}$ \\
\hline
\end{tabular}




\begin{tabular}{|c|c|c|}
\hline $\begin{array}{l}\text { Classe em } \\
\text { OWL DL }\end{array}$ & $\begin{array}{l}\text { Conceitos do Modelo } \\
\text { Tipologia de Reputação }\end{array}$ & $\begin{array}{l}\text { Descrição das questões em } \\
\text { termos ontológicos }\end{array}$ \\
\hline $\begin{array}{c}\frac{\text { Indirect }}{\text { Reputation }} \\
\text { ByTypology }\end{array}$ & $\begin{array}{l}\text { Reputação Indireta } \\
\text { Representa a reputação individual } \\
\text { baseada em evidencias de segunda } \\
\text { mão, incluindo informação } \\
\text { recebida, preconceitos e reputação } \\
\text { derivada de grupo. }\end{array}$ & $\begin{array}{l}\text { As instâncias desta classe têm pelo menos } \\
\text { uma associação através da propriedade } \\
\text { temFontelnformação com instâncias das } \\
\text { classes InformaçãoDeTerceiro, } \\
\text { Preconceito ou HerançaDeGrupo. }\end{array}$ \\
\hline$\frac{\frac{\text { GroupDerived }}{\text { Reputation }}}{\text { ByTypology }}$ & $\begin{array}{l}\text { Reputação Derivada Grupo } \\
\text { Representa a reputação individual } \\
\text { que o agente possui devido a sua } \\
\text { participação em determinado grupo } \\
\text { social. }\end{array}$ & $\begin{array}{l}\text { As instâncias desta classe têm pelo menos } \\
\text { uma associação através da propriedade } \\
\text { temFontelnformação com instâncias da } \\
\text { classe HerançaDeGrupo. }\end{array}$ \\
\hline$\frac{\frac{\text { PriorDerived }}{\text { Reputation }}}{\text { ByTypology }}$ & $\begin{array}{l}\text { Reputação Derivada Anterior } \\
\text { Representa a reputação individual } \\
\text { baseada em preconceitos sociais. }\end{array}$ & $\begin{array}{l}\text { As instâncias desta classe têm pelo menos } \\
\text { uma associação através da propriedade } \\
\text { temFontelnformação com instâncias da } \\
\text { classe Preconceito. }\end{array}$ \\
\hline$\frac{\frac{\text { Propagated }}{\text { Reputation }}}{\text { ByTypology }}$ & $\begin{array}{l}\text { Reputação Propagada } \\
\text { Representa a reputação individual } \\
\text { baseada nas informações recebidas } \\
\text { de outros agentes. }\end{array}$ & $\begin{array}{l}\text { As instâncias desta classe têm pelo menos } \\
\text { uma associação através da propriedade } \\
\text { temFontelnformação com instâncias da } \\
\text { classe InformaçãoDeTerceiro. }\end{array}$ \\
\hline
\end{tabular}

\subsubsection{Inferência das Respostas}

A figura 6.6 mostra o diagrama da hierarquia de classes inferida pelo RACER, mostrando, para as classes que representam os conceitos do Modelo Tipologia de Reputação (entre as duas linhas pontilhadas), quais foram as superclasses a elas associadas pelo processo de subsunção da ontologia.

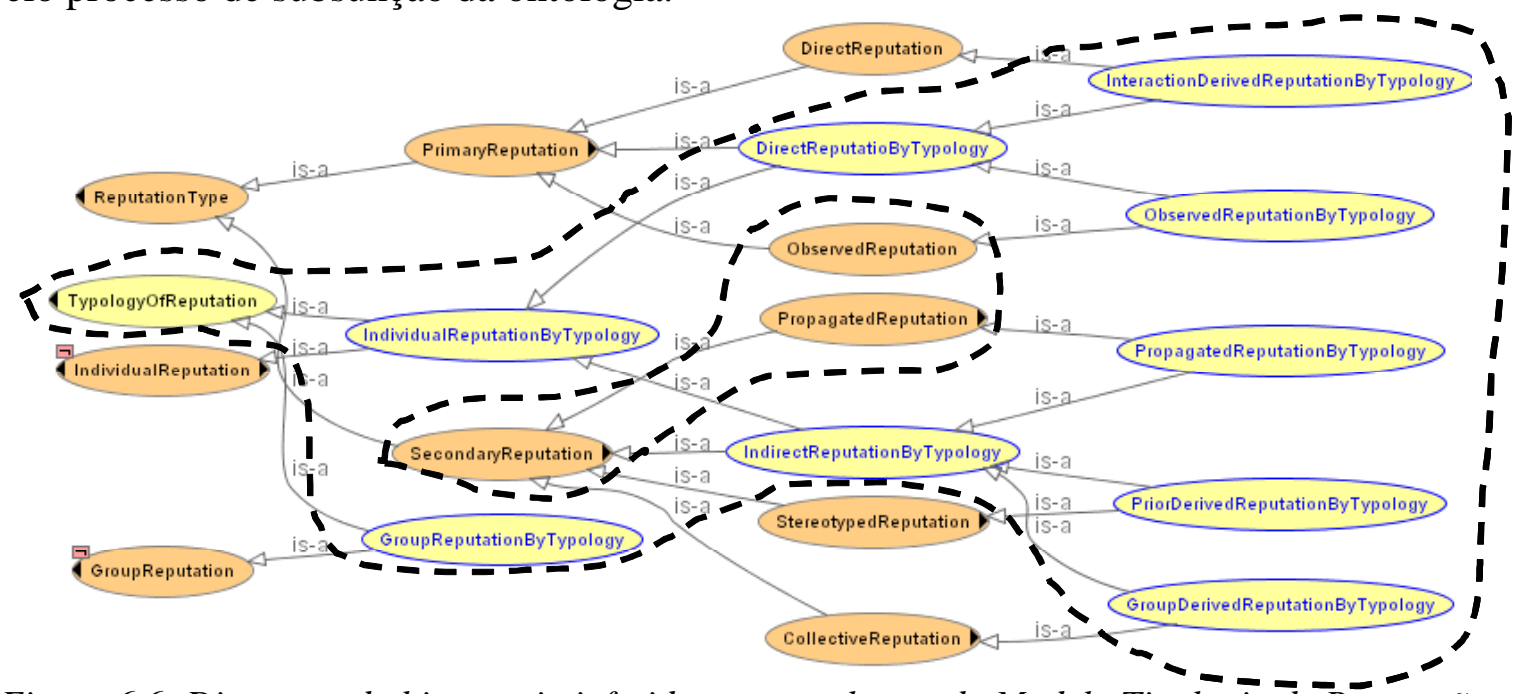

Figura 6.6: Diagrama da hierarquia inferida para as classes do Modelo Tipologia $\bar{d}$ - Rēputação, representadas entre as linhas pontilhadas, mostrando as superclasses a elas associadas pelo processo de subsunção 


\subsubsection{Discussão e Avaliação}

A ontologia ofereceu a expressividade necessária, e de forma consistente, para a representação de todos os conceitos do Modelo Tipologia de Reputação.

Os conceitos Reputação Individual e Reputação de Grupo, representados respectivamente pelas classes IndividualReputationByTypology e GroupReputationByTypology foram subsumidos pelas classes IndividualReputation e GroupReputation.

Os conceitos Reputação Direta, Reputação Indireta e seus sub-conceitos, representados pelas classes DirectReputationByTypology, IndirectReputationByTypology e suas subclasses, foram subsumidos pelas classes da ontologia PrimaryReputation (Reputação Primária) e SecondaryReputation (Reputação Secundária) e suas subclasses, respectivamente.

Cabe ressaltar que foi possível, através da Ontologia Funcional de Reputação, reproduzir, de forma consistente, a hierarquia de classes existente no Modelo Tipologia de Reputação. Por exemplo, a relação de superclasse-subclasse existente entre IndirectReputationByTypology e GroupReputationByTypology, foi reproduzida pela relação de superclasse-subclasse entre SecondaryReputation e CollectiveReputation, as classes da ontologia que subsumem tais classes da Tipologia de Reputação.

\subsection{Avaliação Utilizando os Modelos Histos e Sporas}

Histos e Sporas (ver seção 2.2.4) são sistemas para a avaliação da reputação dos indivíduos que participam como usuários de ambientes de comércio eletrônico. A reputação de um usuário resulta das avaliações fornecidas pelos demais usuários após cada transação realizada nestes ambientes. Nos dois sistemas as avaliações são coletadas e mantidas por um componente central do sistema,que calcula o valor da reputação dos usuários a partir da agregação das diversas avaliações feitas.

\subsubsection{Questões de Competência}

A classe HistosSporasSystem e suas subclasses foram definidas para representar as questões de competência relacionadas aos conceitos dos Sistemas Histos e Sporas. O nome das subclasses indica, por meio de um sufixo, o nome do sistema ao qual pertence: ByHistosSporas.

A figura 6.7 mostra o diagrama das classes que representam estes conceitos. 


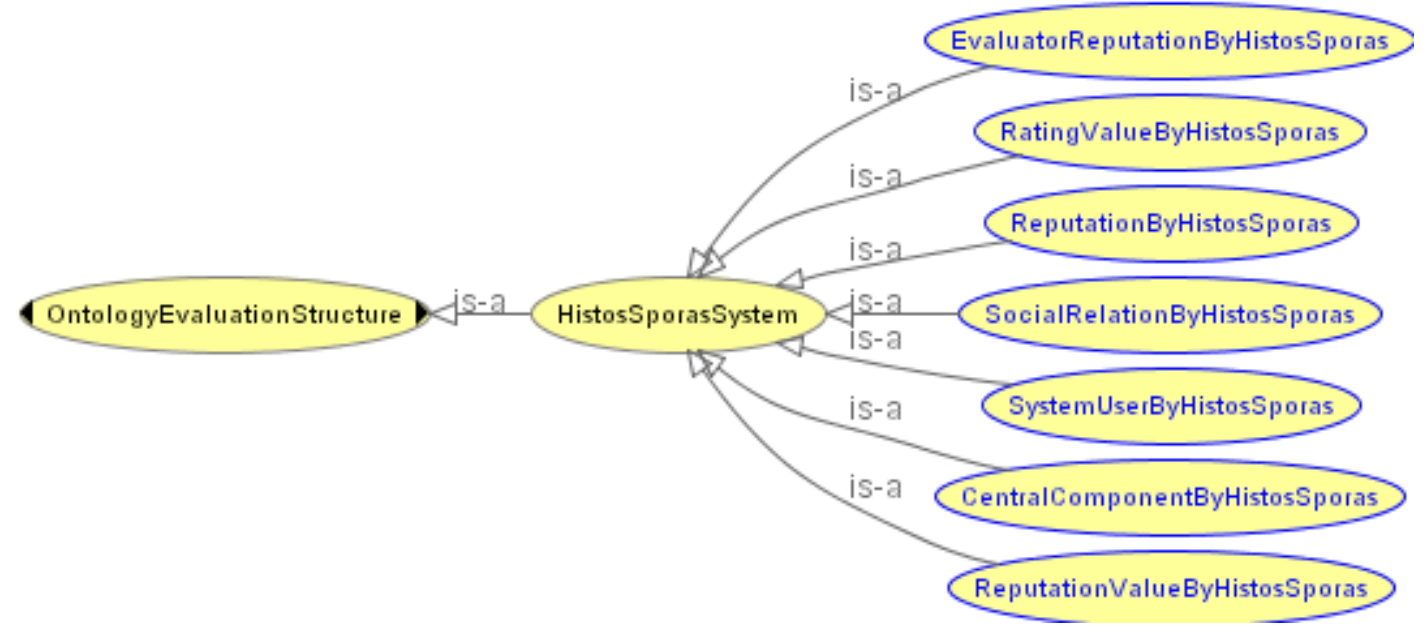

Figura 6.7: Diagrama das classes que representam os conceitos dos Sistemas Histos e Sporas

A tabela 6.3 mostra (i) os nomes das classes OWL DL definidas para representar os conceitos de Histos e Sporas, (ii) o nome e a descrição, em linguagem natural, de tais conceitos, a partir dos quais foram definidas as questões de competência, e (iii) as descrições dessas questões usando os elementos da ontologia.

Tabela 6.3: Questões de competência e respectivas classes OWL DL para conceitos dos Sistemas Histos e Sporas

\begin{tabular}{|c|c|c|}
\hline $\begin{array}{l}\text { Classe em } \\
\text { OWL DL }\end{array}$ & $\begin{array}{l}\text { Conceitos dos Sistemas } \\
\text { Histos e Sporas }\end{array}$ & $\begin{array}{c}\text { Descrição das questões em termos } \\
\text { ontológicos }\end{array}$ \\
\hline$\frac{\text { Reputation }}{\text { ByHistosSporas }}$ & $\begin{array}{l}\text { Reputação } \\
\text { Os valores da reputação são } \\
\text { associados aos indivíduos. }\end{array}$ & $\begin{array}{l}\text { As instâncias desta classe têm pelo menos } \\
\text { uma associação através da propriedade } \\
\text { éNaturezaReputaçãoDe com instâncias da } \\
\text { classe Individuo. }\end{array}$ \\
\hline $\begin{array}{c}\text { SystemUser } \\
\text { ByHistosSporas }\end{array}$ & $\begin{array}{l}\text { Usuário do Sistema } \\
\text { Os indivíduos que utilizam o } \\
\text { ambiente de comércio } \\
\text { eletrônico avaliam os seus pares } \\
\text { e recebem a reputação } \\
\text { calculada pelo componente } \\
\text { central do sistema. }\end{array}$ & $\begin{array}{l}\text { As instâncias desta classe têm pelo menos } \\
\text { uma associação através da propriedade } \\
\text { temReputação com instâncias da classe Tipo } \\
\text { De Reputação. } \\
\text { As instâncias desta classe têm pelo menos } \\
\text { uma associação através da propriedade } \\
\text { temProcessoReputativo com instâncias das } \\
\text { classes Processo Avaliação Reputação e } \\
\text { Processo Recepcão Reputação. }\end{array}$ \\
\hline $\begin{array}{c}\text { Central } \\
\text { Component } \\
\text { ByHistosSporas }\end{array}$ & $\begin{array}{l}\text { Componente Central do } \\
\text { sistema } \\
\text { Calcula, a partir das avaliações, } \\
\text { o valor da reputação dos } \\
\text { usuários, e o transmite este } \\
\text { valor. }\end{array}$ & $\begin{array}{l}\text { As instâncias desta classe têm pelo menos } \\
\text { uma associação através da propriedade } \\
\text { temProcessoReputativo com instâncias das } \\
\text { classes Processo Manutenção Reputação, } \\
\text { Processo Transmissão Reputação }\end{array}$ \\
\hline$\frac{\text { RatingValue }}{\text { ByHistosSporas }}$ & $\begin{array}{l}\text { Valor da Avaliação } \\
\text { É o valor da avaliação atribuída } \\
\text { a um usuário por um outro } \\
\text { usuário. }\end{array}$ & $\begin{array}{l}\text { As instâncias desta classe têm pelo menos } \\
\text { uma associação através da propriedade } \\
\text { éSaída com instâncias da classe Processo } \\
\text { Avaliação Reputação. }\end{array}$ \\
\hline
\end{tabular}




\begin{tabular}{|c|c|c|}
\hline $\begin{array}{l}\text { Classe em } \\
\text { OWL DL }\end{array}$ & $\begin{array}{l}\text { Conceitos dos Sistemas } \\
\text { Histos e Sporas }\end{array}$ & $\begin{array}{c}\text { Descrição das questões em termos } \\
\text { ontológicos }\end{array}$ \\
\hline$\frac{\text { ReputationValue }}{\text { ByHistosSporas }}$ & $\begin{array}{l}\quad \text { Valor da Reputação } \\
\text { É o valor que representa a } \\
\text { reputação dos usuários. }\end{array}$ & $\begin{array}{l}\text { As instâncias desta classe têm pelo menos } \\
\text { uma associação através da propriedade } \\
\text { éSaída com instâncias da classe Processo } \\
\text { Manutenção Reputação. }\end{array}$ \\
\hline$\frac{\text { SocialRelation }}{\text { ByHistosSporas }}$ & $\begin{array}{l}\text { Relação Social entre os } \\
\text { usuários } \\
\text { As relações sociais existentes } \\
\text { entre os usuários são } \\
\text { consideradas no cálculo da } \\
\text { reputação pelo Histos. }\end{array}$ & $\begin{array}{l}\text { As instâncias desta classe têm pelo menos } \\
\text { uma associação através da propriedade } \\
\text { éEntrada com instâncias da classe Processo } \\
\text { Avaliação Reputação. }\end{array}$ \\
\hline $\begin{array}{c}\frac{\text { Evaluator }}{\text { Reputation }} \\
\text { ByHistosSporas }\end{array}$ & $\begin{array}{l}\text { Reputação do Avaliador } \\
\text { O valor da reputação do usuário } \\
\text { avaliador é considerado no } \\
\text { cálculo da reputação do alvo }\end{array}$ & $\begin{array}{l}\text { As instâncias desta classe têm pelo menos } \\
\text { uma associação através da propriedade } \\
\text { éEntrada com instâncias da classe Processo } \\
\text { Avaliação Reputação. }\end{array}$ \\
\hline
\end{tabular}

\subsubsection{Inferência das Respostas}

A figura 6.8 apresenta o diagrama da hierarquia que resultou do procedimento de inferência sobre a Ontologia Funcional de Reputação e as classes que representam os conceitos dos Sistemas Histos e Sporas.

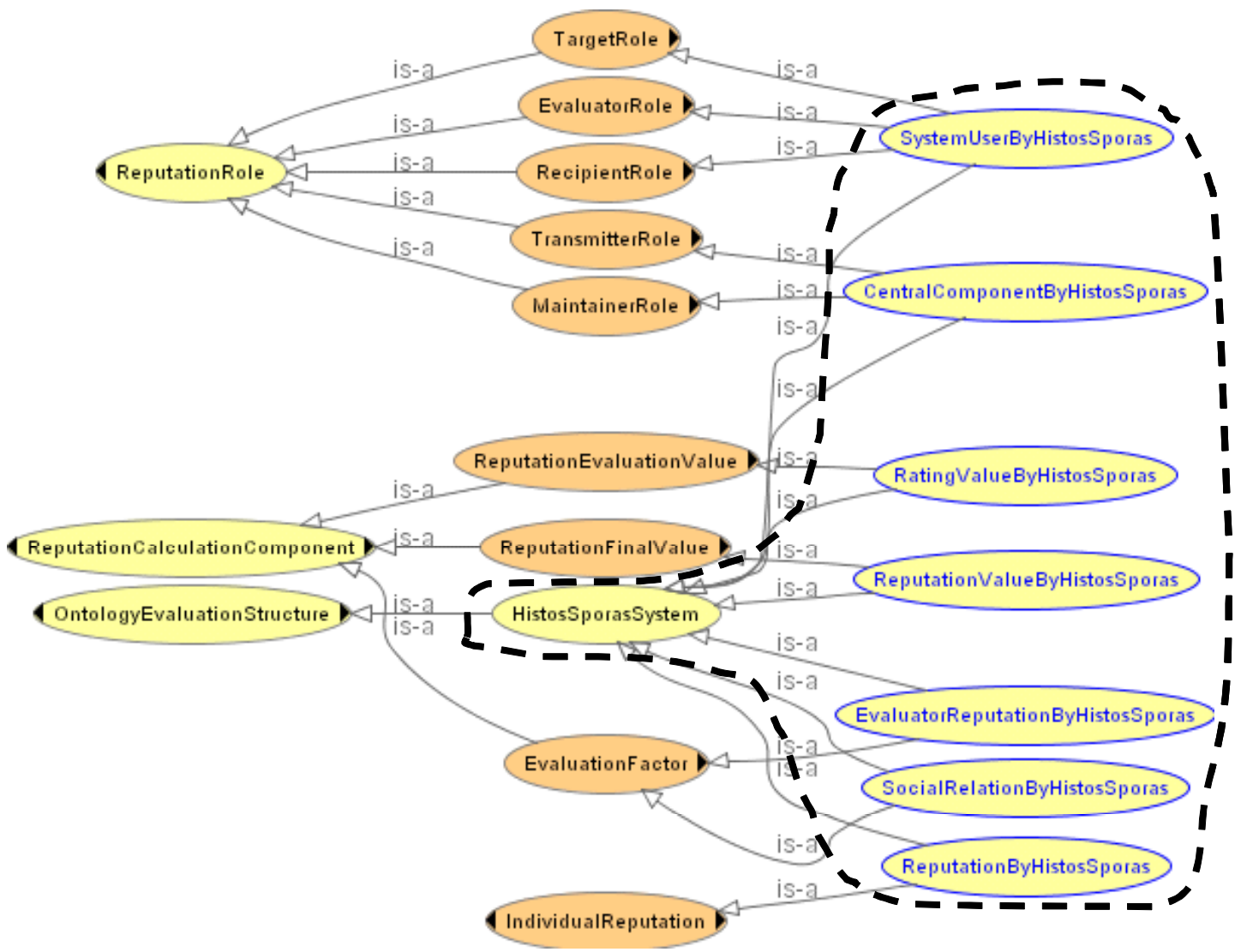

Figura 6.8: Diagrama da hierarquia inferida para as classes dos Sistemas Histos e Sporas (realçadas pela linha pontilhada), mostrando as superclasses a elas associadas pelo processo de subsunção 


\subsubsection{Discussão e Avaliação}

A ontologia ofereceu a expressividade necessária, e de forma consistente, para a representação de todos os conceitos dos Sistemas Histos e Sporas.

A classe ReputationByHistosSporas, que representa o conceito associado à natureza da reputação, foi subsumida pela classe IndividualReputation.

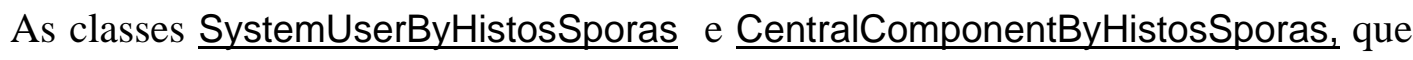
representam os conceitos Usuário do Sistema e Componente Central do Sistema, foram subsumidas pelas classes associadas aos papéis reputativos, EvaluatorRole e RecipientRole no primeiro caso, e MaintainerRole, TransmitterRole no último. Assim, foi possível separar o papel de avaliador, desempenhado pelo usuário que fornece a avaliação após a interação, do papel de mantenedor, desempenhado pelo componente central, que coleta e agrega as avaliações, gerando o valor da reputação. O papel de transmissor é desempenhado pelo componente central, visto que é o responsável pela difusão do valor da reputação, enquanto o papel de receptor é desempenhado pelo usuário do sistema.

A diferença entre as classes RatingValueByHistosSporas e ReputationValueByHistosSporas, correspondentes aos conceitos Valor da Avaliação e Valor da Reputação, foi expressa corretamente pela ontologia, visto que a subsunção identificou a primeira como subclasse de ReputationEvalutionValue e a segunda como subclasse de ReputationFinalValue.

Finalmente, foi possível identificar a função dos conceitos Relações Sociais e Reputação do Avaliador no cálculo da reputação, qual seja, eles estão entre os fatores considerados no processo de avaliação da reputação, pois as classes que os representam, SocialRelationByHistosSporas e EvaluatorReputationByHistosSporas, são subclasses de EvaluatorFactor.

\subsection{Avaliação Utilizando o Sistema de Reputação Baseado em Papel Social}

No Sistema de Reputação baseado em Papel Social proposto por Carter et al. (2002) (ver seção 2.2.5) a reputação individual depende da capacidade de um indivíduo em desempenhar seus papéis sociais no contexto de um sistema multiagentes de compartilhamento de informações. O valor da reputação de um indivíduo como usuário desse sistema é definida a partir do grau de satisfação de cada um dos papéis sociais por ele desempenhado. 


\subsubsection{Questões de Competência}

A classe ReputationBasedOnRoleSystem e suas subclasses foram definidas para representar as questões de competência relacionadas aos conceitos do Sistema de Reputação baseado em Papel Social. As subclasses contêm o sufixo ByRepBasedOnRole no nome.

A figura 6.9 mostra o diagrama das classes que representam estes conceitos.

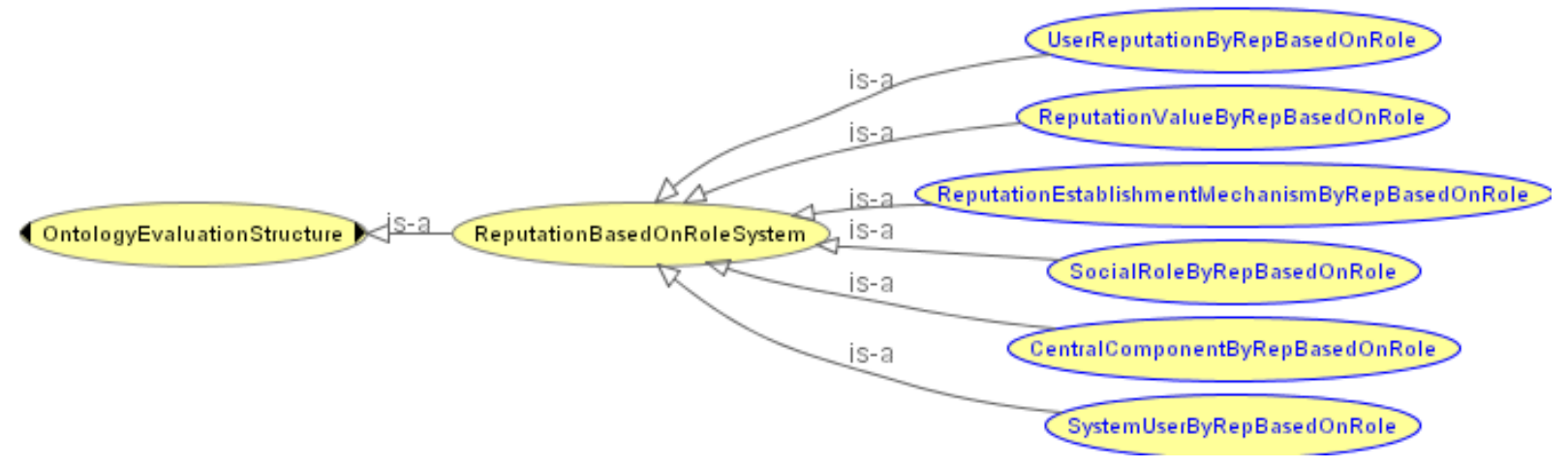

Figura 6.9: Diagrama das classes que representam os conceitos do Sistema de Reputação baseado em Papel Social

A tabela 6.4 mostra (i) os nomes das classes OWL DL definidas para representar os conceitos do Sistema de Reputação baseado em Papel Social, (ii) o nome e a definição de tais conceitos, a partir dos quais foram definidas as questões de competência, (iii) as descrições dessas questões usando os elementos da ontologia.

Tabela 6.4: Questões de competência e respectivas classes OWL DL para conceitos do Sistema de Reputação baseado em Papel Social

\begin{tabular}{|c|c|c|}
\hline $\begin{array}{l}\text { Classe em } \\
\text { OWL DL }\end{array}$ & $\begin{array}{c}\text { Conceitos do Sistema de } \\
\text { Reputação baseado em } \\
\text { Papel Social }\end{array}$ & $\begin{array}{c}\text { Descrição das questões em } \\
\text { termos ontológicos }\end{array}$ \\
\hline$\frac{\frac{\text { UserReputation }}{\text { ByRepBased }}}{\text { OnRole }}$ & \begin{tabular}{l}
\multicolumn{4}{c}{ Reputação do Usuário } \\
Usuários são os \\
utilizam indivíduos que \\
compartilhamento de informações.
\end{tabular} & $\begin{array}{l}\text { As instâncias desta classe têm pelo } \\
\text { menos uma associação através da } \\
\text { propriedade éNaturezaReputaçãoDe } \\
\text { com instâncias da classe Individuo }\end{array}$ \\
\hline$\frac{\frac{\text { SystemUser }}{\text { ByRepBased }}}{\text { OnRole }}$ & $\begin{array}{l}\quad \text { Usuário do Sistema } \\
\text { É o indivíduo ao qual o sistema } \\
\text { atribui uma reputação segundo o grau } \\
\text { de satisfação de seus papéis sociais. } \\
\text { Além de ter uma reputação, tal } \\
\text { indivíduo conhece a reputação dos } \\
\text { demais usuários. }\end{array}$ & $\begin{array}{l}\text { As instâncias desta classe têm pelo } \\
\text { menos uma associação através da } \\
\text { propriedade temReputação com } \\
\text { instâncias da classe Tipo De Reputação. } \\
\text { As instâncias desta classe têm pelo } \\
\text { menos uma associação através da } \\
\text { propriedade temProcessoReputativo } \\
\text { com instâncias das classes Processo } \\
\text { Recepção Reputação. }\end{array}$ \\
\hline
\end{tabular}




\begin{tabular}{|c|c|c|}
\hline $\begin{array}{l}\text { Classe em } \\
\text { OWL DL }\end{array}$ & $\begin{array}{c}\text { Conceitos do Sistema de } \\
\text { Reputação baseado em } \\
\text { Papel Social }\end{array}$ & $\begin{array}{l}\text { Descrição das questões em } \\
\text { termos ontológicos }\end{array}$ \\
\hline$\frac{\frac{\text { CentralComponen }}{\text { tByRepBased }}}{\text { OnRole }}$ & $\begin{array}{l}\text { Componente central do sistema } \\
\text { Responsável pela avaliação, cálculo, } \\
\text { manutenção e transmissão da } \\
\text { reputação dos usuários. }\end{array}$ & $\begin{array}{l}\text { As instâncias desta classe têm pelo } \\
\text { menos uma associação através da } \\
\text { propriedade temProcessoReputativo } \\
\text { com instâncias das classes Processo } \\
\text { Avaliação Reputação, Processo } \\
\text { Manutenção Reputação e Processo } \\
\text { Transmissão Reputação }\end{array}$ \\
\hline$\frac{\underline{\text { SocialRole }}}{\underline{\text { ByRepBased }}}$ & $\begin{array}{l}\text { Papel Social } \\
\text { É desempenhado pelos usuários do } \\
\text { sistema. A reputação de um usuário } \\
\text { depende da maneira como este } \\
\text { desempenha os seus papéis sociais. }\end{array}$ & $\begin{array}{l}\text { As instâncias desta classe têm pelo } \\
\text { menos uma associação através da } \\
\text { propriedade éEntrada com instâncias da } \\
\text { classe Processo Avaliação Reputação }\end{array}$ \\
\hline $\begin{array}{l}\frac{\frac{\text { Reputation }}{\text { Establishment }}}{\frac{\text { Mechanism }}{\text { ByRepBased }}} \\
\frac{\text { OnRole }}{\underline{\text { OnRole }}}\end{array}$ & $\begin{array}{l}\text { Mecanismo de Estabelecimento } \\
\qquad \text { da Reputação } \\
\text { É a parte do componente central do } \\
\text { sistema que gera a reputação de um } \\
\text { usuário. }\end{array}$ & $\begin{array}{l}\text { As instâncias desta classe têm pelo } \\
\text { menos uma associação através da } \\
\text { propriedade temSaida com instâncias } \\
\text { das classes Valor Avaliação Reputação } \\
\text { e Valor Final Reputação. }\end{array}$ \\
\hline$\frac{\frac{\text { ReputationValue }}{\text { ByRepBased }}}{\text { OnRole }}$ & $\begin{array}{l}\text { Valor da Reputação } \\
\text { Reflete o desempenho do usuário de } \\
\text { acordo com os papéis sociais, no } \\
\text { decorrer do tempo. }\end{array}$ & $\begin{array}{l}\text { As instâncias desta classe têm pelo } \\
\text { menos uma associação através da } \\
\text { propriedade éSaidaDe com instâncias } \\
\text { das classes Processo } \text { Avaliação } \\
\text { Reputação e Processo Manutenção } \\
\text { Reputação. }\end{array}$ \\
\hline
\end{tabular}

\subsubsection{Inferência das Respostas}

A figura 6.10 apresenta o diagrama da hierarquia que resultou do procedimento de inferência sobre a Ontologia Funcional de Reputação e as classes que representam os conceitos do Sistema de Reputação baseado em Papel Social. 


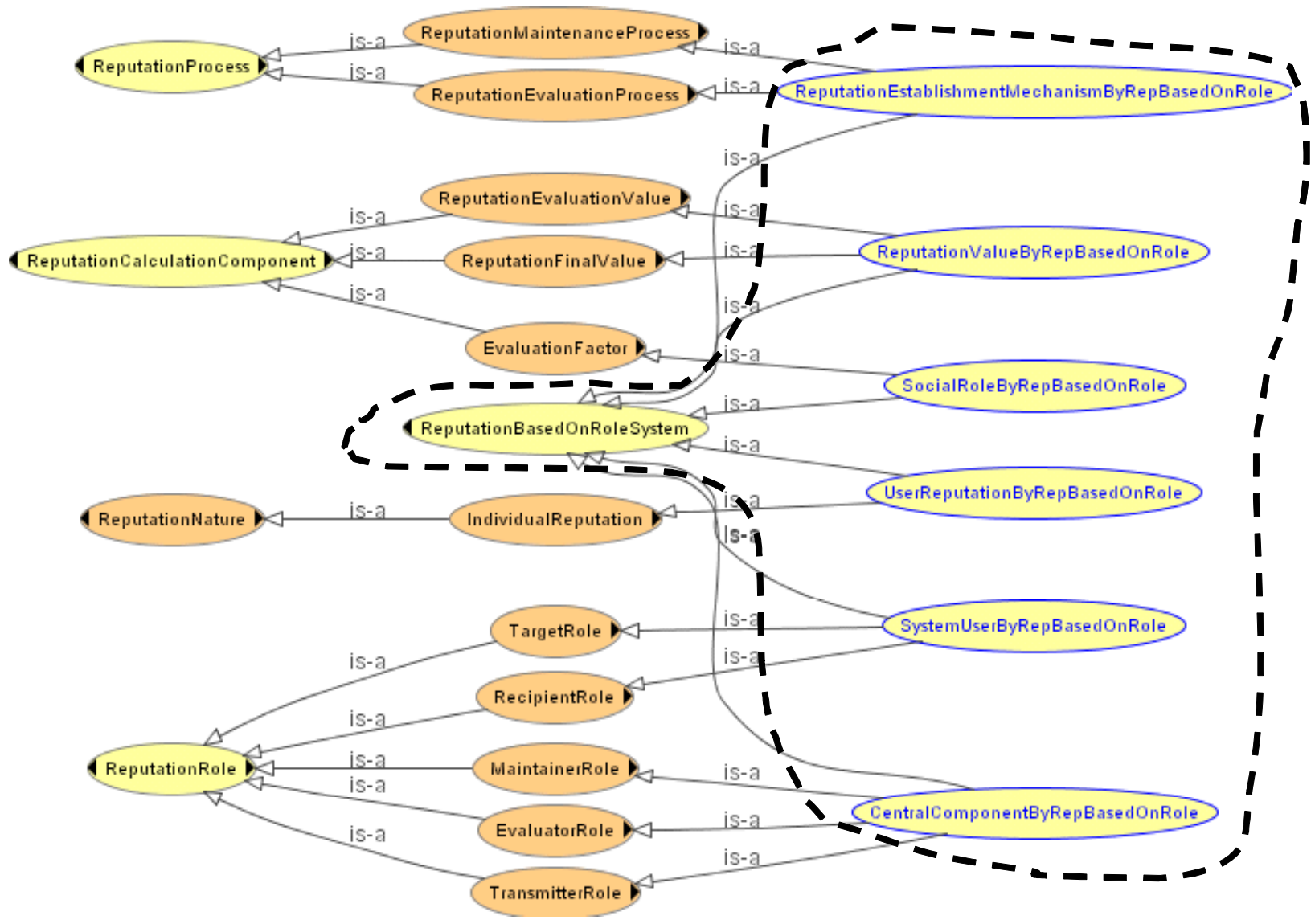

Figura 6.10: Diagrama da hierarquia inferida para as classes dos Sistemas de Reputação baseado em Papel Social (realçadas pela linha pontilhada), mostrando as superclasses a elas associadas pelo processo de subsunção

\subsubsection{Discussão e Avaliação}

A definição dos conceitos do Sistema de Reputação baseado em Papel Social foi realizada de forma consistente e com o grau de expressividade necessária a partir dos elementos da Ontologia Funcional de Reputação. Todas as classes que representam esses conceitos foram subsumidas pelas classes desta ontologia.

As classes SystemUserByRepBasedOnRole e CentralComponentByRepBasedOnRole, que representam respectivamente os conceitos Usuário do Sistema e Componente Central do Sistema, foram subsumidas pelas classes que representam os papéis reputativos, TargetRole e RecipientRole, no primeiro caso, e EvaluatorRole, MaintainerRole e TransmitterRole, no segundo.

Apesar da complexidade envolvida na definição do conceito Papel Social, representado pela classe SocialRoleByRepBasedOnRole, a ontologia permitiu expressá-lo corretamente no que concerne a sua funcionalidade, qual seja, trata-se de um fator de avaliação da reputação, pois a classe foi subsumida por EvaluatorFactor. Esse é um 
exemplo das vantagens de uma abordagem funcional tal como a adotada pela ontologia, visto que permite definir um conceito não pelo que ele é mas pelo que ele faz, possibilitando o reconhecimento de conceitos com funções similares, sem contudo terem a mesma natureza.

Finalmente, a classe ReputationEstablishmentMechanismByRepBasedOnRole, que representa o conceito Mecanismo de Estabelecimento da Reputação, foi subsumida pelas classes ReputationEvaluationProcess e ReputationMaintenanceProcess, enquanto a classe ReputationValueByRepBasedOnRole, que representa o conceito Valor da Reputação, foi subsumida pelas classes ReputationEvaluationValue e ReputationFinalValue. Este resultado mostra que foi possível expressar a dupla funcionalidade deste mecanismo, que é responsável tanto pela avaliação da reputação como pela manutenção da mesma, uma vez que considera os valores da reputação segundo uma perspectiva temporal.

\subsection{Avaliação Utilizando o Sistema de Reputação e Endosso}

No Sistema de Reputação e Endosso proposto por Maximilien e Singh (2002a, 2002b) (ver seção 2.2.6), a avaliação que um usuário faz de um serviço Web reflete a sua experiência com aquele serviço por meio de um conjunto de atributos e seus respectivos valores e relevâncias. Nesse sistema, a reputação de um serviço agrega as avaliações fornecidas pelos diversos usuários ao longo do tempo. Entretanto, essas avaliações não são consideradas como valores absolutos, e sim como uma função dos atributos envolvidos. Além dos agentes WSAP, que atuam como representante do usuário, a arquitetura de sistema multiagentes utiliza as agências de reputação e de endosso, que são responsáveis pela coleta e fornecimento de informações sobre a reputação de um serviço.

\subsubsection{Questões de Competência}

A classe ReputationAndEndorsementSystem e suas subclasses foram definidas para representar as questões de competência relacionadas aos conceitos do Sistema de Reputação e Endosso. As subclasses contêm o sufixo ByRES no nome.

A figura 6.11 mostra o diagrama das classes que representam estes conceitos. 


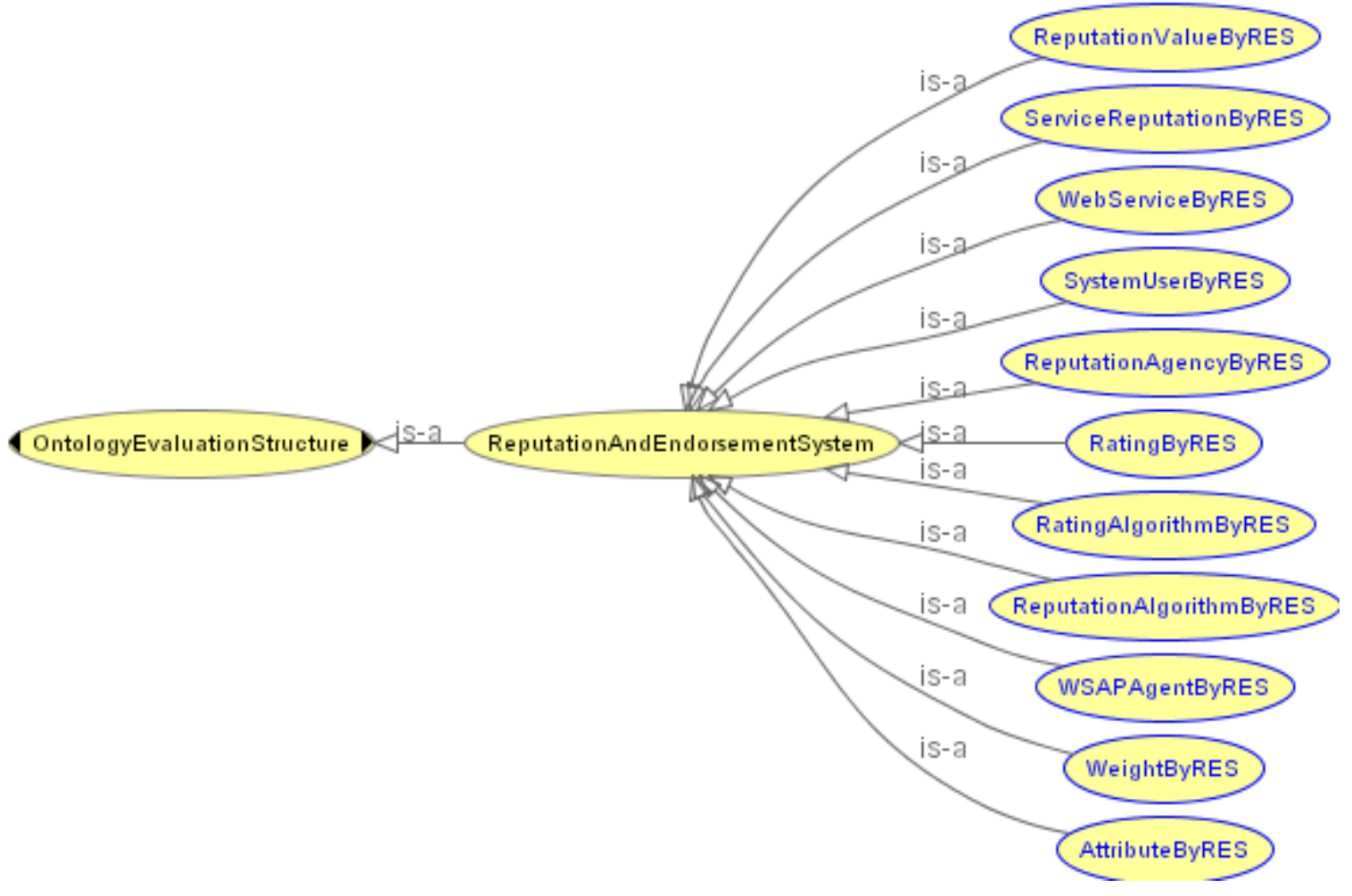

Figura 6.11: Diagrama das classes que representam os conceitos do Sistema de Reputação e Endosso

A tabela 6.5 mostra (i) os nomes das classes OWL DL definidas para representar os conceitos do Sistema de Reputação e Endosso, (ii) o nome e a definição de tais conceitos, a partir dos quais foram definidas as questões de competência, e (iii) as descrições dessas questões usando os elementos da ontologia.

Tabela 6.5: Questões de competência e respectivas classes OWL DL para conceitos do Sistema de Reputação e Endosso

\begin{tabular}{|c|c|c|}
\hline $\begin{array}{c}\text { Classe em } \\
\text { OWL DL }\end{array}$ & $\begin{array}{l}\text { Conceitos Sistema de } \\
\text { Reputação e Endosso }\end{array}$ & $\begin{array}{l}\text { Descrição das questões em } \\
\text { termos ontológicos }\end{array}$ \\
\hline $\begin{array}{c}\frac{\text { Service }}{\text { Reputation }} \\
\frac{\text { ByRES }}{\underline{\text { ByRE }}}\end{array}$ & $\begin{array}{l}\text { Reputação de Serviço } \\
\text { A reputação se aplica a um } \\
\text { serviço. }\end{array}$ & $\begin{array}{l}\text { As instâncias desta classe têm pelo menos } \\
\text { uma associação através da propriedade } \\
\text { éNaturezaReputaçãoDe com instâncias da } \\
\text { classe Serviço. }\end{array}$ \\
\hline$\frac{\text { WebService }}{\underline{\text { ByRES }}}$ & $\begin{array}{l}\text { Serviço Web } \\
\text { É o serviço avaliado pelo usuário } \\
\text { do sistema. }\end{array}$ & $\begin{array}{l}\text { As instâncias desta classe têm pelo menos } \\
\text { uma associação através da propriedade } \\
\text { temReputação com instâncias da classe } \\
\text { TipoReputação. }\end{array}$ \\
\hline$\frac{\text { SystemUser }}{\underline{\text { ByRES }}}$ & $\begin{array}{l}\text { Usuário do Sistema } \\
\text { O usuário do sistema avalia o } \\
\text { serviço a partir dos atributos do } \\
\text { mesmo. }\end{array}$ & $\begin{array}{l}\text { As instâncias desta classe têm pelo menos } \\
\text { uma associação através da propriedade } \\
\text { executaProcessoReputativo com instâncias } \\
\text { da classe Processo Avaliação Conteúdo } \\
\text { Reputação }\end{array}$ \\
\hline
\end{tabular}




\begin{tabular}{|c|c|c|}
\hline $\begin{array}{l}\text { Classe em } \\
\text { OWL DL }\end{array}$ & $\begin{array}{l}\text { Conceitos Sistema de } \\
\text { Reputação e Endosso }\end{array}$ & $\begin{array}{c}\text { Descrição das questões em } \\
\text { termos ontológicos }\end{array}$ \\
\hline$\frac{\text { WSAPAgent }}{\underline{\text { ByRES }}}$ & $\begin{array}{l}\text { Agente WSAP } \\
\text { Consultam e compartilham o seu } \\
\text { conhecimento com as agências de } \\
\text { reputação; recolhem a avaliação } \\
\text { do usuário após a utilização do } \\
\text { serviço e calculam a reputação. }\end{array}$ & $\begin{array}{l}\text { As instâncias desta classe têm pelo menos } \\
\text { uma associação através da propriedade } \\
\text { executaProcessoReputativo com instâncias } \\
\text { das classes Processo Transmissão } \\
\text { Reputação, Processo Recepção } \\
\text { Reputação, e Processo Manutenção } \\
\text { Reputação. }\end{array}$ \\
\hline$\frac{\frac{\text { Reputation }}{\text { Agency }}}{\text { ByRES }}$ & $\begin{array}{l}\text { Agência de Reputação } \\
\text { Coletam e fornecem os valores } \\
\text { dos diversos atributos que podem } \\
\text { compor a reputação de um serviço }\end{array}$ & $\begin{array}{l}\text { As instâncias desta classe têm pelo menos } \\
\text { uma associação através da propriedade } \\
\text { executaProcessoReputativo com instâncias } \\
\text { das classes Processo Transmissão } \\
\text { Reputação, e Processo Recepção } \\
\text { Reputação. }\end{array}$ \\
\hline$\frac{\text { Attribute }}{\text { ByRES }}$ & \begin{tabular}{l}
\multicolumn{1}{c|}{ Atributo } \\
É a característica considerada na \\
avaliação de um serviço, tal como \\
preço e qualidade.
\end{tabular} & $\begin{array}{l}\text { As instâncias desta classe têm pelo menos } \\
\text { uma associação através da propriedade } \\
\text { éDetalheDe com instâncias da classe } \\
\text { Processo Avaliação Conteúdo Reputação. }\end{array}$ \\
\hline$\frac{\text { Weight }}{\text { ByRES }}$ & $\begin{array}{c}\text { Peso } \\
\text { É o peso associado a um atributo. }\end{array}$ & $\begin{array}{l}\text { As instâncias desta classe têm pelo menos } \\
\text { uma associação através da propriedade } \\
\text { éPesoDe com instâncias da classe Atributo } \\
\text { Avaliação Reputação. }\end{array}$ \\
\hline$\frac{\frac{\text { Rating }}{\text { Algorithm }}}{\underline{\text { ByRES }}}$ & $\begin{array}{l}\quad \text { Algoritmo de Avaliação } \\
\text { Calcula a avaliação de um serviço } \\
\text { levando em conta os atributos do } \\
\text { mesmo. }\end{array}$ & $\begin{array}{l}\text { As instâncias desta classe têm pelo menos } \\
\text { uma associação através da propriedade } \\
\text { temDetalheEm com instâncias da classe } \\
\text { AtributoAvaliaçãoReputação. }\end{array}$ \\
\hline $\begin{array}{l}\text { Rating } \\
\text { ByRES }\end{array}$ & \begin{tabular}{|l|r|}
\multicolumn{3}{|c|}{ Avaliação } \\
Determinada pelo algoritmo de \\
avaliação, representa r uma \\
agregação dos valores dos \\
atributos.
\end{tabular} & $\begin{array}{l}\text { As instâncias desta classe têm pelo menos } \\
\text { uma associação através da propriedade } \\
\text { éSaídaDe com instâncias da classe } \\
\text { Processo Avaliação Conteúdo Reputação. }\end{array}$ \\
\hline$\frac{\frac{\text { Reputation }}{\text { Algorithm }}}{\underline{\text { ByRES }}}$ & $\begin{array}{l}\text { Algoritmo de Reputação } \\
\text { Agrega várias avaliações e os } \\
\text { respectivos históricos, gerando } \\
\text { uma reputação. }\end{array}$ & $\begin{array}{l}\text { As instâncias desta classe têm pelo menos } \\
\text { uma associação através da propriedade } \\
\text { temSaida com instâncias da classe } \\
\text { ValorFinalReputação. }\end{array}$ \\
\hline$\frac{\frac{\text { Reputation }}{\text { Value }}}{\underline{\text { ByRES }}}$ & $\begin{array}{l}\text { Reputação } \\
\text { É o resultado da agregação de } \\
\text { diversas avaliações de um } \\
\text { serviço. }\end{array}$ & $\begin{array}{l}\text { As instâncias desta classe têm pelo menos } \\
\text { uma associação através da propriedade } \\
\text { éSaídaDe com instâncias da classe } \\
\text { Processo Manutenção Reputação. }\end{array}$ \\
\hline
\end{tabular}

\subsubsection{Inferência das Respostas}

A figura 6.12 apresenta o diagrama da hierarquia de classes que resultou do procedimento de inferência sobre a Ontologia Funcional de Reputação e as classes que representam os conceitos do Sistema de Reputação e Endosso. 


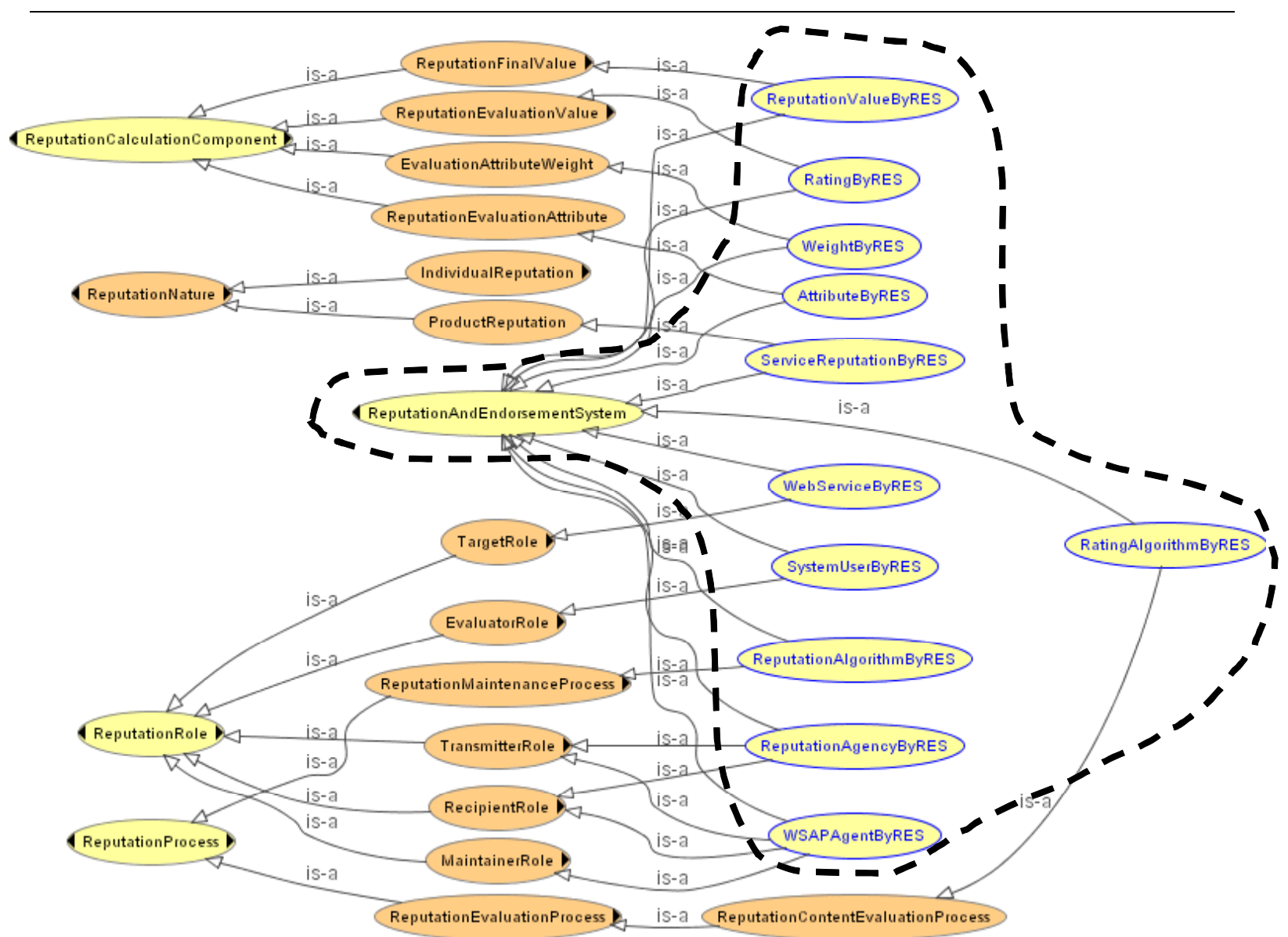

Figura 6.12: Diagrama da hierarquia inferida para as classes dos Sistemas de Reputação e Endosso (realçadas pela linha pontilhada), mostrando as superclasses a elas associadas pelo processo de subsunção

\subsubsection{Discussão e Avaliação}

A definição dos conceitos do Sistema de Reputação e Endosso foi realizada de forma consistente e com o grau de expressividade necessária a partir dos elementos da Ontologia Funcional de Reputação. Além disso, todas as classes que representam estes conceitos foram subsumidas pelas classes dessa ontologia.

A classe ServiceReputationByRES foi subsumida pela classe ProductReputation, indicando que se trata da reputação de um produto. Cabe ressaltar que tanto os serviços como os produtos estão associados à reputação de produto nesta ontologia.

Foi possível identificar os diversos papéis desempenhados pelas entidades envolvidas no sistema. O conceito Serviço Web é o alvo da reputação, já que a classe WebServiceByRES, que o representa, foi subsumida pela classe TargetRole. O conceito Usuário do Sistema desempenha o papel de avaliador, uma vez que a classe SystemUserByRES foi subsumida pela classe EvaluatorRole. Os papéis de transmissor e receptor são desempenhados tanto pelos Agentes WSAP como pela Agência de 
Reputação, visto que as classes WSAPAgentByRES e ReputationAgencyByRES foram ambas subsumidas pelas classes RecipientRole e TransmitterRole. Além disso, os Agentes WSAP desempenham o papel de mantenedores, pois a classe WSAPAgentByRES foi também subsumida pela classe MaintainerRole. Esta subsunção mostra que estes agentes são os responsáveis pela manutenção da reputação, calculando a reputação de um serviço a partir dos atributos escolhidos pelo usuário.

As classes que representam os conceitos envolvidos com a avaliação da reputação de um serviço Web foram subsumidas corretamente pela ontologia. Assim, AttributeByRES é subclasse de ReputationEvaluationAttribute, WeightByRES de ReputationEvaluationWeight, $\quad \underline{\text { ReputationAlgorithmByRES }}$ de ReputationMaintenanceProcess, RatingByRES de ReputationEvaluationValue, ReputationValueByRES de ReputationFinalValue e, finalmente, que

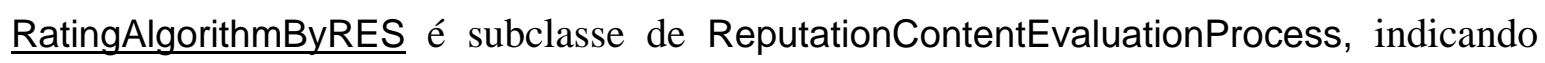
que o processo de avaliação utilizado é aquele que leva em consideração os atributos.

\subsection{Avaliação Utilizando o Sistema de Reputação e Confiança ReGret}

O Sistema de Reputação e Confiança ReGret (SABATER, 2003), descrito na seção 2.2.7, gera quatro avaliações de reputação distintas para um agente, chamadas de Confiança Direta (direct trust), Reputação de Testemunha (witness reputation), Reputação de Vizinhança (neighborhood reputation) e Reputação de Sistema (system reputation). Adicionalmente, este sistema usa a noção de credibilidade (credibility) do agente transmissor para medir a qualidade da informação recebida de terceiros.

\subsubsection{Questões de Competência}

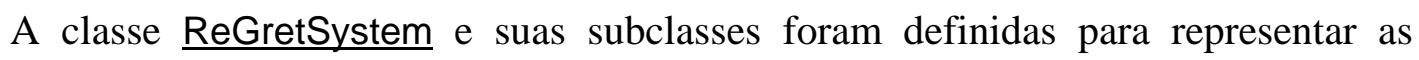
questões de competência relacionadas aos conceitos do Sistema ReGret. As subclasses contêm o sufixo ByRegret no nome.

A figura 6.13 mostra o diagrama das classes que representam estes conceitos. 


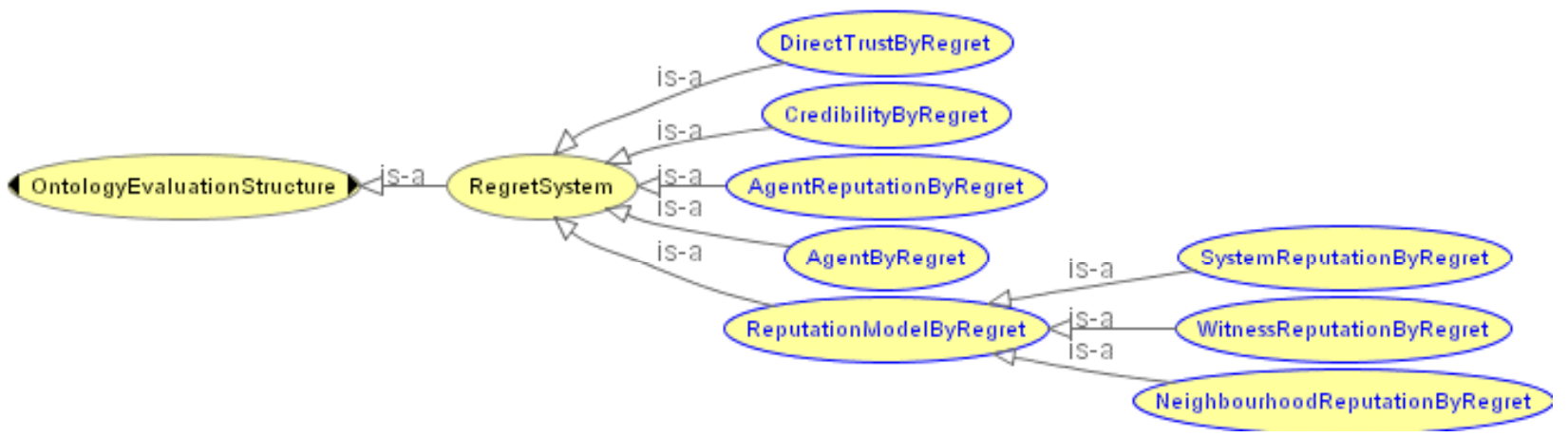

Figura 6.13: Diagrama das classes que representam os conceitos do Sistema ReGret

A tabela 6.6 mostra (i) os nomes das classes OWL DL definidas para representar os conceitos do Sistema ReGret, (ii) o nome e a definição de tais conceitos, a partir dos quais foram definidas as questões de competência, (iii) as descrições dessas questões usando os elementos da ontologia.

Tabela 6.6: Questões de competência e respectivas classes OWL DL para conceitos do Sistema ReGret

\begin{tabular}{|c|c|c|}
\hline $\begin{array}{l}\text { Classe em } \\
\text { OWL DL }\end{array}$ & Conceitos do Sistema ReGret & $\begin{array}{c}\text { Descrição das questões em } \\
\text { termos ontológicos }\end{array}$ \\
\hline $\begin{array}{c}\frac{\text { Agent }}{\text { Reputation }} \\
\text { ByRegret } \\
\text { By }\end{array}$ & $\begin{array}{l}\text { Reputação de Agente } \\
\text { A reputação se aplica a um agente. }\end{array}$ & $\begin{array}{l}\text { As instâncias desta classe têm pelo } \\
\text { menos uma associação através da } \\
\text { propriedade éNaturezaReputaçãoDe } \\
\text { com instâncias da classe Individuo }\end{array}$ \\
\hline$\frac{\text { Agent }}{\text { ByRegret }}$ & $\begin{array}{l}\text { Agente do Comércio Eletrônico } \\
\text { São os agentes que participam do } \\
\text { sistema de comércio eletrônico. Podem } \\
\text { ter uma reputação e são capazes de } \\
\text { calcular valores de reputação, transmitir } \\
\text { e receber informações de outros } \\
\text { agentes. }\end{array}$ & $\begin{array}{l}\text { As instâncias desta classe têm pelo } \\
\text { menos uma associação através da } \\
\text { propriedade temProcessoReputativo } \\
\text { com instâncias das classes Processo } \\
\text { Reputativo e através da propriedade } \\
\text { temReputação com a classe Tipo } \\
\text { Reputação }\end{array}$ \\
\hline$\frac{\text { DirectTrust }}{\text { ByRegret }}$ & $\begin{array}{l}\text { Confiança Direta } \\
\text { Refere-se à avaliação feita a partir de } \\
\text { interações diretas, incluindo tanto a } \\
\text { experiência direta como a observação } \\
\text { direta. }\end{array}$ & $\begin{array}{l}\text { As instâncias desta classe têm pelo } \\
\text { menos uma associação através da } \\
\text { propriedade temFonteInformação com } \\
\text { instâncias das classes Experiência } \\
\text { Direta ou Observação }\end{array}$ \\
\hline $\begin{array}{c}\frac{\text { Witness }}{\text { Reputation }} \\
\text { ByRegret }\end{array}$ & $\begin{array}{l}\text { Reputação de Testemunha } \\
\text { Reputação calculada por meio da } \\
\text { informação recebida dos agentes da } \\
\text { comunidade que tiveram experiência } \\
\text { direta com o agente alvo. }\end{array}$ & $\begin{array}{l}\text { As instâncias desta classe têm pelo } \\
\text { menos uma associação através da } \\
\text { propriedade temFonteInformação com } \\
\text { instâncias da classe Informação De } \\
\text { Terceiro }\end{array}$ \\
\hline$\frac{\text { NeighbourhoodR }}{\frac{\text { eputation }}{\text { ByRegret }}}$ & $\begin{array}{c}\text { Reputação de Vizinhança } \\
\text { Reputação baseada no preconceito. }\end{array}$ & $\begin{array}{l}\text { As instâncias desta classe têm pelo } \\
\text { menos uma associação através da } \\
\text { propriedade temFonteInformação com } \\
\text { instâncias da classe Preconceito. }\end{array}$ \\
\hline
\end{tabular}




\begin{tabular}{|c|c|c|}
\hline $\begin{array}{c}\text { Classe em } \\
\text { OWL DL }\end{array}$ & Conceitos do Sistema ReGret & $\begin{array}{c}\text { Descrição das questões em } \\
\text { termos ontológicos }\end{array}$ \\
\hline $\begin{array}{c}\frac{\text { System }}{\text { Reputation }} \\
\text { ByRegret }\end{array}$ & $\begin{array}{l}\text { Reputação de Sistema } \\
\text { Reputação baseada nas relações de } \\
\text { grupo do agente. }\end{array}$ & $\begin{array}{l}\text { As instâncias desta classe têm pelo } \\
\text { menos uma associação através da } \\
\text { propriedade temFontelnformação com } \\
\text { instâncias da classe Herança de Grupo. }\end{array}$ \\
\hline$\frac{\text { Credibility }}{\text { ByRegret }}$ & $\begin{array}{l}\text { Credibilidade } \\
\text { É a credibilidade da testemunha, } \\
\text { afetando a maneira como a informação } \\
\text { recebida será considerada no cálculo da } \\
\text { reputação. }\end{array}$ & $\begin{array}{l}\text { As instâncias desta classe têm pelo } \\
\text { menos uma associação através da } \\
\text { propriedade éEntradaDe com instâncias } \\
\text { da classe Processo Avaliação } \\
\text { Reputação. }\end{array}$ \\
\hline
\end{tabular}

\subsubsection{Inferência das Respostas}

A figura 6.14 apresenta o diagrama da hierarquia de classes que resultou do procedimento de inferência sobre a Ontologia Funcional de Reputação e as classes que representam os conceitos do Sistema ReGret.

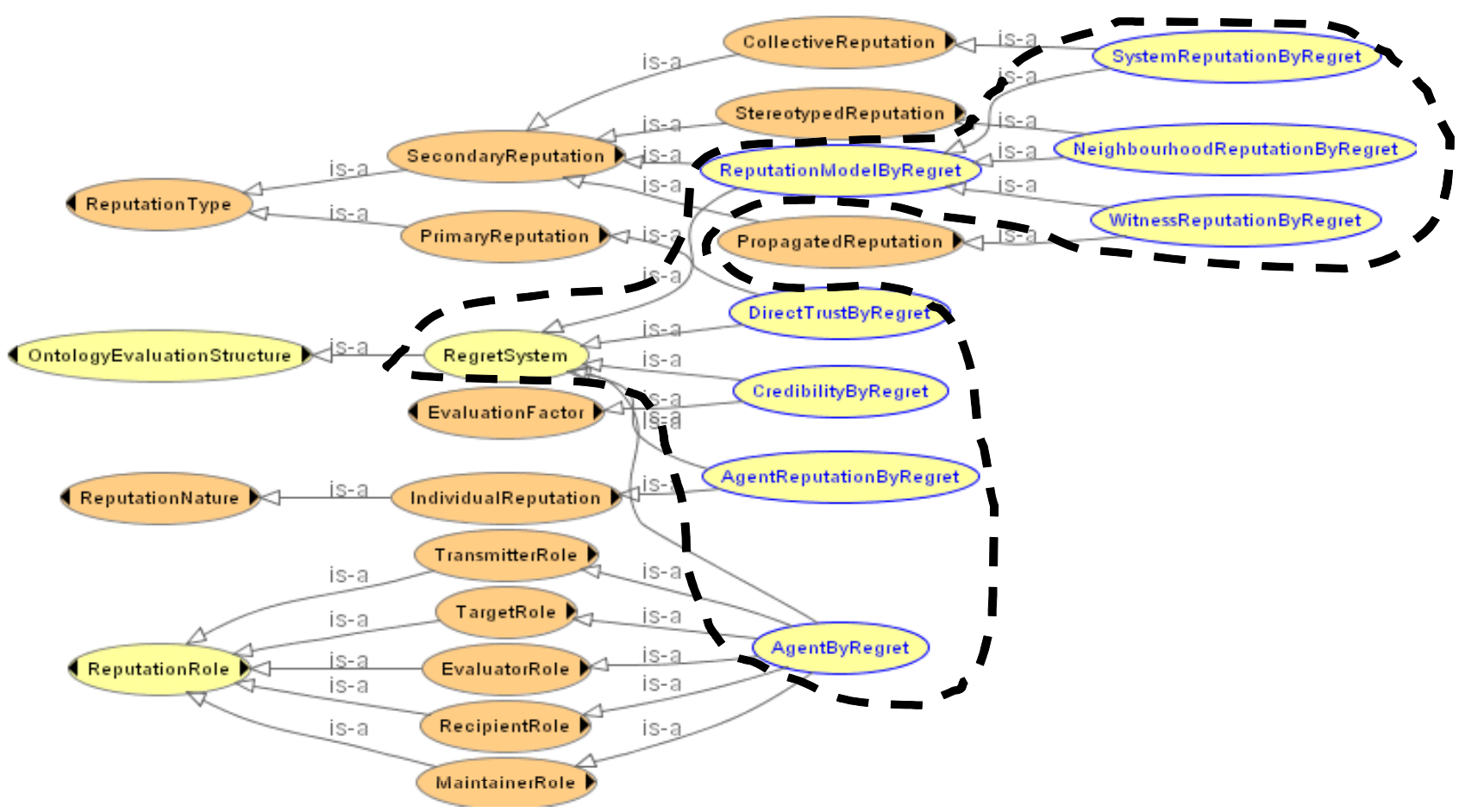

Figura 6.14: Diagrama da hierarquia inferida para as classes dos Sistemas ReGret (realçadas pela linha pontilhada), mostrando as superclasses a elas associadas pelo processo de subsunção

\subsubsection{Discussão e Avaliação}

Todas as classes que representam os conceitos do Sistema ReGret foram subsumidas pelas classes da Ontologia Funcional de Reputação. A definição da maior parte destes conceitos foi realizada de forma consistente e com o grau de expressividade 
necessária a partir dos elementos desta ontologia. A exceção consiste no conceito Reputação de Testemunha, discutido a seguir.

A classe AgentReputationByRegret, que representa o conceito Reputação de Agente, foi subsumida pela classe IndividualReputation, indicando que o conceito descreve uma reputação de indivíduo.

A classe AgentByRegret, que representa o conceito Agente do Comercio Eletrônico, foi subsumida pelas cinco classes da ontologia que representam os papéis reputativos, nomeadamente, TargetRole, EvaluatorRole, RecipientRole, TransmitterRole e MaintainerRole. Esse resultado indica que o agente pode desempenhar todos os papéis reputativos previstos pela ontologia, visto ser o alvo da reputação e o responsável pela avaliação, manutenção, transmissão e recepção da mesma.

As classes que representam os conceitos envolvidos com os diversos tipos de reputação foram subsumidas corretamente pela ontologia. Assim, DirectTrustByRegret é subclasse de PrimaryReputation, WitnessReputationByRegret de PropagatedReputation, NeighbourhoodReputationByRegret de StereotypedReputation e SystemReputationByRegret de CollectiveReputation. Entretanto, a definição do conceito Reputação de Testemunha em termos ontológicos não corresponde exatamente à sua definição original, a qual especifica que a fonte da reputação é a informação de terceiros que tiveram contato direto com o agente alvo, e não outros tipos de informação, tal como aquilo que o agente informante ouviu dizer. A ontologia não oferece a expressividade necessária para a definição deste conceito, expressando uma noção mais genérica que a noção original, qual seja, trata-se da reputação que resulta das informações recebidas de terceiros. Entretanto, as definições das classes SecondHandInformation ${ }^{33}$ e PropagatedReputation $^{34}$ foram mantidas, porque se avaliou que o refinamento necessário, qual seja, a especificação dos níveis da informação, tal como de segunda mão ou de terceira mão, traria como desvantagem a dificuldade de identificação desses níveis de informação em uma sociedade de agentes.

A classe CredibilityByRegret, que representa o conceito Credibilidade, foi subsumida pela classe EvaluationFactor. Segundo a definição do autor (SABATER, 2003, p. 51 e 53), este conceito é resultado de dois métodos distintos de avaliação de

\footnotetext{
33 Informação De Terceiro, uma das subclasses de Fonte Informação (ver seção 5.4.2.1)

${ }^{34}$ Reputação Propagada, uma das subclasses de Reputação Secundária (ver seção 5.4.1.1.3)
} 
credibilidade. O primeiro está baseado nas relações sociais existentes entre os agentes (avaliador, testemunha e alvo), enquanto o segundo depende da veracidade das informações fornecidas anteriormente pela testemunha. A ontologia permitiu representar este conceito de maneira funcional, definindo não o que ele é, mas para que serve, ou seja, a credibilidade é algo que atua como um fator considerado durante o processo de avaliação da reputação.

Esta abordagem funcional permitiu manter a ontologia em um nível de detalhe adequado, sem a necessidade de representar as diversas relações sociais e a análise de veracidade das informações recebidas e, entretanto, conservando a expressividade no que concerne à função do conceito. Cabe ressaltar que a perspectiva funcional adotada foi de grande valia em casos como este, em que a definição do que é o conceito é complexa, enquanto a definição do que o conceito faz é mais simples.

\subsection{Sumário da Avaliação da Ontologia}

A tabela 6.7 apresenta um sumário das respostas obtidas para as questões de competência durante a fase de avaliação da Ontologia Funcional de Reputação. Nesta tabela, as questões de competência estão organizadas da mesma maneira que na tabela 5.1 da seção 5.3.2, que definiu o escopo da ontologia. As respostas às questões de competência estão representadas em negrito, abaixo das respectivas questões.

Tabela 6.7: Sumário das respostas às questões de competência segundo os modelos e sistemas de reputação por critérios de análise

\begin{tabular}{|c|c|c|c|c|c|}
\hline $\begin{array}{l}\text { Critério } \\
\text { Modela } \\
\text { Sistema }\end{array}$ & Natureza & Papel & $\begin{array}{c}\text { Tipo de } \\
\text { Reputação }\end{array}$ & $\begin{array}{l}\text { Valor e Fator de } \\
\text { Avaliação }\end{array}$ & $\begin{array}{c}\text { Manutenção e } \\
\text { Distribuição }\end{array}$ \\
\hline $\begin{array}{c}\text { Modelo } \\
\text { Cognitivo } \\
\text { de } \\
\text { Reputação }\end{array}$ & $\begin{array}{c}\text { Qual é a } \\
\text { natureza } \\
\text { da } \\
\text { reputação? } \\
\text { Reputação } \\
\text { Individual }\end{array}$ & $\begin{array}{c}\text { Qual é o papel } \\
\text { desempenhado } \\
\text { pelo conjunto } \\
\text { de agentes } \\
\text { alvo? } \\
\text { Papel Alvo. } \\
\text { E pelos agentes } \\
\text { avaliadores? } \\
\text { Papel } \\
\text { Avaliador. } \\
\text { E pelos agentes } \\
\text { transmissores? } \\
\text { Papel } \\
\text { Transmissor. } \\
\text { E pelos agentes } \\
\text { beneficiários? } \\
\text { Sem resposta. }\end{array}$ & $\begin{array}{c}\text { O que é a Imagem? } \\
\text { Reputação Primária. } \\
\text { O que é a reputação? } \\
\text { Reputação } \\
\text { Secundária. }\end{array}$ & & $\begin{array}{l}\text { O que são os } \\
\text { aspectos } \\
\text { envolvidos na } \\
\text { transmissão da } \\
\text { reputação? } \\
\text { Componente de } \\
\text { Propagação da } \\
\text { Reputação } \\
\text { e } \\
\text { Papel Receptor. }\end{array}$ \\
\hline
\end{tabular}




\begin{tabular}{|c|c|c|c|c|c|}
\hline $\begin{array}{l}\text { Critério } \\
\text { Modela } \\
\text { Sistema }\end{array}$ & Natureza & Papel & $\begin{array}{c}\text { Tipo de } \\
\text { Reputação }\end{array}$ & $\begin{array}{l}\text { Valor e Fator de } \\
\text { Avaliação }\end{array}$ & $\begin{array}{c}\text { Manutenção e } \\
\text { Distribuição }\end{array}$ \\
\hline $\begin{array}{c}\text { Modelo } \\
\text { Tipologia } \\
\text { de } \\
\text { Reputação }\end{array}$ & $\begin{array}{c}\text { Qual é a } \\
\text { natureza } \\
\text { da } \\
\text { reputação? } \\
\text { Reputação } \\
\text { Individual } \\
\text { e } \\
\text { Reputação } \\
\text { Grupo. }\end{array}$ & & $\begin{array}{c}\text { O que são: a } \\
\text { reputação direta, a de } \\
\text { interação, a } \\
\text { observada, a indireta, } \\
\text { a derivada anterior, a } \\
\text { derivada de grupo e a } \\
\text { propagada? } \\
\text { Reputação Primária, } \\
\text { Reputação } \\
\text { Secundária e } \\
\text { subclasses }\end{array}$ & & \\
\hline $\begin{array}{c}\text { Sistemas } \\
\text { Histos e } \\
\text { Sporas }\end{array}$ & $\begin{array}{c}\text { Qual é a } \\
\text { natureza } \\
\text { da } \\
\text { reputação } \\
\text { do usuário } \\
\text { do } \\
\text { sistema? } \\
\text { Reputação } \\
\text { Individual }\end{array}$ & $\begin{array}{l}\text { Qual o papel } \\
\text { desempenhado } \\
\text { pelos usuários } \\
\text { do sistema? } \\
\text { Alvo, Avaliador } \\
\text { e Receptor. }\end{array}$ & & $\begin{array}{l}\text { O que é a avaliação da } \\
\text { reputação? } \\
\text { Valor Avaliação } \\
\text { Reputação } \\
\text { O que é o valor da } \\
\text { reputação? } \\
\text { Valor Final Reputação. } \\
\text { O que é relação social? } \\
\text { Fator de Avaliação } \\
\text { Reputação } \\
\text { O que é a reputação do } \\
\text { avaliador? } \\
\text { Fator de Avaliação } \\
\text { Reputação }\end{array}$ & $\begin{array}{l}\text { O que faz o } \\
\text { componente } \\
\text { central do } \\
\text { sistema? } \\
\text { Mantenedor e } \\
\text { Transmissor. }\end{array}$ \\
\hline $\begin{array}{l}\text { Sistema } \\
\text { Reputação } \\
\text { cl papéis }\end{array}$ & $\begin{array}{c}\text { Qual é a } \\
\text { natureza } \\
\text { da } \\
\text { reputação } \\
\text { do usuário } \\
\text { do } \\
\text { sistema? } \\
\text { Reputação } \\
\text { Individual }\end{array}$ & $\begin{array}{l}\text { Qual é o papel } \\
\text { desempenhado } \\
\text { pelos usuários } \\
\text { do sistema? } \\
\text { Alvo, Receptor. }\end{array}$ & & $\begin{array}{l}\text { O que é o valor da } \\
\text { reputação? } \\
\text { Valor Avaliação e } \\
\text { Valor Final da } \\
\text { Reputação. } \\
\text { O que é o papel social? } \\
\text { Fator Avaliação } \\
\text { Reputação }\end{array}$ & $\begin{array}{c}\text { O que faz o } \\
\text { componente } \\
\text { central do } \\
\text { sistema? } \\
\text { Avaliador, } \\
\text { Mantenedor, } \\
\text { Transmissor. } \\
\text { O que é o } \\
\text { estabelecimento } \\
\text { da reputação? } \\
\text { Processo de } \\
\text { Avaliação da } \\
\text { Reputação e } \\
\text { Processo de } \\
\text { Manutenção da } \\
\text { Reputação. }\end{array}$ \\
\hline
\end{tabular}




\begin{tabular}{|c|c|c|c|c|c|}
\hline $\begin{array}{l}\text { Critério } \\
\text { Modela } \\
\text { Sistema }\end{array}$ & Natureza & Papel & $\begin{array}{c}\text { Tipo de } \\
\text { Reputação }\end{array}$ & $\begin{array}{l}\text { Valor e Fator de } \\
\text { Avaliação }\end{array}$ & $\begin{array}{c}\text { Manutenção e } \\
\text { Distribuição }\end{array}$ \\
\hline $\begin{array}{c}\text { Sistema } \\
\text { de } \\
\text { Reputação } \\
\text { e Endosso }\end{array}$ & $\begin{array}{c}\text { Qual é a } \\
\text { natureza } \\
\text { da } \\
\text { reputação } \\
\text { do serviço } \\
\text { Web? } \\
\text { Reputação } \\
\text { de } \\
\text { Produto }\end{array}$ & $\begin{array}{c}\text { Qual é o papel } \\
\text { desempenhado } \\
\text { pelo serviço } \\
\text { Web? Alvo. } \\
\text { E pelo usuário? } \\
\text { Avaliador. } \\
\text { E pelo agente } \\
\text { WSAP? } \\
\text { Transmissor e } \\
\text { Receptor e } \\
\text { Mantenedor. }\end{array}$ & & $\begin{array}{c}\text { O que é o algoritmo de } \\
\text { avaliação? Processo } \\
\text { Avaliação Conteúdo } \\
\text { Reputação. } \\
\text { O que é a avaliação do } \\
\text { serviço? } \\
\text { Valor Avaliação } \\
\text { Reputação. } \\
\text { O que é o valor da } \\
\text { reputação? } \\
\text { Valor Final Reputação. } \\
\text { O que é o atributo? } \\
\text { Atributo Avaliação } \\
\text { Reputação } \\
\text { O que é o peso? } \\
\text { Relevância Atributo } \\
\text { Avaliação Reputação. }\end{array}$ & $\begin{array}{l}\text { O que fazem as } \\
\text { agências de } \\
\text { reputação? } \\
\text { Transmissor e } \\
\text { Receptor. } \\
\text { O que é } \\
\text { algoritmo de } \\
\text { reputação? } \\
\text { Processo } \\
\text { Manutenção } \\
\text { Reputação. }\end{array}$ \\
\hline $\begin{array}{l}\text { Sistema } \\
\text { Regret }\end{array}$ & $\begin{array}{c}\text { Qual é a } \\
\text { natureza } \\
\text { da } \\
\text { reputação } \\
\text { do agente? } \\
\text { Reputação } \\
\text { Individual. }\end{array}$ & $\begin{array}{l}\text { Qual é o papel } \\
\text { do usuário do } \\
\text { comércio } \\
\text { eletrônico? } \\
\text { Alvo, } \\
\text { Avaliador, } \\
\text { Mantenedor, } \\
\text { Receptor, } \\
\text { Transmissor }\end{array}$ & $\begin{array}{l}\text { O que é a confiança } \\
\text { direta? } \\
\text { Reputação Primária. } \\
\text { O que é a reputação } \\
\text { de testemunha? } \\
\text { Reputação } \\
\text { Propagada. } \\
\text { O que é a reputação } \\
\text { de vizinhança? } \\
\text { Reputação a Priori. } \\
\text { O que é a reputação } \\
\text { de sistema? } \\
\text { Reputação } \\
\text { Coletiva. }\end{array}$ & $\begin{array}{l}\text { Qual é a função da } \\
\text { credibilidade? } \\
\text { Fator avaliação } \\
\text { Reputação. }\end{array}$ & \\
\hline
\end{tabular}

\subsection{Considerações Finais}

Este capítulo apresentou os resultados da fase de avaliação da Ontologia Funcional de Reputação. O procedimento utilizado para essa avaliação foi baseado na metodologia para construção e avaliação de ontologias proposta por Uschold e Gruninger (1996), e foi realizado a partir das questões de competência que delimitaram o escopo da ontologia. Inicialmente as questões de competência foram formuladas em OWL DL. Em seguida, a ontologia foi classificada pelo motor de inferência RACER. Esta classificação produziu as respostas às questões de competência, através da subsunção das classes que representam essas questões em classes da ontologia. Finalmente, o resultado deste processo de classificação foi analisado e discutido. 
A ontologia ofereceu o grau de expressividade necessária, e de forma consistente, para a definição da maior parte das questões de competência propostas como escopo da ontologia. A principal exceção consistiu na noção de conjunto de agentes beneficiários que faz parte do Modelo Cognitivo de Reputação (CONTE e PAOLUCCI, 2002). Este conceito, que está relacionado à noção de objetivo do agente, envolve a definição de conceitos sobre cognição e estados mentais, como crença (belief), desejo (desire) e intenção (intention) (RAO e GEORGEFF, 1995).

A avaliação dos modelos e sistemas de reputação facilitou o entendimento dos diversos componentes neles envolvidos. Esta avaliação mostrou que a Ontologia Funcional de Reputação pode ser usada como uma interlingua entre estes modelos e sistemas de reputação, pois permitiu identificar conceitos similares com nomes distintos, tais como os conceitos Imagem (CONTE e PAOLUCCI, 2002) e Reputação Direta (MUI et al., 2002a), que representam ambos a reputação que resulta das experiências prévias do agente avaliador com o alvo da reputação.

Finalmente, a perspectiva funcional adotada na ontologia possibilitou o reconhecimento de conceitos com funções similares sem, contudo, ter natureza similar. Assim, apesar da complexidade inerente aos conceitos dos modelos analisados, como a noção de Papel Social no Sistema de Reputação baseado em Papéis (CARTER et al., 2002), a noção de Relação Social entre os usuários em Histos e Sporas (ZACHARIA e MAES, 2000), e a noção de Credibilidade no sistema ReGret (SABATER, 2003), foi possível representar estes conceitos na ontologia e identificar a similaridade de funções entre eles. 


\section{Conclusões}

Este trabalho propôs uma Ontologia Funcional de Reputação, que tem como objetivo oferecer uma perspectiva funcional para a representação e análise da reputação como mecanismo de controle social em sociedades de agentes, de forma a sustentar a implementação de sistemas de reputação. A perspectiva funcional adotada consiste em considerar que os conceitos que compõem a ontologia são agrupados em categorias, de acordo com a sua função no mecanismo de controle social.

A Ontologia Funcional de Reputação é composta por cinco categorias de conhecimento: Conhecimento Reputativo, Conhecimento de Senso Comum, Conhecimento do Mundo, Conhecimento Normativo e Conhecimento de Responsabilidade. Com exceção da primeira, que foi totalmente desenvolvida neste trabalho, as outras categorias foram propostas pela Ontologia Funcional do Direito (VALENTE, 1995) e incorporadas à Ontologia Funcional de Reputação através das três extensões:

- a ampliação do conceito de norma jurídica em norma social;

- a substituição da reação jurídica (sanção ou compensação) pela reação social (má reputação ou boa reputação);

- a interiorização do mecanismo de controle social, que passa a existir na 'mente' do agente e não mais como instituição jurídica externa a ele.

\subsection{Contribuições}

Apesar da complexidade inerente ao tema abordado, qual seja, a identificação e representação dos aspectos envolvidos na noção de reputação, foi possível propor neste trabalho uma Ontologia Funcional de Reputação que representa grande parte do conhecimento disponível sobre o tema. Cabe ressaltar que essa complexidade advém da ausência, mesmo no campo das Ciências Humanas, de um quadro teórico completo que dê conta de todos os aspectos envolvidos na noção de reputação (FERRIS et al., 2003).

Em linhas gerais, a principal contribuição desse trabalho consiste em propor uma perspectiva funcional para a representação e a análise da reputação como mecanismo de controle social em sociedades de agentes, por meio de uma Ontologia Funcional de 
Reputação. Os objetivos dessa ontologia, propostos na seção 1.2, foram atingidos totalmente, da seguinte forma:

1. Representar o conhecimento sobre reputação - A Ontologia Funcional de Reputação proposta representa uma grande parte do conhecimento científico sobre reputação, por meio de uma das cinco categorias de conhecimento que a compõem, a categoria de Conhecimento Reputativo. Esta categoria, que forma o núcleo da ontologia, é composta por quarenta e cinco conceitos, coletados a partir dos diversos aspectos da noção de reputação identificados tanto em Ciências Humanas quanto nos trabalhos em IA;

2. Ilustrar o uso da reputação para controle social - A ilustração de como a reputação pode ser usada como parte de um mecanismo de controle social, baseado em Valente (1995), pode ser assim descrita:

a. A categoria Conhecimento do Mundo descreve o comportamento do agente em termos de casos, de forma que esse comportamento possa ser interpretado pelas demais categorias da ontologia;

b. A partir dessa descrição, o Conhecimento Normativo classifica o caso, por meio de um status normativo, de acordo com as normas sociais vigentes;

c. O Conhecimento de Responsabilidade então define se o agente deve ser considerado responsável pelo comportamento apresentado (confirmação de responsabilidade) ou não (restrição de responsabilidade);

d. A partir do status normativo e da confirmação da responsabilidade do agente no caso, o Conhecimento Reputativo é capaz de definir a reputação do agente, como uma forma de recompensa (boa reputação) ou penalidade (reputação ruim) pelo seu comportamento.

3. Funcionar como uma interlingua - A ontologia pode ser usada como uma interlingua na comparação dos diversos modelos e sistemas de reputação, de forma a mitigar a ausência de padrão entre os diversos modelos computacionais existentes. Um exemplo desta funcionalidade foi apresentado na fase de avaliação da ontologia, que proporcionou uma espécie de tradutor de termos usados pelos modelos de reputação. Foi possível reconhecer que a noção que o Modelo Cognitivo de Reputação (CONTE e PAOLUCCI, 2002) chama de Imagem, o Sistema ReGret (SABATER, 2003) nomeia de Confiança Direta e a 
Tipologia de Reputação (MUI et al., 2002a) denomina de Reputação Direta. A tabela 7.1 sumariza o resultado da comparação entre estes modelos em relação ao termo usado para nomear a reputação de acordo com a fonte de informação utilizada.

Tabela 7.1: Exemplo da comparação entre termos utilizados pelos modelos de reputação

\begin{tabular}{|c|c|c|c|}
\hline $\begin{array}{c}\text { Ontologia } \\
\text { Funcional de } \\
\text { Reputação }\end{array}$ & $\begin{array}{c}\text { Modelo } \\
\text { Cognitivo de } \\
\text { Reputação } \\
\end{array}$ & $\begin{array}{c}\text { Modelo Tipologia } \\
\text { de Reputação }\end{array}$ & Sistema ReGret \\
\hline Reputação Primária & Imagem & Reputação Direta & Confiança Direta \\
\hline Reputação Secundária & Reputação & $\begin{array}{l}\text { Reputação } \\
\text { Indireta }\end{array}$ & \\
\hline Reputação Propagada & & $\begin{array}{l}\text { Reputação } \\
\text { Propagada }\end{array}$ & $\begin{array}{l}\text { Reputação de } \\
\text { Testemunha }\end{array}$ \\
\hline Reputação Coletiva & & $\begin{array}{c}\text { Reputação } \\
\text { Derivada de Grupo }\end{array}$ & $\begin{array}{c}\text { Reputação de } \\
\text { Sistema }\end{array}$ \\
\hline Reputação a Priori & & $\begin{array}{c}\text { Reputação } \\
\text { Derivada Anterior }\end{array}$ & $\begin{array}{l}\text { Reputação de } \\
\text { Vizinhança }\end{array}$ \\
\hline
\end{tabular}

\subsection{Trabalhos Futuros}

No decorrer deste trabalho surgiram algumas questões que não foram tratadas devido à delimitação do escopo inicialmente proposto. Estas questões, que apresentam os principais temas de continuação considerados para este trabalho, são as seguintes:

- Extensão da ontologia, a fim de incorporar os conceitos relativos à noção de confiança. Para isso, é preciso tanto ampliar a análise dos modelos de confiança propostos pela IA como buscar um quadro conceitual para essa noção na área de Ciências Humanas;

- Avaliação de possível utilização das categorias de Conhecimento MetaJurídico e Conhecimento Criativo, propostas por Valente (1995) mas não incorporadas à Ontologia Funcional de Reputação, como mecanismo para modelar agentes capazes de alterar as regras que usam para calcular a reputação;

- Detalhamento do estudo realizado sobre a utilização da Ontologia Funcional de Reputação como parte do nível semântico de integração para a interoperabilidade de agentes baseados em distintos modelos de reputação. A idéia é usar essa ontologia como uma ontologia comum e global responsável 
pela integração semântica entre diferentes sistemas de reputação (CASARE e SICHMAN, 2005b);

- Incorporação da ontologia ao ambiente Agent Reputation and Trust (ART) Testbed (FULLAM et al., 2005), cujo objetivo é fornecer um meio comum para a experimentação e competição dos diversos sistemas de reputação. Esse ambiente, que foi proposto por um grupo de pesquisadores em reputação e confiança para SMA, deve fornecer ferramentas que permitam a comparação e a validação de modelos em domínios de aplicação comuns. 


\section{Referências Bibliográficas}

ALT, James E.; CALVERT, Randall L.; HUMES, Brian D. Reputation and Hegemonic Stability: A Game-Theoretic Analysis. In: The American Political Science Review, vol. 82, number 2 (june 1988), p. 445-466, 1988.

ARPÍREZ, J.C.; CORCHO, O.; FERNÁNDEZ-LÓPEZ, M.; GÓMEZ-PÉREZ, A. WebODE: a Scalable Workbench for Ontological Engineering. In: Proceedings of the First International Conference on Knowledge Capture (K-CAP 2001, Victoria, Canada, p. 6-13, 2001.

AXELROD, Robert. The Complexity of Cooperation: Agent-Based Models of Competition and Collaboration. Princeton Studies in Complexity. Princeton University Press, 1997.

BARBER, K. Suzanne; FULLAM, Karen; KIM, Joonoo. Challenges for Trust, Fraud and Deception Research in Multi-agent System. In: R. Falcone et al. (Eds.): Proceedings of the Workshop on Deception, Fraud and Trust, 1st International Joint Conference on Autonomous Agents and Multi-agent Systems (AAMAS 2002), LNAI 2631, p. 8-14, 2003.

BAUMEINSTER, Roy F. Self-esteem, self-presentation, and future interaction: A dilemma of reputation. In: Journal of Personality, vol. 50, number 1, p. 29-45, March 1982.

BAZZAN, Ana L. C.; BORDINI, Rafael H.; CAMPBELL, John A. Moral Sentiments in Multi-Agent Systems. In: P. Müller, M. P. Singh, and A. S. Rao (Eds.): Intelligent Agents V, Proceedings of ATAL-98, LNAI 1555, Springer-Verlag, p. 113-131, 1999.

BECHHOFER, S.; MOLLER, R.; CROWTHER, P. The DIG Description Logic Interface. In: Proceedings of the International Workshop on Description Logics - DL'03, 2003.

BERNERS-LEE, T.; HENDLER, J.; LASSILA, O. The Semantic Web. In: Scientific American, vol. 284, number 5, p. 28-37, 2001.

BRAY, T.; PAOLI, J.; SPERBERG-MCQUEEN, C.M.; MALER, E. Editors. Extensible Markup Language (XML) 1.0, Second Edition, World Wide Web Consortium. 2000. Disponivel em: <http://www.w3.org/TR/2000/REC-xml-20001006> - acessado em: 20/03/2005.

BROMLEY, Dennis Basil. Reputation, Image and Impression Management. John Wiley \& Sons Ltd. England, 1993.

CARBO, J.; MOLINA, J. M.; DAVILA, J. A Fuzzy Model of Reputation in Multi-Agent Systems. In: Proceedings of the Fifth International Conference on Autonomous agents (AGENTS’01), Montréal, Canada, p. 25-26, 2001. 
CARBO, J.; MOLINA, J. M.; DAVILA, J. Trust management through Fuzzy Reputation. In: International Journal of Cooperative Information System, vol. 12, number 1, p. 135155, 2003.

CARTER, Jonathan; BITTING Elijah; GHORBANI, A. Reputation Formalization For An Information - Sharing Multi-agent System. In: Computational Intelligence, vol. 18, number 2, p. 515-534, 2002.

CASARE, Sara; SICHMAN, Jaime Simão. Towards a Functional Ontology of Reputation. In: Proceedings of Fourth International Joint Conference on Autonomous Agents and Multi-agent Systems (AAMAS 2005), Utrecht, p. 505-511, 2005a .

CASARE, Sara; SICHMAN, Jaime Simão. Using a Functional Ontology of Reputation to Interoperate Different Agent Reputation Models. In: Journal of the Brazilian Computer Society - Special Issue on Ontologies Issues and Applications, vol. 11, number 2 (no prelo) 2005b.

CASTELFRANCHI, Cristiano; CONTE, Rosaria; PAOLUCCI, Mario. Normative reputation and the costs of compliance. In: Journal of Artificial Societies and Social Simulation vol. 1, number 3, 1998a.

CASTELFRANCHI, Cristiano; ROSIS, Florella; FALCONE, Rino; PIZZUTILO, Sebastiano. Personality Traits and Social Attitudes in Multiagent cooperation. In: Applied Artificial Intelligence, Journal, number 7/8; p. 649-675, 1998b.

CASTELFRANCHI, Cristiano; FALCONE, Rino; FIROZABADI, Babak Sadighi; TAN, Yao-Hua. $\quad$ Guest Editorial. In: Applied Artificial Intelligence Journal 14 (8), Special Issue on Trust, Deception and Fraud in Agent Societies, p. 763-768, 2000a.

CASTELFRANCHI, Cristiano; FALCONE, Rino; FIROZABADI, Babak Sadighi; TAN, Yao-Hua. $\quad$ Guest Editorial. In: Applied Artificial Intelligence Journal 14 (9), Special Issue on Trust, Deception and Fraud in Agent Societies, p. 863-865, 2000b.

CASTELFRANCHI, Cristiano; FALCONE, Rino. Social Trust: A Cognitive Approach. In: Castelfranchi C. and Yao-Hua Tan (Eds): Trust and Deception in Virtual Societes, Kluwer Academic Publishers, p. 55-90, 2001.

CASTELFRANCHI, Cristiano; FALCONE, Rino; PEZZULO, Giovanni. Trust in Information Sources as a Source for Trust: A Fuzzy Approach. In: Proceedings of Second International Joint Conference on Autonomous Agents and Multi-agent Systems (AAMAS'03), Melbourne, Australia, p. 89-96, 2003a.

CASTELFRANCHI, Cristiano; FALCONE, Rino; PEZZULO, Giovanni. Integrating Trustfulness and Decision Using Fuzzy Cognitive Maps. In: P. Nixon and S. Terzis (Eds.): Trust Management, LNCS 2692, Springer-Verlag Berlin Heidelberg, p. 195-210, 2003b.

CHAUI, Marilena. Convite à Filosofia. Editora Atlas. 13a. edição, 1999.

CHAVEZ, Anthony; MAES, Pattie. Kasbah: An Agent Marketplace for Buying and Selling Goods. In: Proceedings of the First International Conference on the Practical 
Application of Intelligent Agents and Multi-Agent Technology (PAAM'96). London, UK, April 1996.

CONTE, Rosaria; CASTELFRANCHI, Cristiano; DIGNUM, Frank. Autonomous Norm Acceptance. In: J.P. Müller et al. (Eds.): Agent Theories, Architectures, and Languages (ATAL-98), LNAI 1555, Springer-Verlag Berlin Heidelberg, p. 99-112, 1999.

CONTE, Rosaria; PAOLUCCI, Mario. Reputation in Artificial Societies: Social Beliefs for Social Order. Kluwer Academic Publishers. 2002.

CORCHO, Oscar; GOMEZ-PEREZ Asunción. A Roadmap to Ontology Specification Languages. In: Proceedings of the 12th European Workshop on Knowledge Acquisition, Modeling, and Management (EKAW' 00), France, p. 80-96, 2000.

CORCHO, Oscar; FERNANDEZ-LOPEZ, Mariano; GOMEZ-PEREZ Asunción. Methodologies, tools and languages for building ontologies: where is their meeting point? In: Data \& Knowledge Engineering, vol. 46, issue 1, p. 41-64, 2003.

DEAN, Mike; SCHREIBER, Guus. Editors. OWL Web Ontology Language Reference. W3C Recommendation, 10 February 2004. Disponível em: <http://www.w3.org/TR/2004/RECowl-ref-20040210/> - acessado em 20/04/2005.

DUPUY, Jean Pierre. Aux Origines des sciences cognitives. La decouverte, Paris, 1999.

FALCONE, Rino; PEZZULO, Giovanni; CASTELFRANCHI, Cristiano. A Fuzzy approach to a Belief-based Trust Computation. In: R. Falcone et al. (Eds.): Proceedings of the Workshop on Deception, Fraud and Trust, First International Joint Conference on Autonomous Agents and Multi-agent Systems (AAMAS 2002), LNAI 2631, p. 73-86, 2003.

FARQUHAR, A.; FIKES, R.; RICE, J. The Ontolingua Server: A Tool for Collaborative Ontology Construction. In: International Journal of Human-Computer Studies, vol. 46, number 6, p. 707-727, 1997.

FENSEL, D.; HORROCKS, I; VAN HARMELEN, F.; DECKER, S.; ERDMANN, M.; KLEIN, M. Oil in a Nutshell. In: Proceedings of the 12th European Workshop on Knowledge Acquisition, Modeling, and Management (EKAW' 00), France, p. 1-16, 2000.

FERNÁNDEZ-LÓPEZ, M.; GÓMEZ-PÉREZ, A.; JURINO, N. Methontology: From ontological art towards ontological engineering. In: Spring Symposium Series, Stanford, p. 33-40, 1997.

FERNÁNDEZ-LÓPEZ, M. Overview of Methodologies for Building Ontologies. In: Proceedings of the IJCAI-99 Workshop on Ontologies and Problem-Solving Methods, Stockholm, Sweden, 1999.

FERNÁNDEZ-LÓPEZ , M.; GÓMEZ-PÉREZ, A. The integration of OntoClean in WebODE. 2002. Disponível em: $<$ http://km.aifb.unikarlsruhe.de/eon2002/EON2002_Lopez.pdf> - acessado em 12/07/2004. 
FERREIRA, A. B. de H. Novo Dicionário Aurélio da Língua Portuguesa. Editora Nova Fronteira. 2a . Edição. 1986.

FERRIS, Gerald; BLASS, Fred; DOUGLAS, Ceasar; KOLODINSKY, Robert; TREADWAY, Darren. Personal Reputation in Organizations. In: GREENBERG, Jerald (Editor), Organizational Behavior - The State of the Science, LEA, New Jersey, p. 211246, 2003.

FULLAM, Karen K.; BARBER, Suzanne. A temporal Policy for Trusting Information. In: Proceedings of the Workshop on Trust in Agent Societies, Third International Joint Conference on Autonomous Agents and Multi-agent Systems (AAMAS 2004), p. 47-57, 2004.

FULLAM, Karen K.; KLOS, Tomas B.; MULLER, Guillaume; SABATER, Jordi; SCHLOSSER, Andreas; TOPOL, Zvi; BARBER, Suzanne; ROSENSCHEIN, Jeffrey S.; VERCOUTER, Laurent; VOSS, Marco. A specification of the Agent Reputation and Trust (ART) Testbed: Experimentation and Competition for Trust in Agent Societies. In: Proceedings of the Fourth International Joint Conference on Autonomous Agents and Multi-agent Systems (AAMAS 2005), p. 512-518, 2005.

GENNARI, J.; MUSEN, M.; FERGERSON, R.; GROSSO, W.; CRUBEZY, M.; ERIKSSON, H.; NOY, N.; TU, S. The evolution of Protégé: An Environment for Knowledge-Based Systems Development. In: International Journal of Human-Computer Studies, 58(1), p.89-123, 2003.

GENESERETH, M.; FIKES, R. Knowledge Interchange Format. Technical Report. Computer Science Departament. Stanford University. Logic 92-1. 1992.

GRUBER, Thomas R. Ontolingua: A mechanism to support portable ontologies. In: An Introduction to Software Agents. version 3.0, Technical Report, KSL 91-66, Knowledge Systems Laboratory, Department of Computer Science, Stanford University. 1992. Disponível em: <http://citeseer.ist.psu.edu/context/992998/0> - acessado em 19/04/2005.

GRUBER, Thomas R. Toward Principles for the Design of Ontologies Used for Knowledge Sharing. In: Nicola Guarino and Roberto Poli (Eds): Formal Ontology in Conceptual Analysis and Knowledge Representation, Kluwer Academic Publishers, 1994.

GUARINO, Nicola. Formal Ontology, conceptual analysis and knowledge representation. In: International Journal of Human and Computer Studies, 43(5/6), p. 625-640, 1995.

GUIZZARDI, Giancarlo; HERRE, Heinrich; WAGNER, Gerd. On the General Ontological Foundations of Conceptual Modeling. In: 21st International Conference on Conceptual Modeling (ER-2002), Tampere, Finland. Springer-Verlag, Berlin, Lecture Notes in Computer Science, (ISSN 0302-9743), p. 65-78, 2002.

HAARSLEV, V.; MOLLER, R. Racer: A core inference engine for the Semantic Web. In: Proceedings of the Second International Workshop on Evaluation of Ontology-based Tools (EON-2003), Sanibel Island, FL, 2003. 
HAARSLEV, V.; MOLLER, R. Racer User's Guide and Reference Manual - version 1.7.19. 2004. Disponível em: <http://www.sts.tu-harburg.de/ r.f.moeller/racer/> - acessado em $10 / 12 / 2004$.

HART, H. The concept of Law. Clarendon Law Press, Oxford University Press, 1961.

HASTORF, Albert; SCHNEIDER, David; POLEFKA, Judith. Percepção de Pessoa. Editora Edgard Blucher Ltda, 1973.

HORRIDGE, Matthew. A Practical Guide To Building OWL Ontologies With the ProtégéOWL Plugin. 2004. Disponível em:

$<$ http://protege.stanford.edu/plugins/owl/documentation.html $>$ - acessado em 22/07/2004.

HORROCKS, Ian. FaCT and iFact. In: Proceedings of the Description Logic. 1999.

Disponível em: <http://SunSITE.Informatik.RWTH-Aachen.DE/Publications/CEURWS/Vol-22/horrocks.ps> - acessado em 19/04/2005.

HORROCKS, I.; GOBLE, C.; STEVENS, R. OilEd: A Reasonable Ontology Editor for the Semantic Web. In: Proceedings of the Joint German/Austrian conference on Artificial Intelligence, Lecture Notes in Artificial Intelligence, vol. 2174, Springer, Berlin, p. 396408, 2001

HORROCKS, Ian. DAML+OIL: a Description Logic for the Semantic Web. In: Bulletin of the IEEE Computer Society Technical Committee on Data Engineering, 25(1), p. 4-9, 2002.

HUYNH, Dong; JENNINGS, Nicholas R.; SHADBOLT, Nigel R. Developing an Integrated Trust and Reputation Model for Open Multi-Agent Systems. In: Proceedings of the Workshop on Trust in Agent Societies, Third International Joint Conference on Autonomous Agents and Multi-agent Systems (AAMAS 2004), p. 65-74, 2004.

KELSEN, Hans. Teoria Geral da Normas. Editora Sergio Antônio Fabris, Porto Alegre, 1986.

KELSEN, Hans. Teoria pura do Direito. Editora Revista dos Tribunais, 2001.

KIFER, M.; LAUSEN, G.; WU, J. Logical Foundation of Object-Oriented and FrameBased Languages. In: Journal of the ACM, vol. 42, number 4, p. 741-843, 1995.

KLOS, Tomas; LA POUTRÉ, Han. Using Reputation-based Trust for Assessing Agent Reliability. In: Proceedings of the Workshop on Trust in Agent Societies, Third International Joint Conference on Autonomous Agents and Multi-agent Systems (AAMAS 2004), p. 75-82, 2004.

KLYNE, Graham; CARROLL, Jeremy J. Resource Description Framework (RDF): Concepts and Abstract Syntax. W3C Recommendation 10 February 2004. Disponível em: $<$ http://www.w3.org/TR/2004/REC-rdf-concepts-20040210/> - acessado em 20/04/2005.

KNUBLAUCH, Holger; FERGERSON, Ray W.; NOY, Natalya F.; MUSEN, Mark A. The Protégé OWL Plugin: An Open Development Environment for Semantic Web 
Applications. In: Proceedings of the Third International Semantic Web Conference (ISWC 2004), Hiroshima, Japan, p. 229-243, 2004.

KOSKO, Bart. Fuzzy Cognitive Maps. In: International Journal Man-Machine Studies vol. 24, p. 65-75, 1986.

MACGREGOR, R. Inside the LOOM classifier. In: SIGART bulletin, vol. 2, p. 70-76, 1991.

MAXIMILIEN, E. Michael; SINGH, Munindar P. Reputation and Endorsement for Web Services. In: SIGecom Exchanges, vol.3, number 1, p. 24-31, 2002a.

MAXIMILIEN, E. Michael; SINGH, Munindar P. Conceptual Model of Web Service Reputation. In: ACM SIGMOD Record, vol. 31, number 4, p. 36-41, December 2002b.

MCGUINNESS, Deborah; HARMELEN, Frank. Editors. OWL Web Ontology Language Overview. W3C Recommendation, 10 February 2004. Disponível em: <http://www.w3.org/TR/2004/REC-owl-overview-20040210/> - acessado em 20/04/2005.

MUI, Lik; HALBERSTADT, Ari; MOHTASHEMI, Mojdeh. Notions of Reputation in Multi-Agents Systems: A Review. In: Proceedings of 1st International Joint Conference on Autonomous Agents and Multi-agent Systems (AAMAS 2002), Bologna, Italy, p. 280287 2002a.

MUI, Lik; MOHTASHEMI, Mojdeh; HALBERSTADT, Ari. A Computational Model of Trust and Reputation. In: Proceedings of the 35th Hawaii International Conference on System Sciences, p. 188- 196, 2002b.

MUI, Lik; HALBERSTADT, Ari; MOHTASHEMI, Mojdeh. Evaluating Reputation in Multi-agents Systems. In: Proceedings of the Workshop on Trust, Reputation and Secutiry: Theories and Practice, First International Joint Conference on Autonomous Agents and Multi-agent Systems (AAMAS 2002), Springer-Verlag Berlin Heidelberg, p. 127-137, 2003.

OSTROM, Elinor. A behavioral Approach to the Rational Choice Theory of Collective Action: Presidential Address, American Political Science Association. In: The American Political Science Review, vol. 92, number 1, p.1-22, March 1998.

OSTROM, Elinor. Collective Action and the Evolution of Social Norms. In: The Journal of Economic Perspectives, vol. 14, number 3, p.137-158, 2000.

PARSIA, Bijan; SIRIN, Evren. Pellet: an OWL DL Reasoner. In: Proceedings of the Third International Semantic Web Conference (ISWC2004), 2004 - Disponível em: $<$ http://iswc2004.semanticweb.org/posters/PID-ZWSCSLQK-1090286232.pdf> - acessado em 19/04/05.

PUJOL, Josep M.; SANGÜESA, Ramon; DELGADO, Jordi. Extracting Reputation in Multi Agent Systems by Means of Social Network Topology. In: Proceedings of 1st International Joint Conference on Autonomous Agents and Multi-agent Systems (AAMAS 2002), Bologna, Italy, p. 467-474, 2002. 
RAO, A. S.; GEORGEFF, M. P. BDI agents: from theory to practice. In: LESSER, V. (Ed.): International Conference on MultiAgent Systems (ICMAS'95), 1, San Francisco, USA, p. 312-319, 1995.

RESNICK, Paul; ZECKHAUSER, Richard; FRIEDMAN, Eric; KUWABARA, K. Reputation Systems. In: Communications of the ACM, vol. 43, number 12, p. 45-48, December 2000.

ROUCHIER, Juliette; O’CONNOR, Martin; BOUSQUET, François. The creation of a reputation in an artificial society organised by a gift system. In: Journal of Artificial Societies and Social Simulation vol. 4, number 2, 2001. Disponível em: <http://www.soc.surrey.ac.uk/JASSS/4/2/8.html> - acessado em: 20/01/2004.

SABATER, Jordi. Trust and reputation for agent societies. PhD Thesis. Institut d'Investigacion en Intelligencia Artificial, Spain, 2003.

SABATER, Jordi; SIERRA, Carles. Review on Computational Trust and Reputation Models. In: Artificial Intelligence Review, vol. 24, number 1, 2005.

SEN, Sandip; SAJJA, Nesslima. Robustness of reputation-based trust: Boolean Case. In: Proceedings of 1st International Joint Conference on Autonomous Agents and Multi-agent Systems (AAMAS 2002), Bologna, Italy, p. 288-293, 2002.

SHENKAR, Oded; YUCHTMAN-YAAR, Ephraim. Reputation, Image, Prestige, and Goodwill: An Interdisciplinary Approach to Organizational Standing. In: Human Relations, vol. 50, number 11, p. 1361-1381, 1997.

SICHMAN, Jaime Simão. A dependence-Based Model for Social Reasoning in MultiAgent Systems. Boletim Técnico da Escola de Engenharia da USP, Departamento de Engenharia de Computação e Sistemas Digitais, BT/PCS/0108, 2001.

SMITH, Michael K.; WELTY, Chris; MCGUINNESS, Deborah, Editors. OWL Web Ontology Language Guide. W3C Recommendation, 10 February 2004. Disponível em: <http://www.w3.org/TR/2004/REC-owl-guide-20040210/> - acessado em 20/04/2005.

SU, Xiaomeng; ILEBREKKE; Lars. A Comparative Study of Ontology Languages and Tools. In: Proceeding of Conference on Advanced Information System Engineering (CAISE' 02). Toronto, Canada, Springer, 2002.

USCHOLD, Mike; GRUNINGER, Michael. Ontologies: Principles, Methods and Applications. In: Knowledge Engineering Review, vol. 11, number 2, p. 93-155, June 1996.

VALENTE, André. Legal Knowledge Engineering - A modeling Approach. IOS Press, Amsterdam, 1995.

VISSER, U.; STUCKENSCHMIDT, H.; WACHE, H.; VOGELE, T. Enabling technologies for interoperability. In: U. Visser and H. Pundt (Eds): Workshop on the 14th International Symposium of Computer Science for Environmental Protection, p. 35-46, 2000. 
W3C. World Wide Web Consortium. Disponível em: <http://www.w3.org/TR/owlguide/> - acessado em 26/07/2004.

WELTY, Cristopher; GUARINO, Nicola. Supporting ontological analysis of taxonomic relationship. In: Data and Knowledge Engineering, 39(1), p. 51-74, 2001.

YU, Bin; SINGH, Munindar P. An Evidential Model of Distributed Reputation Management. In: Proceedings of First International Joint Conference on Autonomous Agents and Multi-agent Systems (AAMAS 2002), Bologna, Italy, 2002.

YU, Bin; SINGH, Munindar P. Detecting Deception in Reputation Management. In: Proceedings of 2nd International Joint Conference on Autonomous Agents and Multi-agent Systems (AAMAS 2003), Melbourne, Australia, 2003.

ZACHARIA, Giorgos; MOUKAS, Alexandros; MAES, Pattie. Collaborative Reputation Mechanisms in Electronic Marketplaces. In: Proceedings of the 32nd Hawaii International Conference on System Sciences, 1999.

ZACHARIA, Giorgos; MAES, Pattie. Trust Management Through Reputation Mechanisms. In: Applied Artificial Intelligence, 14((9), Special Issue on Trust, Deception and Fraud in Agent Societies, p. 881-907, 2000. 


\section{Anexo A - Descrição do Conteúdo do CD}

Este anexo apresenta o conteúdo do CD que acompanha este trabalho.

Tal CD contém o executável dos dois softwares utilizados no desenvolvimento da Ontologia Funcional de Reputação, o Protégé e o RACER, bem como o documento em OWL DL e o projeto Protégé com a definição dos elementos que compõem esta ontologia. Além disso, este CD contém um arquivo com o procedimento a ser seguido para a instalação dos executáveis.

Este CD contém os seguintes arquivos, todos compatíveis com o sistema operacional Windows:

- Arquivo readme.doc, com a descrição do procedimento para a instalação do Protégé e do RACER;

- Arquivo install_protege.exe, com o código executável do ambiente de desenvolvimento de ontologias Protégé versão 2.1.2;

- Arquivo racer.exe, com o código executável do mecanismo de raciocínio automático RACER versão 1.7.23;

- Arquivo ReputationFunctionalOntology.pprj, com o projeto Protégé que contém a Ontologia Funcional de Reputação;

- Arquivo ReputationFunctionalOntology.owl, com o documento em OWL DL que contém a Ontologia Funcional de Reputação.

- Diretório docs, com material de apoio para uso do Protégé e RACER. 


\section{Anexo B - Tradução e Versão de Termos}

Este anexo apresenta a correspondência, em português e em inglês, dos nomes de classes e propriedades da Ontologia Funcional de Reputação.

A tabela 8.1 apresenta a tradução dos nomes de classes da Ontologia Funcional de Reputação, ou seja, o nome em inglês e seu corresponde em português, enquanto a tabela 8.2 apresenta a versão dos nomes das classes. Estas tabelas contêm os nomes das 84 classes que formam a ontologia, organizadas em ordem alfabética.

Tabela 8.1: Tradução dos nomes das classes da Ontologia Funcional de Reputação

\begin{tabular}{|l|l|}
\hline \multicolumn{1}{|c|}{ Nome da Classe em Inglês } & Nome da Classe em Português \\
\hline Activity & Atividade \\
\hline ActivityReputation & ReputaçãoAtividade \\
\hline ActorObservatorEffect & EfeitoAtorObservador \\
\hline AdequateStatus & StatusNormativoAdequado \\
\hline Agent & Agente \\
\hline AggregationProcess & ProcessoAgregaçãoReputação \\
\hline Attribution & AtribuiçãoDeCausalidade \\
\hline Case & Caso \\
\hline Circumstance & Circunstância \\
\hline CollectiveReputation & ReputaçãoColetiva \\
\hline CommumKnowledge & ConhecimentoDeSensoComum \\
\hline DirectExperience & ExperiênciaDireta \\
\hline DirectReputation & ReputaçãoDireta \\
\hline EvaluationAttributeWeight & RelevânciaAtributoAvaliaçãoReputação \\
\hline EvaluationFactor & FatorAvaliaçãoReputação \\
\hline EvaluatorRole & PapelAvaliador \\
\hline Event & Evento \\
\hline EventReputation & ReputaçãoEvento \\
\hline ExternalCause & CausaExterna \\
\hline Grouplnheritance & HerançaDeGrupo \\
\hline GroupOflndividual & GrupoDeIndividuos \\
\hline GroupReputation & ReputaçãoGrupo \\
\hline HistoricalProcess & ProcessoHistóricoReputação \\
\hline InadequateStatus & StatusNormativolnadequado \\
\hline Individual & Individuo \\
\hline IndividualReputation & Reputaçãolndividuo \\
\hline InformationSource & Fontelnformação \\
\hline InternalCause & Causalnterna \\
\hline Location & Local \\
\hline LocationReputation & ReputaçãoLocal \\
\hline MaintainerRole & PapelMantenedor \\
\hline NegativeSocialNorm & NormaSocialNegativa \\
\hline NeutralStatus & StatusNormativoNeutro \\
\hline & \\
\hline
\end{tabular}




\begin{tabular}{|c|c|}
\hline Nome da Classe em Inglês & Nome da Classe em Português \\
\hline NonAgent & NãoAgente \\
\hline NormativeKnowledge & ConhecimentoNormativo \\
\hline NormativeStatus & StatusNormativo \\
\hline Object & Objeto \\
\hline Observation & Observação \\
\hline ObservedReputation & ReputaçãoObservada \\
\hline PositiveSocialNorm & NormaSocialPositiva \\
\hline Prejudice & Preconceito \\
\hline PrimaryReputation & ReputaçãoPrimária \\
\hline ProductReputation & ReputaçãoProduto \\
\hline PropagatedReputation & ReputaçãoPropagada \\
\hline PropagationContent & ConteúdoDaPropagação \\
\hline PropagationForm & FormaPropagação \\
\hline PropagationPurpose & ObjetivoPropagação \\
\hline RecipientRole & PapelReceptor \\
\hline ReputationCalculationComponent & ComponenteCalculoReputação \\
\hline ReputationConcept & ConceitoReputativo \\
\hline ReputationContentEvaluationProcess & ProcessoAvaliaçãoConteúdoReputação \\
\hline ReputationEsteemLevelEvalaluationProcess & ProcessoAvaliaçãoNivelEstimaReputação \\
\hline ReputationEvaluationAttribute & AtributoAvaliaçãoReputação \\
\hline ReputationEvaluationProcess & ProcessoAvaliaçãoReputação \\
\hline ReputationEvaluationValue & ValorAvaliaçãoReputação \\
\hline ReputationFinalValue & ValorFinalReputação \\
\hline ReputationKnowledge & ConhecimentoDeReputação \\
\hline ReputationMaintenanceProcess & ProcessoManutençãoReputação \\
\hline ReputationNature & NaturezaReputação \\
\hline ReputationProcess & ProcessoReputativo \\
\hline ReputationPropagationComponent & ComponentePropagaçãoReputação \\
\hline ReputationProperty & PropriedadeReputação \\
\hline ReputationReceptionProcess & ProcessoRecepçãoReputação \\
\hline ReputationRelation & RelaçãoReputativa \\
\hline ReputationRole & PapelReputativo \\
\hline ReputationTransmissionProcess & ProcessoTransmissãoReputação \\
\hline ReputationType & TipoReputação \\
\hline ReputativeEntity & EntidadeReputativa \\
\hline ReputativeKnowledge & ConhecimentoReputativo \\
\hline ResponsibilityAssignment & ConfirmaçãoDeResponsabilidade \\
\hline ResponsibilityKnowledge & ConhecimentoDeResponsabilidade \\
\hline ResponsibilityRestriction & RestriçãoDeResponsabilidade \\
\hline SecondaryReputation & ReputaçãoSecundária \\
\hline SecondHandInformation & InformaçãoDeTerceiro \\
\hline Service & Serviço \\
\hline SocialNorm & NormaSocial \\
\hline StereotypedReputation & ReputaçãoAPriori \\
\hline TargetBehavior & ComportamentoAlvo \\
\hline TargetEvaluatorSocialRelation & RelaçãoSocial \\
\hline TargetRole & PapelAlvo \\
\hline Time & Tempo \\
\hline TransmitterReputation & ReputaçãoTransmissor \\
\hline TransmitterRole & PapelTransmissor \\
\hline WorldKnowledge & ConhecimentoDoMundo \\
\hline
\end{tabular}


Tabela 8.2: Versão dos nomes das classes da Ontologia Funcional de Reputação

\begin{tabular}{|c|c|}
\hline Nome da Classe em Português & Nome da Classe em Inglês \\
\hline Agente & Agent \\
\hline Atividade & Activity \\
\hline AtribuiçãoDeCausalidade & Attribution \\
\hline AtributoAvaliaçãoReputação & ReputationEvaluationAttribute \\
\hline Caso & Case \\
\hline CausaExterna & ExternalCause \\
\hline Causalnterna & InternalCause \\
\hline Circunstância & Circumstance \\
\hline ComponenteCalculoReputação & ReputationCalculationComponent \\
\hline ComponentePropagaçãoReputação & ReputationPropagationComponent \\
\hline ComportamentoAlvo & TargetBehavior \\
\hline ConceitoReputativo & ReputationConcept \\
\hline ConfirmaçãoDeResponsabilidade & ResponsibilityAssignment \\
\hline ConhecimentoDeReputação & ReputationKnowledge \\
\hline ConhecimentoDeResponsabilidade & ResponsibilityKnowledge \\
\hline ConhecimentoDeSensoComum & CommumKnowledge \\
\hline ConhecimentoDoMundo & WorldKnowledge \\
\hline ConhecimentoNormativo & NormativeKnowledge \\
\hline ConhecimentoReputativo & ReputativeKnowledge \\
\hline ConteúdoDaPropagação & PropagationContent \\
\hline EfeitoAtorObservador & ActorObservatorEffect \\
\hline EntidadeReputativa & ReputativeEntity \\
\hline Evento & Event \\
\hline ExperiênciaDireta & DirectExperience \\
\hline FatorAvaliaçãoReputação & EvaluationFactor \\
\hline Fontelnformação & InformationSource \\
\hline FormaPropagação & PropagationForm \\
\hline GrupoDelndividuos & GroupOfIndividual \\
\hline HerançaDeGrupo & Grouplnheritance \\
\hline Individuo & Individual \\
\hline InformaçãoDeTerceiro & SecondHandInformation \\
\hline Local & Location \\
\hline NãoAgente & NonAgent \\
\hline NaturezaReputação & ReputationNature \\
\hline NormaSocial & SocialNorm \\
\hline NormaSocialNegativa & NegativeSocialNorm \\
\hline NormaSocialPositiva & PositiveSocialNorm \\
\hline ObjetivoPropagação & PropagationPurpose \\
\hline Objeto & Object \\
\hline Observação & Observation \\
\hline PapelAlvo & TargetRole \\
\hline PapelAvaliador & EvaluatorRole \\
\hline PapelMantenedor & MaintainerRole \\
\hline PapelReceptor & RecipientRole \\
\hline PapelReputativo & ReputationRole \\
\hline PapelTransmissor & TransmitterRole \\
\hline Preconceito & Prejudice \\
\hline ProcessoAgregaçãoReputação & AggregationProcess \\
\hline ProcessoAvaliaçãoConteúdoReputação & ReputationContentEvaluationProcess \\
\hline ProcessoAvaliaçãoNivelEstimaReputação & ReputationEsteemLevelEvalaluationProcess \\
\hline
\end{tabular}




\begin{tabular}{|l|l|}
\hline \multicolumn{1}{|c|}{ Nome da Classe em Português } & \multicolumn{1}{c|}{ Nome da Classe em Inglês } \\
\hline ProcessoAvaliaçãoReputação & ReputationEvaluationProcess \\
\hline ProcessoHistóricoReputação & HistoricalProcess \\
\hline ProcessoManutençãoReputação & ReputationMaintenanceProcess \\
\hline ProcessoRecepçãoReputação & ReputationReceptionProcess \\
\hline ProcessoReputativo & ReputationProcess \\
\hline ProcessoTransmissãoReputação & ReputationTransmissionProcess \\
\hline PropriedadeReputação & ReputationProperty \\
\hline RelaçãoReputativa & ReputationRelation \\
\hline RelaçãoSocial & TargetEvaluatorSocialRelation \\
\hline RelevânciaAtributoAvaliaçãoReputação & EvaluationAttributeWeight \\
\hline ReputaçãoAPriori & StereotypedReputation \\
\hline ReputaçãoAtividade & ActivityReputation \\
\hline ReputaçãoColetiva & CollectiveReputation \\
\hline ReputaçãoDireta & DirectReputation \\
\hline ReputaçãoEvento & EventReputation \\
\hline ReputaçãoGrupo & GroupReputation \\
\hline ReputaçãoIndividuo & IndividualReputation \\
\hline ReputaçãoLocal & LocationReputation \\
\hline ReputaçãoObservada & ObservedReputation \\
\hline ReputaçãoPrimária & PrimaryReputation \\
\hline ReputaçãoProduto & ProductReputation \\
\hline ReputaçãoPropagada & PropagatedReputation \\
\hline ReputaçãoSecundária & SecondaryReputation \\
\hline ReputaçãoTransmissor & TransmitterReputation \\
\hline RestriçãoDeResponsabilidade & ResponsibilityRestriction \\
\hline Serviço & Service \\
\hline StatusNormativo & NormativeStatus \\
\hline StatusNormativoAdequado & AdequateStatus \\
\hline StatusNormativolnadequado & InadequateStatus \\
\hline StatusNormativoNeutro & NeutralStatus \\
\hline Tempo & Time \\
\hline TipoReputação & ReputationType \\
\hline ValorAvaliaçãoReputação & ReputationEvaluationValue \\
\hline ValorFinalReputação & ReputationFinalValue \\
\hline & \\
\hline
\end{tabular}

A tabela 8.3 apresenta os nomes das 44 propriedades da Ontologia Funcional de Reputação, em inglês e em português. A primeira e a segunda coluna contêm o nome da propriedade e da sua inversa em inglês, enquanto a terceira e a quarta coluna contêm os respectivos nomes em português. A primeira coluna apresenta os nomes organizados em ordem alfabética. 
Tabela 8.3: Nomes das propriedades da Ontologia Funcional de Reputação

\begin{tabular}{|c|c|c|c|}
\hline $\begin{array}{c}\text { Nome da } \\
\text { Propriedade em } \\
\text { Inglês }\end{array}$ & $\begin{array}{c}\text { Nome da } \\
\text { Propriedade } \\
\text { Inversa em } \\
\text { Inglês }\end{array}$ & $\begin{array}{l}\text { Nome da } \\
\text { Propriedade em } \\
\text { Português }\end{array}$ & $\begin{array}{c}\text { Nome da } \\
\text { Propriedade } \\
\text { Inversa em } \\
\text { Português }\end{array}$ \\
\hline hasAttribution & isAttributionOf & Tem atribuição & É atribuição de \\
\hline $\begin{array}{l}\text { hasBehaviorDescripti } \\
\text { onln }\end{array}$ & $\begin{array}{l}\text { isBehaviorDescription } \\
\text { Of }\end{array}$ & $\begin{array}{l}\text { Tem descrição de } \\
\text { comportamento }\end{array}$ & $\begin{array}{l}\text { É descrição de } \\
\text { comportamento }\end{array}$ \\
\hline hasClassificationFor & isClassifiedBy & Classifica & É classificado por \\
\hline $\begin{array}{l}\text { hasCorrespondence } \\
\text { With }\end{array}$ & isCorrespondentTo & $\begin{array}{l}\text { Tem correspondencia } \\
\text { com }\end{array}$ & Corresponde a \\
\hline hasDefinitionFor & isDefinedThrough & Tem definição para & É definido por \\
\hline hasDetailln & isDetailOf & Tem detalhe em & É detalhe de \\
\hline hasEffectOn & isEffectedBy & Tem efeito sobre & É afetada por \\
\hline hasImpactln & islmpactedFor & Tem impacto em & É influenciada por \\
\hline hasInformationSource & $\begin{array}{l}\text { isInformationSourceO } \\
f\end{array}$ & $\begin{array}{l}\text { Tem fonte de } \\
\text { informação em }\end{array}$ & É fonte de informação de \\
\hline hasInput & islnputOf & Tem entrada & É entrada para \\
\hline hasNormativeStatus & isNormativeStatusOf & Tem status norm & É status normativo de \\
\hline hasOccurredln & $\begin{array}{l}\text { isOccurrenceSituatio } \\
\mathrm{nFor}\end{array}$ & Ocorre em & É situação para \\
\hline hasOutput & isOutputOf & Produz & É produzido por \\
\hline $\begin{array}{l}\text { hasPropagationComp } \\
\text { onent }\end{array}$ & $\begin{array}{l}\text { isPropagationCompo } \\
\text { nentOf }\end{array}$ & Tem componentes em & É componente de \\
\hline hasProvoked & isProvokedBy & Provoca & É provocado por \\
\hline hasRelationFor & isRelatedThrough & $\begin{array}{l}\text { Tem relacionamento } \\
\text { para }\end{array}$ & É relacionado por \\
\hline hasReputation & isReputationOf & Tem reputação & É reputação de \\
\hline hasReputationNature & isReputationNatureOf & $\begin{array}{l}\text { Tem natureza de } \\
\text { reputação }\end{array}$ & $\begin{array}{l}\text { É natureza de reputação } \\
\text { de }\end{array}$ \\
\hline $\begin{array}{l}\text { hasReputationProces } \\
\mathrm{s}\end{array}$ & $\begin{array}{l}\text { isReputationProcess } \\
\text { Of }\end{array}$ & $\begin{array}{l}\text { Tem processo } \\
\text { reputativo }\end{array}$ & É processo reputativo de \\
\hline hasReputativeRole & isReputativeRoleOf & Tem papel reputativo & É papel reputativo de \\
\hline $\begin{array}{l}\text { hasResponsibilityAssi } \\
\text { gmentBy }\end{array}$ & $\begin{array}{l}\text { isResponsibilityAssig } \\
\text { nerFor }\end{array}$ & $\begin{array}{l}\text { Tem responsabilidade } \\
\text { confirmada por }\end{array}$ & Eesponsabilidade de \\
\hline hasWeight & isWeightOf & Tem relevância & É relevância de \\
\hline
\end{tabular}

